\title{
Abriendo Oportunidades: Guía Curricular Integrada 2015
}

\author{
Cecilia Garcés \\ Population Council \\ Paola Broll \\ Population Council
}

Follow this and additional works at: https://knowledgecommons.popcouncil.org/departments_sbsr-pgy

Part of the Civic and Community Engagement Commons, Family, Life Course, and Society Commons, and the Gender Equity in Education Commons How does access to this work benefit you? Let us know!

\section{Recommended Citation}

Cecilia Garcés and Paola Broll. 2015. "Abriendo Oportunidades: Guía Curricular Integrada 2015." Guatemala City: Population Council. 


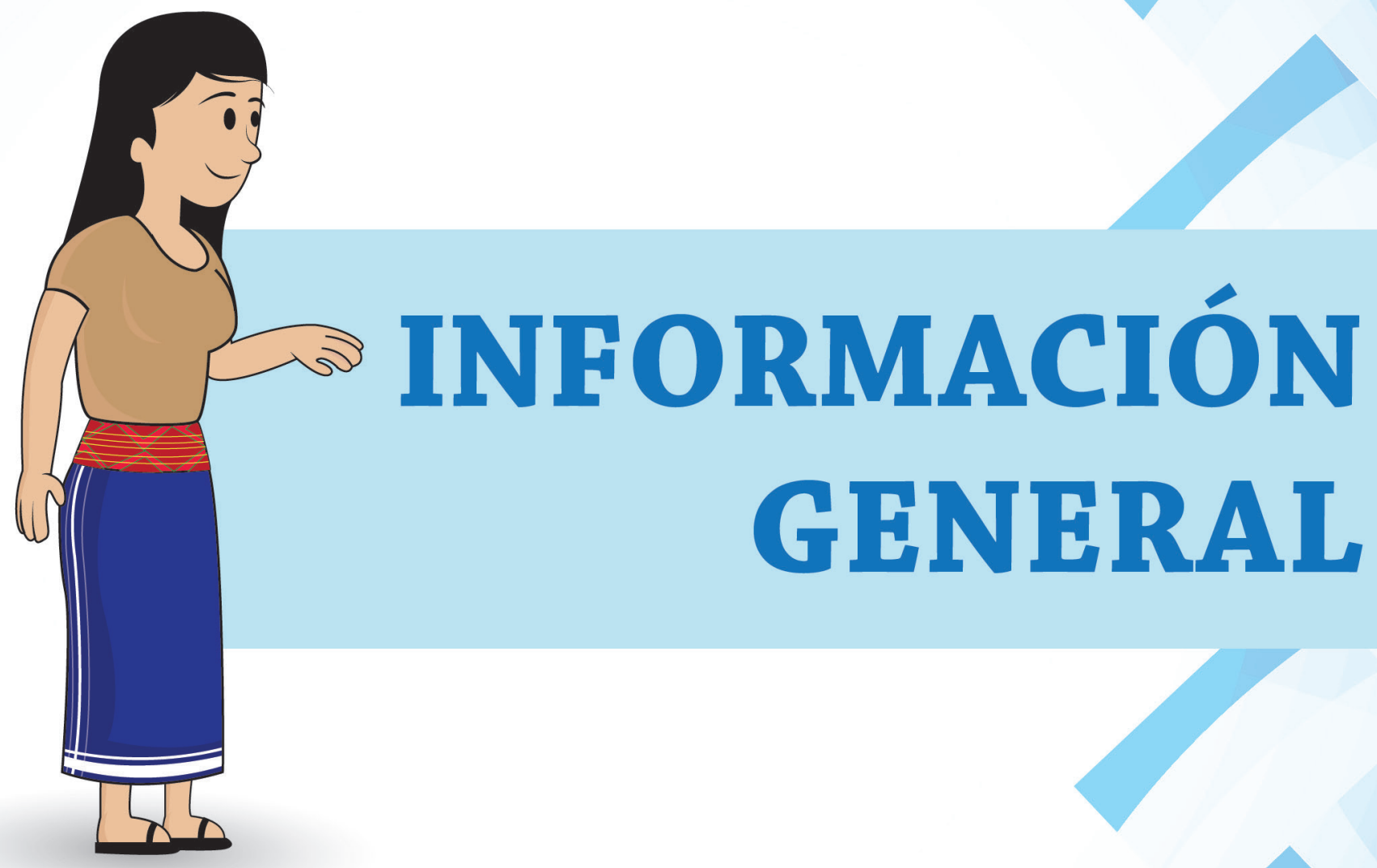

Guía Curricular Integrada 2015 - Population Council 


\section{Créditos}

\section{Autoras:}

María Cecilia Garcés de Marcilla/Especialista en Educación

$\checkmark$ Paola Broll / Oficial de Programa

- Revisión: Alejandra Munguía /Coordinador de Campo

- Diagramación: Isaí de la Cruz

- Equipo Population Council 2015:

- Directora de Programas: Alejandra Colom

- Supervisor de Monitoreo y Evaluación y oficial de Programa: Ángel del Valle

- Administradora: Ana Lucía Rodríguez

- Mentoras: Elizabeth Vásquez, Claudia Macz, Sonia Chó, Patricia Alva, Maribel Gutiérrez, Fabiola Colop, Rosa Güit 


\section{Contenido}

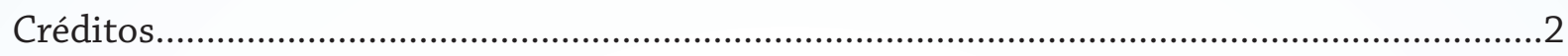

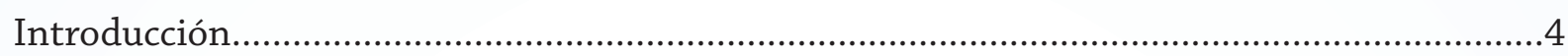

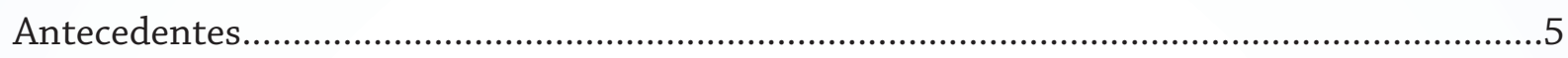

Educación desde el abordaje de los derechos humanos y de género.....................................6

Niñas y adolescentes:las protagonistas del proceso.......................................................

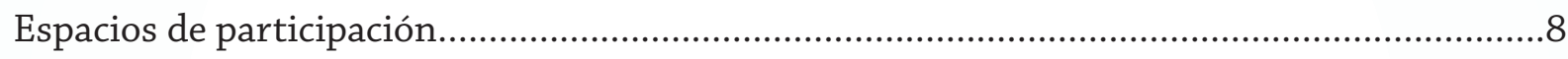

Niñas y adolescentes participantes en los grupos......................................................... 8

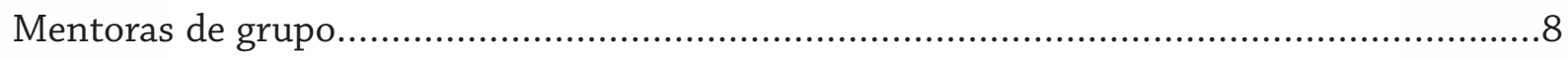

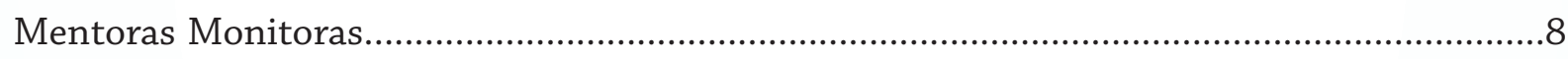

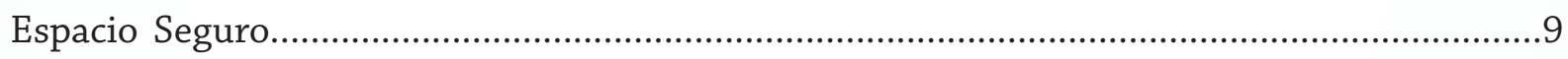

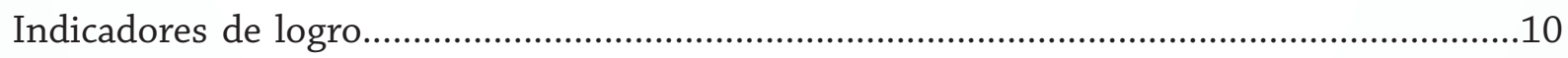

Estructura de la guía curricular.............................................................................11

Cronograma y dosificación de temas según edad ...........................................................13

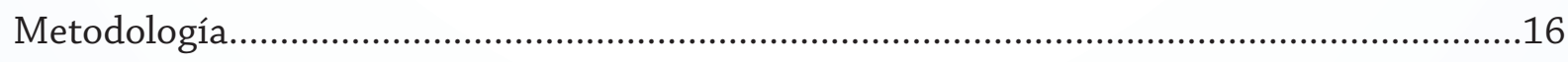

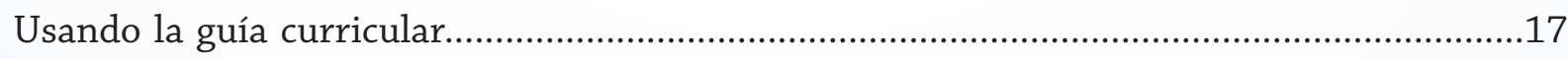




\section{Introducción}

Population Council Es una organización no gubernamental internacional, con sede en Nueva York. Desarrolla programas con niñas adolescentes en 14 países del mundo en tres continentes (África, Asia y América Latina). En Guatemala tiene más de 12 años de existir. Su actividad central es el desarrollo de investigaciones que permiten comprender las problemáticas que viven diversas poblaciones alrededor del mundo, con un enfoque particular en niñas, jóvenes y personas que viven en condición de pobreza.

Las investigaciones demuestran que las niñas adolescentes, en condiciones de pobreza y viviendo en áreas rurales de Guatemala tienden a dejar de ir a la escuela alrededor de los 12 años. Entre otras causas, porque sus familias priorizan la inversión en sus pares hombres, no hay escuelas en el área y porque ante la falta de opor-tunidades se entiende que es más útil que las jóvenes empiezan su vida como madres de familia. El abandono escolar las hace más vulnerables de riesgos como la migración forzada, los embarazos a temprana edad y la violencia en su círculo cercano.

Con base en la evidencia, el Population Council, diseñó el programa centrado en niñas adolescentes: Abriendo Oportunidades, con el propósito de fortalecer la transición hacia la adolescencia e incrementae su promoción y retención escolar. El programa se ha sostenido por más de diez años alcanzando a más de 8000 niñas adolescentes en el país, trabajando con las comunidades para fortalecer la capacidad de estudio, las habilidades de trabajo, el liderazgo y el bienestar de las niñas y adolescentes.

Para dar inicio se consensúa con las autoridades comunitarias la apertura del programa mediante la firma de un contrato comunitario, la realización de un mapeo comunitario que permite identificar y caracterizar a la población de niñas adolescentes y la provisión de un espacio seguro. Se convoca a todas a participar en sesiones semanales que se realizan en el espacio seguro donde son recibidas por una mujer joven de una comunidad cercana, a quien se le conoce como mentora, quien está preparada para liderar a las niñas adoles-centes en actividades que les permitirán el aprendizaje de nuevos conocimientos y desarrollar activos para la convivencia, la prevención de violencia y el desarrollo de su autonomía. Las sesiones semanales se desarrollan en base a las actividades y temáticas propuestas en esta guía curricular.

La guía se desarrolla con base en tres ejes transversales: 1. Derechos humanos, 2. Género y 3. Pertinencia. Presenta 6 módulos de trabajo con una duración aproximada de 3 meses cada uno para alcanzar los 18 meses que permiten el desarrollo de los activos establecidos como objetivos. Más de una década de trabajo demues-tra que las niñas adolescentes participantes en el programa se mantienen en la escuela, pierden el miedo de participar, aumentan su autoestima, aprenden nuevas habilidades, desarrollan una red de apoyo comunitaria. Se ha evidenciado también que cuando la comunidad y las familias invierten en las niñas ellas se motivan a estudiar, apoyan a la comunidad, aspiran a tener mejores trabajos.

Ellas y sus familias son más saludables y felices. 


\section{Antecedentes}

En 2004, el Population Council lanzó el programa Abriendo Oportunidades, con el propósito de apoyar a las niñas mayas guatemaltecas en el alcance de su potencial máximo para romper el círculo de la pobreza. (Catino, Colom, \& Ruiz, 2011) Durante estos 10 años se han acumulado lecciones valiosas muchas veces aportadas por las mismas jóvenes que lideran el programa en sus comunidades. El diálogo constante de todo el equipo de trabajo ha permitido contar hoy con la presente versión. Ésta es valiosa para la prevención de violencia basada en género, la educación en derechos humanos y la educación integral en sexualidad.

Las primeras dos versiones de la guía curricular enfocaron temas fundamentalmente centrados en la salud reproductiva, nutrición, higiene, comunicación, educación financiera. Varios de los temas iniciales así como algunas actividades están presentes en la guía hoy. Su implementación se desarrollaba en módulos a través de dos tomos que buscaban atender diversos grupos de edad. Su implementación hizo evidente la necesidad de incluir nuevos temas, establecer los ejes transversales y fortalecer la metodología de trabajo.

En 2012 se realizó una revisión y adaptación a la guía curricular que ha derivado en lo que hoy aquí se presenta. De forma participativa el equipo del Council, las jóvenes mentoras y especialistas en educación se propusieron adaptar la guía a las condiciones de vida de niñas adolescentes indígenas del área rural guatemalteca, se diseñó una nueva estructura temática, temporal y metodológica.

Para ello se trabajó desde la perspectiva de género, el abordaje de derechos humanos y la interculturalidad como ejes transversales a todas las temáticas presentadas. Se agregó educación financiera, se profundizó sobre los derechos sexuales y los derechos reproductivos, la prevención de violencia y los derechos de grupos específicos (mujeres, niñez y juventud y pueblos indígenas). En sintonía, se creó el programa de fortalecimiento y acompañamiento docente para mentoras. La guía se perfiló entre el equipo como una herramienta para fomentar la reflexión, el diálogo, la sororidad y el pensamiento crítico. Es reconocida como valiosa herramienta para la educación integral en sexualidad y la prevención de violencia. 
Educación desde el abordaje

de los derechos humanos y de género

La guía curricular se fundamenta en la perspectiva de los derechos humanos y la equidad de género. respetando y promoviendo los siguientes principios:

Todas las niñas adolescentes son ciudadanas.

Los derechos humanos son condiciones minimas de vida de las que todos y todas debemos gozar y conocer.

El Estado está comprometido a garantizar los derechos humanos por ley.

Todo tipo de violencia es un problema social, comunitario y familiar, inaceptable que se ha de erradicar.

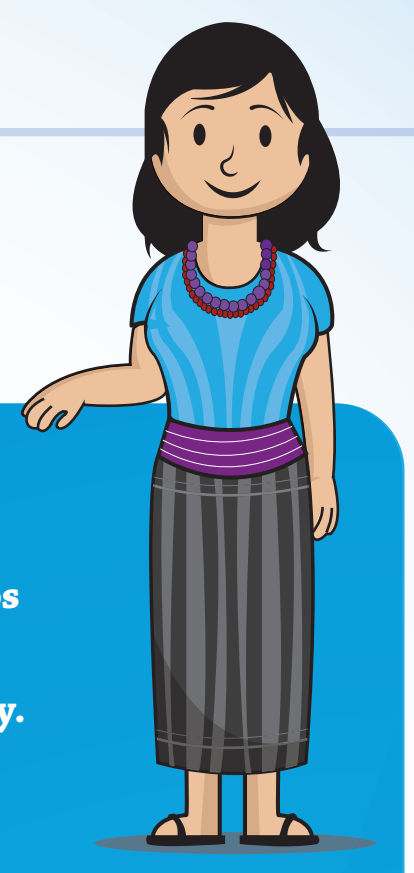

Las condiciones de desventaja en la que viven las niñas adolescentes y las mujeres no son naturales. Es posible y necesario actuar en comunidad para modificarlas.

La educación, la nutrición, la salud y el acceso a recursos fortalecen la autonomía de las mujeres para mejorar su vida, la de su familia y su comunidad.

El trabajo organizado y participativo de todas las personas de la comunidad es valioso y tiene la posibilidad de fomentar la equidad entre la población.

Las niñas adolescentes tienen la capacidad y el derecho de participar como lideresas en su familia y comunidad

Abriendo Oportunidades pone a las niñas adolescentes en el centro y fundamenta su modelo educativo en la educación de calidad cuidando que incorpore a las más vulnerables, cuente con la inversión de la comunidad, fomente la equidad, ofrezca formación significativa y relevante que responde al contexto y la cultura de las participantes. De esta manera se fortalece el derecho a la educación y se abre la puerta a el cumplimiento de otros derechos humanos. Los resultados de este abordaje integral se muestran manifiestan al cabo de unos 18 meses en niñas adolescentes con mejor autoestima que se animan a participar como ciudadanas en el cumplimiento de sus derechos. 


\section{Niñas y adolescentes: las protagonistas del proceso}

En todo el mundo las niñas adolescentes originarias de pueblos indígenas afrontan mayores desventajas que sus pares, por sufrir discriminación fundamentada en una visión adulto céntrica, patriarcal y racista. Con limitadas oportunidades educativas, nutricionales y económicas presentan altos índices de maternidad precoz, mortalidad materna, uniones tempranas y violaciones a sus derechos humanos.

Los datos manifiestan las difíciles condiciones de vida de niñas adolescentes indígenas en Guatemala:

$\mathbf{8 1 \%}$ vive en condiciones de pobreza.

Dos de cada tres vive en áreas rurales en donde carecen de servicios básicos.

En el área rural, las niñas completan $\mathbf{1 . 2}$ años promedio de escolaridad.

A los 17 años el $\mathbf{2 6 \%}$ se mantiene en el sistema escolar.

$69 \%$ es analfabeta y el $31 \%$ participa en el mercado laboral.

$40 \%$ inicia unión con una pareja antes de los 18 años.

$54 \%$ tendrán un hijo o hija antes de los 20 años.

$25 \%$ de todos los embarazos corresponden a niñas de entre 10 a 19 años.

Unicef 2008, Unicef 2009, Hallman et.al. 2007, Sewal-Menon y otros 2012, ICEFI Y UNICEF 2013

La transición entre el período de la niñez y la juventud/adultez, es cuando más frecuentemente las niñas abandonan la vida escolar e inician su vida como esposas y/o madres. La evidencia demuestra que las niñas mayas viviendo en pobreza extrema muestran altos niveles de deserción escolar a partir de los 12 años, y además escasamente han logrado completar la educación primaria. Las niñas y mujeres manifiestan que las tareas domésticas y la limitante económica son las principales causas por las que ya no se sigue en la escuela. Debido a la expectativa familiar de que las niñas continúen su desarrollo dentro del trabajo del ámbito doméstico, no se suele invertir en su educación, luego de la pubertad. (Catino, Hallman, Peracca, \& Ruiz, 2006) El relacionamiento entre adolescentes de ambos sexos representa una preocupación de tal envergadura que es una limitante en la presencia de las adolescentes en el sistema escolar y la participación. (Colom et al., 2004).

Revertir esta situación requiere acciones de atención específica centrada en sus necesidades particulares, que ofrezcan espacios seguros para consolidar su red social de amigas, destrezas básicas para la vida, educación en derechos humanos y habilidades financieras. Enfatizar en este grupo de población es necesario para alcanzarlas y apoyar sus necesidades. (Sewall-Menon, y otros, 2012) A pesar de ello, investigaciones de Population Council determinaron que estas niñas tienen acceso a solo unos pocos programas sociales. (Catino, Colom, \& Ruiz, 2011) Es por todo lo anterior que el Programa Abriendo Oportunidades en Guatemala se ha enfocado en niñas y adolescentes indígenas de entre 8 a 17 años que viven en comunidades rurales del país cuya población está inmersa en condiciones de pobreza. De este grupo, busca alcanzar especialmente aquellas niñas "invisibles" las que no estudian en la escuela, no salen de casa y cuyos derechos son más vulnerados. 


\section{Espacios de participación}

La estructura participativa de Abriendo Oportunidades se caracteriza por ser un modelo de liderazgo en cascada a nivel comunitario y municipal. Participan en él niñas y adolescentes en tres roles y niveles:

\section{A. Niñas y adolescentes}

Agrupadas según su edad las niñas adolescentes se encuentran una vez a la semana en el espacio seguro junto a su mentora para realizar tres principales tipos de actividades:

\section{Manualidades, 2. Juegos de convivencia y 3. Estudio de temas.}

La asistencia al grupo es gratuita y libre, no hay más requisitos que el ser niña adolescente. A las niñas se les convoca mediante asambleas comunitarias y visitas domiciliares. Paulatinamente las niñas aumentan su red de amigas y habilidades de relacionamiento de pares, desarrollan nuevas competencias, participan y dialogan para fortalecer su sentido crítico.

\section{B. Mentoras comunitarias}

Son mujeres jóvenes provenientes de las mismas comunidades de las niñas adolescentes participantes, que lideran las sesiones a la vez que inciden ante las autoridades comunitarias para mantener su apoyo en los espacios seguros. El perfil de las mentoras comunitarias incluye:

- Mujeres indígenas jóvenes de comunidades rurales

- Graduadas de diversificado

- Leer y escribir en español y la lengua materna de la localidad

Estas jóvenes realizan mentorías y se constituyen en un referente para las niñas adolescentes a la vez que se integran a su red social de apoyo.

Con el fin de apoyar a la mentora comunitaria en su desarrollo ella participa en el Componente de Formación Docente, se incorpora al mapeo y educación en derechos humanos, salud sexual, salud reproductiva e incidencia política.

\section{C.Mentoras Monitoras}

Las mentoras monitoras son mujeres jóvenes del municipio o departamento de intervención que acompaña a las mentoras comunitarias en su desarrollo. Ellas son motivadas a continuar estudiando para alcanzar mayor autonomía en su vida. Visitan a las mentoras comunitarias para ofrecerles retroalimentación en el marco del proceso de fortalecimiento docente.

También participan en reuniones con líderes y lideresas de la comunidad para gestionar el apoyo que pueda necesitarse en el espacio seguro.
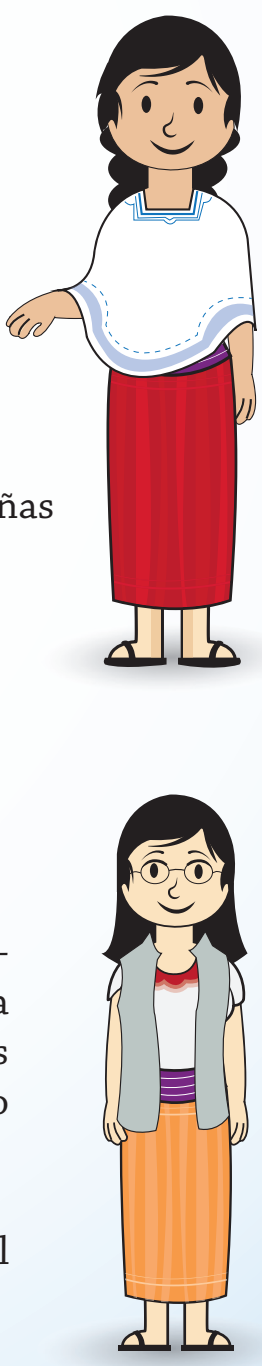


\section{Espacio Seguro}

El programa Abriendo Oportunidades requiere que la comunidad provea de un lugar público a las niñas adolescentes para sus reuniones. A éste se le reconoce como el lugar en el que se creará el espacio seguro; constituido por elementos como la disposición física y el entorno; pero principalmente por la relación de respeto y cuidado que se construye entre quienes se encuentran allí. Son espacios seguros los lugares en los que las niñas adolescentes (...) gozan de mayor autonomía y movilidad en la comunidad (...), desarrollan habilidades profesionales y de liderazgo, y planes más ambiciosos para su educación y sus vidas, lo que genera más respeto por parte de sus propias familias y comunidades. (Catino, Colom, \& Ruiz, Preparación de las niñas mayas para mejorar su calidad de vida, 2011)

Para aprender es importante que tengan la oportunidad de equivocarse, de ser auténticas, de comunicarse a profundidad. Por lo anterior es crítico fomentar un ambiente seguro donde las participantes pueden comunicarse sin ser juzgadas. El espacio seguro ofrece la oportunidad de fomentar la sororidad; que las niñas se relacionen en base a los puntos que les unen para generar apoyo.

\section{Indicadores de logro}

Las niñas adolescentes que participan en el programa valoran positivamente sus habilidades, adquieren conocimientos importantes para su vida diaria y establecen un plan de vida, cambian la forma en que les percibe su comunidad, su familia y sus pares. Su comprensión acerca de la pobreza cambia y muchas empiezan a ver hacia el futuro articulando su plan de vida. (Catino, Colom, \& Ruiz, 2011)

Antes, ellos [nuestros padres] le permitían a mi hermano estudiar, porque era varón, digamos, pero no a mí. Pero ahora, he demostrado -creo que les he demostrado a mis padres- que puedo hacerlo. Porque antes... mi padre me decía que cuando terminara sexto [grado], "no vas a estudiar", y así era. Pero cuando este proyecto comenzó, me dieron la oportunidad de estudiar y ahora tengo mis metas y quiero graduarme. Quiero seguir estudiando. - Joven líder, Sololá (Catino, Colom, \& Ruiz, Preparación de las niñas mayas para mejorar su calidad de vida, 2011)

Las participantes manifiestan que son cuatro los logros más valiosos en sus vidas.

\section{Aumenta su autoestima}

2. Pierden el miedo de participar

3. Aumenta su red de amigas

4. su conocimiento sobre salud sexual y reproductiva.

Es posible evaluar el alcance de estos logros mediante los indicadores establecidos en la siguiente tabla: 

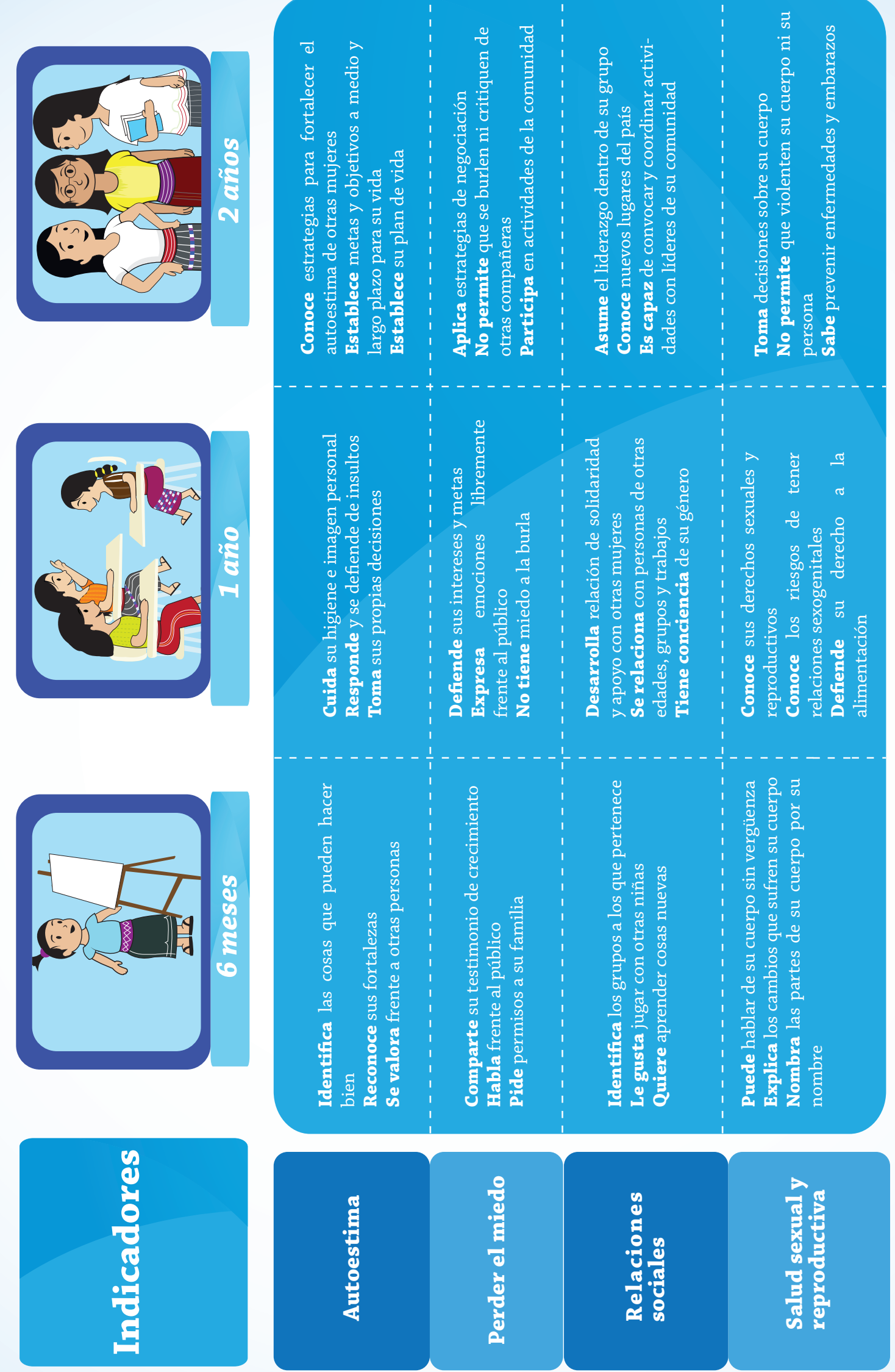


\section{Estructura de la guía curricular}

La guía curricular está conformada por ocho dominios que se consolidan el abordaje de derechos humanos, la perspectiva de género y la interculturalidad. De estos ocho, se desprende cada una de las sesiones de trabajo, por medio de las cuales las niñas adolescentes desarrollan competencias en las que:

\section{Abriendo Oportunidades:}

trabajan el concepto de espacios seguros, la relación que tienen las mujeres con los lugares y la posibilidad de prevenir la violencia.

\section{Fortalecimiento personal:}

reflexionan en torno a la identidad, la autoestima, las destrezas de relacionamiento y su plan de vida.

\section{Proyección comunitaria:}

identifican sus fortalezas para servir y trabajar en el desarrollo humano de la comunidad.

\section{Salud:}

conocen datos sobre nutrición, salud de la mujer y prevención de enfermedades.

\section{Salud sexual y reproductiva:}

conocen en detalle acerca de la menstruación, las relaciones de noviazgo y la planificación familiar.

\section{Educación financiera:}

identifican su participación en la economía, la administración de recursos y las responsabilidades ciudadanas.

\section{Prevención de la violencia:}

reconocen tipos de violencia, conocen instrumentos legales y desarrollan estrategias para su prevención.

\section{Género:}

Conocen la diferencia entre el género y el sexo para identificar aquellas prácticas, ideas y costumbres que marcan el acceso a oportunidades para su desarrollo.

Los ocho dominios se trabajan de forma intercalada en seis módulos que duran aproximadamente tres meses cada uno mediante las sesiones semanales de encuentro.

La totalidad de sesiones se implementan en aproximadamente 18 meses organizados de la siguiente manera: 


\begin{tabular}{|l|}
\hline Módulo I (mes 1-3) \\
\hline Anriendo Oportunidades
\end{tabular}




\section{Cronograma de sesiones y dosificación de temas según edad}

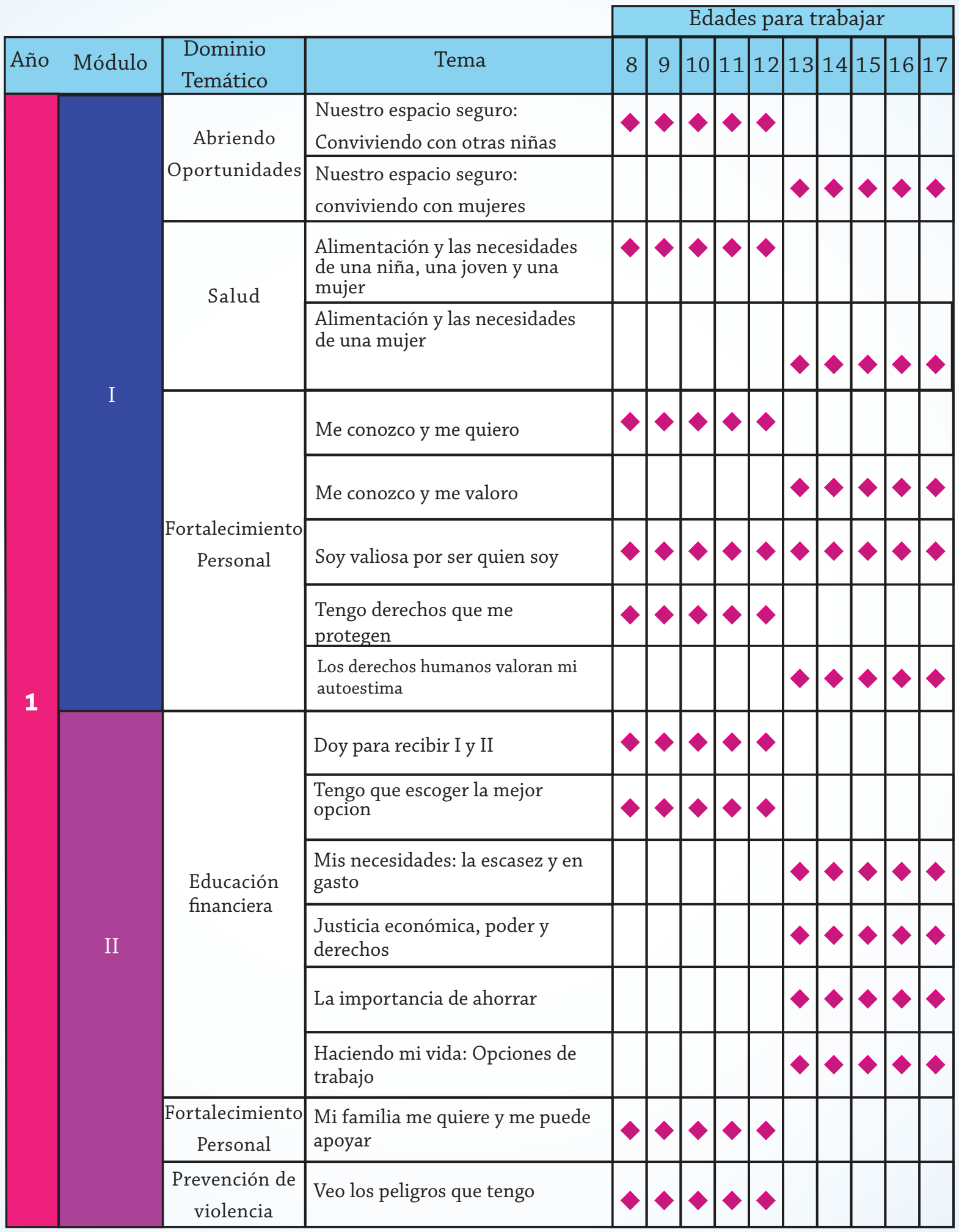




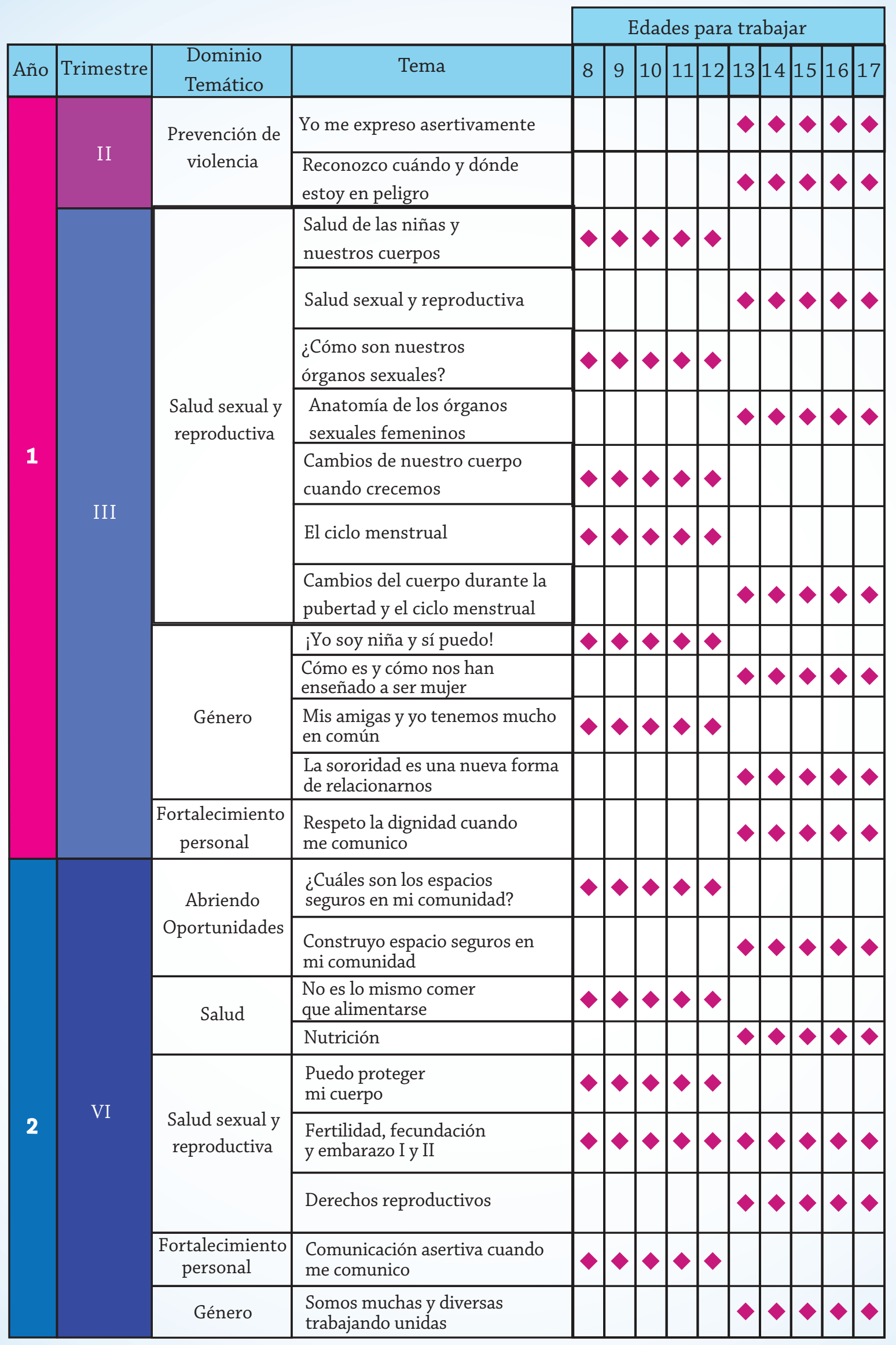




\begin{tabular}{|c|c|c|c|c|c|c|c|c|c|c|c|c|c|}
\hline Año & Trimestre & $\begin{array}{l}\text { Dominio } \\
\text { Temátice } \\
\end{array}$ & Tema & 8 & 9 & 10 & 11 & 12 & 13 & 14 & 15 & 16 & 17 \\
\hline \multirow{20}{*}{2} & \multirow{10}{*}{ V } & \multirow{4}{*}{$\begin{array}{l}\text { Educación } \\
\text { financiera }\end{array}$} & Aprendo a comprar I y II & $>$ & $>$ & $>$ & $>$ & $>$ & & & & & \\
\hline & & & $\begin{array}{l}\text { ¿Quién paga y cómo se } \\
\text { distribuyen los servicios } \\
\text { públicos que recibimos? }\end{array}$ & & & & & & $\diamond$ & 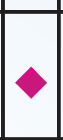 & $\diamond$ & $>$ & $>$ \\
\hline & & & Ahorro para estar bien I y II & $\diamond$ & $>$ & $>$ & $>$ & $\diamond$ & & & & & \\
\hline & & & $\begin{array}{l}\text { El crédito un asunto de } \\
\text { responsabilidad }\end{array}$ & & & & & & $\diamond$ & $>$ & $\diamond$ & 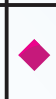 & $>$ \\
\hline & & \multirow{4}{*}{$\begin{array}{l}\text { Prevención de } \\
\text { violencia }\end{array}$} & $\begin{array}{l}\text { Puedo decidir para } \\
\text { protegerme }\end{array}$ & $\diamond$ & $\diamond$ & $>$ & 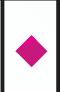 & $>$ & & & & & \\
\hline & & & $\begin{array}{l}\text { Cambiando la violencia por el } \\
\text { respeto entre hombres y } \\
\text { mujeres }\end{array}$ & 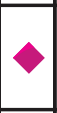 & $\diamond$ & $>$ & $>$ & $>$ & & & & & \\
\hline & & & $\begin{array}{l}\text { Vencemos obstáculos en esta } \\
\text { comunidad }\end{array}$ & & & & & & $\diamond$ & $\bullet$ & $\bullet$ & 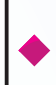 & 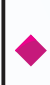 \\
\hline & & & $\begin{array}{l}\text { La violencia se combate con } \\
\text { valor, inteligencia y nuestras } \\
\text { amigas }\end{array}$ & & & & & & $\diamond$ & $>$ & $\diamond$ & 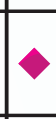 & $\nabla$ \\
\hline & & \multirow{2}{*}{$\begin{array}{l}\text { Proyección } \\
\text { comunitaria }\end{array}$} & Vernos de frente & & & & & & $\diamond$ & $\bullet$ & $\diamond$ & 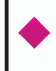 & $\gamma$ \\
\hline & & & $\begin{array}{l}\text { Las necesidades de mi } \\
\text { comunidad }\end{array}$ & & & & & & $\diamond$ & $\bullet$ & $\bullet$ & $\diamond$ & $\diamond$ \\
\hline & \multirow{10}{*}{$V I$} & \multirow{3}{*}{$\begin{array}{l}\text { Salud sexual y } \\
\text { reproductiva }\end{array}$} & $\begin{array}{l}\text { En mis relaciones de novi- } \\
\text { azgo yo decido }\end{array}$ & & & & & & $\diamond$ & $\diamond$ & $\bullet$ & $\diamond$ & $\nabla$ \\
\hline & & & $\begin{array}{l}\text { Informándome sobre ITS y } \\
\text { VIH/SIDA }\end{array}$ & & & & & & 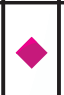 & $\bullet$ & $\bullet$ & $>$ & $\diamond$ \\
\hline & & & $\begin{array}{l}\text { Planificación } \\
\text { familiar }\end{array}$ & & & & & & $\diamond$ & 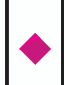 & 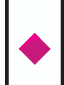 & 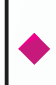 & $>$ \\
\hline & & \multirow{7}{*}{$\begin{array}{l}\text { Proyección } \\
\text { comunitaria }\end{array}$} & $\begin{array}{l}\text { Derechos de las niñas de } \\
\text { mi comunidad }\end{array}$ & $\diamond$ & $\diamond$ & $\diamond$ & $\diamond$ & $>$ & & & & & \\
\hline & & & $\begin{array}{l}\text { Mujeres adultas que admiro } \\
\text { por su trabajo }\end{array}$ & $\diamond$ & $\diamond$ & $\diamond$ & 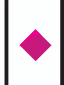 & $\diamond$ & & & & & \\
\hline & & & $\begin{array}{l}\text { Las necesidades de mi comu- } \\
\text { nidad }\end{array}$ & $\diamond$ & $\diamond$ & $\diamond$ & 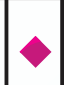 & $\diamond$ & & & & & \\
\hline & & & $\begin{array}{l}\text { Imagino lo que puedo alcanzar } \\
\text { en mi vida }\end{array}$ & $\diamond$ & $\diamond$ & 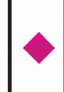 & $\diamond$ & $\diamond$ & & & & & \\
\hline & & & Mi regalo para la comunidad & 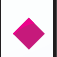 & $>$ & $>$ & $>$ & $\nabla$ & & & & & \\
\hline & & & $\begin{array}{l}\text { Soy un aporte para el } \\
\text { desarrollo }\end{array}$ & & & & & & 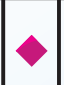 & $\diamond$ & $\diamond$ & $\diamond$ & $\nabla$ \\
\hline & & & Mi aporte a la comunidad & & & & & & $\diamond$ & $\bullet$ & $\diamond$ & 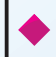 & $\nabla$ \\
\hline
\end{tabular}




\section{Metodología}

En este programa se reflexiona sobre la propia vida, se identifican las causas de los problemas y se fortalecen las capacidades para mejorar y hacer crecer a la comunidad. Se aprende mejor cuando se hace en confianza, entre pares, unas de otras. Esto pasa cuando hay relaciones de respeto y aprecio entre la mentora de grupo, y las niñas y jóvenes participantes, por lo que es fundamental que sientan la comodidad para participar, compartir y dialogar. (Garcés, 2013)

La metodología se fundamenta en la educación liberadora y la educación popular, por lo que en cada sesión se ofrece espacio para partir de las experiencias de las participantes y su comprensión de los eventos por medio de los nuevos conocimientos. Esta metodología desarrolla técnicas de facilitación y dinámicas que decisiones propiciando cambios significativos en su entorno personal, familiar y comunitario que les permita ser agentes de cambio. Las técnicas de facilitación incluyen:

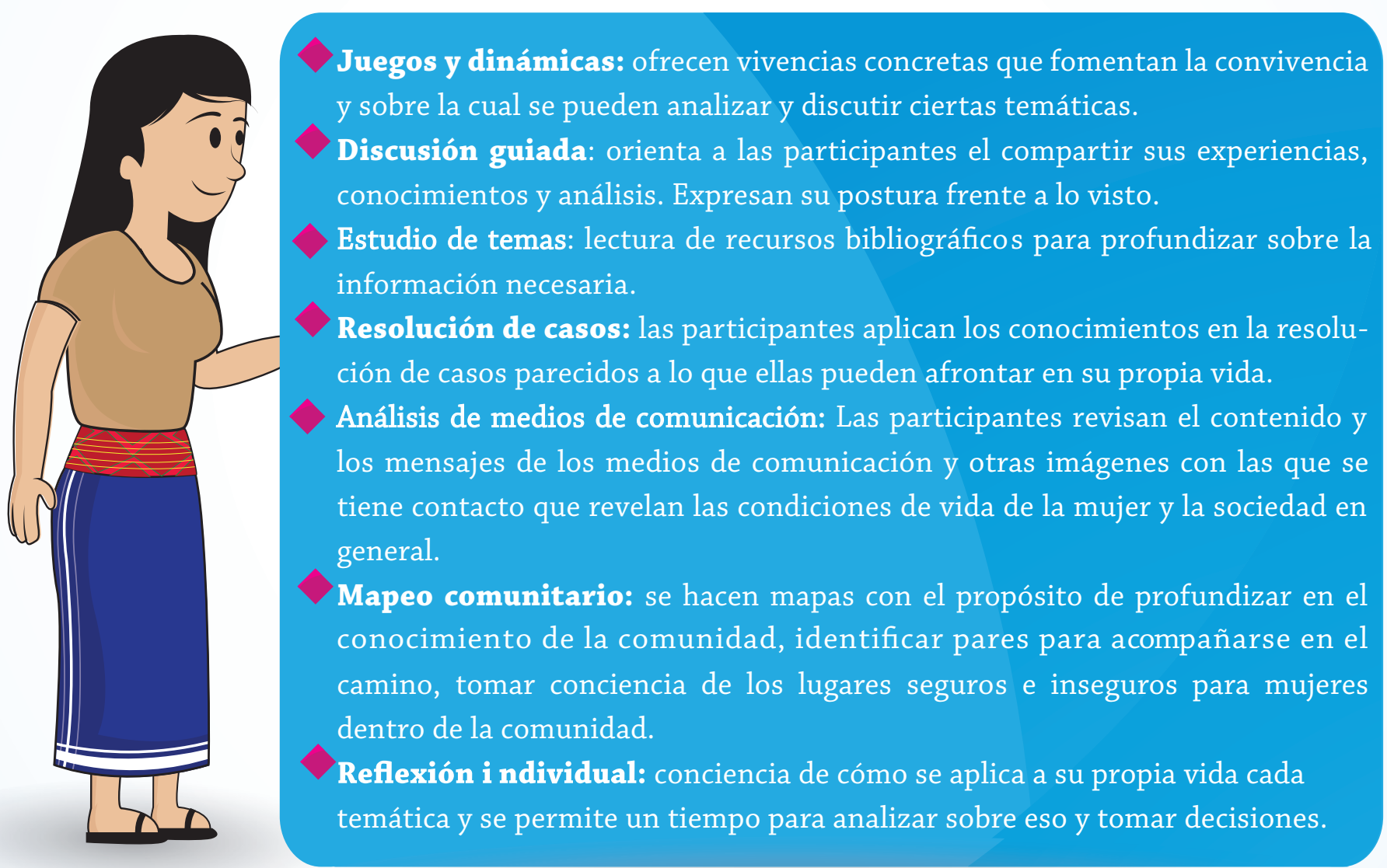

\section{Cada sesión de tema se desarrolla en cuatro fases:}

1.Bienvenida: momento en el cual se da la bienvenida a las participantes, se toma asistencia, se comparten anuncios y situaciones importantes que están sucediendo en la comunidad.

También puede adelantarle un poco al grupo de lo que estarán trabajando ese día. 
2. Introducción de $l$ tema: se introduce mediante una dinámica, historia, juegos y/o imágenes, que permita al grupo ver cómo el tema afecta la vida de las personas en general y casos en los que se evidencia que es importante conocer el tema.

3. Teorizar y definir: por medio de diferentes recursos como hojas de contenidos, lecturas, dinámicas y/o, preguntas el grupo revisa la teoría del tema que se está trabajando y se aprenden los conceptos clave.

4. Aplicación a la vida: usan los conceptos clave para analizar situaciones de su vida. Por medio de diversas dinámicas toman decisiones o desarrollan habilidades que les ayudan a resolver los problemas con los que se enfrentan o prevenir nuevos.

\section{Usando la guía curricular}

Para facilitar a la mentora de grupo el desarrollo de las sesiones, se ofrecen varias herramientas que fortalecen su comprensión del para qué, por qué, cómo y con qué se realiza cada una.

A continuación se describen dichas herramientas:

\section{La tabla para la mentora de grupo}

Permite a la mentora de grupo prepararse adecuadamente para cada sesión, indicando: el nombre y número de la sesión, los objetivos, los conceptos clave, el tiempo requerido, materiales necesarios y recursos de apoyo. No es n ecesario compartir con las participantes esta información.

A continuación un ejemplo:

\subsection{Tengo derechos que me protegen}

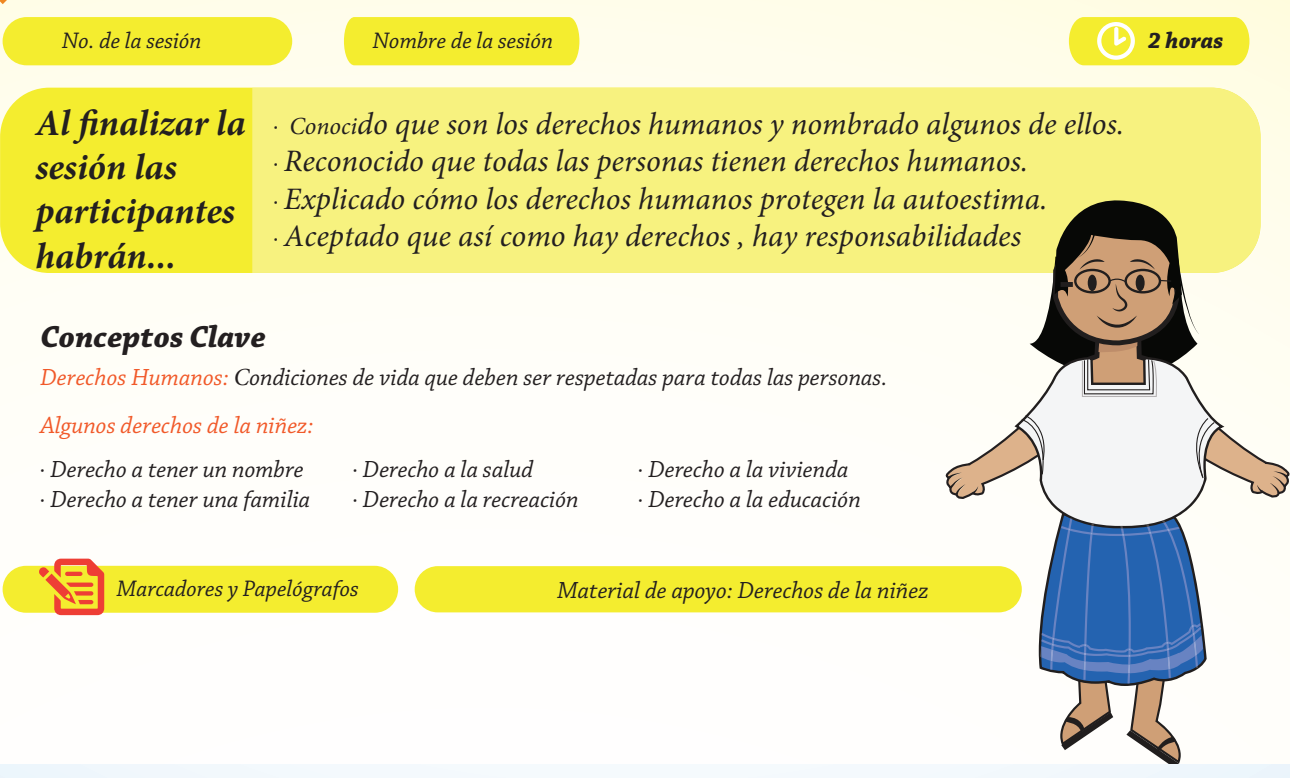




\section{Señales de formato de texto}

\section{Palabras en itálicos}

Frases, palabras o preguntas escritas en itálicas son ideas centralesque deben trabajarse con el grupo. La mentora puede hacer modificaciones para adaptarla intentando mantener la esencia y sentido original del mensaje.

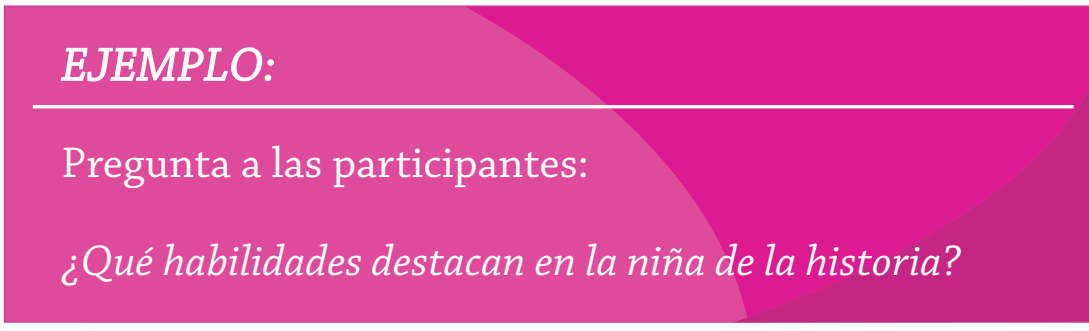

\section{Palabras en negrita}

Las palabras en negrita describen las respuestas esperadas a las preguntas abiertas o claves que se están realizando. Es importante comprender el propósito de las preguntas que se están haciendo para poder orientar y dirigir al grupo hacia dicha reflexión.

\section{EJEMPLO:}

\section{Una habilidad es que puede pensar y decidir qué es lo que ella quiere hacer.}

\section{Caja de técnica de facilitación:}

Técnica de facilitación

Espacio con consejos prácticos para

mejorar la facilitación y las actividades.

\section{Alerta}

Avisa cuando es necesario preparar algo previo a la siguiente sesión.

\section{Materiales}

Espacio con los recursos didácticos, pedagógicos necesarios para realizar la sesión.
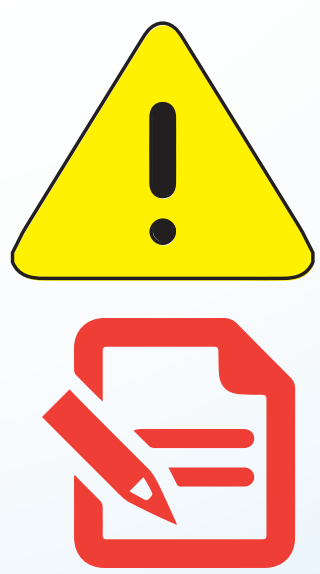

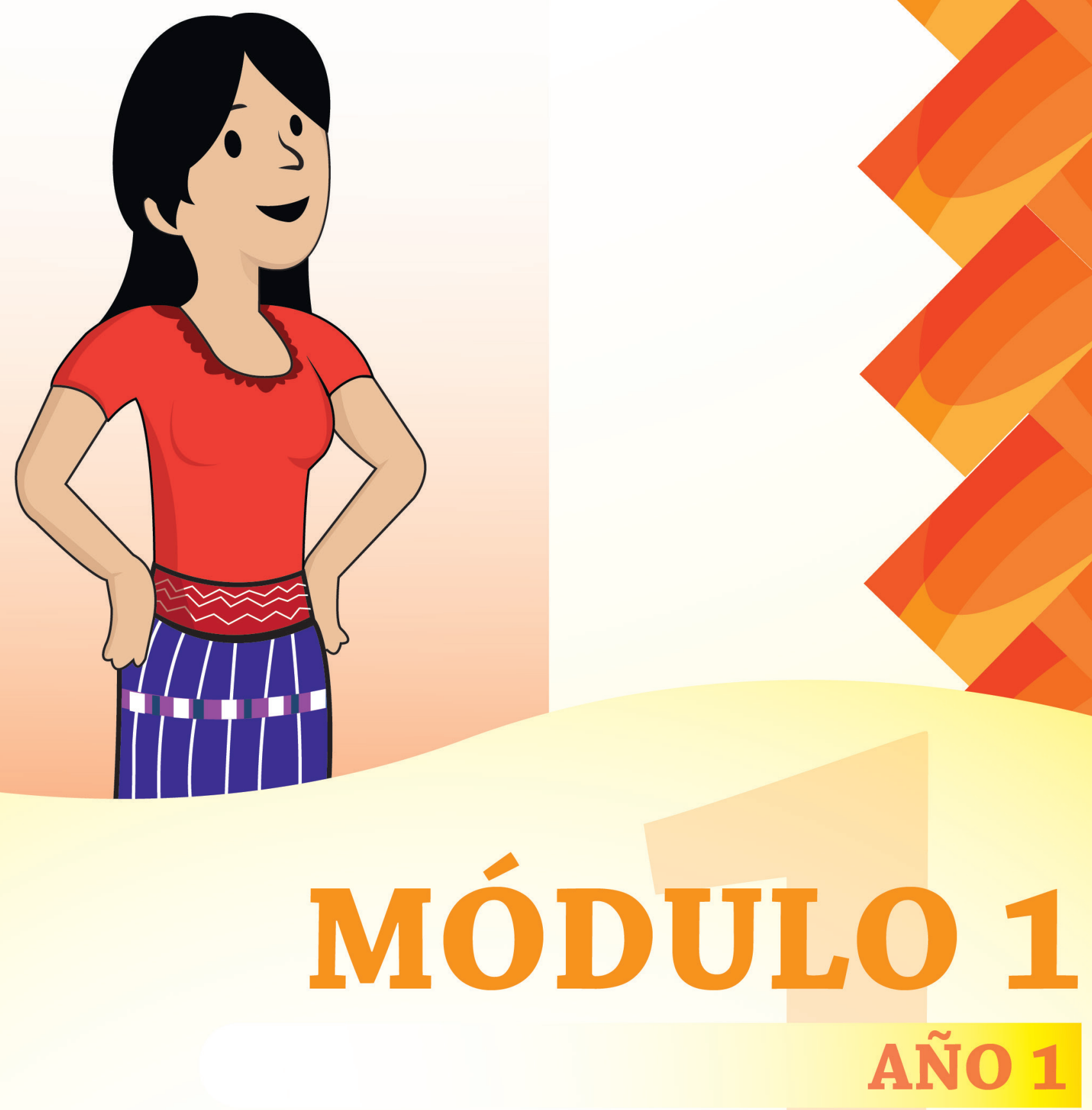

Guía Curricular Integrada 2015 - Population Council 


\section{Créditos}

- Autoras:

$\checkmark$ María Cecilia Garcés de Marcilla/Especialista en Educación

Paola Broll / Oficial del Programa

- Revisión: Alejandra Munguía/ Coordinador de Campo

- Diagramación:Isaí de la Cruz

- Equipo Population Council 2015:

$\checkmark$ Directora de Programas: Alejandra Colom

- Supervisor de Monitoreo y Evaluación y oficial de Programa: Ángel del Valle

Administradora: Ana Lucía Rodríguez

- Mentoras: Elizabeth Vásquez, Claudia Macz, Sonia Chó, Patricia Alva, Maribel Gutiérrez, Fabiola Colop y Rosa Güit 


\section{Grupo de 8 a 12 años}

\section{2 horas}

Al finalizar

la sesión las

participantes

habrán...
- Conocido a sus compañeras de grupo

- Visitado el lugar del espacio seguro

- Decidido cómo serán las relaciones entre ellas en el espacio seguro

- Reconocido que todas las niñas de la comunidad son bienvenidas a Abriendo Oportunidades

- Establecido un plan para llegar seguramente al espacio seguro

- Identificado espacios seguros en su comunidad

\section{Conceptos Clave}

\section{Espacio Seguro:}

Es el lugar y tiempo en el que las niñas adolescentes se reúnen de forma protegida para aprender, compartir y formar una red de amigas en las que se apoyan.

\section{Convivencia:}

Relación respetuosa de la dignidad de las personas, en la que puede iniciar una nueva amistad.

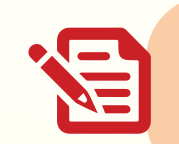

Mapa de la comunidad con el título: "Abriendo oportunidades: Nuestro Espacio Seguro". Marcadores, Papelógrafos, Crayones, Carpetas, Hoja de trabajo "Cambios en mi vida después de Abriendo Oportunidades"

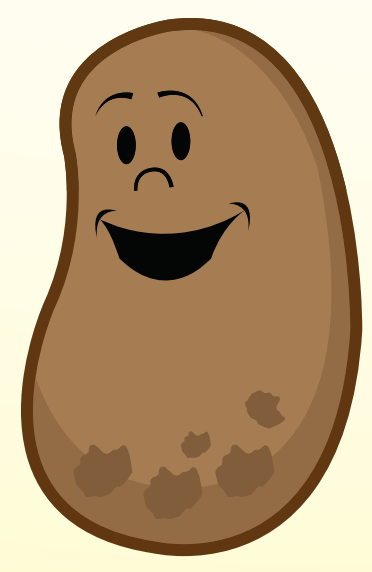

\section{Técnica de facilitación}

Si tiene dificultad para que pasen a presentarse voluntariamente juegue la papa caliente para ver quién será la siguiente en pasar.

Se juega sentando al grupo en círculo y pasando un objeto entre ellas mientras usted aplaude, en el momento en que detiene los aplausos la que está sosteniendo el objeto es la que debe pasar. 


\section{Bienvenida:}

Salude a las participantes y preséntese. Comparta su nombre, de dónde viene y su responsabilidad en el programa Abriendo Oportunidades. Dígales que le emociona mucho trabajar en este programa. Dibuje en el mapa de la comunidad el camino que usted usó para llegar al Espacio Seguro.

Invite a cada participante a presentarse de la misma forma y a dibujar en el mapa el camino usado para llegar hasta el espacio seguro.

\section{Introducción del tema:}

Organice a las niñas adolescentes en grupos según el camino que siguieron. Haga las siguientes preguntas para que las comenten en su grupo.

¿Qué cosas les gustan del camino

¿Qué peligros hay en el camino?

¿Qué lugares en su camino son espacios seguros??

Pida que una integrante de cada grupo que señale en el mapa en dónde se van a reunir. Invite a las niñas a reunirse todas en círculo y dialogue con ellas sobre:

\section{En plenaria les hace las siguientes preguntas:}

¿Cuándo y cómo han visto que una mujer ayuda a otra mujer?

¿Por qué es importante conocer a las otras mujeres

que participan en Abriendo Oportunidades?

\section{Teorizar y definir}

Pida que se pongan de pie en el círculo. Explique que van a realizar una dinámica para conocer a nuevas amigas. Deben seguir sus instrucciones al pie de la letra e intentar conocer a la mayor cantidad de niñas posibles. Diga:

\section{Salude con la mano a cinco niñas que no conocen y pregunten cómo se llaman. \\ 2. Dé la mano a cinco niñas y pregunte cómo se llaman. \\ 3. Choque las puntas de los pies con cinco niñas y pregunte cómo se llaman. \\ 4. Abrace a cinco niñas y pregunte cómo se llaman.}

Pregunte a las participantes:

¿Cómo se sienten al conocer a nuevas amigas?

¿Cómo se sienten al hablar con ellas y de abrazarlas?

¿Les gustaría seguir conociéndoles más? 
Diga a las participantes:

Todas traemos algo especial a nuestro grupo y todas somos bienvenidas. Es importante que nuestro grupo sea un espacio donde podamos soña, cometer errores, aprender y lograr nuestras metas.

A la vista de todas coloque un papelógrafo con el título: "Las niñas aprendemos y nos queremos en el espacio seguro". Pida a las participantes que piensen en cómo quieren que sea el trato entre ellas en el espacio seguro y escriba las respuestas en el papelógrafo.

Al terminar diga a las participantes:

Ahora tenemos nuestro espacio seguro y nuestras normas de convivencia. El espacio seguro es un lugar donde nos reunimos con niñas que llegan a ser nuestras amigas. Aqui podemos sentirnos libres y sin miedo a hablar, tenemos confianza para contar y compartir sobre nuestra vida, podemos aprender de nuestros errores $y$ preguntar cuando no conocemos algo. En este espacio seguro vamos a tener nuevas oportunidades, experiencias que tal vez nos den miedo o nos sorprendan. Las reuniones semanales serán para que trabajemos temas, juguemos y aprendamos manualidades.

\section{¡Levante la mano la niña que es parte del espacio seguro y vendrá todas las semanas!}

\section{Todas deben levantar la mano e insista hasta que todas le confirmen que son parte de Abriendo Oportunidades y están comprometidas a seguir llegando a las sesiones.}

\section{Aplicación a la vida}

Entregue a cada una su pasaporte, permita que le pongan su nombre y dibujen su rostro en el espacio para la foto. Diga a las participantes:

Para cada una de ustedes hay un pasaporte que es solamente suyo y simboliza que pertenecen a Abriendo Oportunidades. En él van a anotar su asistencia a las sesiones y van a elaborar un forro para protegerlo. No lo pierdan, cuídenlo.

Cuando hayan terminado de trabajar su pasaporte, entregue la hoja de trabajo: "Logros en mi vida". Pida que dibujen qué logros esperan alcanzar al participar en Abriendo Oportunidades. Permita que algunas compartan su dibujo. 


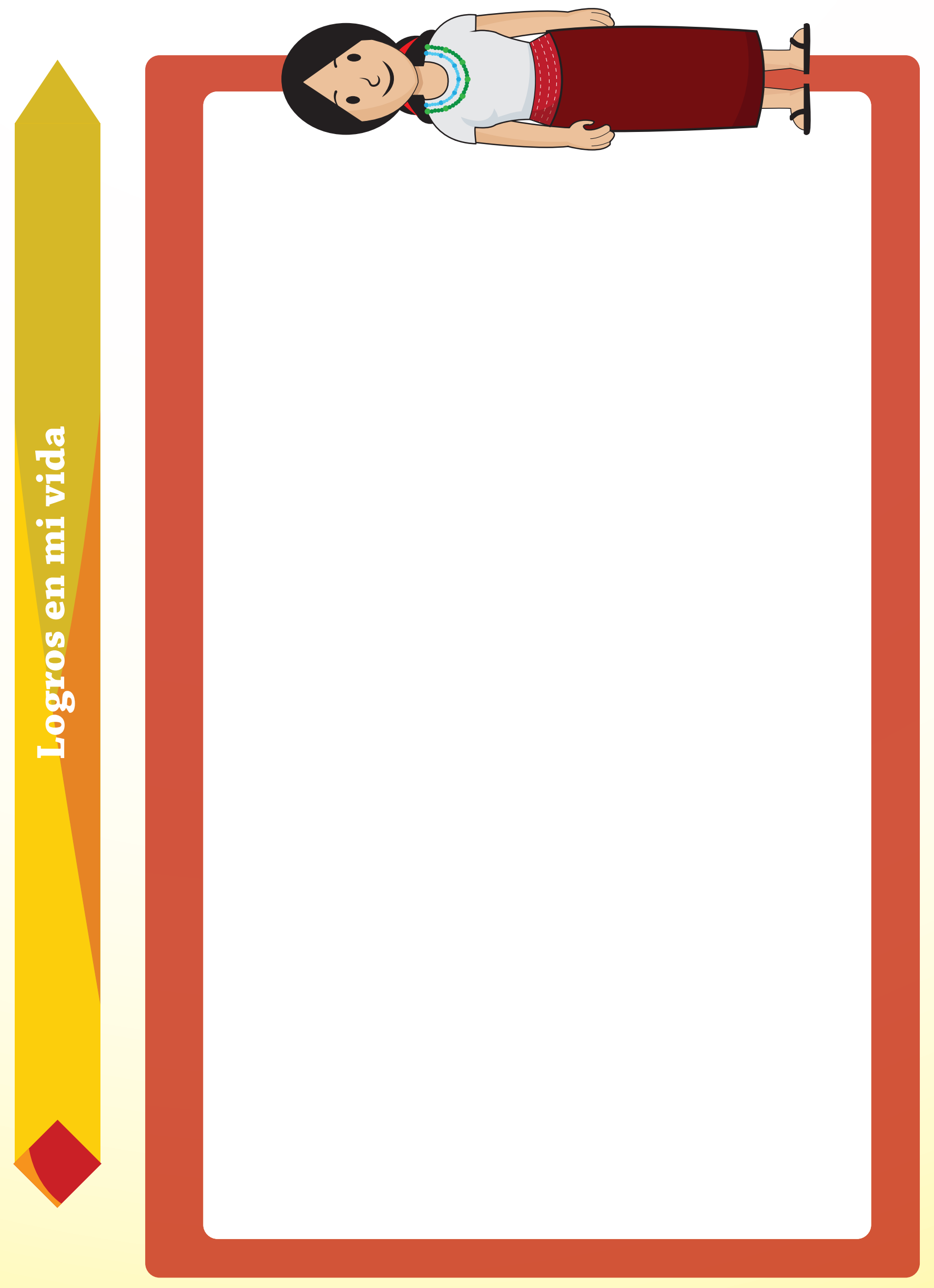


Al finalizar

la sesión las

participantes

habrán...
- Reflexionado sobre sus necesidades nutricionales.

- Reconocido y defendido su derecho a la alimentación en igualdad a los demás integrantes de su familia

- Identificado estrategias para mejorar su nutrición en diferentes momentos de su vida.

\section{Conceptos Clave}

El cuerpo de una mujer cambia mucho según sus actividades, su edad y su cuidado. Cuando es niña, de la alimentación depende su crecimiento y desarrollo. Cuando inicia con la menstruación empieza a tener necesidades especiales por la pérdida de sangre y el desarrollo físico. Al estar embarazada necesita muchas vitaminas, minerales, hierro y ácido fólico. Luego durante el período de lactancia cuando su cuerpo alimenta a sus hijos e hijas también tiene que recibir todos los nutrientes y hierro. Durante la vejez necesita nutrientes especiales para fortalecer sus huesos y cuerpo.

\section{Una botella vacía con el dibujo de una alimento local (maíz, plátano, papa, güicoy...) \\ Dibujos de ocho integrantes de una familia · Un corazón de papel para cada niña \\ Dibujos o imágenes de niñas y muejres con desnutrición \\ Papelógrafos, marcadores}

\section{Bienvenida:}

Dé la bienvenida a las participantes, confirmando quiénes están presentes o ausentes. Comparta que van a jugar y necesitan haber comido bien. Pida que le compartan qué cosas comieron o cuántas veces han comido en el día.

\section{Introducción del tema:}

Comente a las participantes que van a imaginar que son una familia de ocho integrantes, que solamente tiene una mazorca para comer. Pida que formen ocho grupos y entregue por grupo el dibujo de uno de los integrantes de la familia. En su grupo deben escribir porqué él o ella merece comerse la mazorca. Pida que completen la siguiente oración con su argumento para defender el derecho que tiene a la mazorca. Entregue a cada grupo medio papelógrafo con la siguiente oración incompleta:

Yo soy: y tengo derecho de comer porque: 
Luego pida que formen un círculo y en el centro coloque la botella vacía con el dibujo del maíz encima. Gire la botella y cuando se detenga, pida al grupo al que está apuntando que comparta su papelógrafo. Al terminar de pasar todos los grupos, pregunte.

• ¿Quiénes necesitan la alimentación?

- Quién les convenció mejor de tener derecho a los alimentos?

¿Cómo se reparten los alimentos en las casas de esta comunidad?

¿Qué alimentos quedan para las niñas?

Técnica de facilitación

Si la botella apunta dos veces al mismo grupo, pida que pase el siguiente, de manera que no se repitan y pasen todos los grupos.

Puede forrar la botella con tuza también para dar la apariencia de una mazorca. La botella girará mejor en una superficie lisa.

Coloquen los dibujos de los integrantes de la familia en el orden en que se reparte la comida en las familias de esta comunidad, poniendo de primero al que empieza a comer y de último al último en recibir la comida.

\section{¿Cómo afecta esta situación a las niñas?}

Son las últimas en comer, reciben menos comida y la comida menos nutritiva.

¿Cómo afecta la salud y autoestima de las niñas?

Provoca cansancio, desnutrición, falta de vitaminas, problemas para trabajar y estudiar. Se sienten menos importantes y menos apreciadas por no recibir el alimento igual que el resto de personas de la familia. Además el efecto de no comer les hace más difícil estudiar y mantener las notas en la escuela, esto las hace ver y sentir como menos capaces que los niños. Se enferman más.

\section{Teorizar y definir}

Presente a las participantes imágenes de niñas y mujeres que sufren desnutrición y permita que las observen y luego hagan una lluvia de ideas de las señales de desnutrición que ven. Apunte las respuestas en un papelógrafo.

Puede preguntarles:

¿Qué cambios o síntomas se dan en el cuerpo de una persona que tiene muy mala nutrición?

Debilidad, cansancio y desgano.

Palidez en la piel, las encías.

Poco cabello que pierde su color.

Llagas en la piel y en la boca.

Lengua dolorosa.

Delgadez excesiva.

Estómago abultado.

Enfermedades frecuentes y diarreas.

Hinchazón de los pies, cara y manos. 
¿Qué actividades realizan las niñas que las hacen necesitar alimentos?

¿Cómo es el desempeño escolar de una niña que no recibe suficientes alimentos?

¿Qué alimentos deben comer más?

¿Cómo podemos explicar en nuestra casa que necesitamos que nos den alimentos en las mismas condiciones que a los demás?

\section{Aplicación a la vida:}

Entregue a cada niña un corazón y pida que escriban en él las cosas que hacen para que su corazón se sienta feliz, le escriban su nombre y se lo cuelguen en el cuello. Luego pida que cada una presente su corazón y diga:

"Yo tengo necesidad y derecho de comer bien porque cuando mi cuerpo está alimentado y sano puedo:

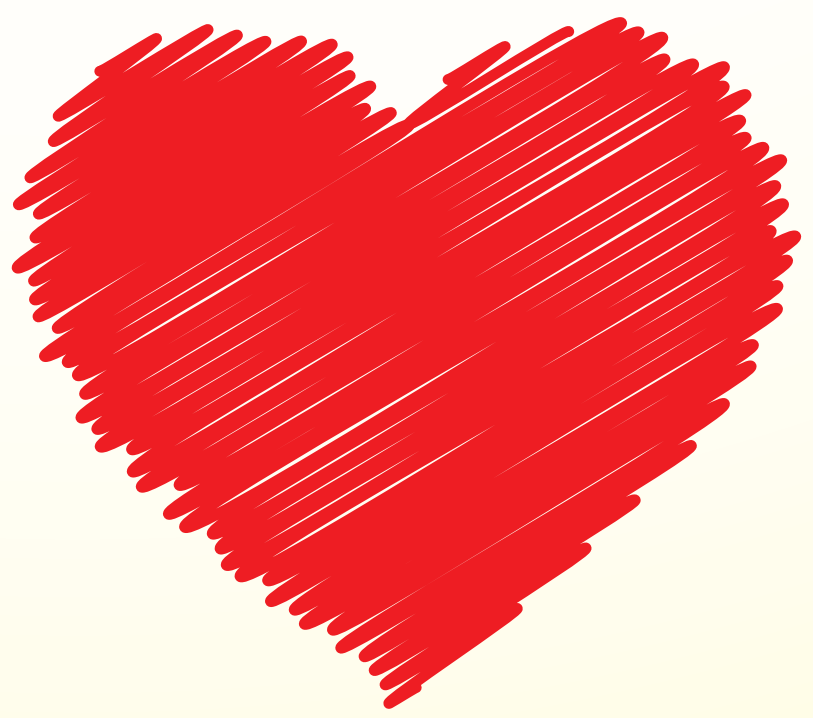




\subsection{Me conozco y me quiero}
Al finalizar
- Identificado sus rasgos personales que les diferencian de las demás personas.
la sesión las
- Mencionado sus fortalezas y fortalezas de sus compañeras que son importantes para
participantes sobreponerse a los retos que viven.
habrán...
- Reconocido que pertenecer a ciertos grupos les fortalece.

\section{Conceptos Clave \\ Identidad:}

Conciencia que tiene una persona de sus rasgos y características que la definen y diferencian de los demás. La identidad puede ser personal y también grupal.

\section{Pertenencia:}

Sentimiento que se tiene de formar parte de un grupo por compartir características con sus integrantes y diferenciarse de otros grupos.

Fortaleza: rasgos, cualidades, características propias e innatas de una persona que le permiten superar los retos que enfren-tan y alcanzar sus metas en la vida. Nadie puede quitarle a una persona sus fortalezas.

Debilidades: rasgos, cualidades y características propias que no han sido desarrolladas al máximo de sus posibilidades.

\section{Bienvenida:}

Dé la bienvenida del día a las participantes, confirmando quiénes están presentes o ausentes. Aproveche para decirles algo que a usted le gusta sobre cada una, una cualidad que tienen, una habilidad especial. Mencione especialmente a las niñas que participan poco o que son más reservadas.

\section{Introducción del tema:}

Cuente al grupo la siguiente historia:

\section{Técnica de facilitación}

Puede llevar dibujos de los personajes para mostrarlos mientras va contando la historia.

Al contar la historia use voces, entonaciones,

gestos, sonidos...todo lo que pueda para hacerla más amena y entendible a las participantes.

Si tiene tiempo puede pedir desde antes a algunas voluntarias que dramaticen la historia para sus compañeras.

Irma, Elbia, y Olga son buenas amigas y van juntas a la escuela. Esta mañana Olga y Elbia se extrañaron al ver que Irma no había llegado a clases. Ella siempre llega temprano y con ganas de estudiar y haciendo el ambiente de la clase divertido. Sabían que sin Irma, no se reirían igual y el día sería aburrido. La primera clase del día era Ciencias Sociales y Olga pensó que para ayudar a Irma, le tomaría notas de la clase. Cuando terminó de copiar, Olga tuvo un problema: tenía dos hojas iguales y se empezaba a confundir entre lo suyo y lo de Irma. En ese momento fue cuando Elbia, que era muy ordenada, también ayudó. Ella le pidió a Olga las copias y las fue guardando a lo largo de todo el día, para entregarlas en orden y completas a Irma. 
Mientras tanto, Irma estaba en su casa sintiéndose muuuuy mal. Su mamá, muy buena cocinera, le estaba preparando un caldito y tortillas de prisa pues a medio día llegaban las tías de Irma a la casa, para que ella se pueda ir a trabajar al comedor donde cocinaba. No sabian qué tenía. Irma se quejaba de mucha fiebre, dolor de estómago y mareos. Sabían que sí seguía así, tendrían que llevarla a la Clínica, realmente está lejos y necesitarían transporte.

La tía de Irma que conocía a todas las personas de la Aldea porque era muy amable, se acercó a la casa de Don Juan, para contarle la situación de su sobrina. Don Juan sin dudarlo le ofreció llevarla en su picop al Centro de Salud, si fuera necesario, él era muy buen piloto y más para casos de emergencia. Intercambiaron números de teléfono y la tía de Irma le agradeció su amabilidad. Lo bueno es que al pasar el día, Irma se sintió mejor y su cuerpo se levantaba. Recibió con muchos ánimos a Irma y Olga que la visitaron por la tarde para dejarle las copias que le tomaron en la Escuela. Las tres amigas se sintieron felices de estar juntas y poderse ayudar unas a otras.

Reflexione con las participantes sobre la historia y la forma de relacionarse entre las personas. Pregunte a las participantes:

¿Qué le paso a Irma?

Se enfermó y no fue a la escuela un día.

¿Qué extrañarían más las amigas de Irma durante su ausencia?

El ambiente divertido y cómo les hace reir.

¿Qué fortaleza tenía Irma que le ayudaba a ganar los grados siempre?

Su puntualidad y deseo por estudiar.

¿Qué personas se preocuparon por ella durante el día?

Olga, Don Juan, Elbia, Mamá.

Dibuje a las personas alrededor de Irma, puede hacerlo usted o pedir a

algunas niñas que los pasen a dibujar rápidamente.

¿¿Qué relación tenía Irma con cada persona?

Olga y Elbia: amigas de la escuela.

Mamá y sus tías: parientes.

Don Juan: vecino de la aldea.

Escriba el parentesco a la par de cada personaje.

¿Qué fortaleza puso cada persona al servicio de Irma?

Olga: Buena para copiar

Elbia: Ordenada

Mamá: Buena para cocinar

Tía: amable

Don Juan: Bueno para manejar en casos de emergencia

¿A qué grupos de personas pertenece Irma?

Escuela (Olga y Elbia).

Familia (Tías y mamá).

Don Juan (Vecino de la aldea).

Puede hacer un círculo alrededor de Irma y los personajes para mostrar cada grupo y cómo Irma pertenece a varios grupos que la apoyaron. 


\section{Teorizar y definir:}

Coloque un papelógrafo en blanco al frente y diga a las participantes que así como Irma se enfermó, todas afrontamos retos en nuestra vida que nos dificultan el desarrollo. Entregue un crayón a cada una para que pase al papel a escribir un reto que enfrenta. Luego de un tiempo retome lo que escribieron leyendo algunas de sus respuestas.

En el mismo papelógrafo y sobre lo que escribieron, escriba la palabra FORTALEZA. Pida que le digan qué es una fortaleza y complemente sus respuestas con el concepto clave haciendo énfasis en que todas las personas tenemos fortalezas que nos ayudan a enfrentar y sobreponernos a nuestros retos.

Entregue a cada niña una la hoja de trabajo "Mis fortalezas" pida que se dibuje. Alrededor de su dibujo debe escribir 5 rasgos, cualidades o características propias que la hacen fuerte.

Pida que den vuelta a la hoja y la dividan en cuatro partes. Mientras lo hacen diga a las participantes:

En la historia, cada amiga es diferente porque tiene fortalezas y debilidades. La fortaleza es algo que podemos hacer bien. Además formamos partes de grupos y comunidades, somos parte de una familia, de Abriendo Oportunidades, de Amigas, de una Iglesia, de una Escuela. Se puede decir que pertenecemos a ellos cuando nos sentimos parte y las otras personas nos reconocen parte de él también.

Van a identificar los grupos a los que ustedes pertenecen. En cada espacio escriban un grupo al que pertenecen (pueden ser: familia, escuela, amigas, vecindario, iglesia, abriendo oportunidades, etc.) y el nombre de una persona del grupo que te cuida y protege.

\section{Aplicación a la vida:}

Pida que se unan en parejas, cada niña va a hacerle una medalla a su compañera en la que debe escribir una fortaleza de su amiga. Dé tiempo para que la escriban y la decoren .Colocadas en círculo cada niña entregará y colocará la medalla a su compañera, presentando a todo el grupo lo que escribió de ella. Usted debe escribir en un papelógrafo oda slas fortalezas que digan para ver la riqueza que tiene el grupo de Abriendo Oportunidades de la comunidad.

Entregue a las participantes la hoja de trabajo Mis fortalezas y Mis debilidades para que en cada una escriban cómo aprovechan una de sus fortalezas y cómo pueden sobreponerse a una de sus debilidades. 


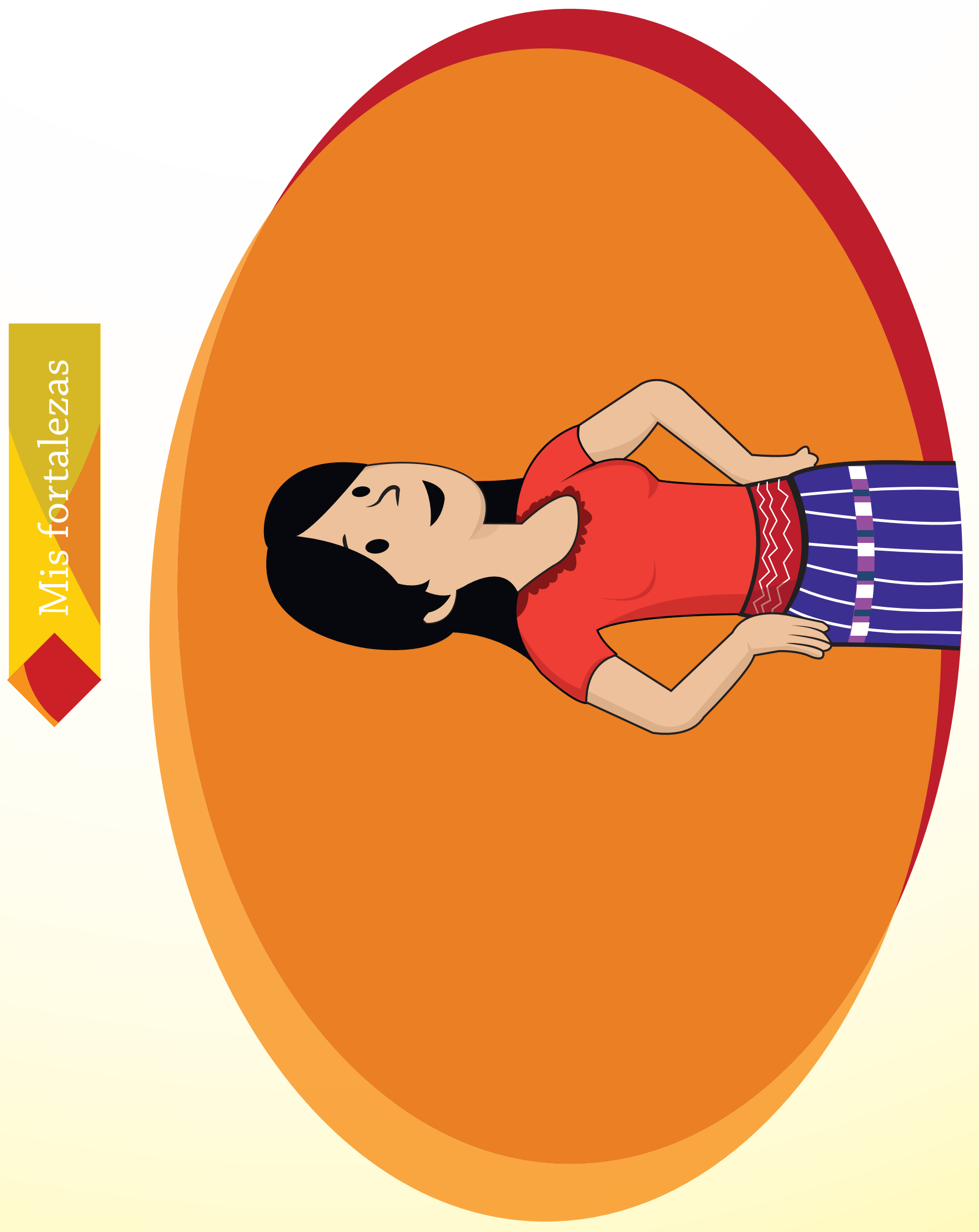




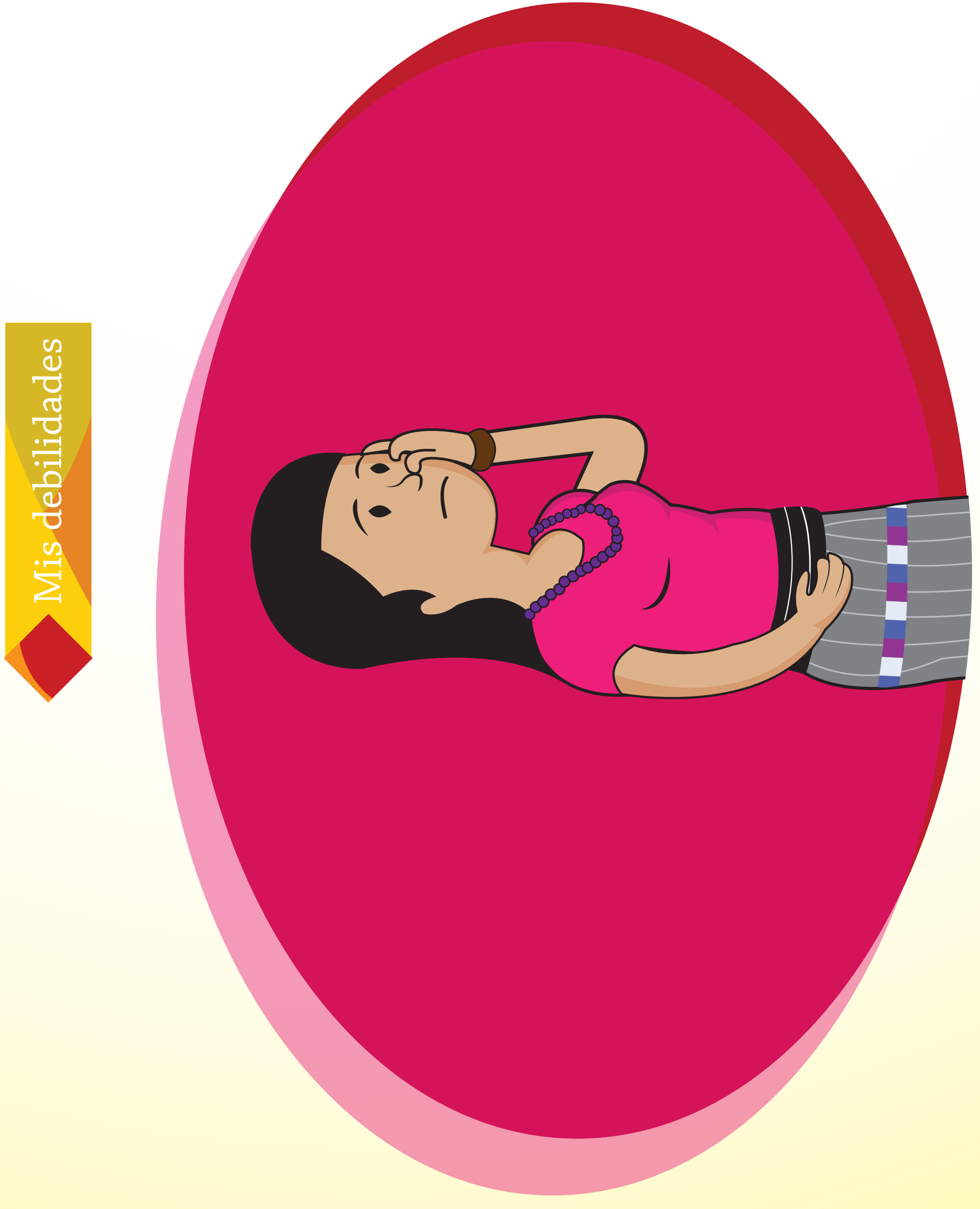




\subsection{Soy valiosa por ser quien soy}

\section{Al finalizar \\ la sesión las \\ participantes \\ habrán... cuidarla. \\ Explorado sus sentimientos hacia sí mismas identificando que son valiosas. \\ Comprendido qué es el autoestima y cómo ayuda a las personas a desarrollarse. \\ Identificado situaciones que afectan de forma negativa/positiva su autoestima y formas para}

\section{Conceptos Clave}

\section{Autoestima:}

es la imagen y percepción que tiene una persona de sí misma, sobre la cual se valora. Se desarrolla en interacción con la familia, las amigas, la escuela, la iglesia, los medios de comunicación y todos los mensajes que le hablan sobre sí misma. La forma de verse y valorarse puede cambiar de un momento a otro durante la vida, afecta nuestro comportamiento con nosotras mimas y con las demás personas.

\section{2 horas}

\section{Bienvenida:}

\section{Papelógrafos · Marcadores}

Definición de qué es autoestima

Hoja de trabajo

Lectura: Una nueva Rosa

(página 10 y 11 del libro Mi voz, mi sueño, mi mundo)

Dé la bienvenida a las participantes. Verifique quién está presente y ausente. Pregunte por las ausentes para ver si las compañeras saben dónde están y qué pueden hacer para ayudarlas para que no dejen de llegar a las sesiones. Aproveche para platicar cómo han sentido las sesiones de encuentro y qué ha cambiado en ellas desde que están en Abriendo Oportunidades.

\section{Introducción del tema:}

Diga a las participantes, vamos a leer una historia del libro mi voz, mi sueño, mi mundo, forme 3 grupos haciendo una dinámica y dé a cada grupo un segmento de la historia, al finalizar dé una hoja a cada grupo y pida que contesten las siguientes preguntas:

\section{¿De quién es la historia? \\ ¿Qué dice la historia?}

¿Qué les llamó la atención de la historia?

Dé 5 minutos para que respondan y al terminar diga que cada grupo va a compartir sus respuestas, anote las respuestas en un papelógrafo. 
Pida a las participantes que se vuelvan a reunir en sus grupos, para responder a las siguienes preguntas

\section{1. ¿Cómo la historia de Rosa se parece a la nuestra? \\ 2. ¿Qué características tiene Rosa? \\ 3. ¿Qué características tengo que me hacen compararme con Rosa y cuáles me hacen diferente? \\ 4. ¿Desde cuándo pienso que tengo estas características?}

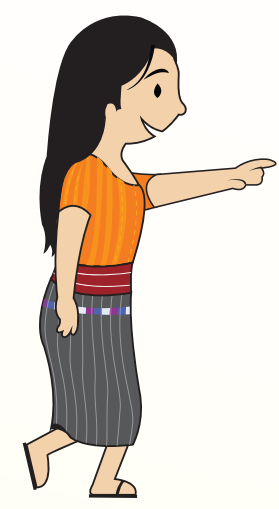

Juegue con ellas la dinámica de las estatuas, pida a unas 5 personas voluntarias, cada voluntaria para escoger un papel, en ellos dirá si es la escultora o es una estatua. Diga que la escultora va a representar con cada estatua una característica que haya destacado de ella y de Rosa, al terminar de colocarlas el resto de las participantes deben adivinar ¿Cuál es la característica que representa cada estatua?, juegue un par de rondas de las estatuas cambiando en cada ronda a la escultora y luego pida que regresen en plenaria y pregunte a las participantes:

¿Qué características destacaron de sí mismas?

¿Qué experiencias de la vida son las que las han hecho verse a sí mismas como Rosa?

\section{Teorizar y definir}

Presente en un papelógrafo la palabra AUTOEstima. Platique con ellas qué significan las dos palbras que componen (Autoestima) y qué significará el concepto. Apunta palabras clave que definan el concepto en el pizarrón. Diga a las participantes:

Ustedes han pensado en características que las hacen compararse con Rosa y otras que las hacen diferentes, esto muestra cómo se ven a sí mismas y cómo se sienten consigo mismas. Eso es autoestima.

Lea junto con ellas el concepto de autoestima, cómo se forma, qué cosas la componen. Reflexione con las participantes acerca de cuándo han tenido experiencias que forman para bien o para mal su autoestima.

Diga a las participantes:

Todas las personas tenemos autoestima y la forma en que nos portamos unas y unos con otras también afecta la autoestima de las demás. A veces sin darnos cuenta afectamos la autoestima de las amigas. 
¿Cuándo he visto que alguien afecta de forma negativa la autoestima de una mi amiga? Cuando hay chismes, cuando le hablan mal, cuando no la aceptan en un grupo, cuando no la dejan estudiar.

\section{¿Qué pasa cuando ella se siente mal consigo misma?}

No puede hacer las cosas que quiere, le da miedo y no se atreve a probar sus habilidades. No se relaciona con las personas, puede ser más enojada y frustrada.

¿Cómo ayudas a mejorar la autoestima de otras mujeres de la comunidad?

Aceptarla en el grupo, tener buena comunicación, respetarlas, valorar a las mujeres que participan, no hacer chismes de otras mujeres, trabajar en equipo con ellas, compartir las dificultades y buscar soluciones juntas, decirle sus fortalezas y sus cualidades.

\section{Aplicación a la vida:}

Pedir que en la hoja de trabajo “¿Cómo me valoro a mi misma?” escriba en cada pétalo de la flor una cosa que les gusta muchísimo de sí misma y en el centro escriben cómo se sienten cuando piensa en estas cosas.
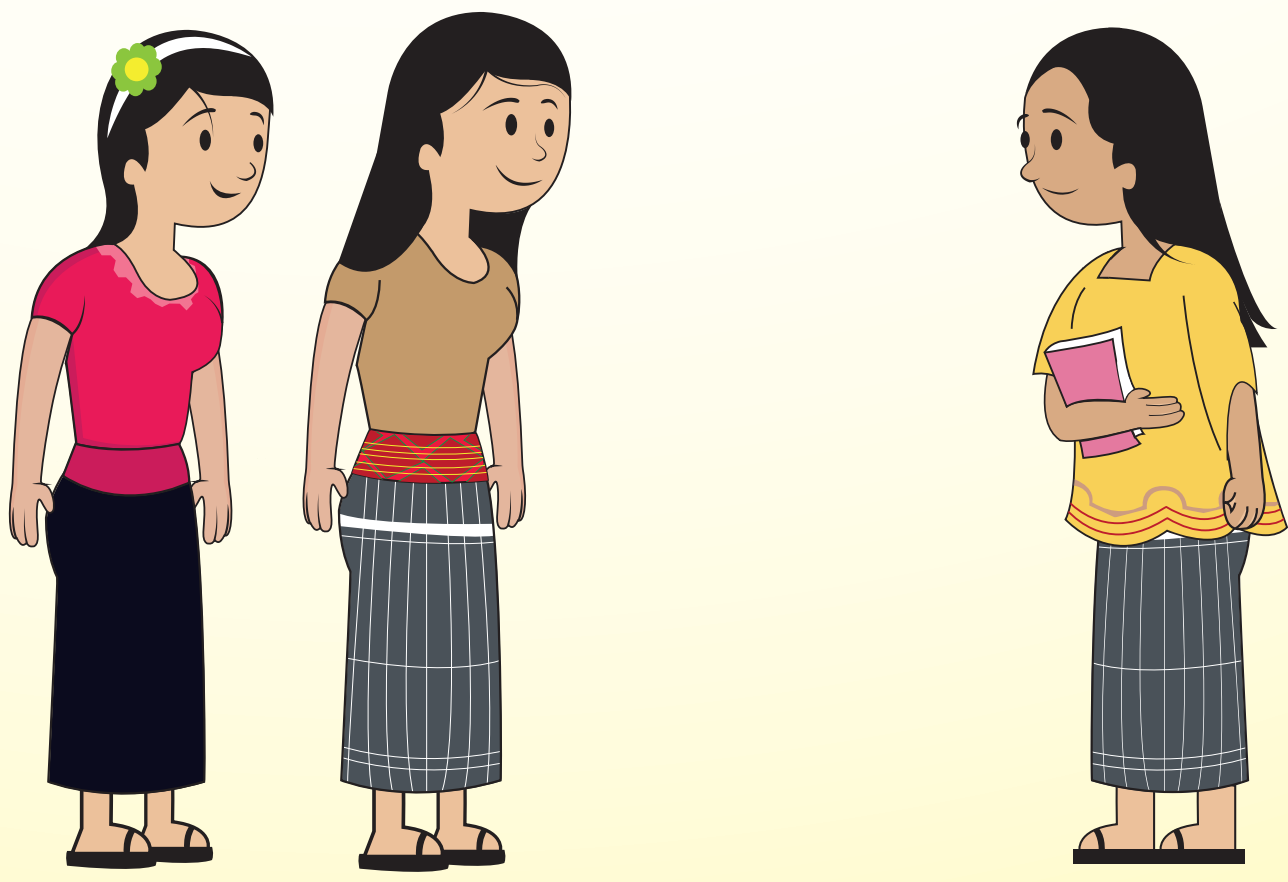


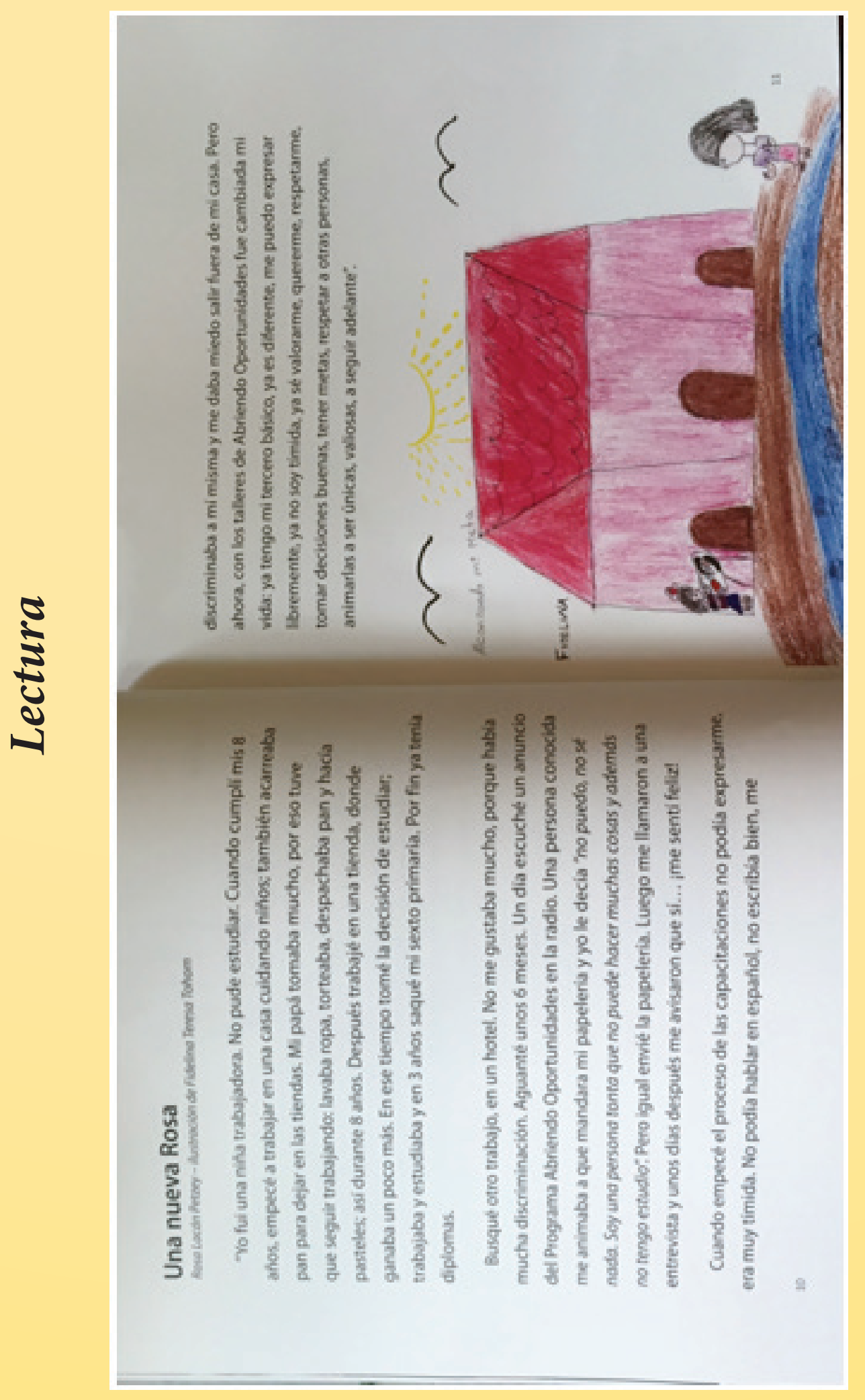




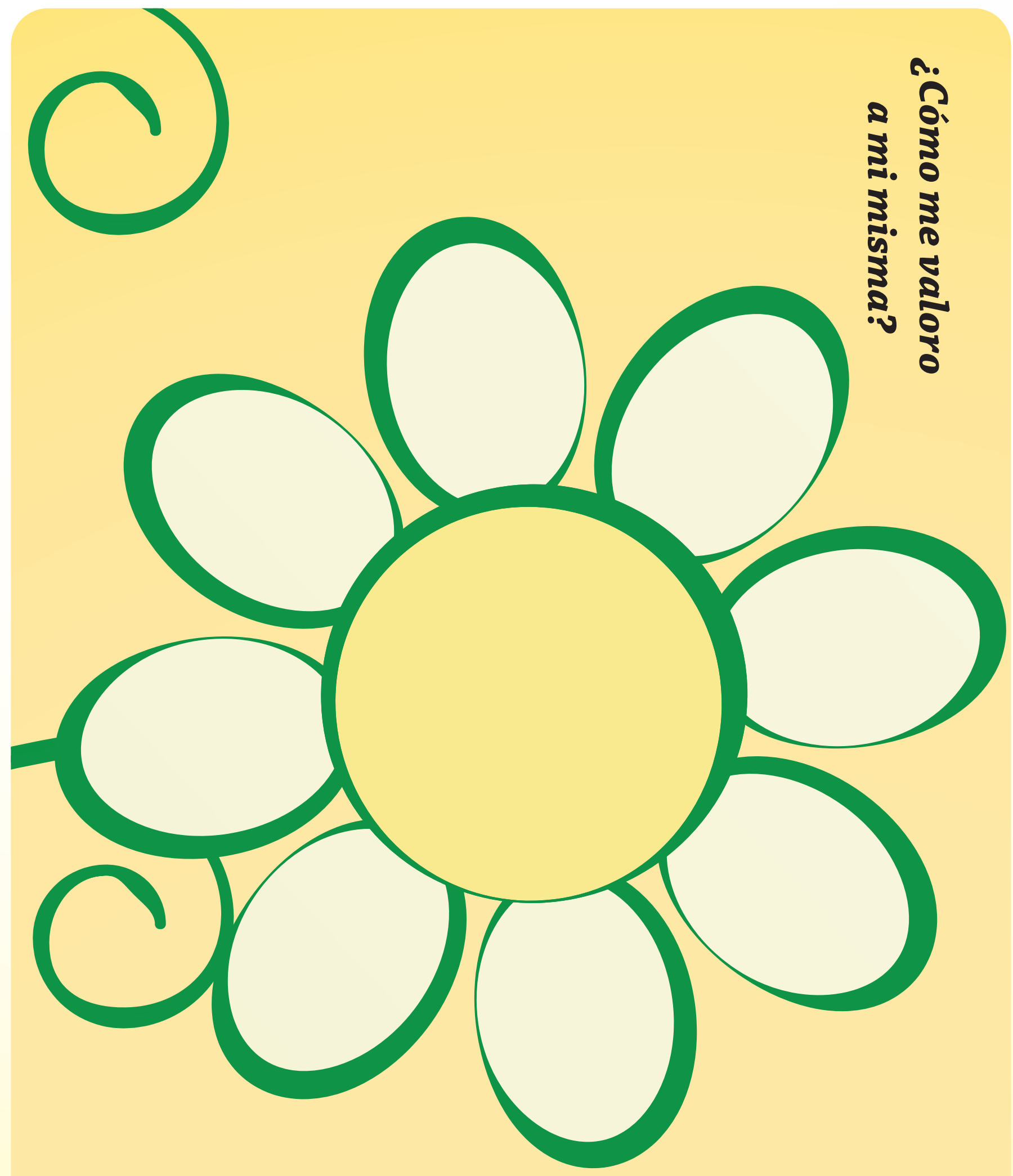




\subsection{Tengo derechos que me protegen}

\section{Al finalizar \\ la sesión las \\ participantes \\ habrán...}

- Conocido qué son los derechos humanos y nombrado algunos de ellos.

- Reconocido que todas las personas tienen derechos desde que nacen.

Explicado cómo los derechos humanos protegen el autoestima.

Aceptado que así como hay derechos y también hay responsabilidades.

\section{Conceptos Clave}

Derechos Humanos: condiciones de vida mínimas que todas las personas deben disfrutar para sí misma en su desarrollo como seres humanos, desde el momento en que nacen.

Responsabilidad: valor de cumplir voluntariamente con las obligaciones propias y especialmente el cumplimiento del respeto a las demás personas.

Algunos derechos de la niñez:

- Derecho a tener un nombre

- Derecho a tener una familia

- Derecho a la salud

- Derecho a la recreación

- Derecho a la vivienda

- Derecho a la educación

Marcadores. Papelógrafos · Imágenes de niñas y niños en diferentes condiciones del país y diferentes lugares.

Recursos de apoyo: Derechos de la niñez

\section{Bienvenida}

Dé la bienvenida a las participantes, confirmando quiénes están presentes o ausentes. Comparta con ellas que el día de hoy van a conocer sobre lo que todo el mundo está de acuerdo que deberían ser las condiciones de vida para todas las personas del planeta y especialmente para que niños y niñas sean felices y puedan crecer bien.

\section{Introducción al tema:}

Muestre a las niñas varias imágenes de niños y niñas viviendo en diferentes lugares y condiciones (incluya a quienes viven en pobreza y quienes no). Permita que observen las fotos y hagan una lluvia de ideas de las cosas que se necesitan para alcanzar el desarrollo de nuestras fortalezas. Apunte sus respuestas en un papelógrafo. Pida que clasifiquen las imágenes en dos grupos:

1. Los que tienen lo que necesitan.

2. Los que carecen de lo que necesitan para desarrollarse plenamente como humanos.

Sobre cada grupo pregunte:

¿Qué características predominan en el grupo?

¿Cómo creen que es la autoestima de estos niños o niñas? 


$$
\begin{gathered}
\text { ¿En qué se parecen ustedes y ellos? } \\
\text { ¿En qué nos parecemos todos los niños y niñas? }
\end{gathered}
$$

Luego enséñeles una imagen de niños y niñas que viven en condiciones buenas de vida y que satisfacen sus necesidades y haga las mismas preguntas al grupo.

¿Qué cosas le hacen falta a estos niños y niñas?

¿Cómo les afectará para crecer bien esa falta de cosas?

¿Cómo creen que es la autoestima de estos niños y niñas?

¿En qué se parecen ustedes a ellos y ellas?

¿En qué se diferencian de los niños y niñas de la primera foto?

¿En qué nos parecemos todos los niños?

\section{Explique diciendo a las participantes:}

En el mundo los niños y niñas igual que los jóvenes, adultos y ancianos compartimos la dignidad humana, eso significa que todas somos importantes y valiosas y vale la pena que estemos vivas. Pero al mismo tiempo las personas viven de formas muy diferentes, algunas tienen mucho para conseguir todo lo que necesitan y otras personas no tienen lo que necesitan. Viendo las fotos y pensando en sus vidas, se van a juntar en grupos de cuatro niñas y van a hacer una lista de las cosas más importantes que todos los niños y niñas deberían tener para vivir felices y crecer bien.

Divida en grupos a las participantes para que trabajen con niñas de diferentes edades y se puedan ayudar unas a otras. Luego permita que todos los grupos presenten su lista de cosas.

\section{Teorizar y definir:}

Comente al grupo: Hace más de 50 años se reunieron los líderes del mundo para hacer una lista como la que ustedes acaban de hacer y a esas cosas que todos debemos tener para ser felices y crecer bien ellos, les llamaron los Derechos Humanos.

Entregue a cada niña la hoja de trabajo "Derechos de la niñez" . Lea junto con el grupo los derechos y vaya resolviendo dudas en el camino y subrayando con ellas las palabras clave de cada derecho.

Para cada derecho leído, solicite que las participantes le den un ejemplo de cómo sí o cómo no se respeta en sus propias vidas y porqué es importante para su autoestima.

Mientras avanza en la lectura revise con ellas y marque en los papelógrafos los derechos que se incluyen en las listas hechas por las participantes anteriormente. Luego pregunte:

¿Qué significa que estos derechos sean para todos los niños y niñas?

$$
\text { ¿A quiénes protege? }
$$

¿Qué derechos sí se cumplen en la comunidad?

¿Cuáles se cumplen menos para las niñas de la comunidad?

¿Por qué si se cumplen nuestros derechos ayuda a nuestra estima? 
Reflexione con ellas que cada derecho trae una responsabilidad. Ellas son responsables de respetar sus derechos y los de sus compañeras. Pregunte:

¿Cómo pueden apoyar a que todas tengan derechos?

¿Qué responsabilidades tienen?

\section{Aplicación a la vida:}

Formadas en grupos, entregue a cada uno un papelógrafo con el título de uno de los siguien tes derechos.

GRUPO 1: Todas las niñas y niños tiene el derecho a tener un nombre y apellido.

GRUPO 2: Todas las niñas y niños tienen el derecho a tener una familia que le cuida y quiera.

GRUPO 3: Todas las niñas y niños tienen el derecho a tener una vivienda digna en donde vivir.

GRUPO 4: Todas las niñas y niños tienen el derecho a ir a la escuela para aprender cosas interesantes e importantes para su vida.

GRUPO 5: Todas las niñas y niños tienen el derecho a recibir atención médica para cuidar su salud.

\section{En la parte baja de cada papelógrafo escriba:}

GRUPO 1: Cuando las niñas tenemos nombre nos sentimos...

GRUPO 2: Cuando las niñas tenemos familia nos sentimos...

GRUPO 3: Cuando las niñas tenemos vivienda digna estamos...

GRUPO 4:

Cuando las niñas vamos a las escuela aprender podemos...

GRUPO 5: Cuando las niñas estamos saludables nos gusta...

Pida que el grupo haga un dibujo para dar a conocer cómo el derecho se cumple en la vida de las niñas y niños de la comunidad. Luego deben completar la oración que se encuentra en la parte baja de su papelógrafo. 
Al finalizar

la sesión las

participantes

habrán...
- Conocido a sus compañeras de grupo

- Visitado el lugar del espacio seguro

- Decidido cómo serán las relaciones entre ellas en el espacio seguro

- Reconocido que todas las adolescentes de la comunidad son bienvenidas a Abriendo Oportunidades

- Establecido un plan para llegar seguramente al espacio seguro

- Identificado espacios seguros en su comunidad

- Hablado sobre los riesgos que corren las mujeres adolescentes en la comunidad.

\section{Conceptos Clave}

\section{Espacio Seguro:}

Es el lugar y tiempo en el que las niñas adolescentes se reúnen de forma protegida para aprender, compartir y formar una red de amigas en las que se apoyan.

\section{Convivencia:}

Relación respetuosa de la dignidad de las personas, en la que puede iniciar una nueva amistad.

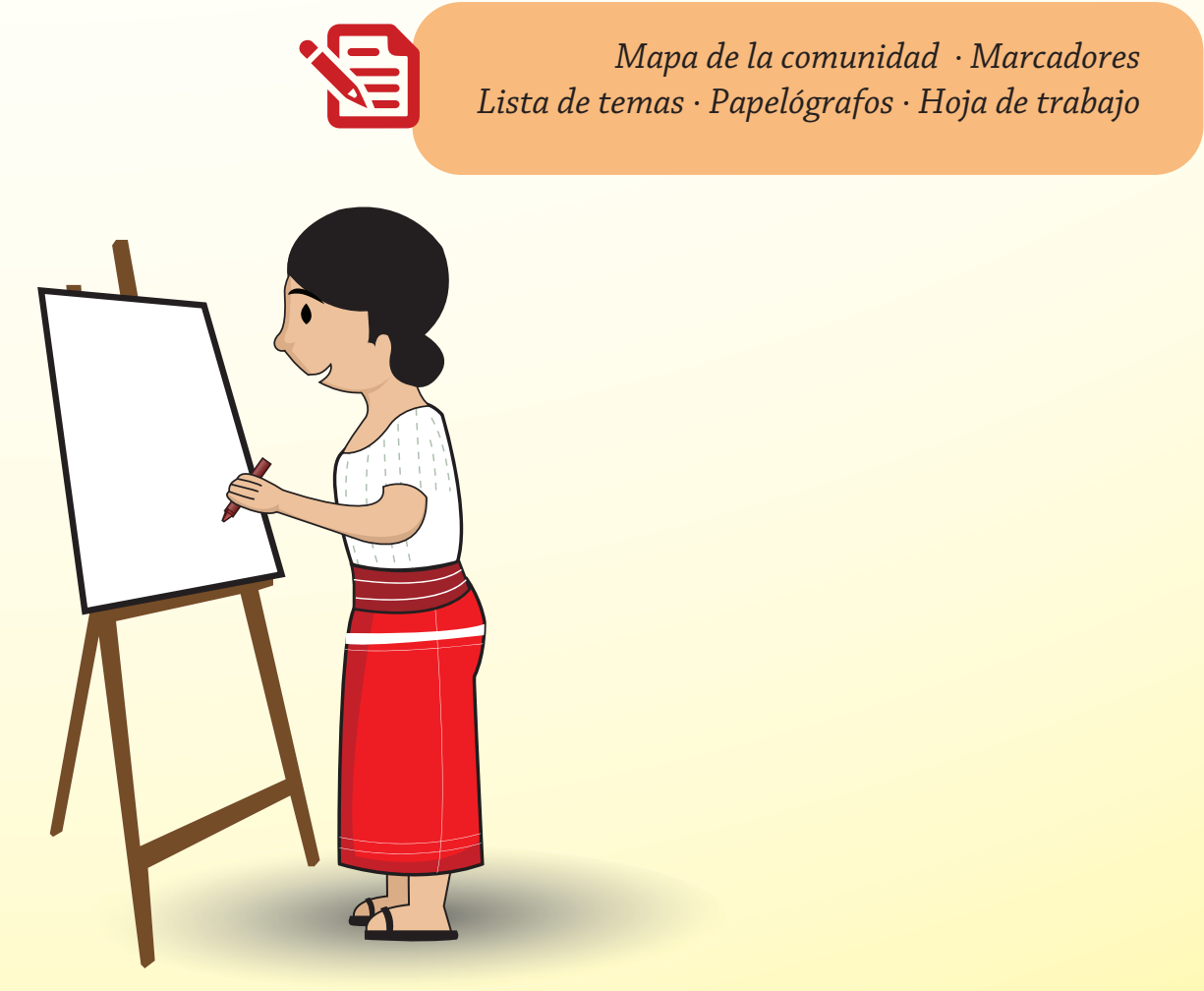




\section{Bienvenida}

Salude a las participantes y preséntese. Comparta su nombre, de dónde viene y su responsabilidad en el programa Abriendo Oportunidades.

En el mapa de la comunidad, dibuje el camino que usted usó para llegar al Espacio Seguro.

Invite a cada participante a presentarse de la misma forma y a dibujar en el mapa el camino usado para llegar hasta el espacio seguro.

\section{Técnica de facilitación}

Si tiene dificultad para que pasen a presentarse voluntariamente juegue la papa caliente para ver quién será la siguiente en pasar.

Se juega, sentando al grupo en círculo y pasando un objeto entre ellas mientras usted aplaude, en el momento en que detiene los aplausos la que está sosteniendo el objeto es la que debe pasar.

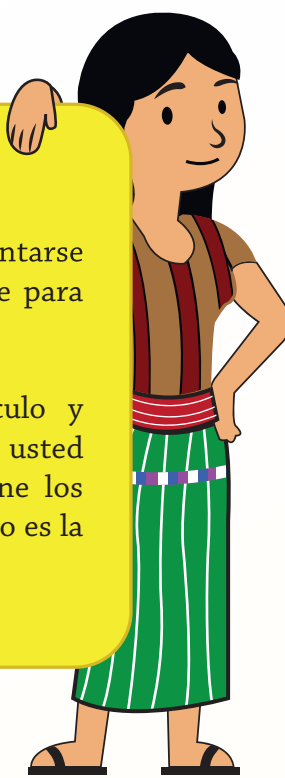

\section{Introducción del tema:}

Pida a las participantes que se reúnan en grupos según el camino que siguen y en sus grupos discutan las preguntas que encuentran en el papel:

¿Qué cosas les gustan del camino?

¿Qué peligros hay en el camino?

¿Qué riesgos corren al ir en el camino?

¿Qué lugares en su camino son espacios seguros?

¿En qué puntos del camino se van a encontrar para venir juntas al espacio seguro?

¿En qué momentos podemos necesitar ayuda de otras mujeres?

¿Cuándo y cómo han visto que una mujer ayuda a otra en esta comunidad?

¿Por qué es importante conocer a las otras mujeres que participan en Abriendo Oportunidades?

\section{Teorizar y definir}

Pida que se pongan de pie en el círculo. Explique que van a realizar una dinámica para conocer a nuevas amigas. Deben seguir sus instrucciones al pie de la letra e intentar conocer a la mayor cantidad de amiga posible. Diga:

1. Salude con la mano a cinco jóvenes que no conoce y pregunte cómo se llaman.

2. Dé la mano a cinco jóvenes y pregunte cómo se llaman.

3. Choque las puntas de los pies con cinco jóvenes y pregunte cómo se llaman.

4. Abrace a cinco jóvenes y pregunte cómo se llaman. 
Pregunte a las participantes:

¿Cómo se sienten al conocer a nuevas amigas?

¿Cómo se sienten al hablar con ellas y de abrazarlas?

¿Les gustaría seguir conociéndoles más?

Diga a las participantes:

Todas traemos algo especial a nuestro grupo y todas somos bienvenidas. Es importante que nuestro grupo sea un espacio donde podamos soñar, cometer errores, aprender y lograr nuestras metas.

A la vista de todas coloque un papelógrafo con el título: "Las adolescentes aprendemos y nos queremos en el espacio seguro". Pida a las participantes que piensen en cómo quieren que sea el trato entre ellas en el espacio seguro y escriba las respuestas en el papelógrafo.

Al terminar diga a las participantes:

Ahora tenemos nuestro espacio seguro y nuestras normas de convivencia. El espacio seguro es un lugar donde nos reunimos con jóvenes que llegan a ser nuestras amigas. Aqui podemos sentirnos libres y sin miedo a hablar, tenemos confianza para contar y compartir sobre nuestra vida, podemos aprender de nuestros errores $y$ preguntar cuando no conocemos algo. En este espacio seguro vamos a tener nuevas oportunidades, experiencias que tal vez nos den miedo o nos sorprendan. Las reuniones semanales serán para que trabajaremos temas, juguemos y aprendamos manualidades.

\section{¡Levante la mano quien es parte del espacio seguro y vendrá todas las semanas!}

Todas deben levantar la mano e insista hasta que todas le confirmen que son parte de Abriendo Oportunidades y están comprometidas a seguir llegando a las sesiones.

\section{Aplicación a la vida}

Entregue a cada una su pasaporte, permita que le pongan su nombre y dibujen su rostro en el espacio para la foto. Diga a las participantes:

Para cada una de ustedes hay un pasaporte que es solamente suyo y simboliza que pertenecen a Abriendo Oportunidades. En él van a anotar su asistencia a las sesiones y van a elaborar un forro para protegerlo. No lo pierdan, cuídenlo.

Presente la lista de los temas que se estarán viendo en las sesiones e invite a que los lean de forma individual. Entregue la hoja de trabajo: "Logros en mi vida". Pida que dibujen qué logros esperan alcanzar al participar en Abriendo Oportunidades. Permita que algunas compartan su dibujo.

Como actividad para desarrollar en su casa, solicite que realicen la hoja de trabajo: “Qué puede cambiar en mi vida". 


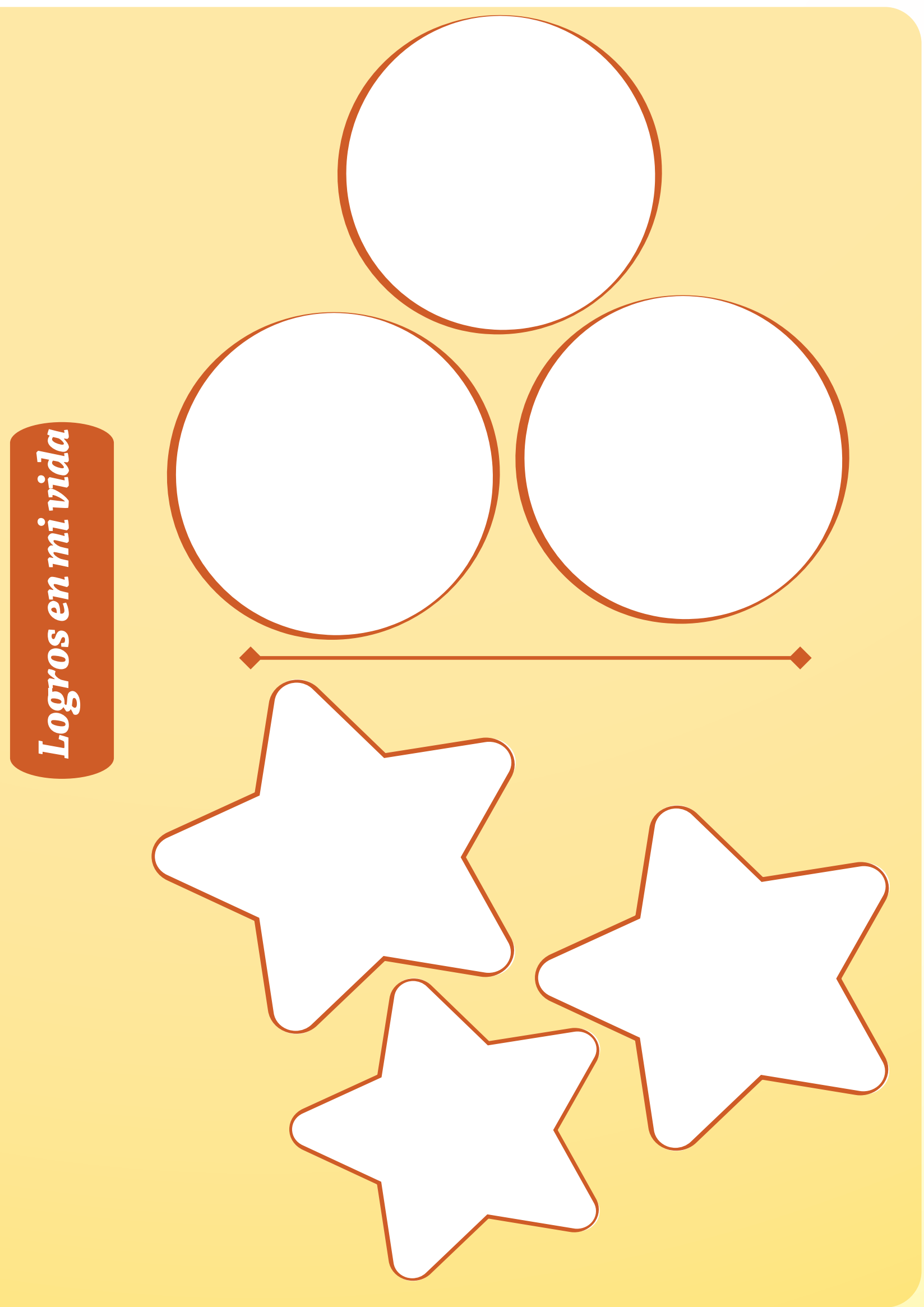




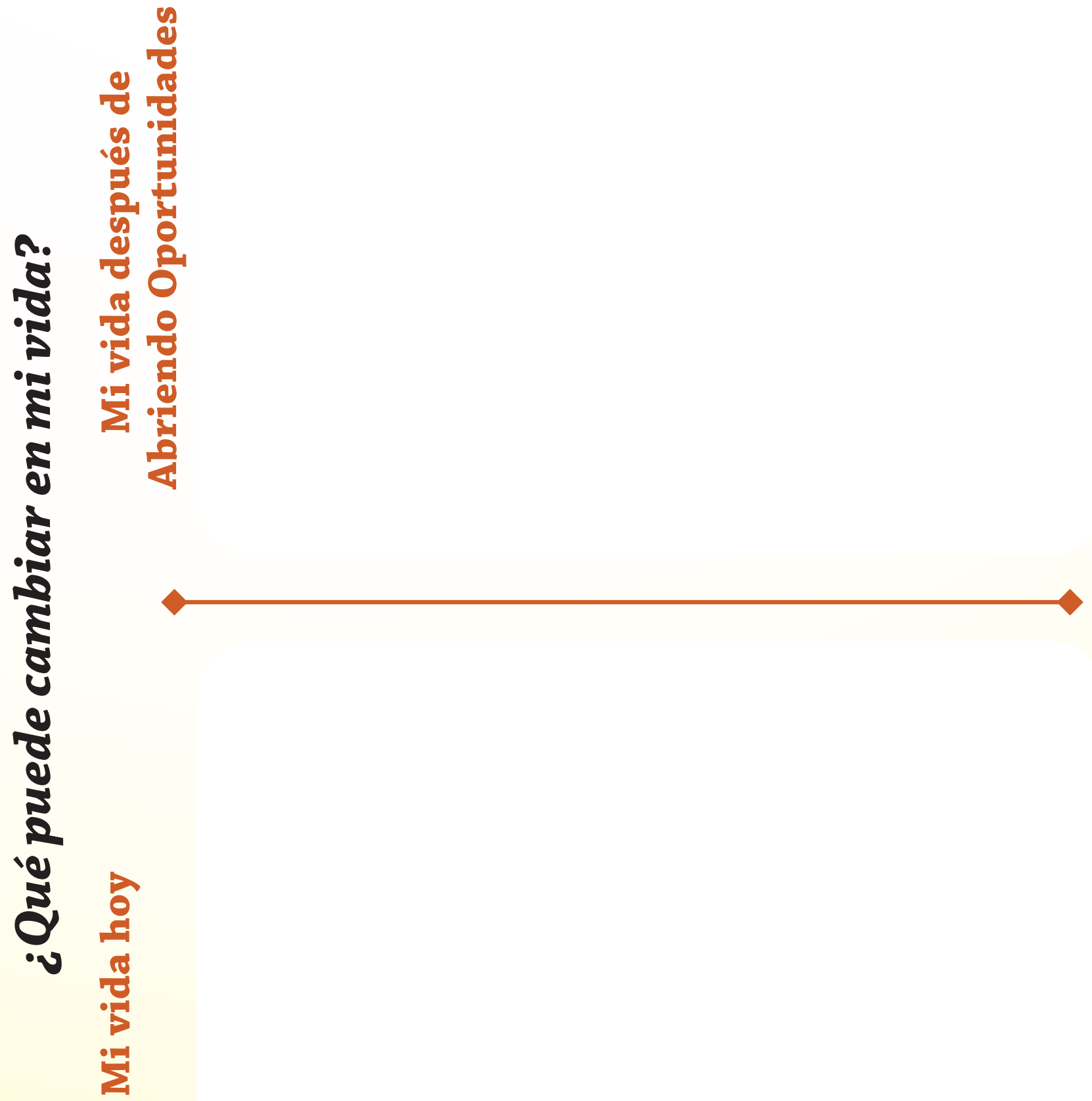




\subsection{Alimentación y las necesidades de una mujer}

$\begin{array}{ll} & \text { - Conocido las necesidades nutricionales de una mujer. } \\ \text { Al finalizar } & \text { - Identificado estrategias para mejorar la nutrición de las mujeres en diferentes momentos } \\ \text { la sesión las } & \text { de su vida. } \\ \text { participantes } & \text { - Reflexionado sobre el efecto de la nutrición de la mujer en su desarrollo integral sobre los demás } \\ \text { habrán... } & \text { integrantes de la familia. } \\ & \text { - Reconocido y defendido su derecho a la alimentación en igualdad a los demás integrantes de su } \\ & \text { familia }\end{array}$

\section{Conceptos Clave}

El cuerpo de una mujer cambia mucho según sus actividades, su edad y su cuidado. Cuando es niña, de la alimentación depende su crecimiento y desarrollo. Cuando inicia con la menstruación empieza a tener necesidades especiales por la pérdida de sangre y el desarrollo físico. Al está embarazada necesita muchas vitaminas, minerales, hierro y ácido fólico. Luego durante el período de lactancia cuando su cuerpo alimenta a sus hijos e hijas también tiene que recibir todos los nutrientes y hierro. Durante la vejez necesita nutrientes especiales para fortalecer sus huesos y cuerpo.

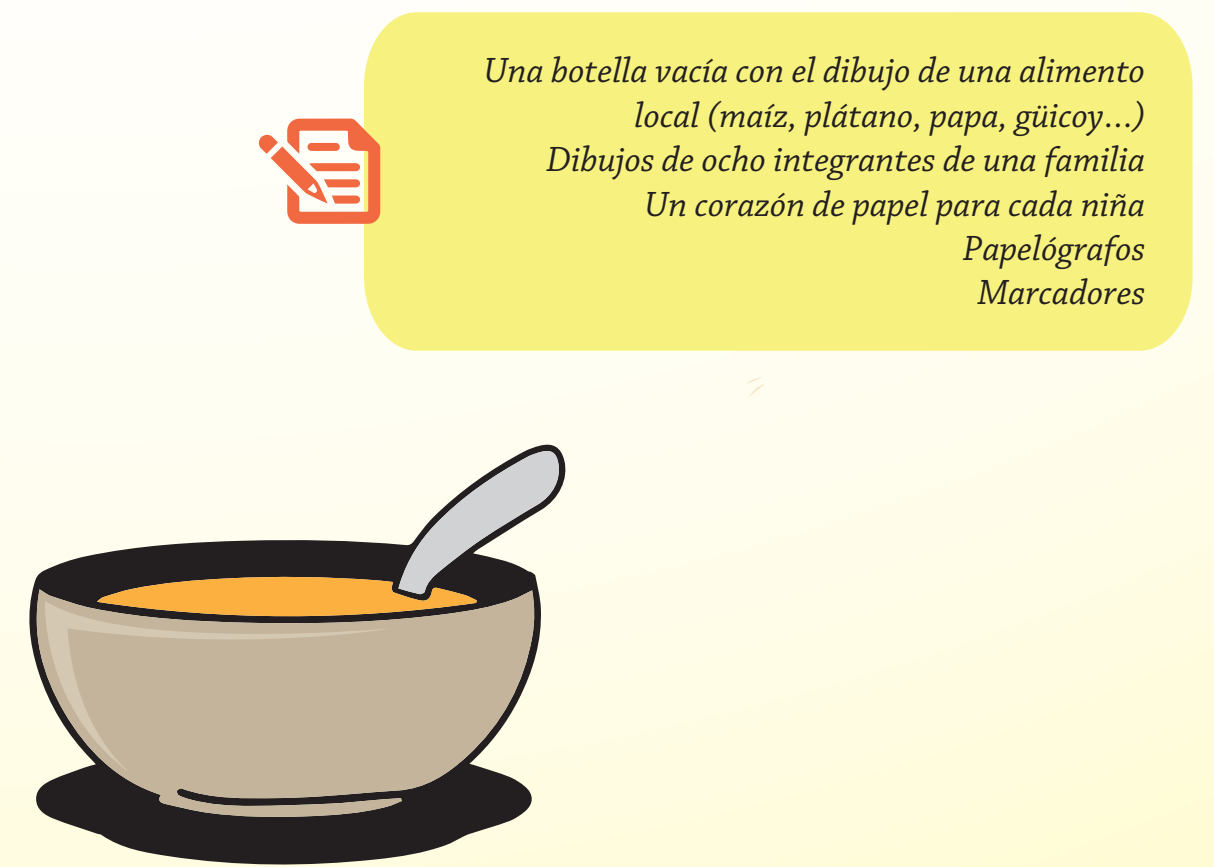




\section{Bienvenida}

Dé la bienvenida a las participantes, confirmando quiénes están presentes o ausentes. Comparta que van a jugar y pregunte a las participantes si comieron el día de hoy y qué comieron. Explique que necesitan tener ganas de jugar y haber comido bien.

\section{Introducción del tema:}

Pida a las participantes formar ocho grupos y entregue a cada grupo el dibujo del integrante de una familia. Comente a las participantes que son una familia de ocho integrantes, que no tiene mucho para comer, cada grupo debe pensar las razones por las que el integrante que tienen es quien debe recibir el alimento disponible. Permítales 10 minutos para discutirlo.

Luego pida que regresen con sus imágenes a formar un círculo y en el centro coloque la botella vacía con el dibujo del maíz encima. Gire la botella y cuando se detenga, pida al grupo al que está apuntando que comparta porqué el integrante que tienen es quien debe comer el maíz. Al terminar de pasar todos los grupos pregunte:

¿Cómo se reparten los alimentos en las casas de esta comunidad?

\section{Técnica de facilitación}

Si la botella apunta dos veces al mismo grupo, pida que pase el siguiente, de manera que no se repitan y pasen todos los grupos.

Puede forrar la botella con tuza también para dar la apariencia de una mazorca.

La botella girará mejor en una superficia lisa.

¿Cómo afecta esta situación a las niñas, adolescentes y mujeres de la comunidad? Son las últimas en comer, reciben menos comida y la comida menos nutritiva.

Cómo afecta la salud y autoestima de las niñas, adolescentes y mujeres de la comunidad?

Provoca cansancio, desnutrición, falta de vitaminas, problemas para trabajar y estudiar. Se sienten menos importantes y menos apreciadas por no recibir el alimento igual que el resto de personas de la familia. Además el efecto de no comer les hace más difícil estudiar y mantener las notas en la escuela, esto las hace ver y sentir como menos capaces que los niños. Se suelen enfermar más.

\section{Teorizar y definir:}

Presente a las participantes fotos de mujeres que sufren de desnutrición y permita que las observen. Pida que hagan una lluvia de ideas de las señales de desnutrición que ven en las mujeres de la imagen, apunte las respuestas en un papelógrafo. Puede preguntarles: 
¿Qué cambios o síntomas se dan en el cuerpo de una persona que tiene muy mala nutrición?

- Debilidad, cansancio y desgano.

- Palidez en la piel, las encías.

- Poco cabello que pierde su color.

- Llagas en la piel y en la boca.

- Lengua dolorosa.

- Delgadez excesiva.

- Estómago abultado.

- Enfermedades frecuentes y diarreas

Hinchazón de los pies, cara y manos

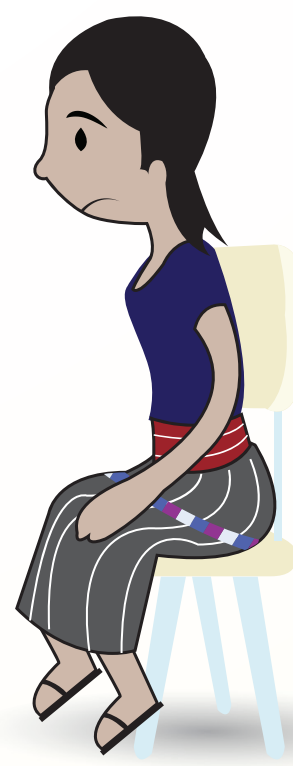

¿En qué momentos de vida de las mujeres se necesitan alimentos especiales para tener buena nutrición? Menstruación, embarazo, lactancia, siempre.

¿Qué alimentos están disponibles en nuestra comunidad que tienen mucho hierro, proteínas y vitaminas para que comamos a lo largo de nuestra vida?

\section{Hierbas, frijoles, verduras, frutas, carne, pollo, huevo, leche, sal}

\section{Aplicación a la vida:}

Forme tres grupos entregando a cada uno un papelógrafo y marcadores. Pida a cada grupo que dibuje un tiempo de comida completo y nutritivo para las niñas, jóvenes y mujeres de su comunidad. El tiempo de comida debe ser: barato, con alimentos que se consiguen en la comunidad, alimentos variados, sabrosos y nutritivos. Deben desarrollar una oración mediante la que convencen que la nutrición de la mujer es importante a cualquier edad.

Permita 10 minutos para que cada grupo trabaje y luego pida que pasen a presentar su oración y el conjunto de menús. Vaya aplaudiendo y felicitando a los grupos. 


\subsection{Meconozco y me valoro}
Al finalizar
- Identificado que son parte de varios grupos con los que conviven y aportan.
la sesión las
participantes
habrán...
- Mencionado sus fortalezas y en sus compañeras
- Reconocido que pertenecer a un grupo las fortalece

\section{Conceptos Clave}

Identidad: Conciencia que tiene una persona de sus rasgos y características que la definen y diferencian de los demás. La identidad puede ser personal y también grupal.

Pertenencia: Sentimiento que se tiene de formar parte de un grupo por compartir características con sus integrantes y diferenciarse de otros grupos.

Fortaleza: rasgos, cualidades, características propias e innatas de una persona que le permiten superar los retos que enfrentan y alcanzar sus metas en la vida. Nadie puede quitarle a una persona sus fortalezas.

Debilidades: rasgos, cualidades y características propias que no han sido desarrolladas al máximo de sus posibilidades.

\section{Marcadores $\cdot$ Papelógrafos} Hoja de trabajo "Mis Fortalezas y Mis Debilidades" Material surtido para hacer flores

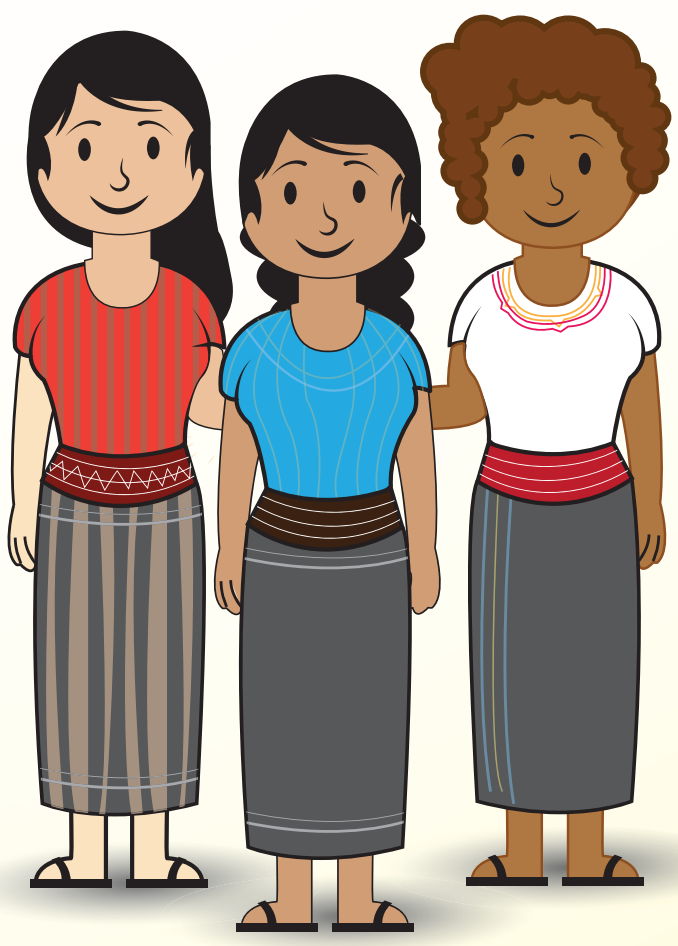

\section{Bienvenida}

Dé la bienvenida a las participantes, confirmando quiénes están presentes o ausentes. Aproveche para decirles algo que a usted le gusta sobre cada una, una cualidad que tienen, una habilidad especial. Mencione especialmente a las niñas que participan poco o que son más reservadas. 


\section{Introducción del tema}

\section{Cuente al grupo la siguiente historia:}

Irma, Elbia, y Olga son buenas amigas y van juntas a la escuela. Esta mañana Olga y Elbia se extrañaron al ver que Irma no había llegado a clases. Ella siempre llega temprano y con ganas de estudiar. Sabían que sin Irma, no se reirían igual y el día sería aburrido. La primera clase del día era Ciencias Sociales y Olga pensó que para ayudar a Irma, le tomaría notas de la clase. Cuando terminó de copiar, Olga tuvo un problema: tenía dos hojas iguales y se empezaba a confundir entre lo suyo y lo de Irma. En ese momento fue cuando Elbia, que era muy ordenada, también ayudó. Ella le pidió a Olga las copias y las fue guardando a lo largo de todo el día, para entregarlas en orden y completas a Irma.

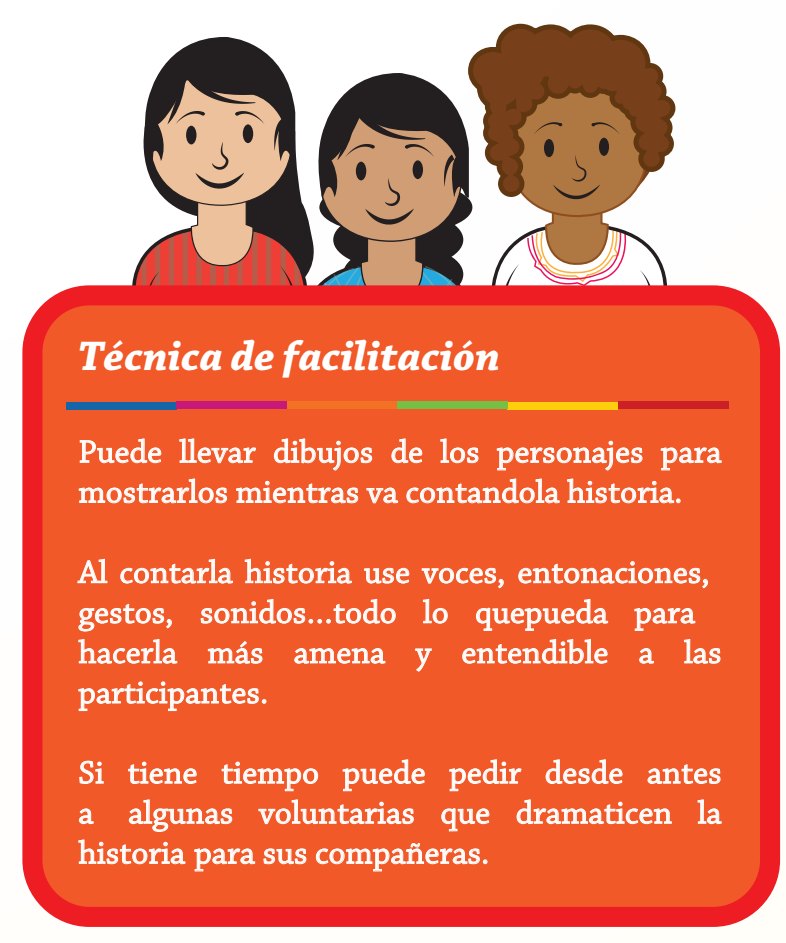

Mientras tanto, Irma estaba en su casa sintiéndose muuuuuy mal. Su mamá, muy buena cocinera, le estaba preparando un caldito y tortillas de prisa pues a medio llegaban las tías de Irma a la casa, para que ella se pueda ir a trabajar al comedor donde cocinaba. No sabían qué tenía. Irma se quejaba de mucha fiebre, dolor de estómago y mareos. Sabían que sí seguía así, tendrían que llevarla al Centro de Salud, y este está realmente está lejos y necesitarían transporte.

La tía de Irma que conocía a todas las personas de la Aldea porque era muy amable, se acercó a la casa de Don Juan, para contarle la situación de su sobrina. Don Juan sin dudarlo le ofreció llevarla en su picop al Centro de Salud, si fuera necesario, él era muy buen piloto y más para casos de emergencia. Intercambiaron números de teléfono y la tía de Irma le agradeció su amabilidad.

Lo bueno es que al pasar el día, Irma se sintió mejor y su cuerpo se levantaba. Recibió con muchos ánimos a Elbia y Olga que la visitaron por la tarde para dejarle las copias de la Escuela que le tomaron. Las tres amigas se sintieron felices de estar juntas y poderse ayudar unas a otras.

Reflexione con las participantes sobre la historia y la forma de relacionarse entre las personas. Pregunte a las participantes:

¿Qué fue lo que le pasó a Irma?

Se enfermó y no fue a la escuela un día.

$\checkmark$ ¿Qué extrañarían más las amigas de Irma durante su ausencia?

El ambiente divertido y cómo les hace reírse.

¿Qué fortaleza tení a Irma que le ayudaba a ganar los grados siempre?

Su puntualidad y deseo por estudiar 
- ¿Qué personas se preocuparon por ella durante el día?

Olga, Don Juan, Elbia, Mamá. Dibuje a las personas alrededor de Irma, puede hacerlo usted o pedir a algunas niñas que los pasen a dibujar rápidamente.

- ¿Qué relación tenía Irma con cada persona?

- Olga y Elbia: amigas de la escuela.

- Mamá y sus tías: parientes.

- Don Juan: vecino de la aldea.

- Escriba el parentesco a la par de cada personaje.

¿Qué fortaleza puso cada persona al servicio de Irma?

Olga: Buena para copiar

Elbia: Ordenada

Mamá: Buena cocinar

Tía: amable

Don Juan: Bueno para manejar casos de emergencia

¿A qué grupos de personas pertenece Irma?

Escuela (Olga y Elbia).

Familia (Tías y mamá).

Don Juan (Vecino de la aldea).

Puede hacer un círculo alrededor de Irma y los personajes para mostrar

cada grupo y cómo Irma pertenece a varios grupos que la apoyaron.

¿Cómo le ayudó a Irma ser parte de tantos grupos?

\section{Teorizar y definir:}

\section{Diga a las participantes:}

En la historia, cada persona es diferente porque tiene fortalezas y debilidades. La fortaleza es una característica positiva que tenemos, que nadie nos puede quitar. Una debilidad es una característica que nos dificulta y sentimos que no podemos hacer muy bien. En los grupos se identifican diferentes fortalezas y debilidades de las personas que lo conforma. Entre más compartamos nuestras fortalezas con los grupos a los que pertenecemos mejor vive y crece el grupo. Al igual que en la historia este grupo de Abriendo Oportunidades tiene fortalezas que vamos a compartir.

Entregue a cada participante un papel y dígales que se junten en parejas con una compañera que es su amiga. Es muy importante que TODAS tengan pareja. Pida que en el papel que tienen escriban tres fortalezas de la amiga con la que están, con el papel deben hacer una flor para entregar a su compañera. Al terminar la flor para su compañera 
regresan al círculo y cada una presenta a su compañera, comparte con el grupo las fortalezas que tiene y le entrega la flor que le hizo.

Mientras se presentan usted escribe en un papelógrafo todas las fortalezas que digan para ver la riqueza que tiene el grupo de Abriendo Oportunidades de la comunidad. Pregunta:

¿Cuáles ven queson nuestras principales fortalezas como grupo al que pertenecemos?

¿Qué podemosaportar a las mujeres de nuestra comunidad con nuestras fortalezas?

¿Quécambio podemos hacer en la comunidad con nuestras fortalezas?

Todas pasan a colocar sus flores dentro de un florero que diga Somos Abriendo Oportunidades.

\section{Aplicación a la vida:}

entregue a las participantes las hoja de trabajo “¿Quién soy yo? Mi Flor: Mis Fortalezas y Mis Debilidades”. Invite a las participantes a dibujar una flor con pétalos, tallo, y una plaga (gusanito) pequeña. En los pétalos las participantes pueden escribir o dibujar sus fortalezas y en el gusanito las participantes pueden escribir o dibujar sus debilidades.

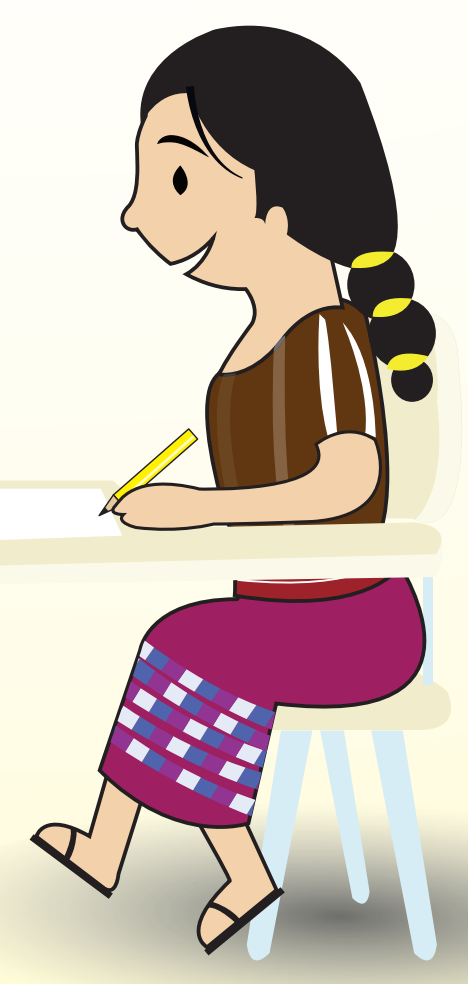




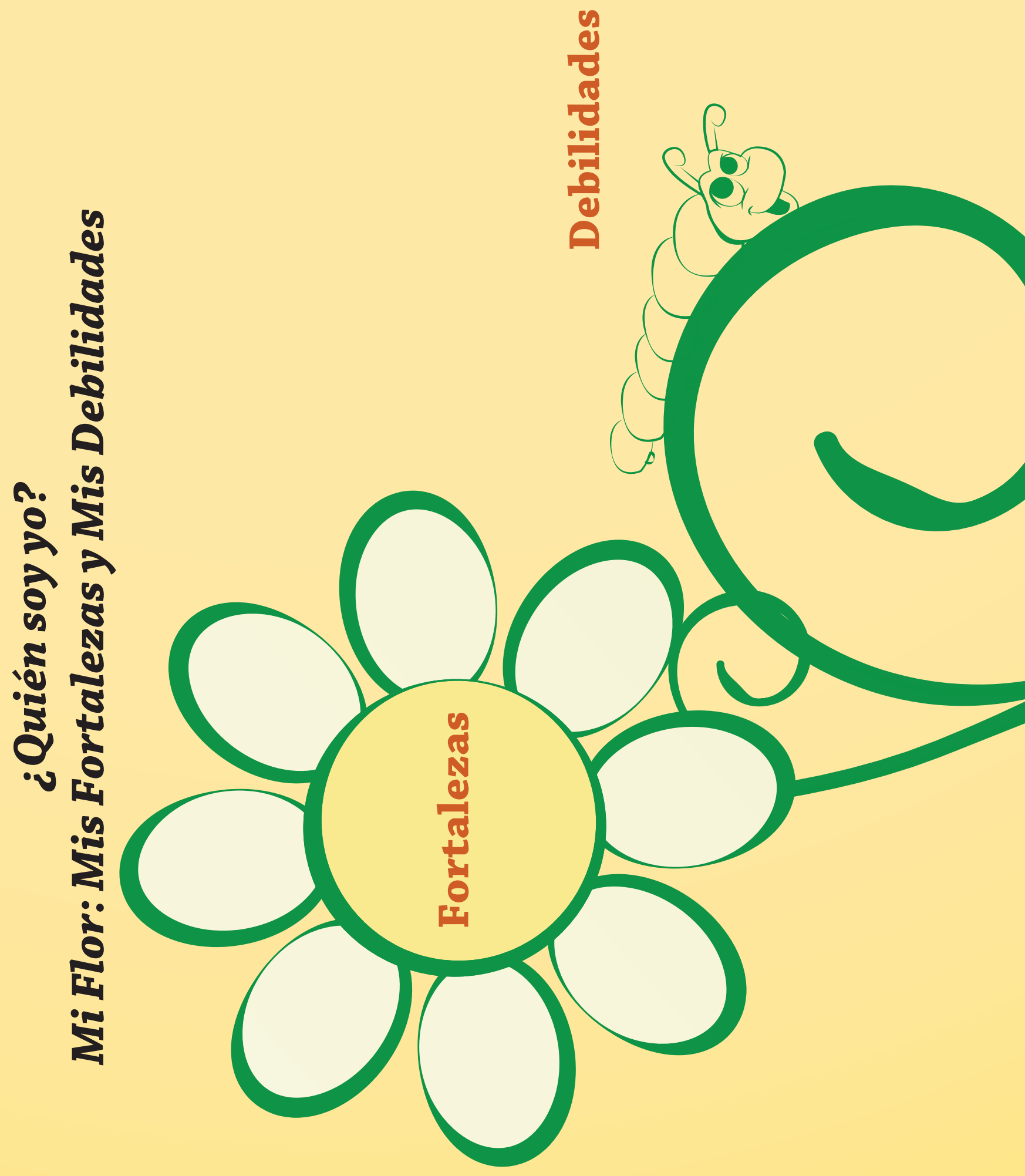




\section{Soy valiosa por ser quien soy}

$\begin{array}{ll}\text { Al finalizar } & \text { - Explorado sus sentimientos hacia sí mismas identificando que son valiosas. } \\ \text { la sesión las } & \text { - comprendido qué es el autoestima y cómo ayuda a las personas a desarrollarse. } \\ \text { participantes } & \text { - Identificado situaciones que afectan de forma negativa/positiva su autoestima y formas } \\ \text { habrán... } & \text { para cuidarla. }\end{array}$

\section{Conceptos Clave}

\section{Autoestima:}

Es la imagen y percepción que tiene una persona de sí misma, sobre la cual se valora. Se desarrolla en interacción con la familia, las amigas, la escuela, la iglesia, los medios de comunicación y todos los mensajes que le hablan sobre sí misma. La forma de verse y valorarse puede cambiar de un momento a otro durante la vida, afecta nuestro comportamiento con nosotras mimas y con las demás personas.

\section{Bienvenida}

De la bienvenida a las participantes. Verifique quién está presente y ausente. Pregunte por las ausentes para ver si las compañeras saben dónde están y qué pueden hacer para ayudarlas para que no dejen de llegar a las sesiones. Aproveche para platicar cómo han sentido las sesiones de encuentro y qué ha cambiado en ellas desde que están en Abriendo Oportunidades.

\section{Introducción del tema}

Pida a las participantes hacer una lluvia de ideas de todas las plantas que conocen (flores, árboles, arbustos, hierbas...) apunte lo que digan en un papelógrafo. Pida que se imaginen que ellas no son niñas sino que plantas y escojan cuál de esas es a la que más se parecen. Pensando en las diferentes características: su cuerpo, su forma de ser, su relación con otras niñas y personas, sus fortalezas, sus debilidades, sus ideas. 
Entregue una hoja de papel a cada participante y pida que dibuje la planta que ha escogido escribiendo las características por las que la escogió. Pida que se reúnan en grupos de 3 amigas y compartan su trabajo con su grupo. Contestando a tres preguntas:

1. ¿Con qué planta me comparo?

2. ¿Qué características tengo que me hacen compararme a la planta?

3. ¿Desde cuándo pienso que tengo estas características?

Luego pida que regresen en plenaria y pregunte a las participantes:

¿Qué fue lo más fácil de hacer este ejercicio?

¿Qué reacción tuvieron sus amigas a lo que ustedes les contaron de cómo se ven a ustedes mismas?

¿Alguna está en desacuerdo con la forma en que su compañera se describió a sí misma?¿Qué otra planta le hubiera puesto?

¿Qué experiencias de la vida son las que las han hecho verse a sí mismas como la planta que escogieron?

\section{Teorizar y definir:}

Entregue una hoja de papel a cada participante y solicite que cierren sus ojos e imaginen la historia que usted les narrará. Todas deben tener su hoja de papel y un lápiz a la mano. Cuénteles la siguiente historia:

¿Eres tonta? ¿No puedes hacer nada bien?

Una mujer dijo estas palabras a su hija pequeña solo porque se alejó de ella. Se las dijo tan recio que todos voltearon a verla y la niña se sintió mal y triste, regresó con los ojos llorosos al lado de su mamá. Pasando por una venta vio unos espejos y sin querer se vio a sí misma en el espejo.

¿Cómo crees que se sintió? ¿Qué vio cuando se miró en el espejo?

¿Cómo se vio a sí misma? ¿Qué piensa acerca de sí misma? 
Piensa en algún momento que te has sentido como la niña. Dibuja en la hoja de papel cómo crees que se ve la niña a sí misma cuando miró por el espejo. Puedes usar también palabras para describir sus ideas y sentimientos acerca de su aspecto físico, su relación con otras personas, sus fuerzas, su inteligencia.

Pida que dibujen de forma individual lo que imaginan en la hoja de papel. Siga diciéndoles:

De pronto la niña se cae al suelo y te acercas a ella para recogerla; le das un abrazo cariñoso y haces todo lo que puedes por consolarla, escucharla, ayudarla a sentirse bien consigo misma y a estar mejor. Te das cuenta que hay muchas cosas en común entre cómo se mira ella a sí misma y cómo te ves a ti misma. A veces es muy segura y feliz con ganas de hacer cosas alegres y aún cosas difíciles y otras veces no se cree buena, piensa que no sabe y que es débil $y$ tonta. Sin querer empiezas a contarle a ella veces que te han hecho sentir mal y otras veces que lo que haces te ayuda a sentirte bien contigo misma.

Pase un espejo grande entre las participantes y pida que se vean en silencio en el espejo y piensen acerca de las preguntas que les hizo. Pida que en el otro lado de la hoja dibujen cómo se ven a sí mismas, pueden usar palabras también para describirse.

\section{Técnica de facilitación}

De suficiente tiempo para que trabajen en sus retratos, pida que lo hagan de forma individual. Puede ponerles música suave de fondo.

Presente en un papelógrafo la palabra AUTOEstima. Platique con ellas por momento qué significan las dos palabras que componen dicha palabra (Autoestima) y qué significará el concepto. Apunte palabras clave que definan el concepto en el pizarrón. Diga a las participantes:

Ustedes han dejado plasmado en un dibujo cómo se ven a sí mismas y cómo se sienten consigo mismas. Eso es autoestima. Vamos a leer todas juntas un poco qué es autoestima.

Reflexione con las participantes acerca de cuándo han tenido experiencias que forman para bien o para mal su autoestima. Puede empezar por identificar en la historia cuándo la niña se sintió bien y cuándo se sintió mal. Diga a las participantes:

Todas las personas tenemos autoestima y la forma en que nos portamos unas y unos con otras también afectan el autoestima de las demás. A veces sin darnos cuenta afectamos el autoestima de las amigas.

\footnotetext{
¿Cuándo he visto que alguien afecta de forma negativa la autoestima de una mi amiga? Cuando hay chismes, cuando le hablan mal, cuando no la aceptan en un grupo, cuando no la dejan estudiar.
} 
¿Qué pasa cuando ella se siente mal consigo misma?

No puede hacer las cosas que quiere, le da miedo y no se atreve a probar sus habilidades. No se relaciona con las personas, puede ser más enojada y frustrada

¿Cómo me ayudas a mejorar la autoestima de otras mujeres de la comunidad?

Aceptarla en el grupo, tener buena comunicación, respetarlas, valorar a las mujeres que participan, no hacer chismes de otras mujeres, trabajar en equipo con ellas, compartir las dificultades y buscar soluciones juntas, decirle sus fortalezas y sus cualidades

\section{Aplicación a la vida:}

En la hoja de trabajo "Cómo me siento" contesten a las preguntas de los cuadros. En el círculo de la derecha, escriben algo que no las hace sentir bien de sí mismas. En la flecha del centro escriben qué van pueden hacer para cuidar sus sentimientos y cambiarlo. En el círculo de la derecha escriben qué les gustaría sentir acerca de sí mismas en ese aspecto. Hay 6 espacios pero ellas no tienen que usar todos los espacios. Revise que todas hayan comprendido el ejercicio, permita que trabajen individualmente. Mientras lo hacen puede pasar entre ellas para asegurarse que estén haciendo bien su trabajo y resolver algunas dudas que tengan.
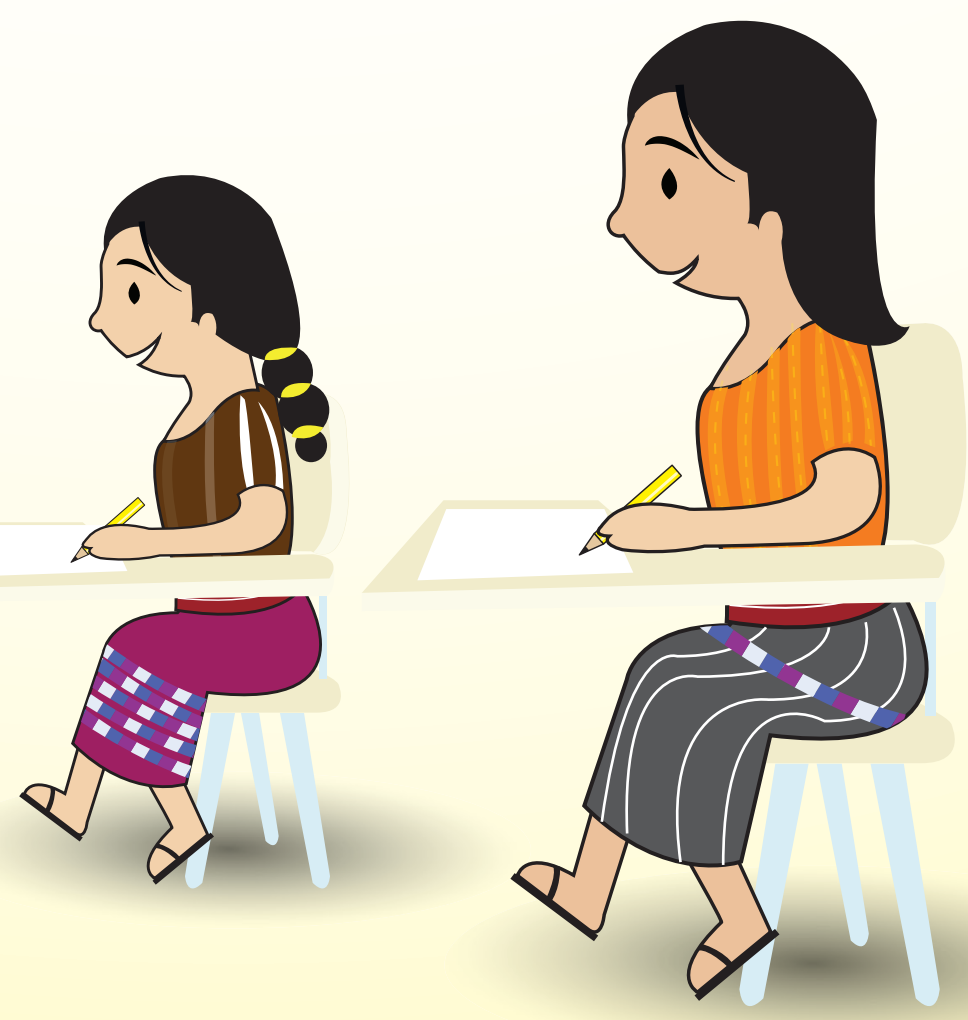


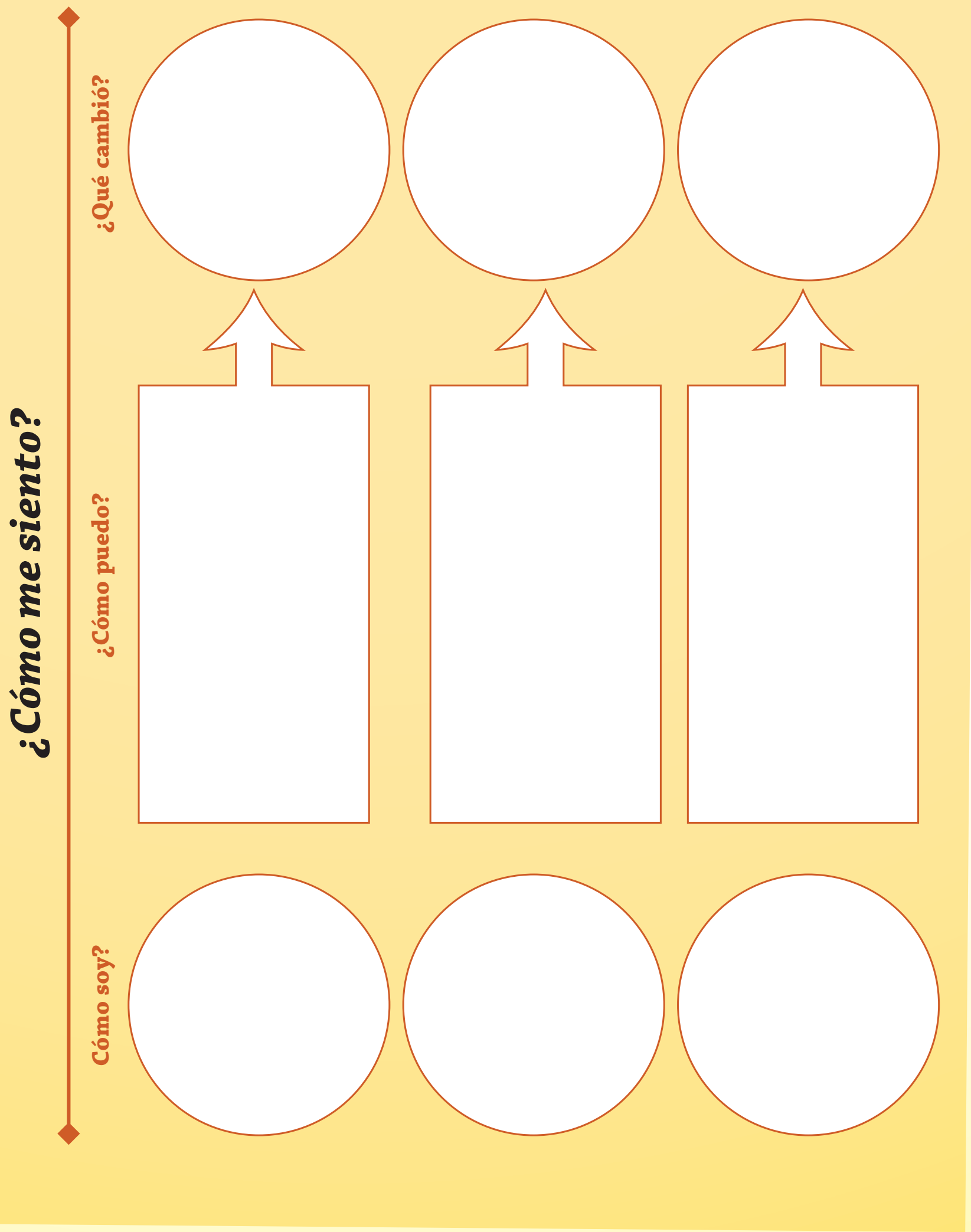




\subsection{Los derechos humanos valoran mi autoestima}

2 horas
Al finalizar
la sesión las
participantes
habrán...
- Conocido qué son los derechos humanos.
- Reconocido que todas las personas tienen que exigir, respetar y cumplir los derechos humanos propios y de los demás.
- Conocen que existen derechos específicos para grupos vulnerabilizados (Mujeres, indígenas y jóvenes)

\section{Conceptos Clave}

Derechos Humanos: condiciones de vida mínimas que todas las personas deben disfrutar para sí misma en su desarrollo como seres humanos, desde el momento en que nacen.

Responsabilidad: valor de cumplir voluntariamente con las obligaciones propias $y$ especialmente el cumplimiento del respeto a las demás personas.

Algunos derechos de la niñez:

Derecho a tener un nombre $\cdot$ Derecho a tener una familia Derecho a la educación. Derecho a la salud Derecho a la recreación. Derecho a la vivienda

\section{Derechos específicos:}

garantías que se han creado para atender necesidades especiales de grupos de personas que han sido discriminadas y obligadas a vivir en desventaja.

\section{Marcadores · Papelógrafos}

Imágenes de grupos de personas afectadas y desplazadas por el Conflicto

Armado Interno · Hoja de trabajo "Derechos Humanos Universales"

\section{Bienvenida}

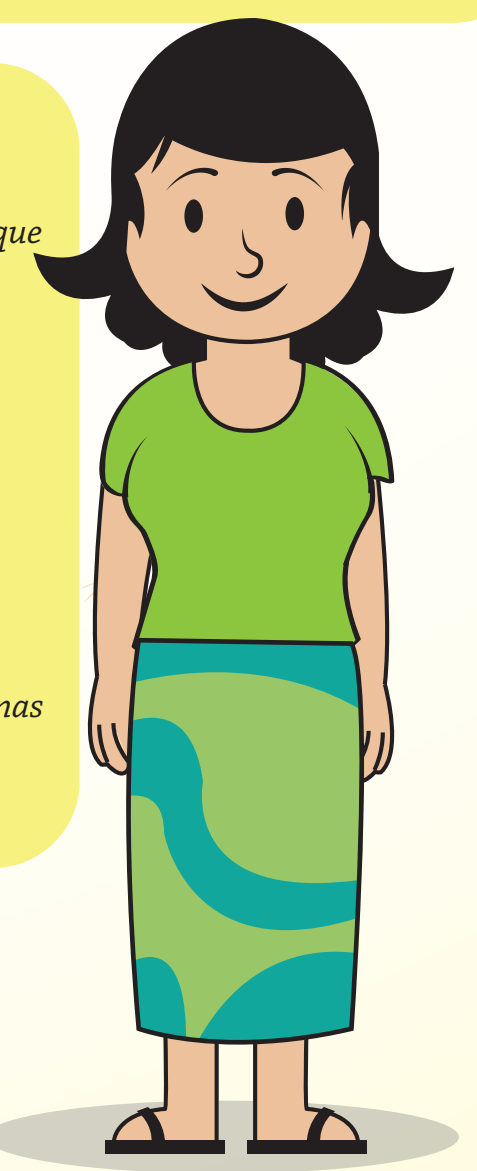

Dé la bienvenida a las participantes, confirmando quiénes están presentes o ausentes. Invítelas a salir a la puerta del Espacio Seguro y observar su comunidad, identificando qué cosas de la comunidad son muy importantes para su vida y la de su familia. Pueden compartir sus ideas desde la puerta.

\section{Introducción al tema:}

Coloque a las participantes en círculo y ponga en el centro varias imágenes de las comunidades desplazadas durante el Conflicto Armado Interno en Guatemala. Cuente que son imágenes reales de comunidades guatemaltecas hace unos treinta años. Deje que las vean, las intercambien, comenten sobre ellas etc. Mientras lo hacen diga a las participantes: 
Estas son imágenes de hace un treinta años en Guatemala cuando el país vivía un guerra en la que se cometieron muchísimas agresiones en contra de personas por su idioma, su cultura, su territorio, sus ideas sobre el gobierno y la comunidad y por los bienes que tenían. Para sobrevivir muchas comunidades tuvieron que irse de sus aldeas para vivir en la montaña sin recursos ni nada que llevar con ellas, allí estuvieron escondidas para que no las encontraran por temor a sufrir violencia.

¿Conocen historias de personas, familias o comunidades que tuvieron que huir del lugar donde vivían en estas condiciones y cómo era la vida para ellos?

¿Qué cosas son importantes para la vida de la comunidad en esas imágenes?

Forme grupos de 4 ó 5 personas, entregue un papelógrafo y marcadores a cada grupo. En sus grupos imaginan que son lideresas de una comunidad que se ha refugiado en la montaña. Como van a empezar una nueva etapa de la vida quieren asegurarse de que todas las personas tengan una buena vida, van a escribir diez condiciones que tienen que tener todos los habitantes de la comunidad para asegurar que sean felices y se puedan desarrollar. Pida que escriban las 10 condiciones en sus papelógrafos. Permita que trabajen durante 20 minutos y luego presentan su papelógrafo al resto del grupo.

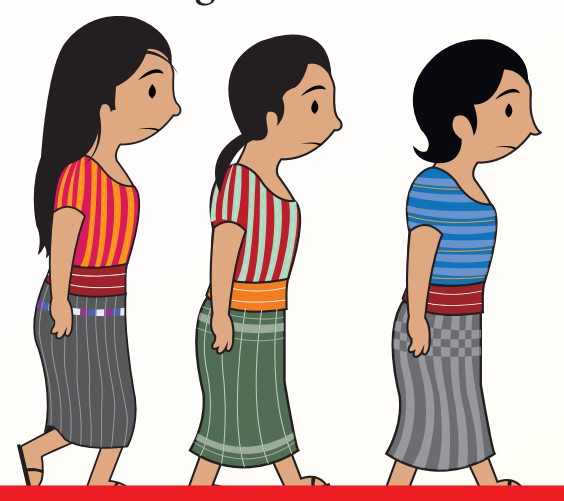

\section{Técnica de facilitación}

Cuando presentan subraye las condiciones que se repiten de un grupo a otro. Motive a que expliquen por qué consideran que esas condiciones son tan importantes.

\section{Teorizar y definir:}

Cuénteles sobre la II Guerra Mundial y cómo se pensaron en los derechos humanos. Diga a las participantes:

La guerra en Guatemala, el Conflicto Armado Interno, no fue la primera ni la única guerra de este tipo. Existió la II Guerra Mundial en la que varios países del mundo se pelearon entre sí y se dieron situaciones muy similares a las que se vivieron en Guatemala después. Al terminar la guerra en 1945 representantes de varios países se unieron para discutir sobre la que había pasado y decidieron que nadie querría que algo así volviera a pasar a nadie, pues todos los seres humanos tenían valor y dignidad por lo que debían ser respetados. Como un acuerdo entre todos los países escribieron la Declaración Universal de los Derechos Humanos, una lista de condiciones a la que todas las personas debian poder gozar para desarrollarse, participar libremente y vivir mejor, algo así como lo que acaban de hacer en sus grupos. Fue necesario declarar estas condiciones mínimas porque algunas personas con más poder se habian venido aprovechando de otras con menos poder y esta situación se sigue dando a la fecha.

Entregue a cada una la hoja de trabajo "Derechos Humanos Universales" lean juntas los derechos. Circulen en los papelógrafos las condiciones que están entre los derechos humanos. Para cada derecho pida que den un ejemplo de cómo sín se cumple o cómo no se cumple en la comunidad. Pregunte a las participantes: 
¿Qué similitudes encontraron entre la lista que hicimos y la Declaración Universal de los

\section{derechos humanos?}

¿Qué significa que esta declaración sea universal?¿A quiénes protege?

¿Qué grupos tienen más dificultad para hacer cumplir sus derechos humanos?

\section{Niños y jóvenes}

Mujeres

\section{Pueblos indígenas}

\section{Aplicación a la vida:}

Analice con ella las relaciones de poder en su comunidad y cómo estos afectan los derechos humanos. Entregue 12 papelitos de 6 colores diferentes entre las integrantes, pida que encuentren entre ellas a la que tenga papel del mismo color. Formarán así parejas de grupos sociales que tienen diferente relación de poder. Pida que las parejas presenten a sus compañeras los dos grupos que tienen. Luego todas juntas deben decidir cuál de los dos grupos tiene más poder y cómo se afectan los derechos humanos del grupo con menos poder.

Coloque los papeles en un papelógrafo que tenga tres columnas de la siguiente forma:

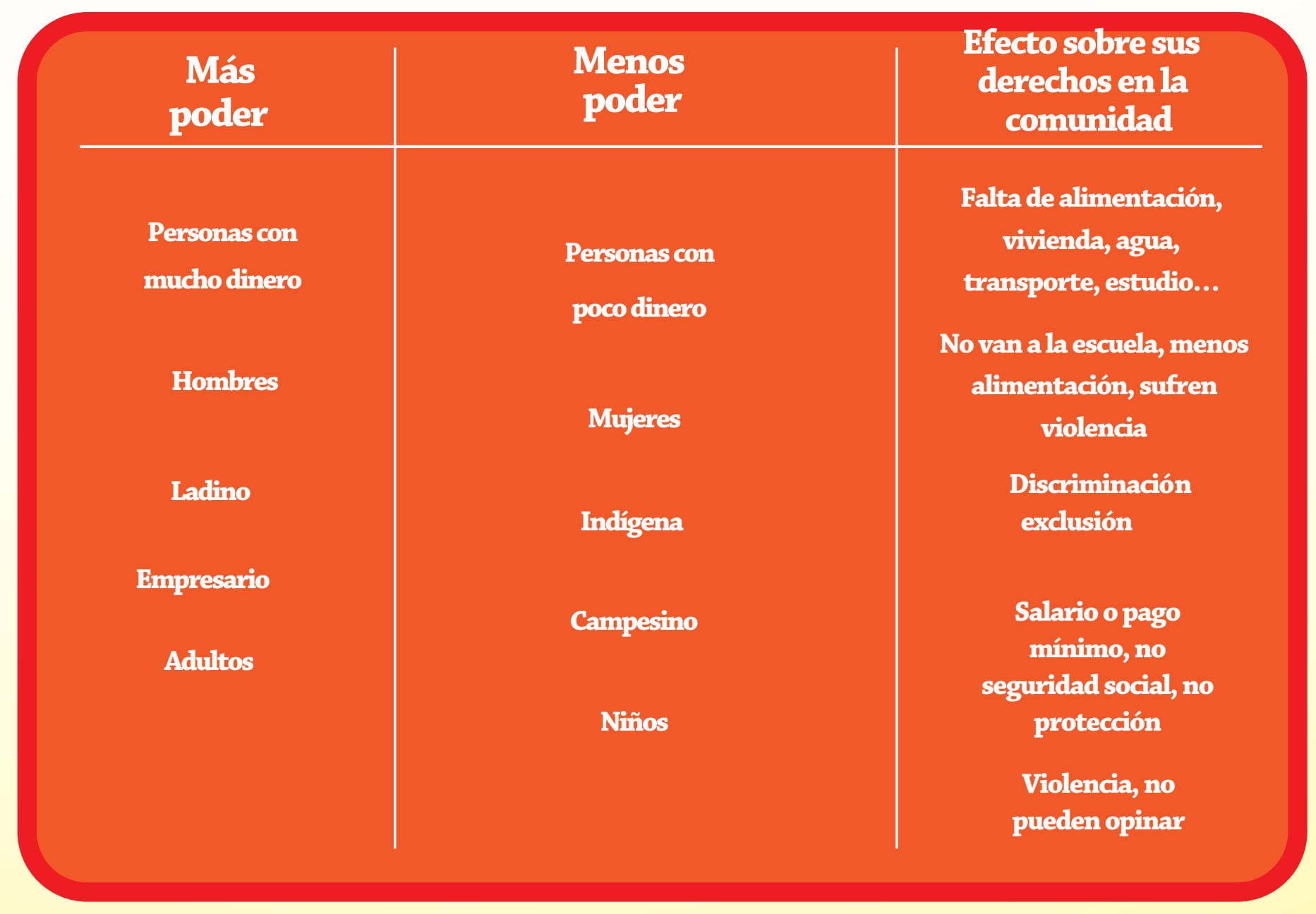

\section{Personas con discapacidad física}

\section{Enfermos}

relación de poder.
entre ellas a la que
ntas deben decidir 
Al terminar circule cuáles grupos necesitan derechos específicos que les protejan y pregunte:

\section{¿A cuáles grupos pertenecen ustedes?}

\section{Mujeres, jóvenes, indígenas}

¿Qué situaciones han vivido que evidencian su relación de poder con otros grupos?

¿Cómo Abriendo Oportunidades permites que esa relación de poder empiece a cambiar?

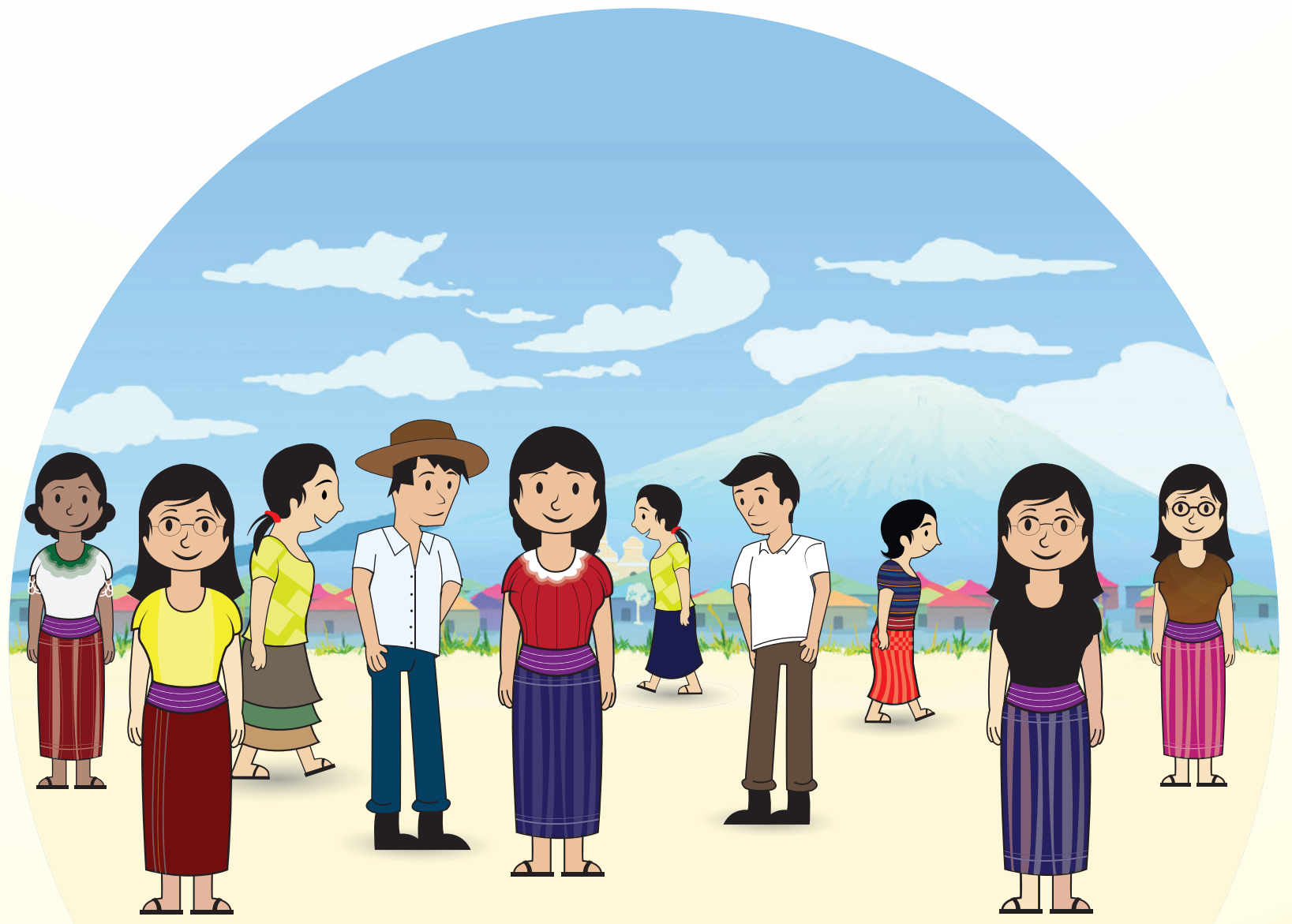




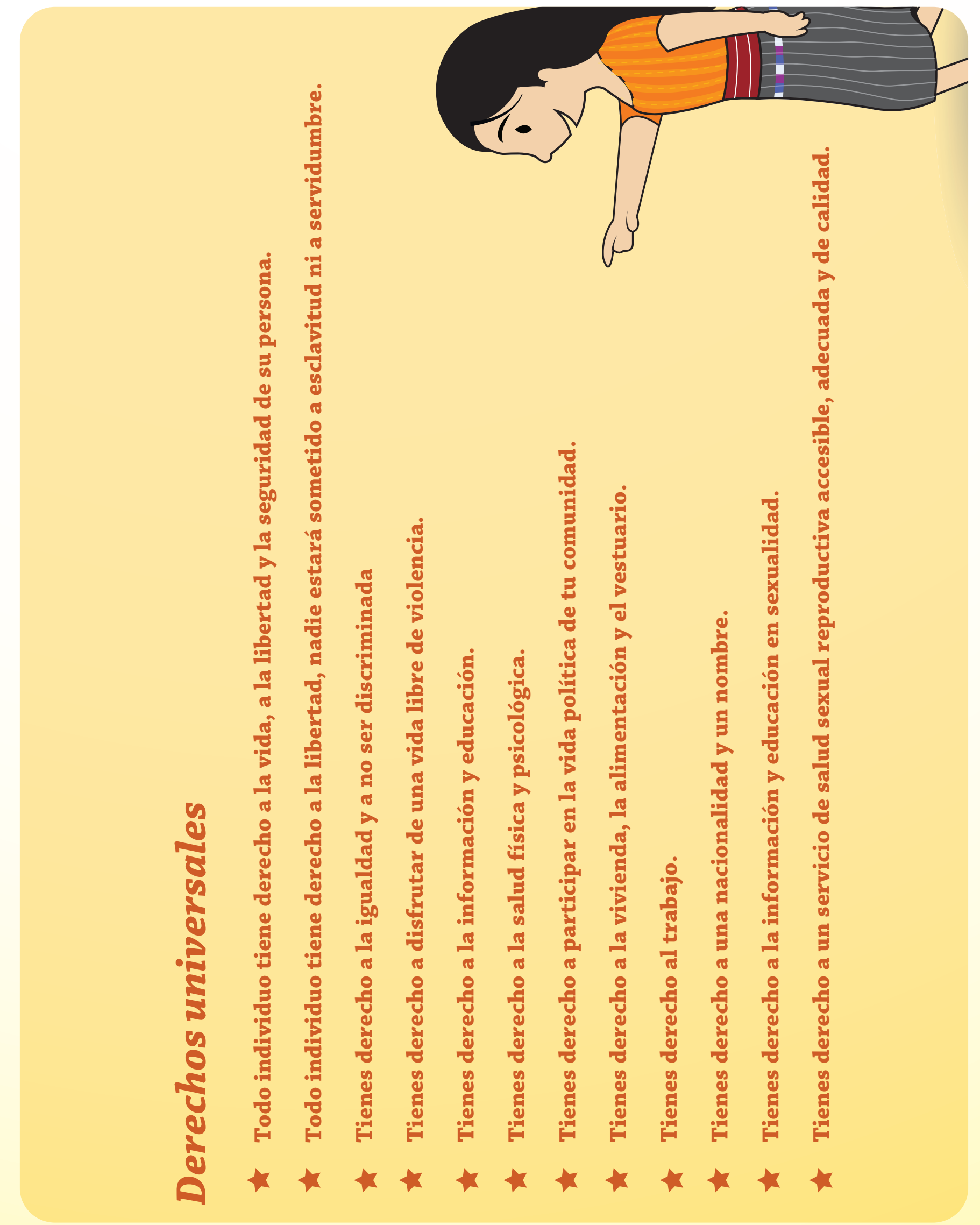



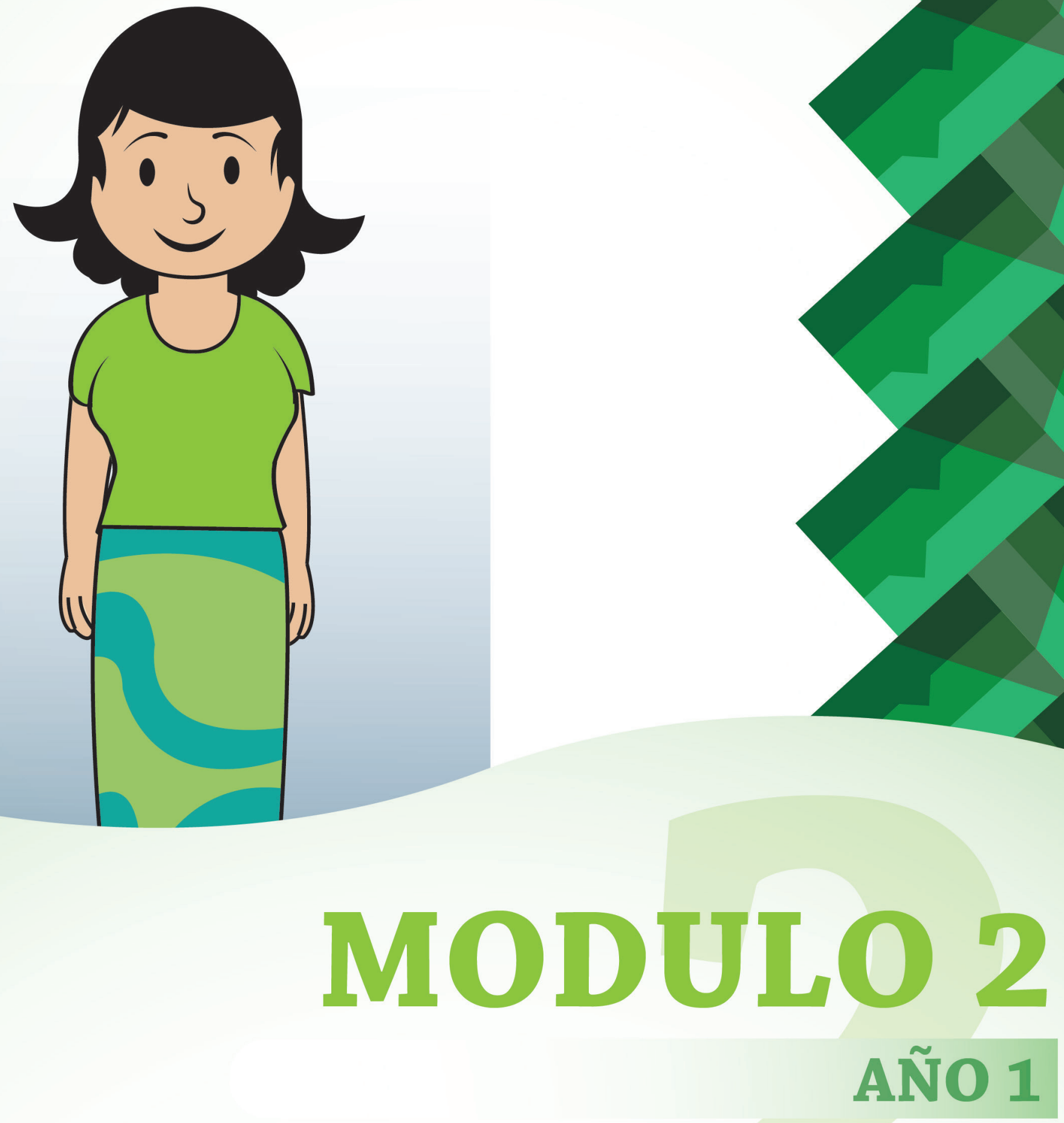

Guía Curricular Integrada 2015 - Population Council 


\section{Créditos}

- Autoras:

- María Cecilia Garcés de Marcilla/Especialista en Educación

$\checkmark$ Paola Broll / Oficial del Programa

$\checkmark$ Revisión: Alejandra Munguía/ Coordinador de Campo

- Diagramación:Isaí de la Cruz

- Equipo Population Council 2015:

$\checkmark$ Directora de Programas: Alejandra Colom

Supervisor de Monitoreo y Evaluación y oficial de Programa: Ángel del Valle

- Administradora: Ana Lucía Rodríguez

Mentoras: Elizabeth Vásquez, Claudia Macz, Sonia Chó, Patricia Alva, Maribel Gutiérrez, Fabiola Colop y Rosa Güit 


\section{AÑO 1 Módulo II}

El segundo módulo articula la educación financiera con el fortalecimiento personal como estrategia para fortalecer la capacidad de las niñas adolescentes de prevenir la violencia en su contra o hacia otras mujeres. Si bien la eliminación de la violencia es una responsabilidad compartida entre las organismos del estado, autoridades comunitarias y adultos/as se ha evidenciado que trabajar estas áreas complementariamente posibilita que las niñas y las adolescentes identifiquen, prevengan y se alejen de una relación potencialmente violenta.

\section{Grupo de 8 a 12}

2.1 Educación financiera: Doy para recibir

2.2 Educación financiera: Tengo que escoger la mejor opción

2.3 Prevención de violencia: Veo los peligros que tengo cercanos

2.4 Fortalecimiento personal: Mi familia me quiere y me puede apoyar

\section{Grupo de 13 a 17}

2.1 Educación financiera: Mis necesidades: la escasez y en qué gasto

2.2 Educación financiera: Justicia económica, poder y derechos

2.3 Educación financiera: La importancia de ahorrar

2.4 Educación financiera: Haciendo mi vida opciones de trabajo

2.5 Prevención de violencia: Yo me expreso asertivamente

2.6 Prevención de violencia: Reconozco cuándo y dónde estoy en peligro 
Al finalizar

la sesión las participantes habran...
- Comprobado que las cosas no son gratis y la satisfacción de algunas de sus necesidades demandan recursos financieros

- Identificado que a través del trabajo sus familias, vecinos, vecinas, y ellas producen bienes y servicios que intercambian para satisfacer necesidades.

- Comprendido el proceso de intercambio en la comunidad.

- Mencionado momentos en que son productoras ó consumidoras.

\section{Conceptos Claves}

Bienes:

Cosas materiales que se produce a través del trabajo.

Trabajo:

El esfuerzo que se realiza para producir un bien o recibir un pago que permita satisfacer las necesidades $y$ deseos.

\section{Servicios:}

Actividades que se realiza para la satisfacción de necesidades de otras personas atender enfermos, dar clases, transportar personas...

Intercambio:

Acción de dar y recibir bienes y servicios libre y voluntariamente.

\section{Materiales}

- Dibujos de las escenas 1-4 de la historia

- Flechas, estrellas o círculos de papel

- Crayones

- Hoja de trabajo "Mujeres que mueven la economía"

\section{Bienvenida}

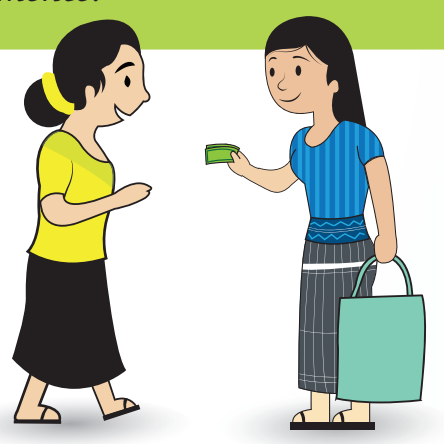

Dé la bienvenida a las participantes, confirmando quiénes están presentes o ausentes.

Invítelas a jugar "La Ratoncita Pide". En este juego hay una ratoncita que le gusta llevarse las cosas a su madriguera, siempre está pidiendo y pidiendo cosas. La mentora jugará a ser la ratoncita y las niñas formarán dos equipos. Cuando la mentora diga lo que quiere la ratoncita, cada equipo buscará entre ellas y sus cosas lo que se les pide y se lo llevarán lo más rápido que puedan. Algunas de las cosas que la mentora puede pedir son:

Algo que su mamá les compró en el mercado

Una cosa que ellas o su familia elaboraron para sí mismas

Un recurso que pueden usar para comprar otra cosa

Algo que necesitan para vivir bien y mantenerse saludables 
Al poner todas las prendas al frente platique con ellas de dónde han obtenido las cosas que encontraron. Pida a tres participantes que compartan de dónde vienen algunas de las prendas de ropa que están usando. Fíjese que sean cosas que requieren de hacer una compra o intercambio (suéter, zapatos, faja, corte, güipil, etc.). También van a platicar sobre la importancia del intercambio que sucede todos los días en el que siempre damos algo y recibimos algo.

\section{Introducción del tema:}

Mientras se narra la historia vaya pegando los dibujos de cada escena a la vista de todas las participantes:

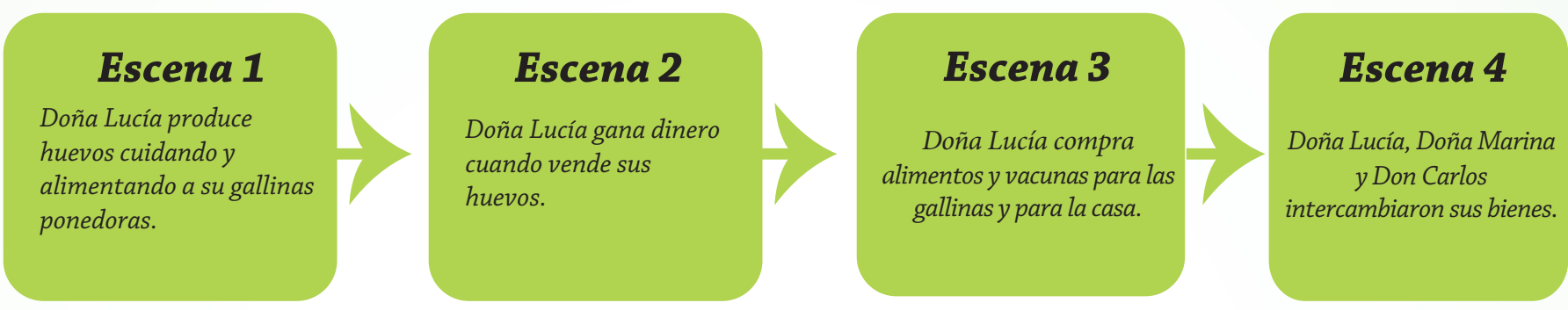

\section{Historia: "Cambalache"}

Doña Lucía tenía un negocio de gallinas ponedoras y vendía huevos. Un día Don Carlos le pidió que le vendiera doce huevos y ella con gusto se los vendió. Con el dinero de la venta, Doña Lucía agarró camino al mercado a comprar alimentos para su familia y a la tienda de Doña Marina para comprar papel higiénico y vacunas para las gallinas para que no se enfermaran. En la tienda Doña Marina la recibió feliz de verla y le vendió todos los productos a buen precio, así se asegura que Doña Lucía vuelva a regresar. Al final del día, Don Carlos se comió los 12 huevos con su familia, Doña Lucía compró lo que necesitaba para las gallinas y Doña Marina hizo un guardadito con el dinero de lo que vendió para el pago de la medicina de su mamá.

\section{Teorizar y definir}

Haga las siguientes preguntas y vaya señalando las respuestas en los dibujos de las escenas. Puede usar flechas, estrellas, ruedas u otras figuras para resaltar los conceptos clave:

¿Quiénes son los personajes de la historia?

¿Cuál es el trabajo de Doña Lucía?

cuidar la producción de huevos

¿Qué vendió Doña Lucía a Don Carlos?

Huevos

¿Qué necesidad tenía Don Carlos?

Huevos para comer con su familia

¿Qué intercambió Don Carlos con Doña Lucía por los huevos?

Dinero

¿Qué servicio ofrecía Doña Marina a Doña Lucía?

Venta de productos en la tienda 
¿Cómo ayudó el trabajo de Doña Marina a la salud de su mamá?:

La venta le permitía guardar dinero para las medicinas.

¿Cómo crees que se sentían los personajes al terminar el día?

Explíqueles que en algunos momentos somos productores, trabajadores y en otros somos consumidores. Al realizar un trabajo somos productores y recibimos dinero para producir bienes y/o servicios; al pagar un servicio o comprar un bien somos consumidores.

¿Cuándo es Doña Marina trabajadora?

¿Cuándo es consumidora?

\section{Aplicación para la vida:}

Entregue a las niñas la hoja de trabajo "Mujeres que mueven la economía" Invitelas niñas a que en una hoja dibujar a una mujer de su familia o de su comunidad que es trabajadora, productora y consumidora. Al terminar su dibujo lo compartirán con las demás comentando:

¿Quién es la mujer que dibujó?

¿Qué trabajo hace?

¿Qué produce?

¿Qué recibe a cambio de lo que produjo o de su trabajo?

¿Qué hace con el dinero que gana de la venta?

¿Cómo aprendió a hacer su trabajo?

Platique con las niñas sobre el esfuerzo que lleva hacer cosas para vender y que se necesitan conocimientos y recursos para comprar los materiales que luego se transforman en el producto final.

Pregunte a las niñas cuáles son los principales trabajos y productos de su comunidad y cómo estos satisfacen las necesidades de otras personas y comunidades.

Dialogue sobre como en la familia todos tienen responsabilidades y muchas veces las mujeres hacen trabajos aunque no reciban dinero a cambio de lo que hacen. Pida que den ejemplos de esto.

Pregunte y apunte las respuestas en un cartel:

¿Qué trabajos hacen las mujeres y las niñas en casa y en el campo?

Apunte las respuestas en un papelógrafo y solicite que subrayen los que se hacen sin recibir un pago ni nada a cambio.

¿Qué podemos hacer nosotras para cuidar las cosas que usamos y tenemos gracias al trabajo de nuestra familia, comunidad y medio ambiente?

Platique con las niñas para que analicen y valoren los esfuerzos que realizan al estudiar. Coménteles que lo que aprenden hoy, les servirá mañana para producir e intercambiar bienes y servicios para satisfacer sus necesidades.

¿Qué cosas de las que aprenden hoy pueden servirles para producir en el futuro?

Por ejemplo: mencionar las manualidades que han trabajado. 


\section{Mujeres que mueven la economia}

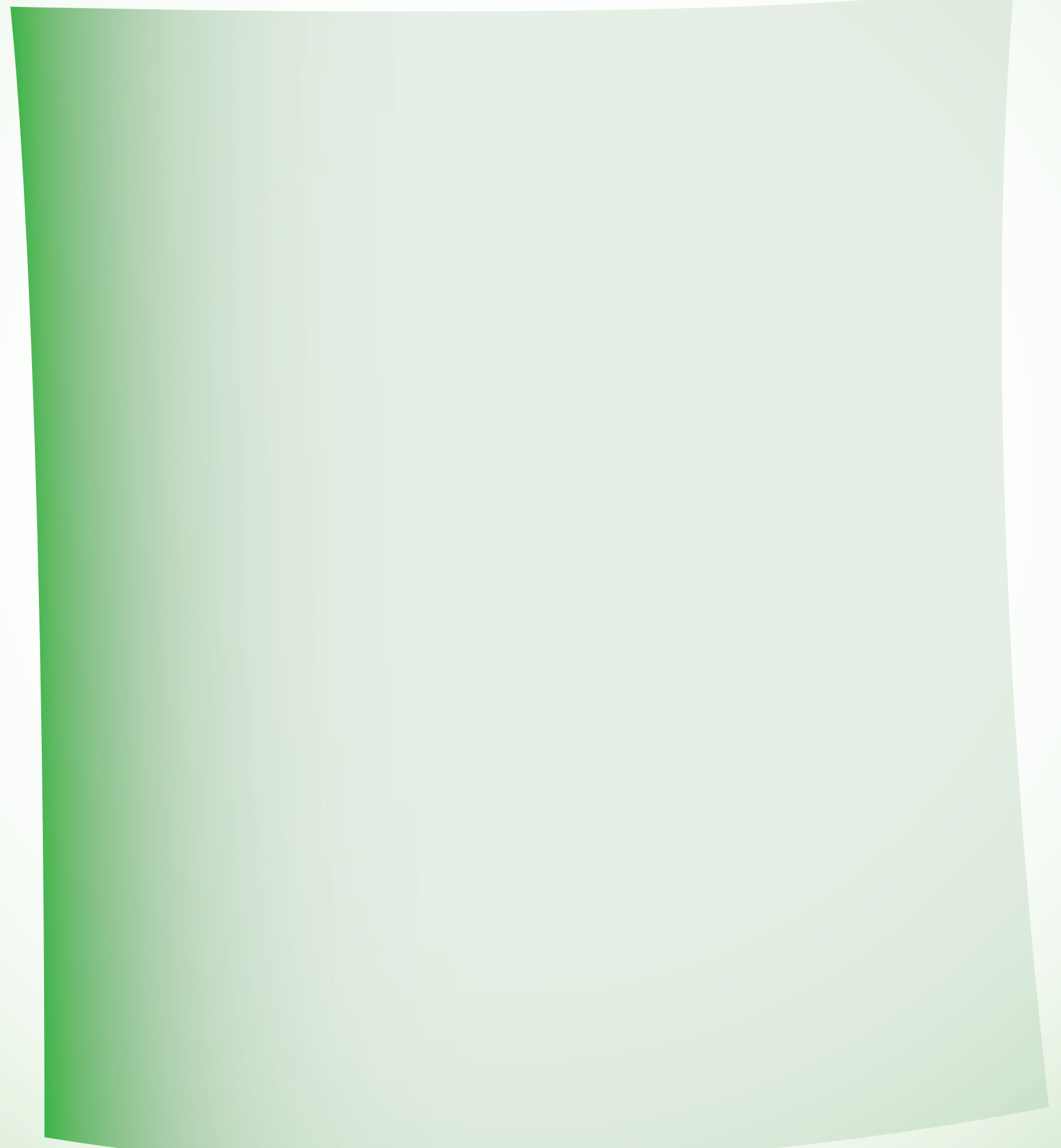




\section{Al finalizar la sesión las participantes habran...}

- Distinguido entre necesidades y deseos.

-Seleccionado las necesidades sobre sus deseos.

- Valorado la utilidad y el esfuerzo de ahorrar.

-Propuesto estrategias para ahorrar recursos y dinero.

\section{Conceptos Clave}

Necesidad: lo que se debe tener para vivir de forma digna y saludable, puede ser material o inmaterial.

Deseo: bienes o servicios que se ansían sin que satisfagan alguna necesidad básica.

Utilidad: : Cualidad que tiene un bien o servicio para satisfacer una necesidad.

Selección: Capacidad de escoger entre una cosa u otra cosa según su utilidad de acuerdo con las necesidades y deseos.

Presupuesto: Planificación de ingresos y gastos

Satisfacción: resultado de dar cumplimiento a una necesidad o deseo.

Ahorro: dinero y/o recurso que se preserva sin ser consumido para acumularlo con otros similares que sea de gran utilidad para tener mayor capacidad de consumo.

\section{Bienvenida}

Dé la bienvenida a las participantes, confirmando quiénes están presentes o ausentes. Comparta con ellas que el día de hoy van a escoger entre varias opciones. Solicite que le den ejemplos de cosas que han escogido esta semana.

\section{Introducción del tema:}

Empezarán jugando "Escoge para que el clima no te moje". Cinco voluntarias del grupo pasarán al centro. Cada una tendrá uno de los siguientes objetos: nylon, cubeta, periódico, petate, canasta. La mentora va a decir el pronóstico del clima y todas las participantes deben escoger ir con una de las cinco voluntarias según el objeto que tiene. Algunas de las predicciones de clima que puede decir la mentora son:

1. El cielo está gris, el aire empieza a soplar, la lluvia está cayendo. iiiNo me quiero mojar!!!

2. El sol está muy fuerte, casi no puedo ni verte, mi piel se empieza a quemar. iiiCon algo me tengo que tapar!!!

3. El aire sopla tan rápido que siento que puedo volar, tengo mucho frío iiiCon esto me puedo abrigar!!!

4. No quiero el cielo su agua soltar, la pobre planta se va a secar. ¡iDime tú con qué me ayudo para regar si no tengo un tubo!!! 


\section{Teorizar y definir}

Platique con las niñas que desde pequeñas tomamos decisiones, escogemos entre las opciones que hay. Elegimos qué comer, a qué jugar, si venimos al grupo o no. Cada vez que escogemos es una oportunidad para cuidar nuestros recursos y ahorrar. Pida que definan juntas qué es elegir y escriba las ideas acertadas en un papelógrafo. Luego que definan qué es una necesidad y escriba las ideas acertadas en un papelógrafo. Finalmente qué es un deseo y escriba las ideas acertadas en un papelógrafo.

\section{Aplicación para la vida:}

Forme cuatro grupos entre las participantes. Entregue a cada grupo una de las historias, pida que la lean y planifiquen una dramatización de la historia para presentar a sus compañeras.

\section{Historias}

\section{GRUPO 1}

Juana fue a la escuela y le dejaron de tarea hacer un cartel de las partes de la planta. Ella vio que tenía necesidad de comprar cosas para hacer su cartel, pensó en comprar papel, lana, goma, tijeras, brillantina, plasticina, cartón de colores. Cuando le pidió dinero a su mamá sólo le dio Q2.00, en la librería no le alcanzaba para todo lo que quería comprar. Juana escogió lo más importante: papel, tijeras y goma. Con esas tres cosas logró hacer su tarea lindísima.

\section{GRUPO 2}

En la mañana Fabiola acompañó a su papá al pueblo, comprarían cosas para preparar la siembra. En el pueblo había tantas, tantas, tantas, tantas cosas para comprar y eran lindas todas. Fabi empezó a pedir y pedir a su papá y él se las compraba. Al final no pudieron comprar todo para la siembra y solo lograron cosechar la mitad.

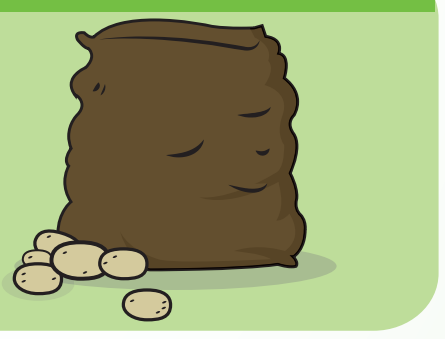

\section{GRUPO 3}

La mamá de Sonia tenía gripe y fueron a la farmacia del pueblo a comprar una medicina. Estando allí, les ofrecieron dos opciones una caja que costaba Q5.00, que era colorida, con letras bonitas y una foto de una señora linda que se sentía muy bien. También le ofrecieron otra caja blanca sin colores, con letras sencillas y sin fotos, que costaba Q1.00. La encargada de la farmacia les aseguró que los dos productos eran igual de buenos, la diferencia era el nombre y el empaque. La mamá de Sonia compró la caja blanca y con lo que le sobró, hizo un ahorro para la próxima enfermedad.

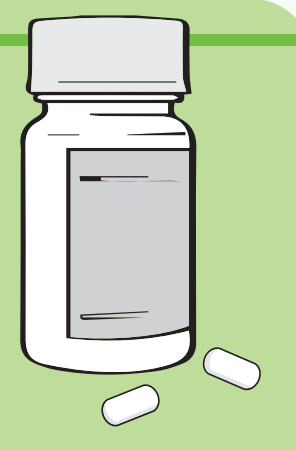




\section{GRUPO 4}

Un día Julia acompañó a su mamá a la tienda, tenían Q40.00 para comprar pollo, verduras y arroz prepararían un almuerzo sabroso. En la tienda Julia vio unos listones de colores brillantes lindos y le pidió tanto a su mamá que se los comprara que al final la mamá se los compró. Entonces no compró suficiente pollo y en el almuerzo el caldo

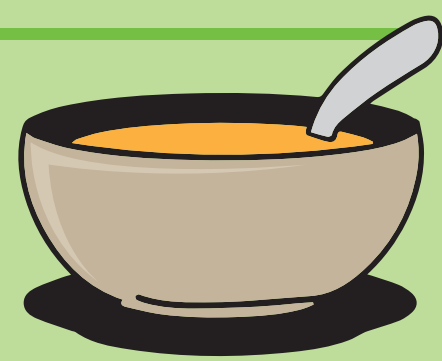
fue de verduras, arroz y poquito pollo.

(b) Dé 10 minutos a los grupos para que lean y planifiquen su dramatización. Luego deben presentarlos al grupo.

\section{Después de cada presentación pregunte:}

¿Qué necesitaban comprar?

$\checkmark$ ¿Qué deseo tenían?

¿Entre qué opciones tuvieron que escoger?

- ¿Escogieron por su necesidad o por su deseo?

¿El resultado fue dañino o les fortaleció? 


\subsection{Veo los peligros que tengo cercanos}

Al finalizar la sesión las participantes habran...
- Identificado los lugares de riesgo en su comunidad.

- Evaluado qué comportamientos las pueden poner en peligro.

- Pensado en estrategias a implementar para prevenir peligros

\section{Conceptos Clave}

Lugar de riesgo:espacio en el que puede suceder algo que produzca un daño físico, emocional, psicológico o de cualquier otro tipo. No hay personas que ofrezcan protección ni apoyo.

Comportamiento riesgoso: aquellas acciones que ponen en peligro el bienestar de la persona, propiciando el sufrimiento de algún tipo de daño.

Prevenir: acciones pensadas que evitan el riesgo de daño al bienestar de la persona.

\section{Bienvenida}

Dé la bienvenida a las participantes, confirmando quiénes están presentes o ausentes. Reparta a cada niña un papelito y pida que dibuje cómo se siente cuando está en el Espacio Seguro de Abriendo Oportunidades. Pasan a compartir sus respuestas, colocándoselas en el corazón. Dialogue con ellas porqué se sienten así y qué cosas han aprendido en el tiempo que llevan de estar asistiendo.

\section{Introducción al tema:}

Coloque a la vista de todas, el mapa de la comunidad con el que han trabajado y pregunte: ¿Además del espacio seguro en qué otros lugares de la comunidad se sienten seguras?

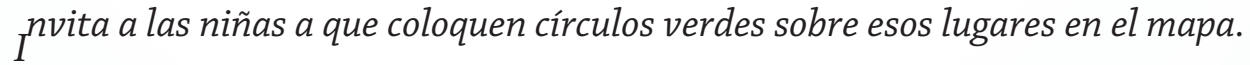

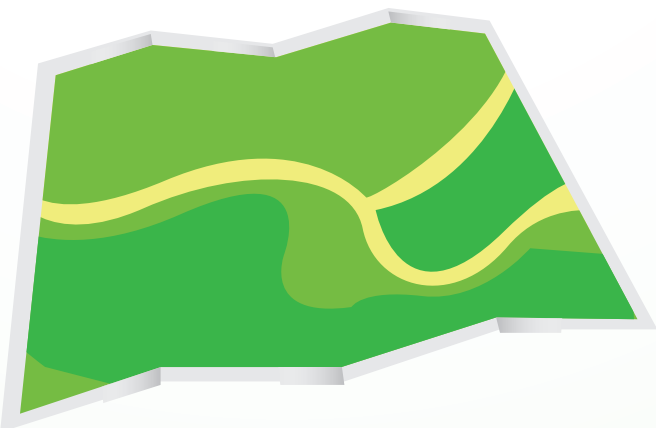

Comparta con ellas que para estar seguras es importante conocer los lugares de la comunidad para saber a dónde ir según las necesidades que se tengan o para hacer los mandados que son necesarios. Conocer los lugares significa no sólo saber en dónde quedan, sino que también conocer qué pasa en esos lugares, qué personas van allí, les gusta a ustedes ir allí o no, cómo las reciben y tratan cuando van a esos lugares. De acuerdo a toda esa información las niñas y jóvenes toman decisiones inteligentes sobre los lugares a los que van y a cuáles no. 
Coloque el mapa al alcance de las participantes, pida que dibujen todos los lugares de la comunidad que conocen en el mapa. Puede dividirlas en grupos y a cada grupo asignar un cuadrante de la comunidad. Al terminar ponga a la vista de todo el grupo el mapa completo.

\section{Pueden dibujar:}

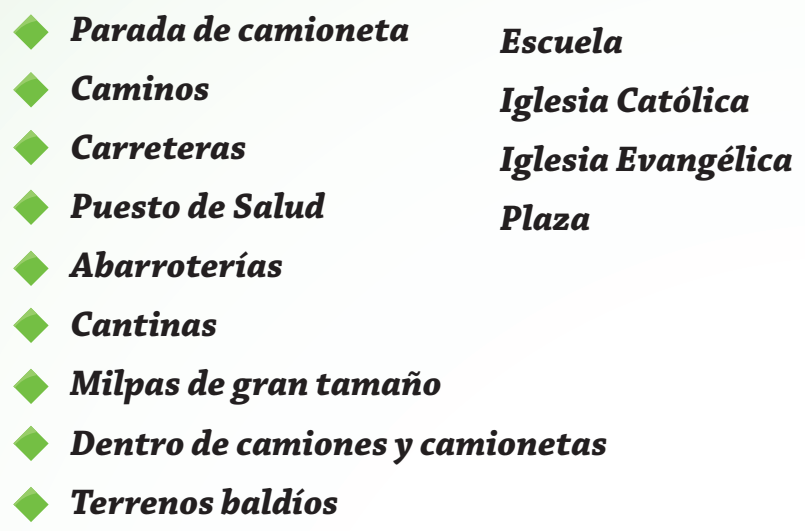

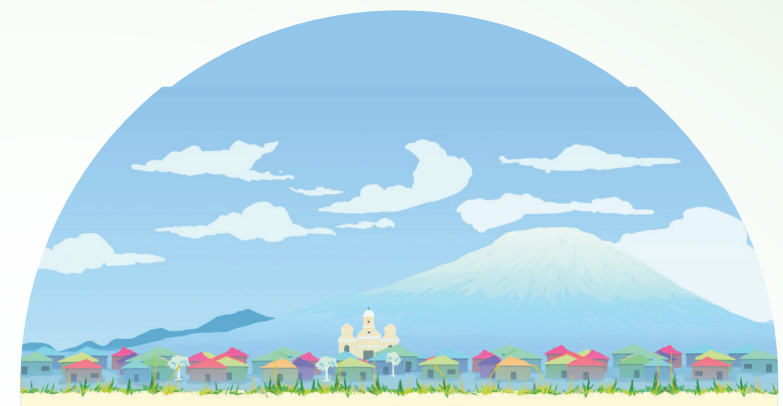

\section{Teorizar y definir:}

Lea el concepto de lugar peligroso con el grupo. Pida que discutan e identifiquen el grado de seguridad de cada lugar. Si es seguro colocan un círculo verde, parcialmente seguro círculo amarillo, totalmente inseguro círculo rojo.

Lea a todas la definición de conducta peligrosa y prevención de riesgos, pida a las participantes a dar ejemplos de cada tipo de conducta. Debajo de cada definición apunte los ejemplos que le dan.

Coloque una lana roja en el suelo todas se deben colocar sobre la lana roja. Pida que escuchen la lista de conductas que usted va a decir y si es de riesgo que salten para atrás pero si es de prevención salten hacia adelante. Luego de cada conducta deben regresar al punto del centro. Conductas para el juego:

- Ir acompañada de una amiga cuando va caminar por caminos solitarios.

- Ir a la abarrotería solita por la tarde-noche a comprar un dulce.

- Hablar con personas que no conozco pero parecen amables.

Dejar dicho en mi casa a dónde voy, con quien voy y cuánto tiempo voy.

Decir que voy al mercado pero después cambiar de lugar sin avisar a nadie.

\section{Aplicación a la vida:}

Van a reunirse en parejas y a cada una le tocará uno de los lugares que han identificado como riesgoso. Deben pensar en una conducta de riesgo pero en dos estrategias de prevención por si tienen que pasar cerca o ir al lugar que les correspondió. Puede formar grupos según la cantidad de lugares de riesgo identificados. Luego deben compartir con sus compañeras. Haga una lista de las conductas de prevención que enlistaron. 


\subsection{Mi familia me quiere y me puede apoyar}

\section{2 horas}

Al finalizar

la sesión las

participantes

habran...
Mencionado porqué les gusta asistir a Abriendo Oportunidades.

Identificado el apoyo que han recibido de parte de su familia para participar en Abriendo Oportunidades.

Expresado a su familia lo que aprecian de Abriendo Oportunidades y agradecen el apoyo que reciben de casa.

\section{Conceptos Clave}

Familia: Grupo de personas con quienes se comparte la residencia, se desarrollan relaciones de confianza, de cariño.

El grupo protege a sus integrantes y apoya su desarrollo.

Apreciar: Sensación de agrado por aquellas cosas que nos hacen bien y nos ayudan a crecer.

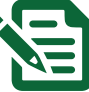

Hoja de papel por cada niña, papelógrafo y marcadores,

trabajos elaborados por las niñas - manualidades-

\section{Bienvenida}

Dé la bienvenida a las participantes, confirmando quiénes están presentes o ausentes. Comparta con ellas que el día de hoy van a empezar jugando un juego que enseña la importancia de trabajar unidos y estar bien comunicadas.

\section{Introducción del tema:}

Invite a las participantes a hacer la dinámica del Nudo Humano. Se ponen en un círculo cerca unas de otras y todas colocan las manos al centro, tomándose unas a otras en desorden. Luego deben buscar la forma para soltarse del grupo sin soltarse de las manos en ningún momento.

Al finalizar pregunte:

¿Qué quería lograr todo el grupo?

¿Cuál era la dificultad que tenían?

¿Qué hicieron para poderse soltar?

¿Cómo les ayudó poder hablarse entre ustedes y darse ideas?

$\checkmark$ ¿Qué cosas que han aprendido en Abriendo Oportunidades les han ayudado en su vida?

$\checkmark$ ¿Cómo les ha ayudado su familia a seguir participando en Abriendo Oportunidades?

$\checkmark$ ¿Qué beneficios ofrece a la familia cuando hay comunicación entre sus integrantes? 


\section{Teorizar y definir:}

Hable con ellas sobre la importancia de reconocer cuando uno recibe algo que le ayude y la importancia de agradecer para que pueda seguirse dando el apoyo. Diga:

La comunicación en un grupo es muy importante para que todos los integrantes del grupo alcancen sus metas y se sientan felices. Aqui en Abriendo Oportunidades ustedes encontraron un lugar seguro al que pueden venir a platicar, preguntar, aprender, jugar, hacer manualidades etc. que les sirven para tomar mejores decisiones en su vida. Vamos a pensar por un momento en todas las actividades que hemos hecho en nuestro espacio seguro en Abriendo.

Invítelas a acercarse a una pared en donde usted tenga expuestos los carteles que han usado o algunos de los trabajos que ellas han hecho a lo largo del año y que peguen una estrella con su nombre en la actividad que más les ha gustado.

Forme grupos de tres participantes. Pida que en sus grupos compartan cómo fue la reacción de sus familias cuando empezaron a ir al grupo y cómo es ahora. Pueden contar historias. Pedir que una de cada grupo comparta cómo ha cambiado el apoyo de las familias al programa. En un papelógrafo tome nota de lo que dicen.

Diga: Muchas veces nuestra familia se preocupa por nosotras y si nos conocen, saben qué queremos hacer, qué nos gusta y qué nos interesa. Es importante hacer dos cosas, contarle a nuestra familia acerca de nuestra vida y también agradecerles cuando nos apoyan en algo que nos gusta y nos hace crecer. Vamos a hacer también una lista de las cosas que hace nuestra familia para apoyarnos y las escribiremos en este cartel.

Escriba en un papelógrafo lo que las niñas le comparten sobre la forma en que su familia les ayuda a seguir yendo a Abriendo Oportunidades.

\section{Aplicación para la vida:}

Cada niña escribirá en una hoja de papel un permiso vinculado a $\mathrm{AO}$, que ha querido pedir a su familia pero tiene pena y no sabe cómo hacerlo. Harán un avión de papel con su hoja y saldrán al jardín a volarlo. Cada una debe recoger un avión, tomar lo que está escrito como propio y crear una estrategia para solicitar a su familia el permiso que allí se encuentra. Podrán socializar sus soluciones para recibir insumos de sus compañeras. 


\section{Al finalizar la sesión las participantes habran...}

\section{- Diferenciado entre necesidades y deseos.}

- Tomado decisiones sobre cómo administrar sus recursos financieros priorizando sus necesidades.

- Elaborado un presupuesto.

\section{Conceptos Clave}

Necesidad: lo que no se tiene pero se necesita para vivir dignamente de forma saludable, con educación y cultura. Hay necesidades de diferentes tipos como: personales, económicas, cuando las cubrimos nos sentimos satisfechas.

Escasez: insuficiencia de recursos para satisfacer nuestras necesidades y deseos. Recurso (dinero, tiempo...) que hace falta.

Deseo: $\quad$ bienes o servicios que se ansían sin que satisfagan alguna necesidad básica.

Ingreso: dinero que se reciben a cambio de un trabajo, un bien o un servicio.

Gasto: $\quad$ dinero que se usa para comprar bienes o servicios.

Presupuesto: herramienta que ayuda a ordenar el flujo del dinero, reregistrando cada día las ingresos y los gastos.

\section{Bienvenida}

Dé la bienvenida a las participantes, confirmando quiénes están presentes o ausentes. Comparta con ellas que el día de hoy van a leer una historia sobre necesidades, deseos y planificación de gastos.

\section{Introducción del tema:}

Cuente la siguiente historia a las integrantes del grupo, pida a dos voluntarias que pasen adelante, una de ellas hará el guión de Rosi y la otra hará el de Flory.
Conceptos clave en rótulos, Marcadores, Papelógrafos con presupuestos y Hoja de trabajo "Formato del presupuesto familiar" 


\section{"La portera"}

Rosi y Flory estaban viendo el juego de futbol del equipo de Abriendo Oportunidades.

Rosi: - Dicen que portera sin suerte no es portera.

Flory: - Para ser una buena portera, lo más importante es no perder de vista la pelota.

Rosi: - Parece que sabes mucho de futbol...

Flory: - Sí, soy la mejor portera de la escuela. Pero ahora necesito tenis nuevos.

Rosi: - ¿Tenis? ¿Ya no sirven los que tienes?

Flory: - Sí, pero quiero estrenar unos en el campeonato del mes que viene...y tengo que comprar unos marcadores para una tarea de la escuela también.

Rosi: - ¿Por qué no los compras con el dinero que ganaste ayudando a tu mamá? En el Programa de AO te han enseñado a guardar una parte para comprar después lo que quieras o necesites.

Flory: - Es que... no tengo dinero: me lo gasté todo.

Rosi: - ¿Enqué?

- Flory:- No me acuerdo...

- Rosi: - ¿Cómo que no te acuerdas?

- Flory: - Es que compré unas galletas, una cartera con hilos brillantes bien bonita y después invité a unas amigas a helados... y no sé en qué me gasté lo demás.

Rosi: - Te aconsejo hacer un presupuesto para poder saber con qué dinero cuentas para planificar tus gastos.

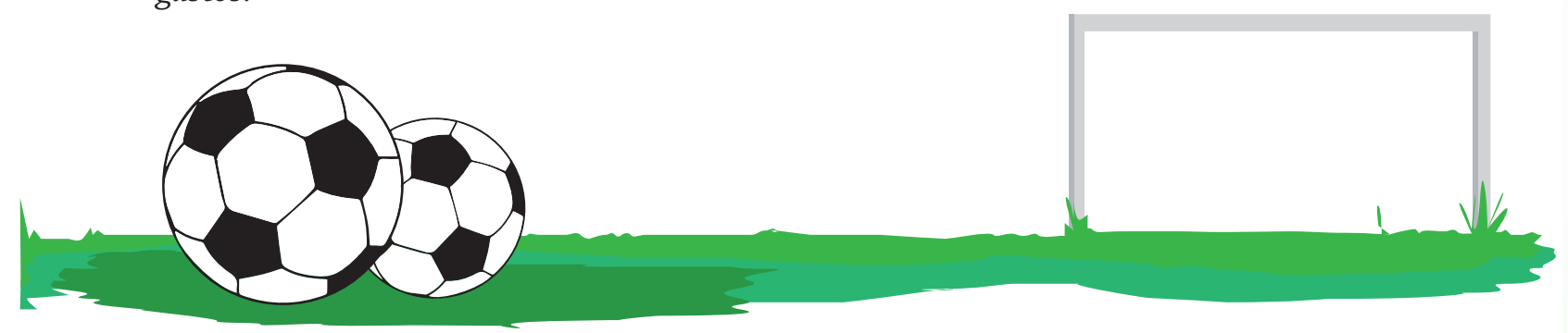

Al terminar el cuento pregunte a las participantes:

¿Por qué no puede tener Flory los tenis y los marcadores nuevos?

¿Cuáles son sus necesidades? ¿Cuáles compartes con ella?

¿Cuáles son las necesidades de tu comunidad?

¿Qué haces para conseguir lo que necesitas?

¿Te ha pasado que te quedas sin dinero y no sabes en qué te lo gastaste? 


\section{Teorizar y definir}

Forme 6 grupos y entregue a cada uno un rótulo con uno de los conceptos clave en español. Pida que el grupo lea su concepto, lo explique en su idioma materno y busque un ejemplo de eso en su comunidad. Luego cada grupo pasará a compartir con sus compañeras los ejemplos que identificaron.

Al terminar todos los grupos explique a las participantes:

Todos tenemos necesidades: de una casa (vivienda), de ropa para vestirnos (vestimenta), comida diaria (alimentación), hacer alguna actividad que nos dé placer como pasear o juntarnos con amigas a platicar (diversión). Para satisfacer esas necesidades compramos bienes y pagamos servicios: alimentos, casa, libros, transporte. Algunas veces lo que queremos no son necesidades sino que deseos, gustos por decirles de otra forma; algo que queremos pero no es importante que lo tengamos.

Los recursos que tenemos para satisfacer las necesidades y los deseos son escasos o limitados. No podemos comprar todo lo que nos gusta con el dinero que tenemos. Es necesario elegir la opción que más nos convenga. Para tomar mejores decisiones en el gasto de nuestro dinero se recomienda que hagamos un presupuesto, en él anotamos el dinero que recibimos o sea nuestros ingresos y lo que gastamos en un periodo de tiempo. Presupuestar nos permite saber con cuánto contamos y a qué destinamos cada Quetzal de nuestros ingresos. También nos permite identificar si gastamos más de lo que tenemos. En un presupuesto podemos anotar lo que queremos comprar en una semana o en un mes, para saber cuánto dinero necesitamos para cubrirlo y apartar el dinero antes de empezar a gastar.-

Pregunte a las participantes y apunte en un papelógrafo qué ingreso de dinero tienen al mes y luego en otro papelógrafo apunte lo que le digan que son sus gastos. Explique que esas dos listas son la base de un presupuesto. Presente a las participantes en un papelógrafo un ejemplo de presupuesto y explique los elementos que lo componen. Identificando los ingresos, los gastos, el saldo, las fechas etc.

Luego de haberse familiarizado a un presupuesto, presente los otros dos ejemplos. De manera que las participantes vean los tres presupuestos siguientes. Pida que se acerquen a verlos y estudiarlos bien. 


\begin{tabular}{|lr|}
\hline \multicolumn{2}{|c|}{ CASOI } \\
\hline INGRESOS \\
Ganancias del papá & $\mathbf{Q 1 , 0 0 0 . 0 0}$ \\
Ganancias de la mamá & $\mathbf{Q 1 , 0 0 0 . 0 0}$ \\
Ganancias de alguien más de la familia & $\mathbf{Q} \mathbf{5 0 0 . 0 0}$ \\
\hline TOTAL DE INGRESOS & $\mathbf{Q 2 , 5 0 0 . 0 0}$ \\
\hline GASTOS & $\mathbf{Q 6 0 0 . 0 0}$ \\
Alimentos & $\mathbf{Q 2 5 0 . 0 0}$ \\
Vivienda (renta) & $\mathbf{Q 1 8 0 . 0 0}$ \\
Servicios (luz, agua, celular) & $\mathbf{Q 7 5 . 0 0}$ \\
Salud (medicinas) & $\mathbf{Q 1 0 0 . 0 0}$ \\
Abono de algún pago & $\mathbf{Q 6 0 . 0 0}$ \\
Transporte & \\
\hline TOTAL DE GASTOS & $\mathbf{Q 1 , 2 3 5 . 0 0}$ \\
\hline Saldo (Ingresos-gastos) & \\
\hline Ingresos mayores a los gastos: Cuando los ingresos \\
son mayores que nuestros gastos, estamos en un buen \\
escenario. Tenemos una excelente oportunidad para \\
\hline ahorrar o enfrentar algún imprevisto \\
\hline
\end{tabular}

\begin{tabular}{|c|c|}
\hline \multicolumn{2}{|l|}{ INGRESOS } \\
\hline Ganancias del papá & $Q 500.00$ \\
\hline Ganancias de la mamá & $Q 500.00$ \\
\hline Ganancias de alguien más de la familia & $Q 265.00$ \\
\hline TOTAL DE INGRESOS & $Q 1,265.00$ \\
\hline \multicolumn{2}{|l|}{ GASTOS } \\
\hline Alimentos & $Q 600.00$ \\
\hline Vivienda (renta) & $Q 250.00$ \\
\hline Servicios (luz, agua, celular) & $Q 180.00$ \\
\hline Salud (medicinas) & Q75.00 \\
\hline Abono de algún pago & $Q 100.00$ \\
\hline Transporte & Q 60.00 \\
\hline \multicolumn{2}{|l|}{ TOTAL DE GASTOS } \\
\hline Saldo (Ingresos-gastos) & 0.00 \\
\hline \multicolumn{2}{|c|}{$\begin{array}{l}\text { Ingresos iguales a los gastos: Cuando los } \\
\text { ingresos son iguales que nuestros gastos, tenemos } \\
\text { finanzas equilibradas, pero cualquier imprevisto } \\
\text { puede desequilibrarlas. }\end{array}$} \\
\hline
\end{tabular}

\begin{tabular}{|lr|}
\hline \multicolumn{2}{|c|}{ CASO } \\
\hline INGRESOS \\
Ganancias del papá & $\mathbf{Q 6 0 0 . 0 0}$ \\
Ganancias de la mamá & $\mathbf{Q 5 0 0 . 0 0}$ \\
Ganancias de alguien más de la familia & $\mathbf{Q 5 0 . 0 0}$ \\
\hline TOTAL DE INGRESOS & $\mathbf{Q 1 , 1 5 0 . 0 0}$ \\
\hline GASTOS & \\
Alimentos & $\mathbf{Q 6 0 0 . 0 0}$ \\
Vivienda (renta) & $\mathbf{Q 2 5 0 . 0 0}$ \\
Servicios (luz, agua, celular) & $\mathbf{Q 1 8 0 . 0 0}$ \\
Salud (medicinas) & $\mathbf{Q 7 5 . 0 0}$ \\
Abono de algún pago & $\mathbf{Q 1 0 0 . 0 0}$ \\
Transporte & $\mathbf{Q 6 0 . 0 0}$ \\
\hline TOTAL DE GASTOS & $\mathbf{Q 1 , 2 6 5 . 0 0}$ \\
\hline \multicolumn{2}{|c|}{ Saldo (Ingresos-gastos) } \\
Ingresos menores a los gastos: Cuando los ingresos son \\
menores que nuestros gastos, estamos en problemas. \\
\hline que compramos. En un casi así, es necesario gastar menos o \\
\hline
\end{tabular}

\section{Pregunte a las participantes:}

¿Qué diferencias hay entre los tres presupuestos?

¿Qué sucede si hay un buen saldo en el presupuesto?

¿Qué sucede si no hay saldo en el presupuesto?

¿Qué sucede si los gastos son mayores que el dinero que tenemos?

¿Cuál presupuesto conviene más tener?

$$
\text { ¿Por qué? }
$$




\section{Aplicación a la vida:}

Pida a las participantes que realicen el ejercicio de presupuesto de su familia. Anime a que con la ayuda de sus papás, averigüen los ingresos semanales de la familia durante una semana. Deberán anotar en una libreta cada cosa en la que gaste su familia (por pequeña que sea la cantidad). Cuando tengan los gastos de una semana, que preparen un presupuesto de acuerdo a la hoja de trabajo "Formato de presupuesto familiar".

\section{Formato de presupuesto familiar}

\section{Ingresos:}

\section{Gastos:}

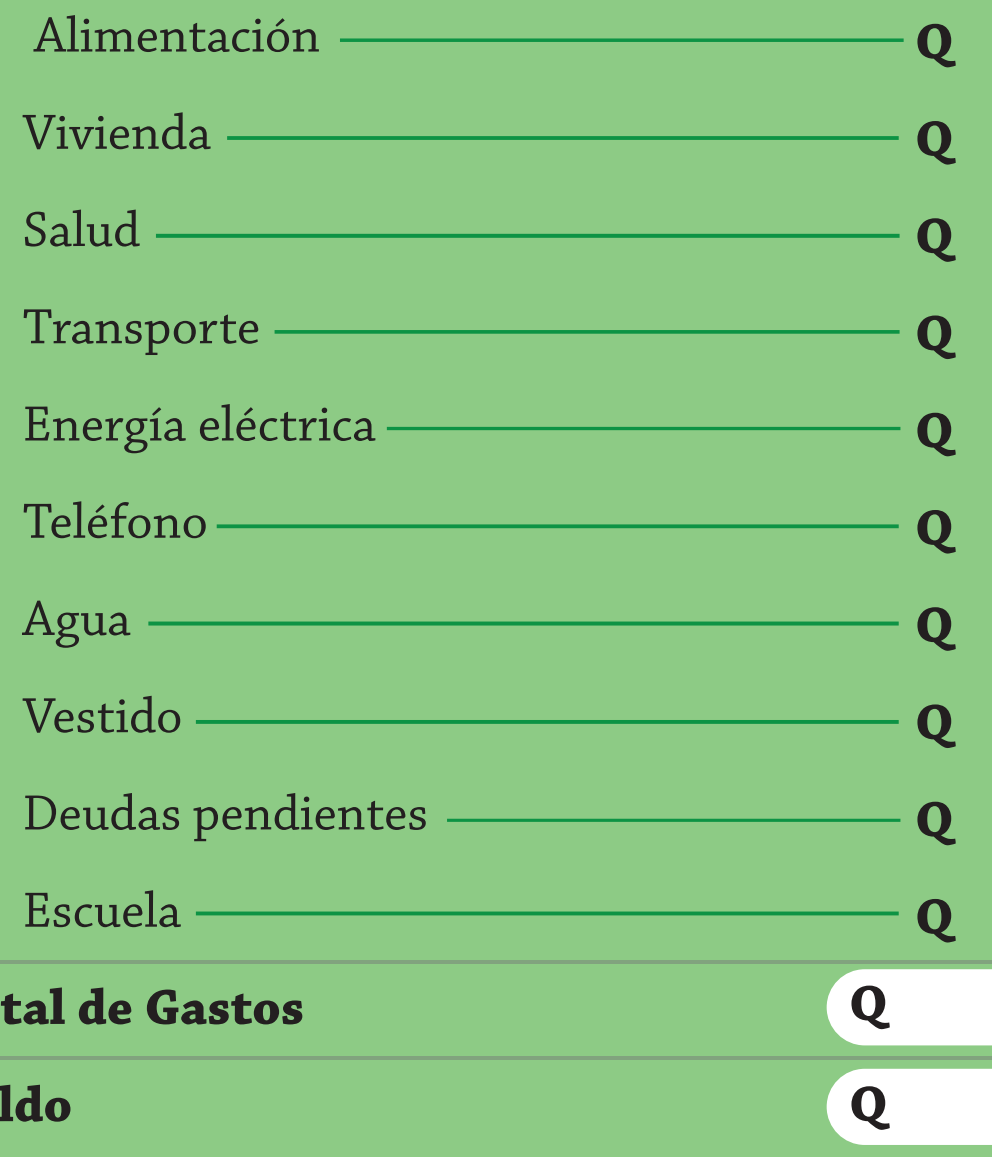

\section{Total de Gastos \\ Saldo}




\subsection{Justicia económica, poder y derechos}

\section{2 horas}

$\begin{array}{ll}\text { Al finalizar } & \text {. Conocido sus derechos laborales, económico y sociales como mecanismo para alcanzar la justicia social. } \\ \text { la sesión las } & \text {. Evalúan el respeto a sus derechos humanos en condiciones de trabajo, familia y su comunidad. } \\ \text { participantes } & \text {. Elaboran estrategias a las que pueden buscar para alcanzar el apoyo a sus derechos. } \\ \text { habran... } & \end{array}$

\section{Conceptos Clave}

Justicia social: Justicia que se encarga del desarrollo de las personas a través de acciones y/o instituciones.

Derechos laborales: condiciones mínimas de trabajo que permiten el desarrollo de las y los trabajadores así como a sus familias. Derechos económicos, sociales y culturales: Derechos humanos relacionados con los recursos económicos, el acceso a servicios sociales y la identidad para que todas las personas tengan una vida digna.

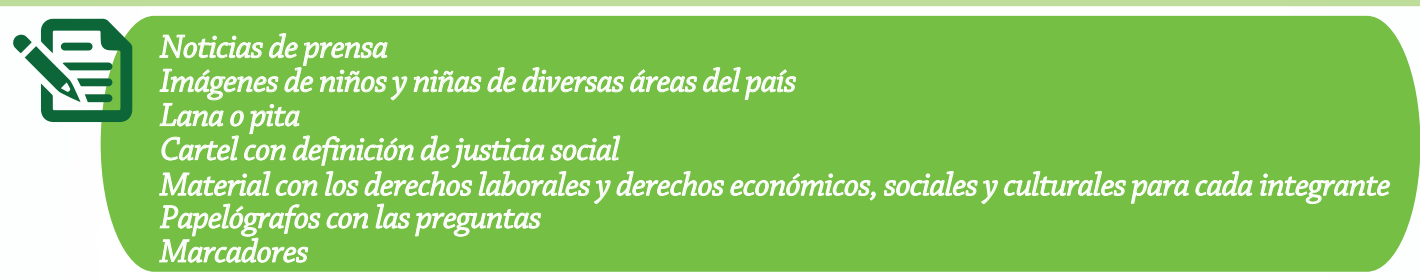

\section{Bienvenida}

Dé la bienvenida a las participantes, confirmando quiénes están presentes o ausentes. Comparta con ellas que el día de hoy van a dialogar mucho, platicar y platicar y platicar. Ojalá que tengan la lengua bien floja!!!

\section{Introducción del tema:}

Lea con las participantes alguna noticia reciente sobre un grupo de personas que esté descontenta por las condiciones de vida o por las condiciones en las que trabaja. Luego comenten sobre la noticia en plenaria. Puede hacer las siguientes preguntas guías:

¿Cuál es el descontento?

¿Qué lo está provocando?

¿Qué quisieran las personas?

¿Por qué es un problema para su vida?

\section{Teorizar y definir:}

¿Cómo afecta a sus familias?

Forme tríos y reparta a cada grupo la imagen de un niño o niña. Incluya imágenes de niños de diversas áreas del país, etnias, culturas y condiciones. Pida a cada grupo inventarse la historia del niño o niña que les tocó, deben pensar en cuánto se puede desarrollar según sus circunstancias. Le pueden poner nombre, dónde vive, qué hace, qué hacen sus papás, cuáles son sus sueños, qué oportunidades tiene, cómo va ser su futuro. 
Pida que todas regresen a plenaria y abra el espacio para que compartan las historias de su niño o niña. Coloque una pita en la pared y dígales que la pita representa el desarrollo de los niños y niñas. Deben colocar las imágenes en orden según cuánto se pudo desarrollar cada uno en su vida. Para esto deben dialogar y ponerse de acuerdo entre ellas. Al terminar pregunte:

\author{
¿Por qué unos se desarrollaron más que otros? \\ ¿Cómo afecta las condiciones de vida de su familia en su desarrollo? \\ ¿Quiénes han tenido más oportunidades? \\ ¿Hay diferencias entre las oportunidades entre los niños y niñas? \\ ¿Por qué las niñas y jóvenes dejan de estudiar antes que los niños y hombres? \\ ¿Esto cómo afecta sus oportunidades y su desarrollo? \\ ¿Qué condiciones debiéramos tener todos y todas para desarrollarnos al máximo?
}

Presente en un cartel la definición de Justicia Social permita que lo lean varias veces, una vez individualmente, otra vez que una compañera lo lea, la siguiente todas lo pueden leer juntas, luego identifican palabras centrales de la definición. Invite a que relacionen el concepto justicia social con el desarrollo de los niños y las niñas según sus condiciones de vida.

Introduzca la temática de derechos laborales, económicos, sociales y culturales preguntando:

¿Qué son los derechos humanos?

¿Cuáles recuerdan?

¿Cuáles se cumplen o no en las historias de los niños?

¿Qué condiciones debieran ser derechos para todas las poblaciones?

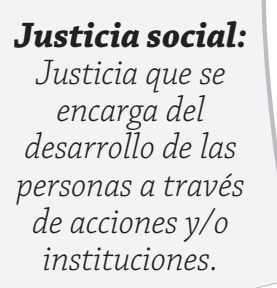

Entregue a cada participante material con información acerca de los derechos laborales, económicos, sociales y culturales. Lea el material con ellas y vaya explicando la información que allí le presenta. Use ejemplos e invite a que ellas piensen en ejemplos desde su propia experiencia. Al finalizar la lectura pregunte:

¿Qué relación hay entre los derechos humanos y la justicia social?

¿Qué instituciones del estado debieran garantizar a las personas sus derechos laborales, económicos, sociales y culturales?

¿Cómo cambiaría la vida de algunos niños y niñas si tuvieran garantizados sus derechos? 


\section{Aplicación a la vida:}

Forme tres o cuatro grupos. A cada uno entregue un papelógrafo con las preguntas de uno de los cuatro incisos para que las contesten.

1. ¿Qué trabajo es más frecuente entre las mujeres de esta comunidad? ¿En qué condiciones se da el trabajo? Qué pago reciben?¿Qué permisos tienen?¿Cómo lo resuelven con sus hijos y maridos?

2. ¿Cuántos años estudian las jóvenes de la comunidad? ¿Por qué dejan de estudiar?¿Qué dificultades tienen las familias para que sigan estudiando? ¿Qué apoyo reciben del gobierno para que sigan estudiando las niñas y las jóvenes?

3. ¿A nombre de quién están los terrenos en la comunidad? ¿Es común que un terreno esté a nombre de una mujer? ¿Cómo se decide a nombre de quién se pone el terreno?

4. ¿Cómo son las relaciones entre hombres y mujeres en la comunidad? ¿Qué permisos tienen los hombres sobre las mujeres? ¿Cuáles son las diferencias entre la crianza de niños y niñas?

Al terminar pida que intercambien papelógrafos con los otros grupos. Lo leen e identifican:

$$
\text { -Los derechos que están siendo violados }
$$

-Las instituciones que debieran estar garantizando el derecho pero no lo están haciendo

-Una acción que las mujeres pueden realizar para cuidar su derecho.

Comparten sus respuestas con la plenaria al terminar.

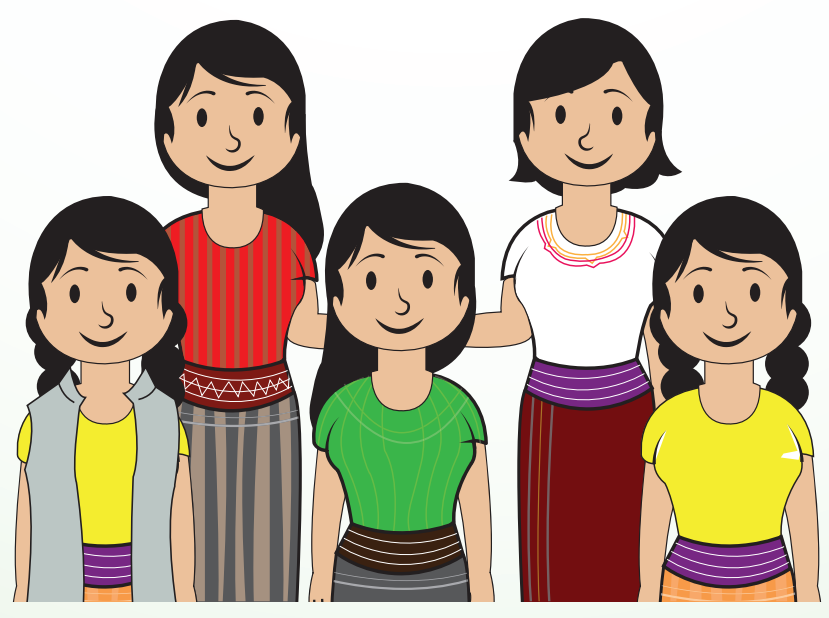




\section{RECURSO DE APOYO PARA LA MENTORA}

\section{Resumen del Convenio de Derechos Éconómicos, Sociales y Culturales}

Los derechos económicos, sociales y culturales DESC constituyen una amplia categoría de derechos humanos. Casi todos los países del mundo garantizan dichos derechos. Entre éstos se encuentran:

Derecho al trabajo, a condiciones laborales justas y equitativas, a la protección contra el trabajo forzado y obligatorio y a crear sindicatos y formar parte de ellos. Por ejemplo cuando para un mismo trabajo los salarios de las mujeres son menores a los salarios de los hombres, no se está cumpliendo el derecho de las mujeres al trabajo pues no es una condición de trabajo justa.

Derecho a la educación, garantizando, por ejemplo, el derecho a una educación primaria gratuita y obligatoria y a una educación suficientemente disponible, accesible, aceptable y adaptable a cada persona concreta. Por ejemplo si en tu comunidad no hay una escuela o el maestro nunca llega, se te está negando el derecho a la educación.

Derechos culturales de las minorías y de los pueblos indígenas Por ejemplo si te fuera prohibido usar tu vestimenta o hablar tu idioma, se te está negando tu derecho cultural.

Derecho al disfrute del más alto nivel posible de salud física y mental incluidas unas condiciones de vida saludables y la disponibilidad de servicios de salud accesibles, aceptables y de buena calidad. Por ejemplo cuando en el centro de salud no hay medicinas disponibles, tú no tienes derecho a salud física.

Derecho a una vivienda adecuada, que incluye la seguridad de tenencia, la protección contra desalojos forzosos y el acceso a una vivienda asequible, habitable, bien situada y culturalmente satisfactoria. Por ejemplo si te sacaran de tu casa porque dicen que no te pertenece el terreno, se te está negando el derecho a una vivienda adecuada.

Derecho a la alimentación, que incluye el derecho a no pasar hambre y el acceso permanente a comida nutritiva suficiente o a los medios para obtenerla. Por ejemplo si el precio del maíz subiera y no pudieras comprarlo porque está demasiado caro, se te está negando el derecho a la alimentación.

Derecho al agua, es decir, el derecho a disponer de agua suficiente y a contar con instalaciones higiénicas seguras y accesibles física y económicamente. Por ejemplo cuando debes caminar muchísimo al río para ir a traer agua porque no tienes chorros en casa, se te está negando el derecho al agua. 


\section{La importancia de ahorrar}
Al finalizar
la sesión las
Comprendido qué es el ahorro y formas de ahorrar.
participantes
habran...
Vinculado el ahorro como estrategia para alcanzar metas y atender emergencias.
- Ideado estrategias para iniciarse o fortalecer su hábito de ahorrar.
- Identificado diferentes opciones de ahorro desde diferentes instituciones financieras.

\section{Conceptos Clave}

Ahorro: El hábito de apartar una porción de lo que se recibe o lo que se tiene sin gastarlo. Lo que se junta de ahorros permite hacer inversiones más grandes para cumplir las metas o bien atender emergencias que puedan presentarse.

Opciones de ahorro: Existen muchas alternativas para apartar los recursos y en dónde guardarlos. Hay bancos, instituciones microfinancieras, cooperativas, nuestros hogares, cuchubales, grupos de ahorro comunitarios y otros tipos de instituciones. Vale la pena investigar en nuestra comunidad los que están disponibles para nosotros.

Cada una de las opciones de ahorro tiene ventajas y desventajas. Depende de nosotros decidir qué tipo de servicio necesitamos y cuál es la opción de ahorro que mejor se adapta a nuestras necesidades.

\section{Bienvenida}

Dé la bienvenida a las participantes, confirmando quiénes están presentes o ausentes. Pídales que compartan sus sueños...si tuvieran Q10,000.00 suyos, solo suyos

\section{¿Cómo los usarían?}

¿En qué los invertirían?

¿Cuánto tiempo se tardarían en juntar esa cantidad?

¿Alguna tiene ahorros? ¿Cómo lo hace?

\section{Introducción del tema:}

Coloque a las participantes en círculo para contarles una historia, puede colocar el título en un papelógrafo y pedirles que infieran de qué se tratará. Luego de sus ideas lea la historia.

\section{"Una visita al mago del ahorro"}

(tomado y adaptado de www.valores.com.mx / Cuento de Verónica Huacuja)

Ana es una joven que recibe de su mamá Q 1.00 para gastarlo en su escuela. De ese dinero, ella ahorra la mitad todos los días, lo guarda en su alcancía, por lo que al final del año ¡tiene Q 90.00! Pero, para Ana, tener tanto dinero es un problema que resolver, pues se pregunta qué hacer con él. Quiere comprarse tantas cosas y al mismo tiempo no gastárselo todo. Desea comprar los dulces que tanto le gustan, la bolsa de lentejuelas que venden en la tienda de la esquina y visitar a su abuela a quien ve tan poco por vivir tan lejos.

Esta situación llegó a oídos del Mago del Ahorro quien, sin más, tomó su varita mágica y voló a visitar a la joven. Al llegar le dijo: 
—Hola Anita, vengo a aconsejarte que planees bien cómo gastar tu dinero, pero también cómo seguir ahorrándolo.

— ¡Tú sí me comprendes, Mago! — exclamó la joven, entusiasmada.

- Sé exactamente a lo que te refieres — respondió divertido. —Quieres saber cómo emplear tu dinero sin gastarlo todo, es decir, planear bien qué hacer con tus ahorros.

Entonces, dio un giro a su varita, hizo aparecer un lápiz y una libreta y escribió:

- iEsta es la fórmula mágica! Puedes ahorrar de tres formas: a corto, mediano y largo plazo. A corto plazo significa ahorrar en periodos breves, como un par de días, para adquirir algo barato, como los dulces que tanto te gustan. A mediano plazo es ahorrar en periodos más o menos largos, como unas semanas, para comprar algo un poco más caro, como la bolsa de lentejuelas que quieres. En cambio, ahorrar a largo plazo es hacerlo en periodos más amplios, como en varios meses, para algo que resulte caro, como un viaje a la lejana casa de tu abuela para las vacaciones de fin de año.

—ZZas! ¿Eso significa que puedo ahorrar, gastar y seguir ahorrando?

—Así es —sonrió el Mago-. Puedes hacerlo de esa forma.

Entonces, la joven sacó un calendario de su cajón, tomó el lápiz y la libreta que le dio el Mago y comenzó a planear su ahorro y sus compras en el tiempo. Hizo cálculos y vio que el dinero que había ahorrado le podía servir para todo lo que quería y, aún así, seguir ahorrando para otras metas. Utilizaría una alcancía para cada tipo de ahorro: una de color amarillo, para el corto plazo, una naranja, para el mediano, y otra de color azul para el largo plazo. iQué buena idea!

Ana, desde que siguió el consejo del Mago del Ahorro, es una joven afortunada pues ya conoce cómo ahorrar, planear y utilizar su ahorro y hasta tener un presupuesto.

\section{Luego de leer la historia pregunte al grupo:}

¿Cuál fue el consejo que le dio el mago a Ana para ayudarla a utilizar correctamente su dinero?

¿Fue un buen o un mal consejo? ¿Por qué?

¿Cómo piensas que se relaciona el valor de la responsabilidad con el hábito del ahorro?

¿Qué dificultades hay para ahorrar?

¿Qué facilidades tienen ustedes para ahorrar?

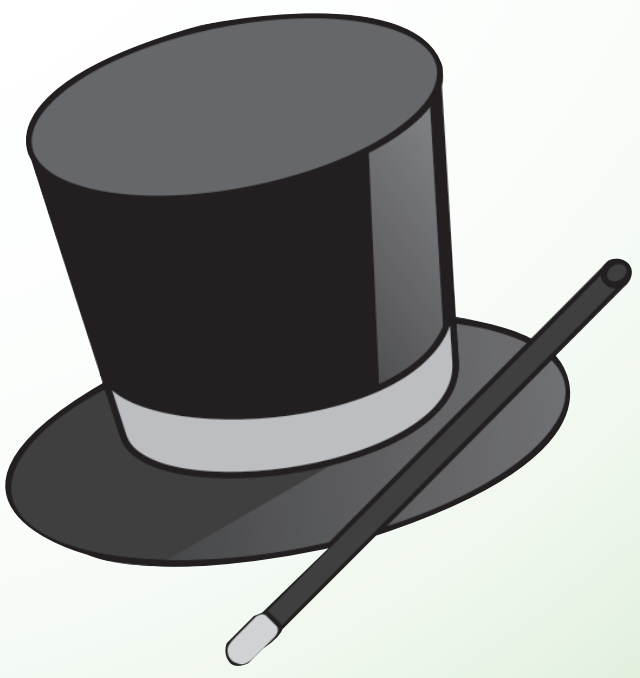




\section{Teorizar y definir:}

Presente en un papelógrafo la palabra ahorro y las opciones sobre los lugares en los que pueden ahorrar. Lea con ellas la información y discutan:

¿Qué opciones hay en la comunidad y el municipio para ahorrar?

\section{Bancos, cooperativas, cuchubales, en casa}

¿Qué les gustaría hacer con el dinero que logren ahorrar?

¿Cuánto creen que pueden ahorrar en un mes?

¿Cómo y dónde guardan sus ahorros?

¿Para qué ahorrar? ¿Por qué ahorrar?

\section{Para cubrir los gastos de emergencias que pueden surgir, para invertir nuestro dinero en algo que nos puede beneficiar más a mediano y largo plazo, para poder tomar decisiones sin que la falta de dinero sea impedimento para lo que queremos hacer.}

\section{Pida que le den palabras en su idioma materno con las que se puede definir Ahorro}

y escríbalas en un papelógrafo.

\section{Aplicación a la vida:}

\section{Diga a las participantes:}

Los retos y las dificultades ponen a prueba nuestra capacidad de tomar decisiones y de cuidar nuestros ahorros. Eventos inesperados, por ejemplo, una enfermedad, la muerte de un familiar o la pérdida del empleo, nos colocan en una situación crítica y necesitamos reaccionar rápidamente. Si no hemos planeado esos eventos, echamos mano de lo que se puede para hacer frente estas situaciones $y$, a veces, la presión del momento nos hace tomar malas decisiones. Cuando tenemos ahorros podemos anticipar lo que queremos hacer. Para ahorrar hay que reducir los gastos o aumentar los ingresos.

Vamos a suponer que cada una ha sido capaz de ahorrar algo de dinero y que ha hecho sacrificios para guardar un poco cada mes, pero que ha valido la pena porque ya tiene pensado en qué lo va a invertir y espera que poco tiempo después tenga más dinero disponible. Algo pasa en su vida, su familia, sus amigos que presenta la necesidad de tener dinero fácil y rápido para resolver el problema. ¿Qué harían? Lo van a discutir en grupos.

Forme dos grupos, entregue a cada grupo una tarjeta con una de las historias de abajo. Cada grupo debe leer la tarjeta y discutir la situación de la joven, sus alternativas, cómo afectaría dar sus ahorros, cómo afectaría no dar los ahorros. 
Luego de discutir, el grupo debe decidir qué va a hacer, dar o no los ahorros y de qué manera, escribiendo un final para la historia. Cada grupo debe presentar al otro la historia y lo que decidió hacer, pueden usar sociodramas, cuento, dibujo, canción, historieta...

Entregue una hoja de trabajo a las jóvenes para que organizadas en grupos visiten la cooperativa de ahorro, banco más cercano u otras opciones de ahorro. Permita tiempo en la próxima sesión para que compartan sus respuestas.

\section{Historia 1: EL NOVIO}

Marta tiene 19 años y para estudiar en el Instituto fue al pueblo donde vive con sus familiares.Ellos le han dado un lugar en su casa, pero no dinero para gastar. Entre semana trabaja haciendo bordados y con lo que gana paga todos sus gastos. Hasta ahora ha logrado ahorrar Q 300. Ella es muy disciplinada con el ahorro, porque sabe que no quiere vivir con su familia para siempre y tal vez después de terminar el bachillerato puede poner un salón de belleza.

Su novio, Samuel es un gran soñador y quiere juntarse con un su primo que está en Chicago, Estados Unidos, para trabajar allá, hacer dinero y venirse a casar con Marta. El piensa que con lo que ha ahorrado Marta y lo que él tiene le alcanzaría para irse un año. Él está seguro que pueden hacer el dinero

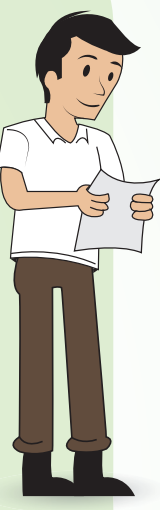
suficiente para que los dos puedan cambiarse juntos a un lugar propio.

Ella empezó a considerar hacerle caso y entregarle a él los Q300.00 para que pueda llegar al norte a trabajar, mientras ella lo espera en su pueblo. ¿Qué le recomiendan a Marta?

\section{Historia 2: LOS PADRES}

Olga tiene 16 años y vive con sus padres, su hermano menor y su hermana. Ella gana un poco de dinero, ayudando a su tía en el puesto del mercado los sábados. Su sueño es asistir a un curso de computación y ha calculado que necesita ahorrar sus ingresos durante 1 año para tener suficiente dinero para la inscripción en el curso y los materiales.

A su papá le gusta jugar cartas; cuando él gana, le gusta presumir de su éxito dándole a los niños un poco de dinero extra para el almuerzo. Cuando el pierde, ellos no pueden cubrir todos sus gastos. La mamá de María quiere preparar una comida especial de cumpleaños para el hermano menor de María, a quien le encanta la carne. Pero la madre de María está corta de efectivo y sabe que María tiene sus ahorros en la casa. Ella ordena a María que le de Q100, que es casi la mitad de sus ahorros.

Los dos padres de María creen que las finanzas deben ser controladas por los adultos, quienes están en mejor posición para equilibrar las necesidades de todos en la familia. ¿Qué hará María? 


\section{Consulta sobre opciones de ahorro}

Visita las instituciones, personas y/o bancos que tienes cerca de ti en dónde puedes tener ahorros y pregunta:

1. ¿Cuánto dinero se necesita para iniciar el ahorro?

2. ¿Cuáles son los requisitos para abrirla?

3. ¿Qué beneficios se obtienen con la cuenta?

4. ¿Cuánto se paga por tener el ahorro allí?

Escribe la información de cada opción en la siguiente tabla:

\begin{tabular}{l} 
OPCIÓN $\begin{array}{l}\text { ¿Cuánto dinero } \\
\text { se necesita para } \\
\text { iniciar el ahorro? }\end{array}$ \\
$\begin{array}{l}\text { ¿Cuáles son los } \\
\text { 1. }\end{array}$ \\
\hline 2Qué beneficios? \\
\hline se obtienen?
\end{tabular}




\subsection{Haciendo mi vida: opciones de trabajo}
Al finalizar
Reflexionado sobre los propósitos de trabajar.
la sesión las
Identificado escenarios de violencia entre las opciones del mercado laboral y el espacio doméstico
participantes
habran...
Enumerado las opciones de trabajo que existen en su comunidad
Cómo administrar el dinero que recibirían por trabajar

\section{Conceptos Clave}

Trabajo: el esfuerzo que se realiza para producir un bien o recibir un pago que permita satisfacer las necesidades $y$ deseos.

Salario: pago monetario que se entrega a una trabajadora por el trabajo que ha realizado.

Violencia: infringir daño físico, emocional, psicológico a una persona. Limitar las oportunidades de desarrollo o las posibilidades de satisfacer sus necesidades básicas son también formas de violencia.

Papelografos. Hojas en blanco · Lápices y boligrafos

\section{Bienvenida}

Dé la bienvenida a las participantes, confirmando quiénes están presentes o ausentes. Comparta con ellas que el día de hoy van a pensar en su futuro y las oportunidades de trabajo que se les presentan.

\section{Introducción del tema:}

Pida a las participantes que definan qué es el trabajo y que compartan qué trabajos realizan, y las opciones de trabajo que tendrán en su comunidad. Algunos detalles que pueden contar son: las condiciones de trabajo (horario, lugar, para quién, qué hacen, prestaciones) y qué les gusta y disgusta de su trabajo. Apunte sus respuestas en un papelógrafo como lluvia de ideas.

\section{Teorizar y definir:}

Juegue la ronda preguntona para que reflexionan entre sí sobre la importancia y el propósito del trabajo. Para ello deben formar dos ruedas, colocándose una dentro de la otra viendo de frente a sus compañeras pida que caminen en dirección contraria y cuando diga alto se detienen para escuchar la pregunta y comentarla con la compañera que les haya tocado. Haga una de las siguientes preguntas en cada ronda: 


\section{1. ¿Cómo se encuentra trabajo en esta comunidad?}

2. ¿Qué trabajos hay? ¿Qué beneficios dejan las opciones?

3. ¿Por qué se trabaja tanto en esta comunidad?

4. ¿Para qué se trabaja tanto en esta comunidad?

5. ¿Qué trabajos hacemos las mujeres en esta comunidad por los que sí se les paga?

6. ¿Qué trabajos hacemos las mujeres en esta comunidad por los que no se nos paga?

7. ¿Qué riesgos de violencia se dan en los trabajos?

El tipo de trabajo que seleccionamos es una decisión muy personal. El trabajo nos ayuda a "ganarnos la vida" que es lo que nos ayuda a "hacer la vida". Debemos tomar en cuenta nuestros valores personales y talentos para asegurarnos que estaremos felices en el trabajo que hagamos.

Pida que se dividan en tres grupos y que expliquen la diferencia que entienden entre hacer la vida y ganarse la vida.

\section{Aplicación a la vida:}

Pida que se reúnan en parejas para trabajar la hoja de trabajo "Mis opciones de trabajo". Al terminar de llenarla todas deben compartir su análisis de una de las opciones de trabajo al resto del grupo.

\begin{tabular}{lll} 
Trabajo & $\begin{array}{c}\text { Me ofrece } \\
\text { Exige que }\end{array}$ & $\begin{array}{c}\text { Rieso de } \\
\text { violencia }\end{array}$ \\
\hline
\end{tabular}




\subsection{Yo me expreso asertivamente}

\section{Al finalizar \\ la sesión las \\ participantes \\ habran...}

- Practicado expresarse asertivamente.

Formulado respuestas asertivas ante situaciones cotidianas que afectan sus derechos humanos.

Discutido las posibles consecuencias y reacciones de usar la comunicación asertiva con diferentes personas de su comunidad.

\section{Conceptos Clave}

Asertividad: la habilidad para decir de forma clara y directa lo que uno desea y quiere.

Comunicarse de esta manera beneficia la seguridad personal y la autonomía.

\section{2 horas}

Comunicarse de esta manera beneficia la seguridad personal y la autonomía.
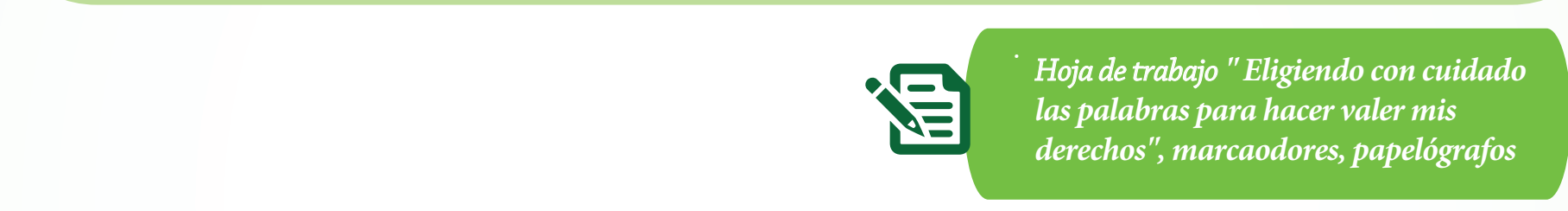

\section{Bienvenida}

Dé la bienvenida a las participantes, confirmando quiénes están presentes o ausentes. Comparta con ellas que el día de hoy van a conocer sobre formas de comunicarse y lo buena que es la asertividad para demostrar a los demás que estamos seguras de lo que decimos y queremos.

\section{Introducción del tema:}

Comparta con las participantes la historia de la lideresa como si fuera un cuento.

Cuando quiere decir algo, la lideresa se pone nerviosa aunque sabe que tiene que mirar a los ojos y a la cara de las personas cuando habla y que tiene que tener un tono de voz tranquilo. Ella también sabe que tiene que decir las cosas que son importantes para ella. Pero las otras personas no le prestan atención aunque ella es una lideresa.

La lideresa sabe qué hacer para ser asertiva pero cuando habla con sus papás para pedir permiso y salir de la casa no lo dice claramente y se mete en peleas. 
Dibuje lo siguiente grande y muéstrelo a las participantes, divida a las participantes en dos grupos, uno lee el guión de la lideresa y el otro grupo el de respuesta.

\section{Salir de la casa es algo}

importante para mi Uds.

Nunca me dejan salir.
Hija siempre sales. Vas al campo para trabajar, vas

al mercado con tu mamá.

Vamos a ver qué le pasa cuando habla con su mejor amiga, se siente sola porque quiere que la amiga le llame más

Tú nunca me llamas
¿Nunca te llamo? ¿Cómo
que nunca te llamo?
Estamos hablando ahora

por teléfono.
No te importo.

¿Qué dijiste? Estaba mirando fútbol y no escuché nada.
Vamos a ver qué le pasa a cuando habla con su novio, ella se siente triste porque él no la escucha cuando habla.
Vamos a ver qué le pasa a la lideresa cuando habla con su tía que le está gritando.
¡Ya no me grites más!

Yo soy tu tía y puedo

gritar si quiero. 


\section{Pregunte a las participantes:}

¿Qué tipo de comunicación usó la lideresa?

¿Cómo hacía sentir a las otras personas cuando les hablaba?

¿En cuántos casos logró resolver sus problemas?

¿En las conversaciones cómo dijo la lideresa lo que esperaba de la otra persona? ¿Cómo le

recomendarían a ella que hable sus sentimientos en cada caso?

¿Hay algunas cosas que ella podría mejorar en la manera que habla o se comunica?

\section{Teorizar y definir:}

Invite a las participantes a pensar otras formas de comunicar lo que la lideresa quiere decir y cambie lo que dice en cada globo de diálogo.

Diga a las participantes:

Cuando hablamos y nos comunicamos no tenemos que siempre decir TÚ y TÚ y TÚ. Tenemos que decir lo que a nosotros nos gustaría que la otra persona haga.

Por ejemplo. A la tía la le puede decir "Tía, me gustaría que me hables con más calma por favor." De esta manera la tía entiende exactamente lo que la lideresa quiere de ella y no siente que la lideresa está tratando de mandarla.

\section{Cambiemos cada una de las frases usadas por la lideresa.}

\section{Aplicación para la vida:}

Entregue la hoja de trabajo "Eligiendo con cuidado las palabras para hacer valer mi derecho". Van a trabajar en grupos de tres para definir cómo contestar de forma asertiva a las situaciones que les plantea la hoja de trabajo. Luego de un tiempo pida que compartan con el grupo sus respuestas. 
Al finalizar

la sesión las

participantes

habran...
Identificado situaciones peligrosas de diversa naturaleza.

Creado estrategias para evitar prevenir los riesgos que enfrentan.

Las participantes reconocen que las decisiones tomadas sin reflexionar llevan a más peligros.

\section{Conceptos Clave}

Toma de decisiones: las mujeres tenemos la capacidad de analizar lo que está pasando y pensar bien qué queremos para el bien nuestro y de la comunidad. De acuerdo a eso, vemos nuestras opciones y escogemos la que tendrá mejores resultados a corto y largo plazo.

Alternativa: la opción entre dos o más posibles acciones y decisiones.

Hoja de trabajo "Tomo decisiones para salir de situaciones peligrosas"

Historias, Papelógrafo con preguntas y Cartel con los 7 pasos para

tomar decisiones

\section{Bienvenida}

Dé la bienvenida a las participantes, confirmando quiénes están presentes o ausentes. Comparta con ellas que el día de hoy van a leer varias historias para ayudar a las protagonistas a identificar los riesgos y tomar las mejores decisiones posibles. Identificar riesgos y tomar decisiones para prevenirlos es algo que pueden poner en práctica todos los días.

\section{Introducción del tema:}

Forme 5 grupos entre las participantes y entregue una de las historias a cada grupo. Pida que lean la historia y en el grupo discutan las siguientes preguntas que usted lleva escritas en un papelógrafo.

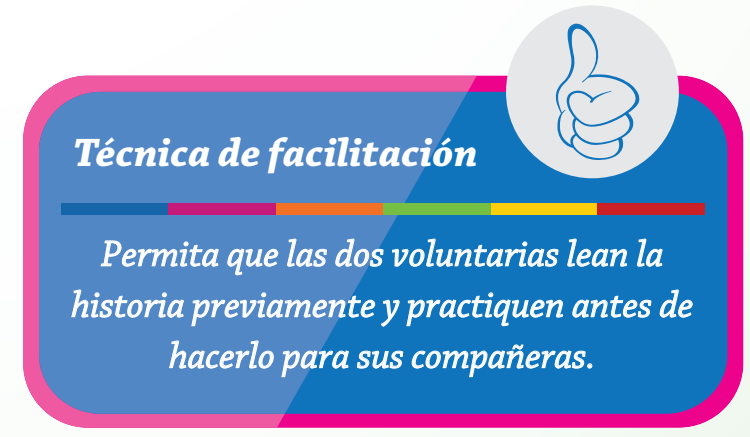

\section{Preguntas para el papelógrafo:}

¿Qué peligros está afrontando en su vida? (familia, amigos, trabajo)

¿Qué trabajo está desarrollando?

¿Qué derechos le están siendo violados o están en peligro? 
Al terminar el trabajo en sus grupos, pida que una representante de cada grupo pase a compartir la historia y las respuestas a las preguntas. Al terminar las exposiciones promueva el diálogo en la plenaria.

Algunas preguntas que pueden ayudar para abrir las experiencias son:

¿Conocen a gente que han trabajado en situaciones como esas?

¿Por qué aceptan estar en situaciones peligrosas?

¿Qué riesgos corren las personas que permanecen en situaciones peligrosos?

¿Por qué algunas mujeres se mantienen en relaciones riesgosas para su bienestar y el de sus hijos?

¿Si un marido es violento, debe la mujer quedarse en casa por la unidad de la familia? ¿Estarán bien los hijos e hijas viviendo en una ambiente de violencia?

¿Cómo pueden tomar decisiones para mejorar y no hacer más peligrosa su situación?

Vaya anotando las respuestas en un papelógrafo que dice ALERTA A... y colóquelo en

un lugar visible para tomar conciencia de las situaciones que son riesgosas para ellas en su comunidad.

\section{Teorizar y definir:}

Dialogue con las participantes sobre las siguientes ideas:

Muchas personas tienen trabajos peligrosos o se mantienen en situaciones de riesgo porque piensan que es su única opción. Sin embargo, al mantenerse allí dificultan más su situación. Ante los problemas que enfrentamos es importante pensar en qué alternativas tenemos, que personas e instituciones nos pueden apoyar.

¿Por qué saber tomar decisiones es una herramienta importante para prevenir los peligros que afrontamos en nuestra comunidad y fuera de ella?

Lleve un cartel con los 7 pasos para tomar buenas decisiones y lea la información con las participantes. Lea con las participantes la historia 1, el caso de Griselda, y pongan en práctica los siete pasos.

\section{Aplicación a la vida:}

Forma grupos de tres participantes que sean amigas. Entrega la hoja de trabajo "Tomo decisiones para salir de situaciones peligrosas". Invite a las participantes que escojan una historia, consideren que van a afrontar y que es peligrosa para ellas. Una vez la tienen deben ir realizando cada uno de los siete pasos para llegar a una decisión que les protege.

Al finalizar pida a tres grupos que compartan los resultados de su ejercicio.

\section{Siete pasos para tomar una buena decisión}

1.Identifica cuáles son las metas a lograr y los valores que quieres respetar.

2.Haz una lista de todas las posibles alternativas que se tienen.

3.Para cada alternativa identifica los riesgos y las ventajas que te ofrece.

Compara ésta con tus metas y valores para desechar las que sean contrarias.

4.Busca más información acerca de las alternativas que mejor te parecen.

5.Consulta tus ideas y sentimientos con otra persona que tenga experiencia en el tema

y te pueda dar un buen consejo.

6.Revisa nuevamente tus alternativas con la nueva información y el consejo que has recibido.

7.Enumera los pasos a seguir para la alternativa que has escogido, cuida que estos pasos te permitan alcanzar tu meta y que respeten los valores que te propusiste en el inicio. Comparte tu decisión con quien te aconsejó y las personas que son cercanas a ti y te quieren. 


\section{Historia 1}

Para Griselda su casa es una pesadilla y el trabajo es todavía peor. Ella lleva 9 años de trabajar en la cosecha de fresas, empezó cuando tenía seis y su mamá la llevaba a trabajar. Recuerda ver de lejos a otros niños que iban a la escuela pero ella no podía ir. Muchas veces trató de decirle a su mamá que la llevara a la escuela pero doña Josefa siempre fue nerviosa y enojada, nunca quiso dejar sola a Griselda. Ahora que Gris tiene 15 años entiende a su mamá, vive con un hombre que le grita todo el tiempo y le exige que le haga la comida y cuanto favor él quiera. Hoy el hombre la está obligando a casarse, ella no quiere, pero por estar grande no la contratan en la cosecha de fresas y como nunca fue a estudiar...no tiene trabajo para aportar a su familia. Un día Griselda estaba enojada con su novio que salió con otra muchacha y cuando vio a su papá llegar a casa y pedir comida gritando, ella se animó y le dijo que no había comida en la casa para un borracho. Su papá se puso furioso y con la mano abierta le pegó a Griselda. Ese instante la hizo decidir salirse de su casa y ahora está viviendo en la calle.

\section{Historia 2}

Zoila llega muy cansada a su casa. Después de 12 horas de trabajo sus manos le duelen tanto de haber horneado todo el día que apenas puede encontrar la fuerza para abrir la puerta. Ha ahorrado algo de dinero y sabe que podría dejar la panadería para trabajar vendiendo artesanía con su hermana, pero la dueña le dice que tiene que seguir trabajando para pagar la deuda de su familia. Ese fue el momento cuando Zoila empezó a trabajar, su papá la llevó para que trabajara para pagar su deuda. Ya ni puede recordar la deuda, y ni siquiera sabe cuánto debe su familia. Le pide a su jefa que hagan las cuentas juntas pues ella piensa que con el año que lleva de estar trabajando y recibiendo la mitad del sueldo ya ha terminado de pagar lo que debe. No sólo su sueldo es poquito sino que además está recibiendo la mitad. Decide Zoila mejor dormirse, al fin de cuentas mañana va a tener que ir a trabajar y ni siquiera le darán permiso de ir al Centro de Salud para verse las manos.

\section{Historia 3}

Ángela solo tiene 17 años pero su mamá está enferma y necesita medicina. Por eso ella ha decidido ir a la ciudad para encontrar trabajo limpiando casas. Con suerte rápidamente encontró un trabajo, duerme y le permiten comer algo en la casa. A fin de mes podrá mandar la mayor parte de lo que gana a su mamá. Hay una cosa que le molesta, está un poco preocupada porque el hijo de la dueña de la casa siempre la toca. Una vez Ángela se atrevió a decirle a la dueña lo que estaba pasando, el hijo negó todo a su mamá. Ángela ha decidido seguir en la casa con tal de ayudar a su mamá, pero tiene miedo. El día siguiente el hijo violó a Ángela y le dijo que ella es una mujer sucia. 


\section{Historia 4}

Perla trabaja en una finca en Alta Verapaz en donde cosecha cardamomo. Ella está embarazada y la panza se le empieza a notar, pero la esconde porque tiene miedo que si se dan cuenta no la vuelvan a buscar para el trabajo en la finca. Esta mañana Perla se siente un poco mal, piensa que algo en su panza no está bien pero igual sigue trabajando en el campo. Una su compañera la vio perder el equilibrio y pálida.la ayudó a sentarse. Para ella fue un alivio, una mano amiga y un momento de descanso, tomó agua y descansó en la sombra. A lo lejos se escuchó el motor de un pickup...jEs el carro de la finca! ¡Viene allí el Patrón! Oyó Perla a los demás trabajadores exclamar. Sintió que se le iba el alma al suelo y no sabe de dónde buscó las fuerzas para levantarse y hacer como que estaba bien para seguir trabajando con tal de que el patrón no la viera.

\section{Historia 5}

Las hermanas Catam viven en San Marcos. La mayor tiene 15 y la menor tiene 6 con dos en medio una de 10 y otra de 8. Su familia les permite ir a estudiar entre semana pero el fin de semana van a leñar al bosque. Es un trabajo pesado, caluroso, cansado para los brazos y la espalda al momento de recoger y acarrear la leña de un lugar a otro. Elbia, la hermana mayor lleva tantos años que ya empezó a ver que su espalda se dobla muy frecuentemente, le preocupan sus hermanitas y busca enseñarles la mejor forma de cargar la leña. Frecuentemente se encuentran en el bosque hasta tarde y ella se tiene que hacer cargo de las tres hermanas, es cierto que llevan leña y machetes para defenderse pero entre animales del bosque, maleantes y la oscuridad no es nada fácil. Esta noche Elbia siente especial miedo, ha escuchado que entre los jóvenes de la comunidad las quieren ir a asustar al bosque en el atardecer y ella sabe que, si bien la mayoría de patojos de la comunidad son amables, estos no lo son. El papá de uno de ellos tiene negocios y quiere obligar a su papá a trabajar con él. Luego de pensar y pensar qué hacer y cómo protegerse y proteger a sus hermanas, Elbia siente que está sola, no quiere preocupar a su mamá y no tiene a quien pedir ayuda. Termina por llamar a sus hermanas y camino al bosque ir rezando, pide protección. 


\section{Eligiendo con cuidado las palabras para hacer valer mis derechos}

- Una compañera te pide copia en un examen.

- Necesitas pedir a tus padres de familia un permiso que saben es difícil que les den.

Negociar con su papá que ud. quiere seguir en la Escuela.

- Tu novio te invita a ir donde no hay gente y puedas estar sola en la oscuridad con un muchacho.

- Te han dicho que no puedes participar por ser mujer y que te iría mejor estando en tu casa.

Ya no quieres tener más hijos pero tu pareja insiste en que sí. 


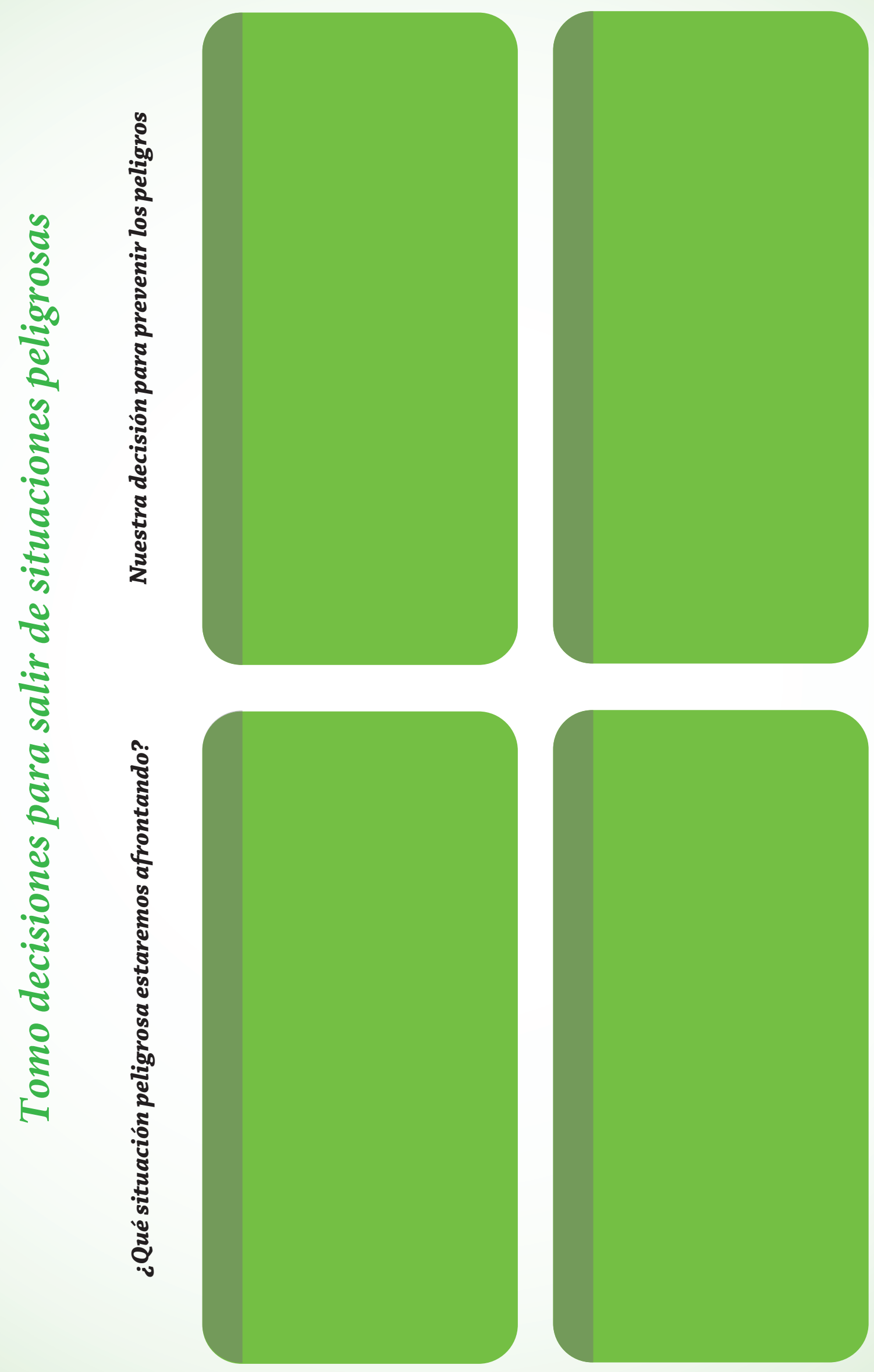



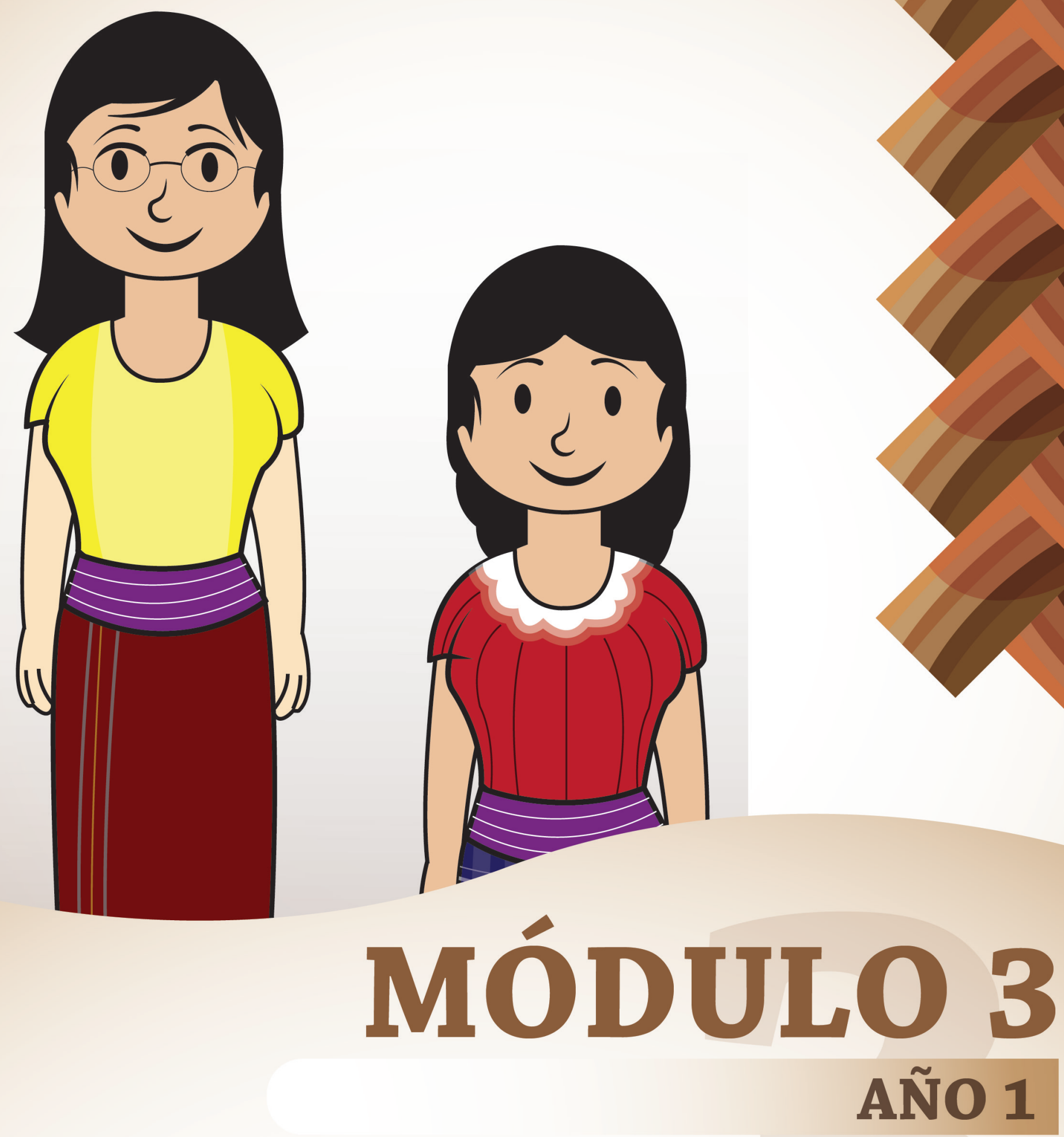

Guía Curricular Integrada 2015 - Population Council 


\section{Créditos}

- Autoras:

- María Cecilia Garcés de Marcilla/Especialista en Educación

$\checkmark$ Paola Broll / Oficial del Programa

- Revisión: Alejandra Munguía/ Coordinador de Campo

- Diagramación:Isaí de la Cruz

- Equipo Population Council 2015:

- Directora de Programas: Alejandra Colom

\ Supervisor de Monitoreo y Evaluación y oficial de Programa: Ángel del Valle

- Administradora: Ana Lucía Rodríguez

- Mentoras: Elizabeth Vásquez, Claudia Macz, Sonia Chó, Patricia Alva, Maribel Gutiérrez, Fabiola Colop y Rosa Güit 


\section{AÑ̃o 1}

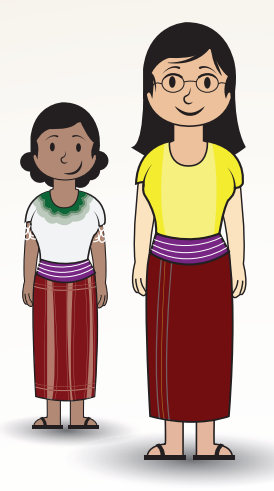

Este trimestre cierra el primer año de trabajo de la guía curricular de Abriendo Oportunidades. Durante este período es importante que las jóvenes puedan recordar y utilizar los conocimientos y las habilidades que han desarrollado para fortalecer su capacidad de tomar decisiones sobre su propia vida. Para apoyar a las niñas en su transición a la adolescencia se trabajan temas de la sexualidad que abordan los cambios en su cuerpo, la higiene, los sentimientos hacia sí mismas y la construcción de relaciones respetuosas. Se reafirman como mujeres con la capacidad y el derecho de tomar decisiones libres e informadas sobre su vida. Además se introduce la sororidad como una nueva forma de relacionamiento entre mujeres, fundamentada en el reconocimiento que comparten retos y que más que competir entre ellas pueden aliarse y fortalecerse como grupo.

\section{Módulo III Grupo de 8 a 12}

3.1 Salud sexual y reproductiva: Salud e higiene

3.2 Salud sexual y reproductiva: Cambios de nuestro cuerpo cuando crecemos

3.3 Salud sexual y reproductiva: El ciclo menstrual

3.4 Género: ¡Yo soy niña y sí puedo!

3.5 Género: Mis amigas y yo tenemos mucho en común

\section{Módulo III Grupo de 13 a 17}

3.1 Salud sexual y reproductiva: salud sexual y reproductiva

3.2 Salud sexual y reproductiva: Anatomía de los órganos sexuales femeninos

3.3 Salud sexual y reproductiva: Cambios del cuerpo durante la pubertad y el ciclo menstrual

3.4 Género: ¿Cómo es y cómo nos han enseñado a ser mujer?

3.5 Género: La sororidad es una nueva forma de relacionarnos

3.6 Fortalecimiento personal: Respeto la dignidad cuando me comunico 
Al finalizar

la sesión las

participantes

habrán...
- Reconocido las partes de su cuerpo por su nombre científico.

- Nombrado formas de cuidar la salud de su cuerpo.

- Comparado el cuerpo de las niñas con el cuerpo de los niños identificando las diferencias en los órganos sexuales de cada uno.

- Identificado las personas en su entorno que les cuidan y respetan.

- Mencionado hábitos de higiene.

\section{Conceptos Clave}

Condiciones para la salud de la niña:

- Una niña saludable no solo no está enferma sino que además es feliz

- Le gusta jugar, estudiar, se siente bien y querida

- Para esto las niñas necesitan: comer sano, tomar agua potable y/o hervida, hacer ejercicio, descansar, jugar, recibir cariño de su familia y comunidad

Órganos sexuales femeninos:

- Son órganos que tienen las niñas y las mujeres en su cuerpo

- Estos órganos ayudan en su proceso de maduración y diferencia a las niñas de los niños

Rompecabezas, siluetas del cuerpo de una niña y un niño, dibujo con los órganos internos de l cuerpo de un niño y una niña, imagen de una niña sana y niña enferma

\section{Bienvenida}

Dé la bienvenida a las participantes, confirmando quiénes están presentes o ausentes. Invítelas a jugar un juego donde van a usar TODO su cuerpo. Empiece por jugar con ellas "simón dice". Explique que usted dirá movimientos que ellas tienen que hacer y seguir, siempre empezará por decir "Simón dice que..." deben escuchar muy bien porque cuando no digas "simón dice" ellas se deben quedar congeladas sin moverse. Asegúrese de incluir todas las partes del cuerpo en la actividad. Algunas que puede realizar son:

"Simón dice que brinquen bien alto levantando los pies en el aire"

"Simón dice que muevan sus manos como milpas en el cielo"

"Simón dice que muevan sus caderas como el agua de un río"

"Simón dice que muevan su cabeza como lo hace una gallina"

"Simón dice que doblen sus rodillas para tocar el suelo con sus manos" 
"Simón dice que caminen como un gallo, sacando el pecho para el frente"

"Simón dice que caminen para atrás moviendo sus nalgas"

"Simón dice que le toquen el hombro a una compañera"

Siga jugando intercalando instrucciones con "simón dice" e instrucciones que no lo tienen.

Al finalizar el juego pregunte:

\author{
¿Cómo se sienten? \\ ¿Nombren las partes del cuerpo usaron? \\ ¿Para qué actividades importantes usan las partes de su cuerpo cada día?
}

\title{
2. Introducción al tema:
}

Distribuya entre las niñas piezas de un rompecabezas de la silueta del cuerpo de una niña. Algunas tendrán piezas con partes del cuerpo y otras tendrán piezas con los nombres del cuerpo. Pida que entre todas armen el rompecabezas. Una vez armado identifiquen y digan los nombres de las partes del cuerpo. Incluye las siguientes partes:

$\begin{array}{llll}\text { 1. } & \text { Cabeza } & \text { 8. } & \text { Cintura } \\ \text { 2. } & \text { Pelo } & 9 . & \text { Ombligo } \\ \text { 3. } & \text { Cuello } & 10 . & \text { Cadera } \\ \text { 4. } & \text { Hombros } & 11 . & \text { Vulva } \\ \text { 5. } & \text { Manos } & 12 . & \text { Muslos } \\ \text { 6. } & \text { Brazos } & 13 . & \text { Glúteos } \\ \text { 7. } & \text { Pechos } & 14 . & \text { Rodillas } \\ & & 15 . & \text { Pies }\end{array}$

\section{Teorizar y definir:}

A la par de ese rompecabezas coloca el dibujo del interior del cuerpo de una niña y de un niño. Pregunte a las participantes:

¿Qué similitudes hay entre los dos cuerpos que ven al frente?

¿Qué diferencias hay entre los dos cuerpos que ven al frente?

¿Cuál es de una niña?

¿Cuál es de un niño?

Poniendo énfasis en el cuerpo de la niña, circule el área de los órganos sexuales femeninos. Coloque carteles en cada uno de los órganos contando a las niñas cuál es la función de cada uno.

Útero: Órgano con forma de pera del tamaño de un puño, localizado en la región pélvica. En él se desarrolla el feto durante el embarazo.

Trompas de Falopio: Son dos conductos largos a cada lado del útero. Comunican al útero con los ovarios. El extremo que está cercano a los ovarios tiene forma de flor. Por ellas pasa el óvulo camino al útero. 
Ovarios: Son dos órganos con forma ovalada que se encuentran en el extremo de las trompas de Falopio. Almacenan los óvulos y producen la secreción de las hormonas femeninas.

Vagina: Canal que se extiende desde la vulva hasta el útero, es un órgano musculoso muy elástico que puede estirarse durante el acto sexual o durante el parto.

\section{Siga preguntando:}

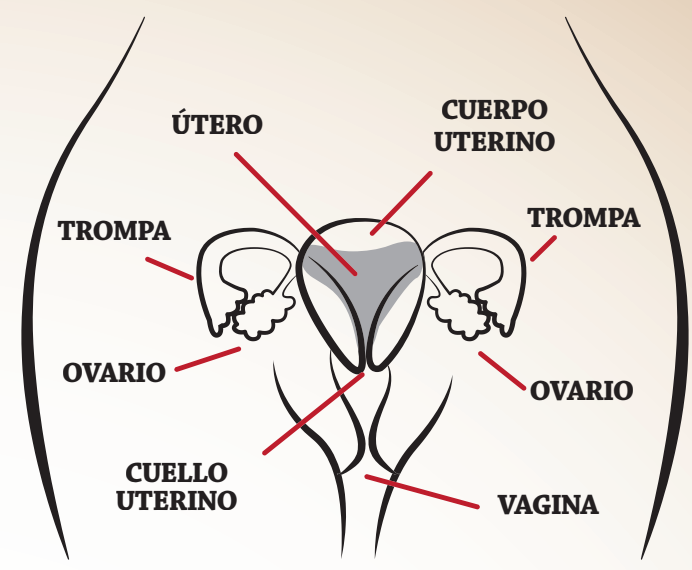

¿Cómo se llaman a estos órganos del cuerpo de las niñas y las mujeres?

\section{¿Para qué sirven?}

¿En qué se parecen al resto de los órganos de nuestro cuerpo?

¿Qué niñas tienen estos órganos?

¿Qué habían escuchado de estos órganos y para qué sirven?

¿Estos órganos nos hacen daño o nos ayudan?

\section{Diga al grupo como conclusión de la actividad:}

Las mujeres pueden sentirse cómodas de conocer y hablar de sus cuerpos para poder así cuidarlos. Estamos aprendiendo a hablar de nuestro cuerpo y a cuidar nuestra higiene para estar saludables. Todos los órganos de nuestro cuerpo nos sirven para crecer, desarrollarnos y ser felices. Vamos ahora a ver cómo cuidar nuestro cuerpo.

Coloque al frente el dibujo de unas niñas sanas y el de unas niñas enfermas y pregunte a las niñas que encuentren las diferencias entre ambas niñas. Apunte las características de las niñas sanas en un papelógrafo. Puede usar la siguiente tabla de referencia para las características de las niñas sanas y las niñas enfermas:

\section{Niñas Sanas}

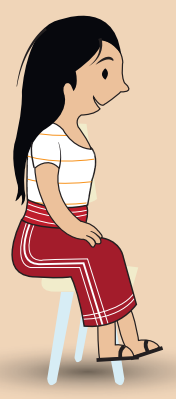

- Peso adecuado

Piel colorida y sana

Feliz en relación con otras niñas

Estatura desarrollada

- Dientes completos y limpios

- Ojos abiertos y brillantes

Pelo abundante y colorido

Buena respiración

Aprende lo que le enseñan en la escuela

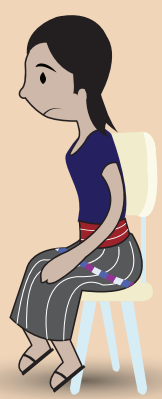

\section{Niñas Enfermas}

Sobrepeso o extremadamente delgada

Piel con manchas descoloridas y ronchas o infecciones de piel

Triste, solitaria, no se relaciona

Estatura limitada

Dientes incompletos y sucios

Ojos opacos, con ojeras

Pelo delgado, escaso y con manchas descoloridas

Tos o dificultad para respirar

Ronchas o infecciones de piel 


\section{Pregunte al grupo:}

¿Qué acciones hacen que una niña se mantenga feliz?

- Comer alimentos variados y limpios, no tantas chucherías sino que más frutas y proteínas, hierbas, carnes y verduras

\section{- Descansar bien}

- Mantenerse limpia

- Hacer ejercicios

- Jugar

- Usar agua y jabón para lavarse el área genital y la vulva todos los días.

- No insertarse cosas en la vagina.

- Evitar golpes en el área

- No permitir que otras personas toquen o entren en contacto con tu cuerpo cuando tú no lo deseas.

- Cambiar la ropa interior todos los días.

- Sentirse querida y especial

- Tener amigas y personas en quien puede confiar

\section{Aplicación para la vida:}

Para terminar, recuérdeles que su salud es un tesoro gigante, que incluye no sólo el cuerpo sino que también sus emociones, su inteligencia, sus sueños. Este tesoro que es su salud debe ser respetado y nadie más puede tocar o usar su cuerpo, ni hacerla sentir incómoda.

Entregue a cada una la hoja de trabajo "Salud de las niñas" en la que deben dibujarse a sí mismas. Y deben escribir los nombres de las personas que les cuidan quieren, respetan y protegen como un círculo que las protege. Fuera del círculo escriben las cosas que les ponen en riesgo.

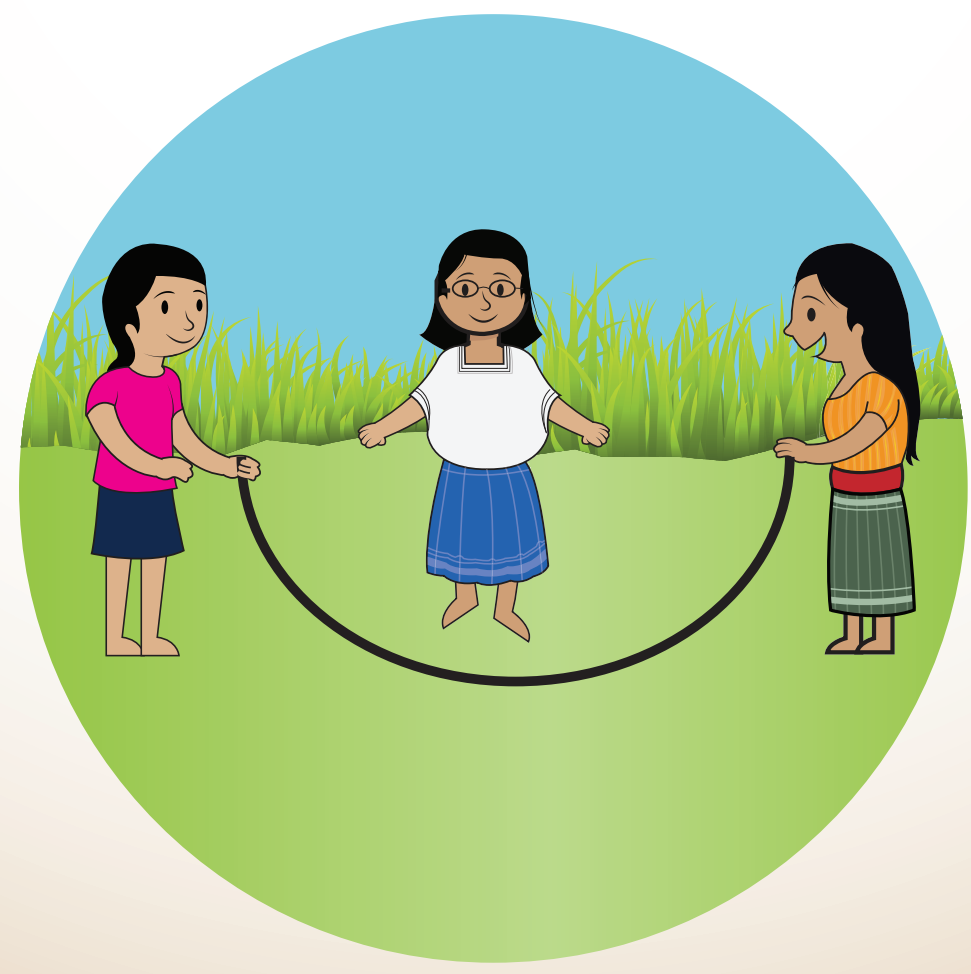




\section{SALUD DE LAS NIÑAS}

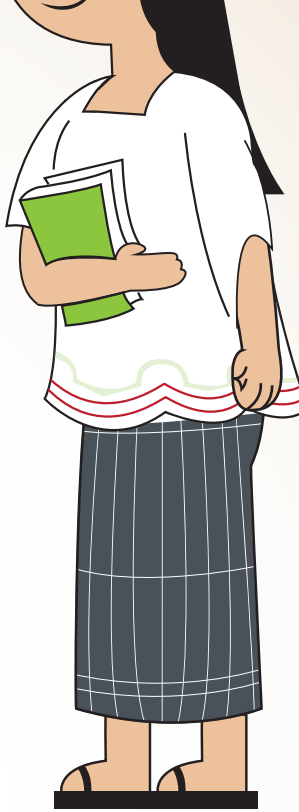




\subsection{Cambios de nuestro cuerpo cuando crecemos}

Al finalizar la sesión las participantes habrán...
Comprendido que cuando las niñas maduran, sus cuerpos y sus relaciones cambian y eso es totalmente natural.

Nombrado algunos de los cambios normales que se dan en la vida de las niñas cuando pasan a ser adolescentes.

\section{Conceptos Clave}

Maduración: es un proceso de cambio que se da en la vida de todos los seres vivos. En las personas se ven cambios en los cuerpos, las emociones, las formas de actuar de niñas y niños que pasan a ser adolescentes. Después de la maduración los cuerpos de las personas están preparándose para convertirse en mamá o papá.

Cambios en el cuerpo: de una niña durante la pubertad incluyen:

${ }^{*}$ crecimiento de vello púbico y en axilas

* crecimiento de los senos

* ensanchamiento de las caderas

* menstruación

* madurez física para quedar embarazada

\section{Marcadores}

- Crayones

Papeles para las mímicas que describan a:

- Bebé, Niña que empieza a caminar, una niña en su primer día en la escuela, joven que encuentra a un chico que le gusta, joven que entra a diversificado y una señora adulta que comercia su cosecha

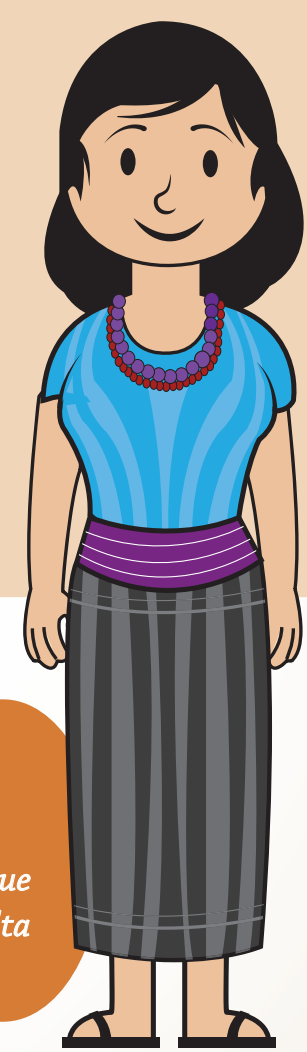

\section{Bienvenida:}

Dé la bienvenida del día a las participantes, confirmando quiénes están presentes o ausentes. Empiece la sesión jugando mímica. Cinco voluntarias tomarán un papel que describa una etapa en la vida de una niña. Al tener su papel harán la dramatización que les tocó sin hablar. Sus compañeras deben adivinar qué está pasándoles a la niña. Una vez han adivinado a todas, coloque los papeles a la vista de las niñas y pida que entre todas los pongan en el orden en que se estarán dando. 


\section{Introducción del tema:}

Juegue con ellas a encontrar las similitudes y las diferencias. Coloque al frente dos papelógrafos con las siluetas del cuerpo de una niña desde que es niña hasta que es adulta (niña, adolescente, adulta). Pida que pasen a señalar sobre los dibujos las cosas que son similares entre una silueta y otra. Motive a que muestren la mayor cantidad posible. Luego pida que con flechas s eñalen las que $s$ on diferentes y también anímelas a identificar todas las cosas posibles.

\section{Al terminar pregunte:}

¿Qué hay más similitudes o diferencias?

¿Qué partes de nuestro cuerpo cambian cuando crecemos?

¿Además del cuerpo, qué otras cosas cambian en la vida de las niñas cuando pasan a ser adolescentes?

\section{Teorizar y definir:}

Tanto en la vida de las mujeres como la vida de los hombres se dan cambios en el cuerpo y estos vienen acompañados de cambios en la conducta, en las responsabilidades, en la relación con otras personas etc. Para la época de la pubertad se marcan cambios más evidentes en el cuerpo y es importante conocerlos pues marcan el inicio de la vida reproductiva.

\section{¿Cuáles cambios se dan en el cuerpo para la pubertad?}

El período de cambios en la adolescencia se llama "pubertad." Estos cambios empiezan en el cuerpo porque el cuerpo está madurando en preparación para la etapa de reproducción.

La Pubertad - es la época de la vida en que la joven empieza a tener cambios físicos, el inicio de la menstruación y la madurez sexual.

Escriba los cambios en un papelógrafo para que queden a la vista.

\section{Mujeres}

- Aparece pelo en las axilas, piernas, y área púbica en los órganos genitales externos.

- Crecen los senos

- Las caderas se redondean

- Se presenta la menstruación

Aparecen granos en la cara y el cuerpo

\section{Aplicación a la vida:}

Junto con los cambios en el cuerpo se presentan cambios en la forma de comportarse, en las relaciones, en los trabajos, en las actividades etc. Ahora vamos a ver cómo se dan esos cambios aquí en la comunidad. Ustedes van a formar cuatro grupos, a cada uno le corresponde dramatizar a sus compañeras la vida en una de las cuatro etapas de desarrollo, sin decir cuál es. Sus compañeras van a adivinar a cuál etapa se refieren. 


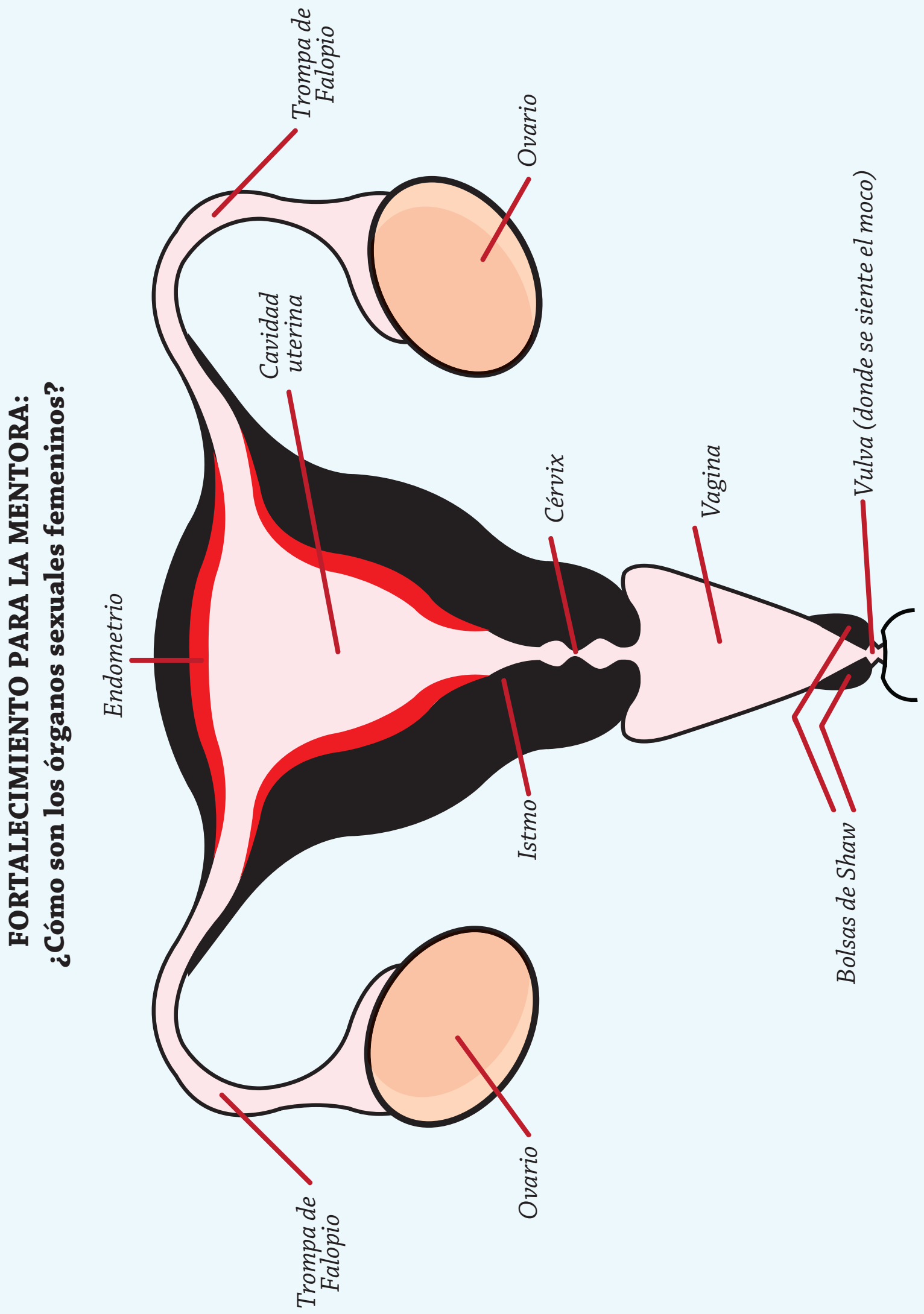




\section{Al finalizar la sesión las participantes habrán...}

- Conocido que el ciclo menstrual es totalmente natural y sano.

- Conocido las prácticas de higiene básicas para tener durante el ciclo menstrual.

- Identificado los mitos y las verdades sobre el ciclo menstrual.

\section{Conceptos Clave}

Menarquia:

La primera menstruación

Ciclo menstrual:

Ciclo hormonal que produce la menstruación.

Menstruación:

El momento en que el cuerpo completa un ciclo menstrual y elimina la sangre del útero.

- Cartel con los órganos sexuales internos femeninos

- Objeto para pasar como papa caliente

- Marcadores

- Hoja de información "Prácticas de higiene"

- Hoja de trabajo ¿Es verdad que?

- Papelógrafos en blanco

- Flechas y dibujos de óvulo y sangre.

- Rótulos de los cuatro pasos.

\section{Bienvenida:}

Dé la bienvenida a las participantes, tomando asistencia y preguntando por quienes están ausentes. Puede felicitar a las que han tenido excelente asistencia durante este trimestre y motivarlas a que sigan así y a las otras que sigan llegando a pesar de las dificultades.

Juegue con ellas papa calienta. Todas se colocan en rueda y se pasarán un objeto de una a otra de forma rápida mientras usted aplaude sin ver al grupo. Cuando pare de aplaudir la que tiene el objeto en sus manos debe compartir una cosa que ha aprendido de su cuerpo, de su vida, de sus amigas en este trimestre. Juegue tres rondas así y luego juegue otras tres en las que ellas preguntan cosas que todavía quieren conocer sobre sus cuerpos.

\section{Técnica de facilitación}

Al inicio usted puede dirigir los aplausos. Cuando ha visto que las niñas comprenden el juego permita que una de ellas sea la que dirige los aplausos. 


\section{Introducción del tema:}

Coloque varias papelógrafos con palabras relacionadas con la menstruación alrededor del salón y pida a las niñas que vean cada uno y escriban en ellos todo lo que conocen sobre el tema. Incluya las siguientes palabras: Menstruación/regla; Cólicos, Toalla Sanitaria, Fertilidad.

Luego de un tiempo pida que todas se coloquen frente a los papelógrafos y lea con ellas lo que han escrito para ir corrigiendo lo que no es correcto, para resolver dudas que puedan tener y para afirmar las ideas que son correctas.

Presente el cartel de los órganos sexuales internos de la mujer para explicar el ciclo menstrual. Diga a las participantes:

Es importante que recordemos como se llaman y funcionan nuestros órganos sexuales porque es allí principalmente en donde se desarrolla el ciclo menstrual. Vamos a jugar como lo hicimos en la sesión pasada. Adivinanzas. Yo les digo la función y ubicación del órgano sexual y ustedes me dicen cuál es y lo vienen a señalar.

Al terminar de señalar todas las partes de los órganos internos puede pasar a ver el tema de la menstruación.

\section{Teorizar y definir:}

Usando el cartel, flechas y pequeños dibujos de un óvulo y gotas de sangre, explique cómo se da el ciclo menstrual de la siguiente forma. Puede escribir los pasos también en un papelógrafo del lado del dibujo de los órganos sexuales. Diga:

a. Aproximadamente cada 28 días, el cerebro manda una señal a un ovario para que expulse un óvulo. Este proceso se llama “ovulación”.

b. El óvulo viaja por una trompa de Falopio hacia el útero.

c. Mientras el óvulo hace ese recorrido que es muy lento, el útero prepara una capa gruesa de sangre.

d. El óvulo llega al úter y allí la capa de sangre del útero se va desprendiendo poco a poco y saliendo del cuerpo. Esta es la menstruación que dura entre 3 y 7 días según cada mujer porque todos nuestros cuerpos son diferentes.

La primera menstruación de una niña se llama MENARQUIA. (escriba esta palabra en un papelógrafo y téngalo a la vista). La menstruación es señal de que nuestro cuerpo ha madurado y esta preparándose para la reproducción. Pero no por ello tenemos que empezar a ser mamás cuando tenemos nuestra primera menstruación. Eso sí necesitamos tener cuidado de nuestra higiene.

Lea en la hoja de información las prácticas de higiene importantes a tener durante los días de la menstruación. Permita tiempo para que hagan todas las preguntas que puedan y quieran. 


\section{Aplicación para la vida:}

Entregue a cada una la hoja de trabajo ¿Es verdad qué? Resolviendo todas juntas cada idea.

\section{¿Es verdad qué...?}

\section{La menstruación es una enfermedad}

\section{Respuesta}

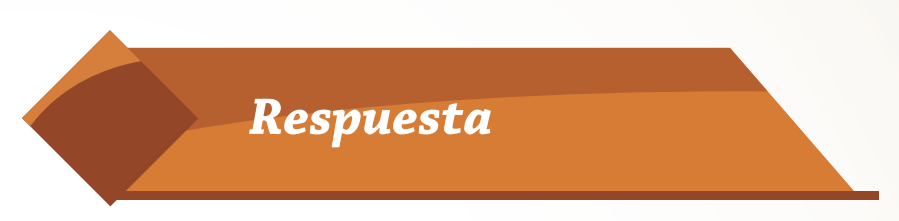

Falso. La menstruación es natural y les pasa a todas las mujeres.

\section{Durante la menstruación tú no debes salir.}

Falso. Durante la menstruación realmente no hay nada que la mujer debe dejar de hacer. Puede salir a caminar, bañarse, jugar, hacer ejercicios y comer de todo.
Durante la menstruación debes bañarte para mantenerte limpia y no le hace daño a tu cuerpo.
Verdadero. Durante la menstruación lo más importante es bañarte todos los días.

\section{Durante la menstruación debes cambiarte la toalla sanitaria por lo menos tres veces al día.}

Verdadero. Para evitar el mal olor y mantenerse limpia debe cambiarse las toallas sanitarias (femeninas) por lo menos tres veces al día.

\section{Una joven puede embarazarse en} la primera relación sexo-genital
Verdadero. En cada relación sexo-genital hay riesgo (peligro) de embarazarse. 


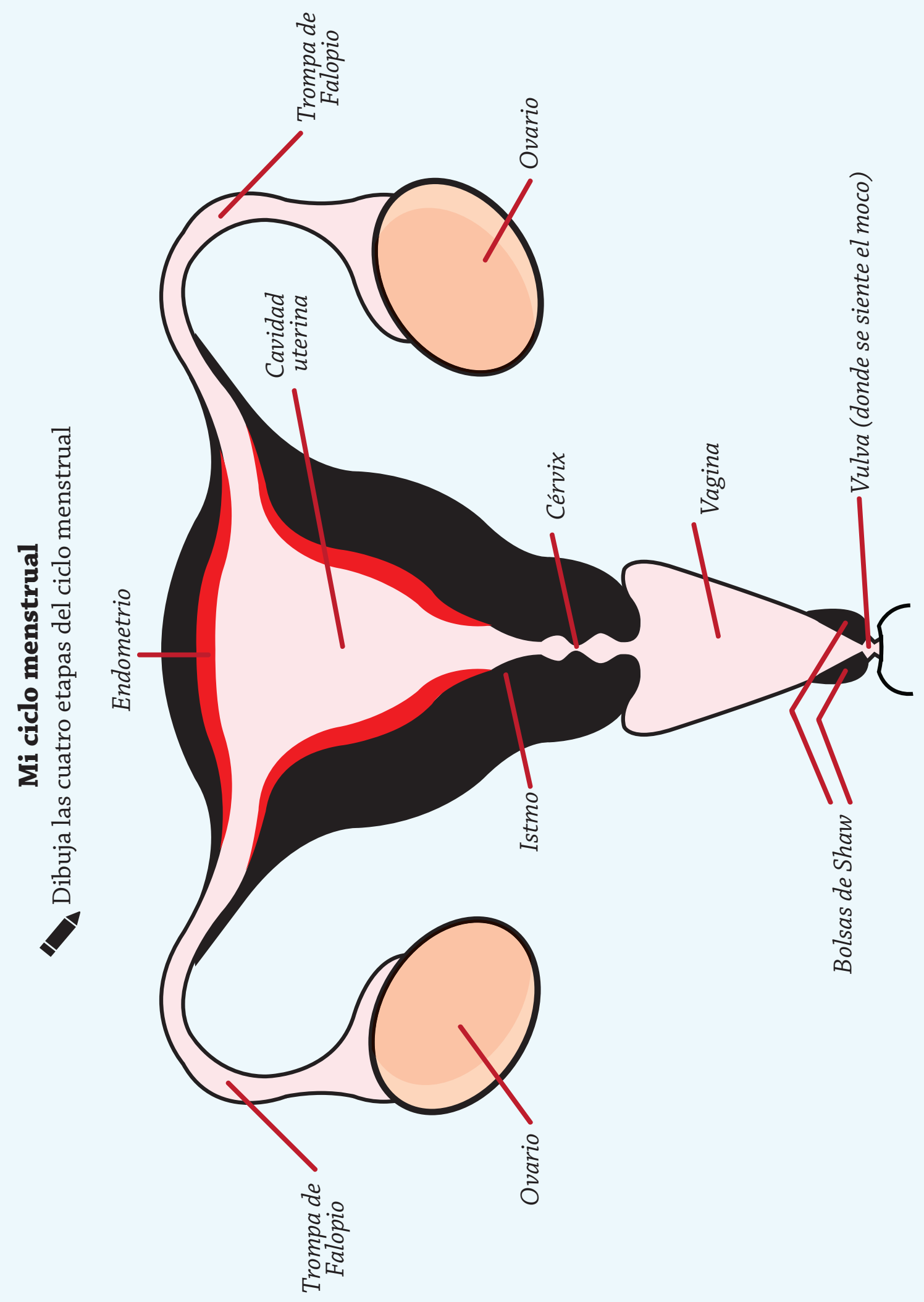




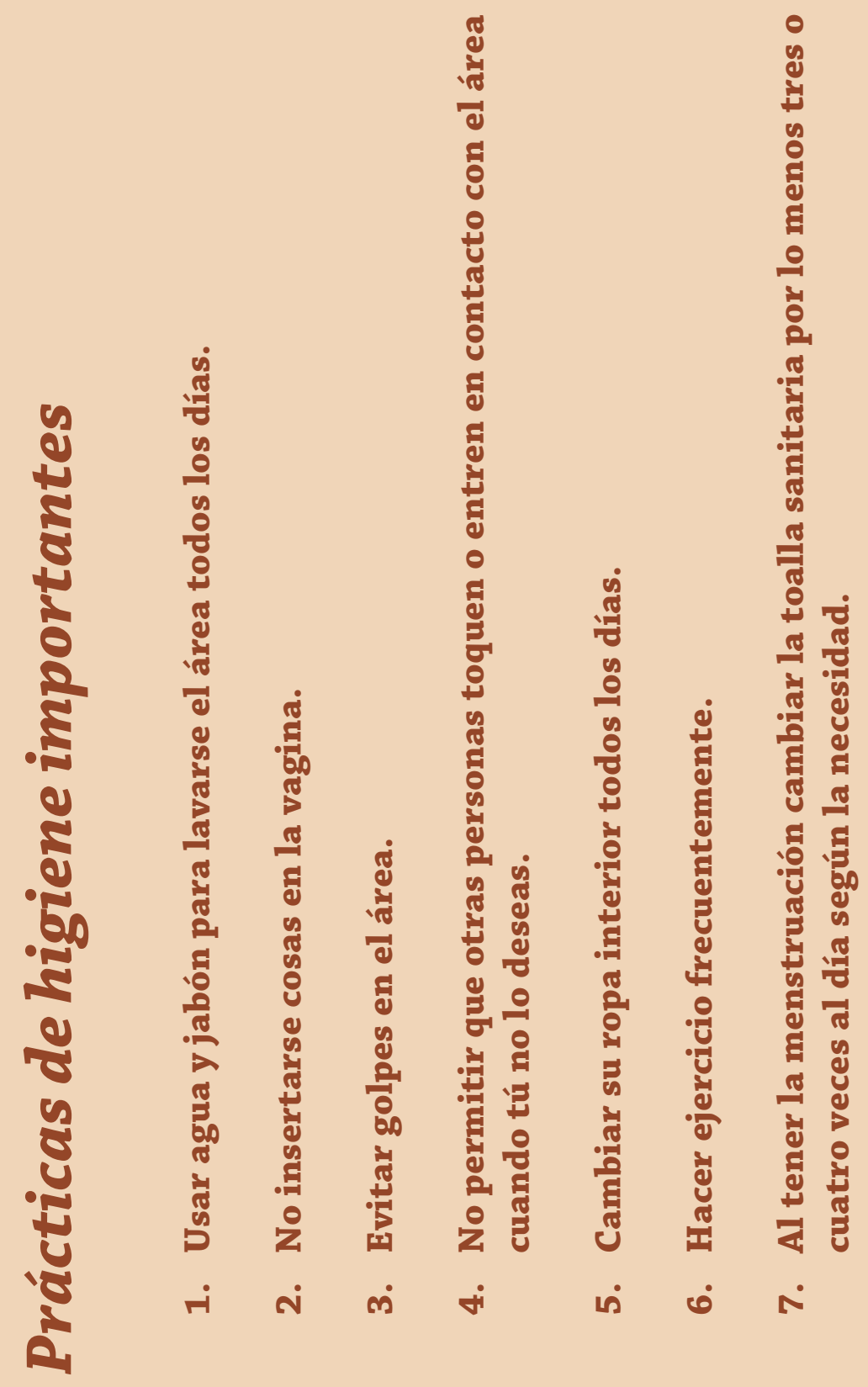




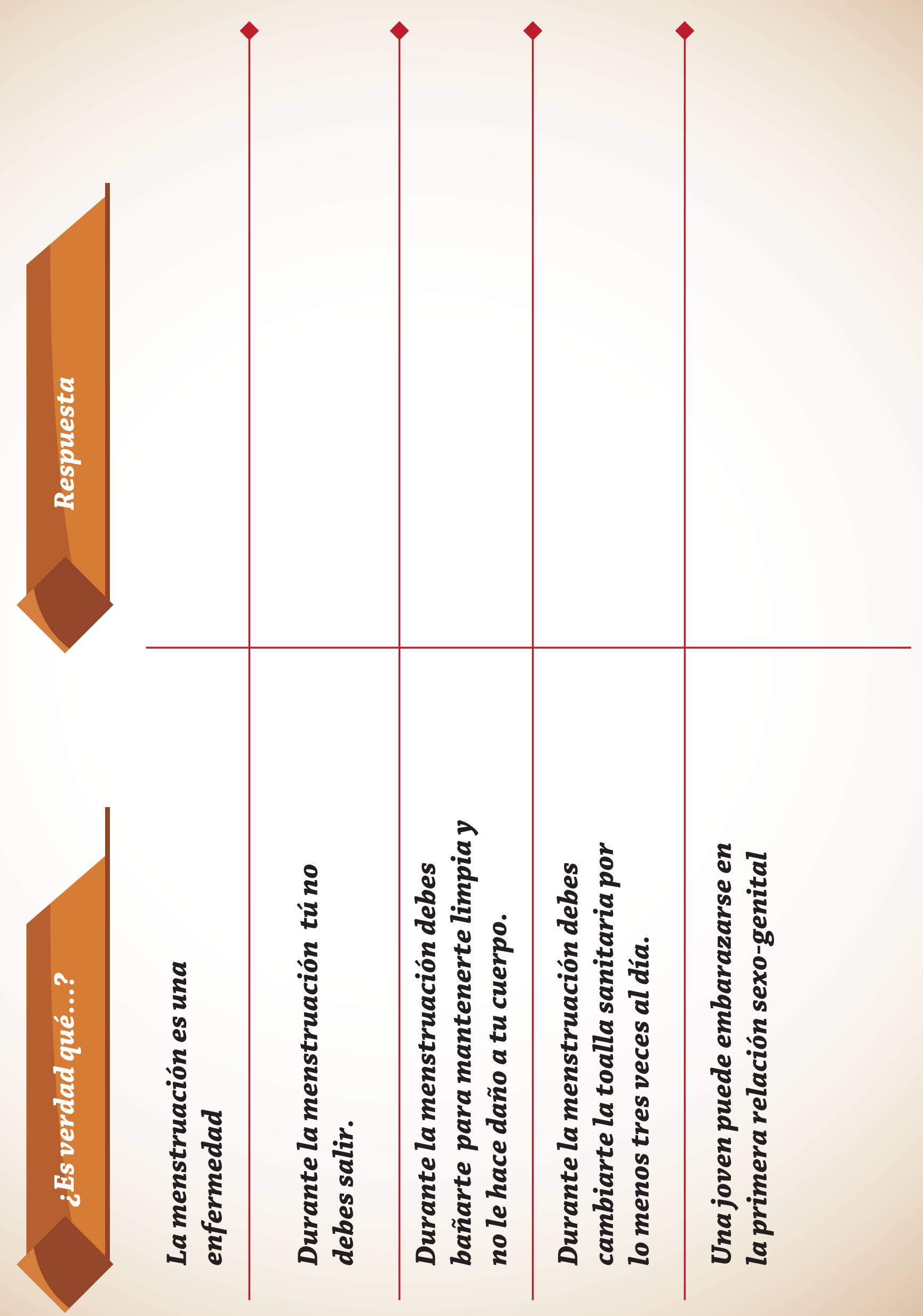




\section{4. iYo soy niña y sí puedo!}

Al finalizar

la sesión las

participantes

habrán...
- Identificado los comportamientos que se les han impuesto por ser niñas.

- Nombrado costumbres e ideas que limitan el desarrollo de las niñas y mujeres.

Pensado en hacer cosas que no son consideradas de mujer pero que les gustan y llama la atención y prueban hacerlas.

\section{Conceptos Clave}

Género:

Características y conductas que se asignan a hombres y mujeres por parte de su comunidad y familia. Las niñas y los niños son diferentes en sus órganos reproductores de todos los otros aspectos son iguales, pero la comunidad les enseña a portarse de diferente forma y hasta pensar que no pueden hacer ciertas cosas por ser niñas y niños. En realidad las niñas y los niños pueden hacer las mismas cosas.

\section{Bienvenida:}

Dé la bienvenida a las participantes, confirmando quiénes están presentes o ausentes, tomando asistencia. Felicita a algunas niñas por los logros que han mostrado a lo largo del módulo, incluso si su asistencia no ha sido excelente esto la puede motivar a seguir llegando. Comparta con ellas que el día de hoy van a pensar y platicar acerca de sí mismas, de ser niñas y de qué les gusta de ser niñas pero también qué límites les ponen por ser niñas.

\section{Introducción del tema:}

Muestre a las participantes el cartel con el dibujo del cuerpo de un niño y de una niña por dentro. 


\section{Pregunte:}

¿Qué ven en el cartel?

¿La última vez que vimos estos dibujos que aprendimos a cerca de las diferencias entre niños y niñas?

¿En cuántas cosas somos iguales que los niños? ¿En cuántas diferentes?

Lleve cartelitos con ropa de niño y de niña, así como juguetes y otros objetos del tamaño de los dibujos de cuerpo de niño y niña, entréguelos a las niñas para que todas las niñas vistan a los muñecos con los carteles y en el cuerpo que corresponde. Puede incluir objetos como los siguientes:

\section{Para niña}

\section{Para niño}

$$
\begin{aligned}
& \text { Güipil } \\
& \text { Corte } \\
& \text { Faja } \\
& \text { Delantal } \\
& \text { Sandalias } \\
& \text { Comal } \\
& \text { Muñeca } \\
& \text { Flores }
\end{aligned}
$$

Playera
Pantalón
Cincho
Zapatos tennis
Calcetines
Gorra
Pelota de fútbol
Machete
Bicicleta

\section{Teorizar y definir:}

Luego de que haya pegado todos los objetos pídales que observen otra vez las diferencias entre niños y niñas y diga:

¿Qué diferencias ven ahora?

¿Estas diferencias las traemos desde que nacemos o cuándo se empiezan a dar? $\mathrm{Si}$ nacemos casi iguales de nuestros cuerpos y con las mismas capacidades

¿Cómo se llegan a dar tantas diferencias entre niños y niñas? 


\section{¿De dónde aprendemos estas diferencias?}

¿Quién dice que las niñas usan rosado y les gustan las flores; y que los niños son fuertes, no lloran $y$ les gusta el fútbol?

Son pocas las características biológicas que diferencian y definen al hombre y la mujer...como la posibilidad de dar de mamar, estar embarazada, o ser papá. Estas definen el sexo de la persona y no van a cambiar nunca. La mayoría de las características están determinadas y decididas por la sociedad. La forma de ser hombre o mujer, actuar como mujer, sus responsabilidades y sus roles, se llama Género. Estos cambian en el tiempo y de una sociedad a otra, hasta de mujer a mujer.

Lamentablemente las ideas de cómo debemos ser las mujeres nos hacen sentir más débiles, pensar que no podemos hacer ciertas cosas, que solo servimos para la casa, los hijos y los maridos. Aunque todo esto no es cierto lo aceptamos y vivimos de esta forma. y los hombres han llevado a que en muchos casos los hombres dominen y maltraten a las mujeres y las mujeres lo acepten. Hasta que todo esto se vuelve costumbre y tradición. Hay personas que han tratado de cambiar estas ideas y de vivir y ser de forma distinta encontrándose con situaciones de violencia y rechazo por parte de la familia, la sociedad y la comunidad.

\section{Aplicación para la vida:}

En un papelógrafo lleve escritas las siguientes ideas que pueden haber en la comunidad acerca de las niñas y los niños (si en su comunidad se manejan otras diferentes cámbielas a lo que sea mejor para su comunidad). Pida que las niñas se reúnan en grupos de tres y después de cada idea que comenten entre ellas si es algo que ayuda al desarrollo o limita el desarrollo de las niñas. Según la respuesta ponga una carita feliz (ayuda al desarrollo) o una triste (limita el desarrollo) a la par de cada frase.

Las niñas son más indefensas y por eso deben estar siempre acompañadas de un hombre que las pueda cuidar.

$\checkmark$ Las mujeres que salen de la comunidad y de casa a trabajar ayudan al desarrollo de su familia.

$\checkmark$ Cuando las niñas se vuelven señoritas no deben estar saliendo solas por allí en la calle.

Las niñas tienen que aprender a ser buenas esposas y mamás que para eso nacieron.

$\checkmark$ Las pelotas, los libros, los carritos son juguetes para niños únicamente.

$\checkmark$ Las muñecas y los trastecitos son juguetes para las nenas.

Las niñas no necesitan estudio porque van a casarse.

La tierra la hereda los hijos para mantenerme su familia 
Al finalizar

la sesión las

participantes

habrán...
- Identificado las características, necesidades, alegrías y tristezas que comparten con sus compañeras.

Pensado en cuál debe ser la forma de relacionarse entre ellas al tener tantas cosas en común.

Cooperado entre ellas a través de dinámicas cooperativas.

\section{Conceptos Clave}

\section{Sororidad:}

La forma de relación entre mujeres que reconoce que compartimos muchas características, necesidades y dificultades. Por ello nos ayudaríamos más apoyándonos entre nosotras y no compitiendo y dificultando unas a otras.

\section{- Marcadores}

- Masking Tape

- Papelógrafo con la palabra MUJER para hacer el acróstico

\section{Bienvenida:}

Dé la bienvenida a las participantes, confirmando quiénes están presentes o ausentes, tomando asistencia de una vez. Cuénteles de qué niñas se siente orgullosa por sus logros en este año. Evite repetir a las que ya mencionó y aproveche para nombrar a las que participan menos y necesitan más apoyo. Comparta con ellas que el día de hoy van a platicar sobre las amigas.

\section{Introducción del tema:}

Juegue con las niñas "Pasajeras en la camioneta". Usted va a pedir que se formen en grupos de acuerdo a la cantidad de pasajeras que van en la camioneta diciéndole a las niñas "va una camioneta de \# de pasajeras". Entre cada ronda haga una de las siguientes peguntas para que respondan entre ellas.

Pregunta 1: ¿Qué te gusta mucho jugar con tus compañeras?

Pregunta 2: ¿Qué te hace sentir muy triste?

Pregunta 3: ¿Qué te gustaría ser de grande?

Pregunta 4: ¿Cómo te sientes cuando no te dejan hacer algo por ser niña? 


\title{
3. Teorizar y definir
}

\section{Al terminar el ejercicio pídales que se sienten en círculo y pregunte:}

\author{
¿Qué aprendieron de sus compañeras hoy? \\ ¿Qué aprenden de lo que tienen en común con sus compañeras? \\ ¿Cómo pueden aprender de sus compañeras? \\ ¿Qué tipo de relación quieren tener con sus compañeras? \\ ¿Qué problemas comparten con sus compañeras y otras mujeres de la comunidad? \\ ¿Cómo pueden unir esfuerzos por superar estos problemas?
}

\section{Al terminar de comentar sobre las preguntas diga a las participantes:}

Hace algunos años un grupo de mujeres se dio cuenta de todo lo que compartían, cosas lindas pero también los problemas más fuertes de su vida. Empezaron a pensar que la forma de relacionarse entre las mujeres podría ser diferente ya no competir, criticar y hacer sentir mal a la otra. Vieron que como las mujeres tenemos retos y problemas comunes podríamos más bien ayudar y apoyarnos unas a otras. A esta forma de relacionarnos le llamaron SORORIDAD. En vez de que hubiera muchas mujeres divididas peleando entre ellas, podríamos ser un grupo grande de mujeres que nos apoyamos unas a otras. A veces los chismes son en contra nuestra o bien es a nosotras a las que no están diciendo cosas desagradables también allí es importante creer en nuestro valor y hacernos respetar.

Acróstico de mujeres. Pegue un cartel que diga "mujeres". Invite a las participantes a hacer juntas un acróstico, en el que a cada letra de la palabra mujer le escriban un problema o reto que comparten con las mujeres de su comunidad. Pregunte a las participantes:

¿Qué miedos tenemos las mujeres para afrontar los problemas?

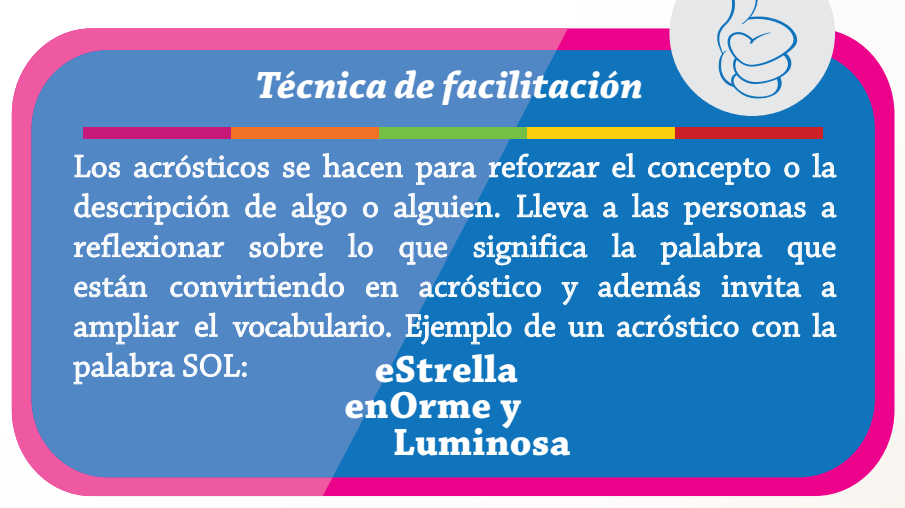

¿Cuándo se unen las mujeres para resolver sus problemas qué puede pasar? ¿Cómo han visto que unas mujeres apoyan a otras?

\section{Aplicación a la vida:}

Realice dos juegos cooperativos entre las niñas, donde puedan identificar que el trabajo en equipo, con buena comunicación y respeto, les permite mejores resultados para resolver un reto. 
Al finalizar

la sesión las

participantes

habrán...
Conocido y usado los términos anatómicos y fisiológicos correctos.

Presentado sus dudas acerca de la sexualidad e investigado en diversos recursos para la finalidad.

Identificado que son libres de conocer, decidir y actuar para cuidar su bienestar.

Identificado mitos y realidades acerca de la sexualidad y el derecho a hablar sobre su sexualidad.

\section{Conceptos Clave}

Salud sexual y reproductiva: es un proceso continuo de bienestar físico, psicológico y sociocultural relacionado con la sexualidad, se evidencia en las expresiones libres y responsables de capacidades sexuales que conducen al bienestar personal y social, enriqueciendo la vida individual y social. Para poder conseguir y mantener la salud sexual es necesario que se reconozcan y defiendan los derechos sexuales de todas las personas (OPS/OMS,2000).

Etapa reproductiva: Etapa de la vida en la cual el cuerpo de la joven a madurado y puede iniciar su reproducción.

Prevención de Mortalidad Materna: Acciones que protegen a las jóvenes en edad reproductiva de entrar en situaciones vinculadas a la maternidad que ponen en riesgo su vida.

\section{Bienvenida:}

Dé la bienvenida a las participantes, confirmando quiénes están presentes o ausentes. Dígales que hoy necesitan tener la lengua floja para poder hablar de todas las cosas que hace nuestro cuerpo y empiece por jugar con ellas una jerigonza o un trabalenguas.

\section{Introducción del tema:}

Realice un diálogo del círculo de confianza. Ponga a las participantes en rueda con usted entre ellas y de tiempo para que platiquen sobre lo que significa en su comunidad dejar de ser niñas y empezar a ser jóvenes. Algunas preguntas que puede lanzar son: 


\section{¿Por qué es tan divertida esta actividad?}

¿Qué cambios hay en la vida cuando las niñas dejan de ser niñas y son jóvenes en esta comunidad?

\section{¿Cómo se mejora su vida?}

¿Qué riesgos nuevos tienen?

¿Qué miedos han tenido ustedes?

¿Qué casos conocen de jóvenes que su salud se vio afectada por las nuevas actividades que les tocaba hacer?

Agradezca a todas por sus participaciones, respete sus comentarios y permita que sean transparentes y sinceras sin moralizarlas. No las regañe por lo que cuentan ni comparten. Sea comprensiva y abierta a sus experiencias. Al finalizar recalque aquellas experiencias de riesgo que se dan por que las jóvenes empiezan a reproducirse o a empezar su vida sexogenital activa.

\section{Teorizar y definir:}

Lleve en un papelógrafo el concepto de Salud Sexual y Reproductiva y léala con ellas. Luego explíqueles lo siguiente sobre la Salud Sexual y Reproductiva.

La educación sobre la salud sexual y reproductiva implica hablar de cómo se reproducen los humanos y las relaciones entre humanos. Para ustedes es un derecho humano, eso significa que si conocen sobre la salud sexual y reproductiva pueden tener más información y conocimientos para tomar decisiones en sus relaciones con otras personas y también en la vida que quieren construir.

\section{Pregunte:}

¿Cómo se vincula esta definición con los que platicamos que le pasa a las mujeres jóvenes en esta comunidad?

Pida que se formen parejas de amigas. Entregue a cada pareja medio papelógrafo y pida que dibujen allí como se sienten de aprender sobre su sexualidad y reproducción. Debajo de su dibujo harán una lista de preguntas de temas que quieren conocer sobre salud sexual y reproductiva. Insista que todos los sentimientos y que todas las preguntas que tengan están bien y son importantes. Recoja los papelógrafos y coloque todos en un lugar para que todas las compañeras puedan verlos. Tome unos diez minutos para que las participantes pasen a ver el trabajo de todos los demás grupos. 


\title{
Pregunte:
}

\author{
¿Qué sentimientos se expresan? \\ ¿Cuántas preguntas lograron leer? \\ ¿Han aprendido antes de este tema?
}

¿Qué les han dicho en su casa sobre la sexualidad?

¿Qué les han dicho en la escuela?¿Qué les han dicho en la Iglesia?

¿Por qué no es común que se de toda la información a los jóvenes acerca de su cuerpo

sexual?

\section{Aplicación para la vida:}

Cierre con una actividad que permita a las participantes entende estos temas, para que también tengan buenos argumentos de la importancia de conocer sobre su sexualidad. Forme de cuatro a cinco grupos y diga que van a jugar mitos mitos y luego identificarán respuestas verdaderas a esos mitos.

Escriba en papelógrafos mitos que se tienen acerca de la salud sexual que se usan para decir que este tema no se debe hablar entre las jóvenes y las niñas. Algunos mitos pueden ser:

$\rightarrow$ Es un pecado hablar sobre esos temas

$\rightarrow$ Al empezar a conocer sobre los temas las jóvenes van a ir a buscar a sus novios para hacer cosas.

$\rightarrow$ Hablar sobre sexualidad hace que tengan más curiosidad y vayan a probar todos lo que se les ha dicho.

$\rightarrow$ Es un tema solo para hombres, las mujeres no tienen por qué andar conociendo de esto.

$\rightarrow$ Quien habla del tema es porque algo sabe, y ha experimentado y anda teniendo relaciones por allí.

$\rightarrow$ No todas las personas son iguales y entonces no todas necesitan hablar del tema.

$\rightarrow$ Es un tema de familia y solo en la familia se debe hablar.

$\rightarrow$ Es mejor que aprendan con sus amigas o con sus esposos.

Permita que en sus grupos hablen sobre el mito que les tocó e identifiquen que cosas son ciertas y qué cosas no. Mientras ellas hacen eso, pegue en una parte visible del salón otros por qué sí es importante conocer de la sexualidad. 
Algunas ideas de respuestas pueden ser:

Nuestro cuerpo es un regalo maravilloso y lo debemos conocer a fondo para poderlo cuidar y respetar.

$\rightarrow$ La información que se maneja en la calle, la tele, los amigos y amigas, no siempre es verdadera, puede confundir y llevar a cometer errores serios.

La información elimina el morbo y permite tener una actitud sana y responsable.

$\rightarrow$ La sexualidad es un tema para hombres y para mujeres, ambos tenemos sexualidad.

$\rightarrow$ Hay mucha información sobre la sexualidad y la salud sexual disponible en la calle, las escuelas, las bibliotecas etc.

$\rightarrow$ A veces la familia no tiene suficiente información y se necesita que alguien más enseñe del tema con información científica.

Conocer de sexualidad solo significa que se tiene interés en conocer más sobre el cuerpo, la forma de relacionarse.

Conocer de sexualidad permite a las jóvenes ser responsables en sus decisiones.

Pida a los grupos que lean todas las respuestas y sin moverse de su lugar escojan una que sirve para desmentir el papelógrafo que ellas tienen. Espere a que todas hayan seleccionado una respuesta y cuando usted diga ¡Ya! todas deben ir corriendo, con su papelógrafo hacia la frase que escogieron. Estando todas en la respuesta seleccionada, pida que cada grupo exponga la idea que les tocó y lo que escogieron.

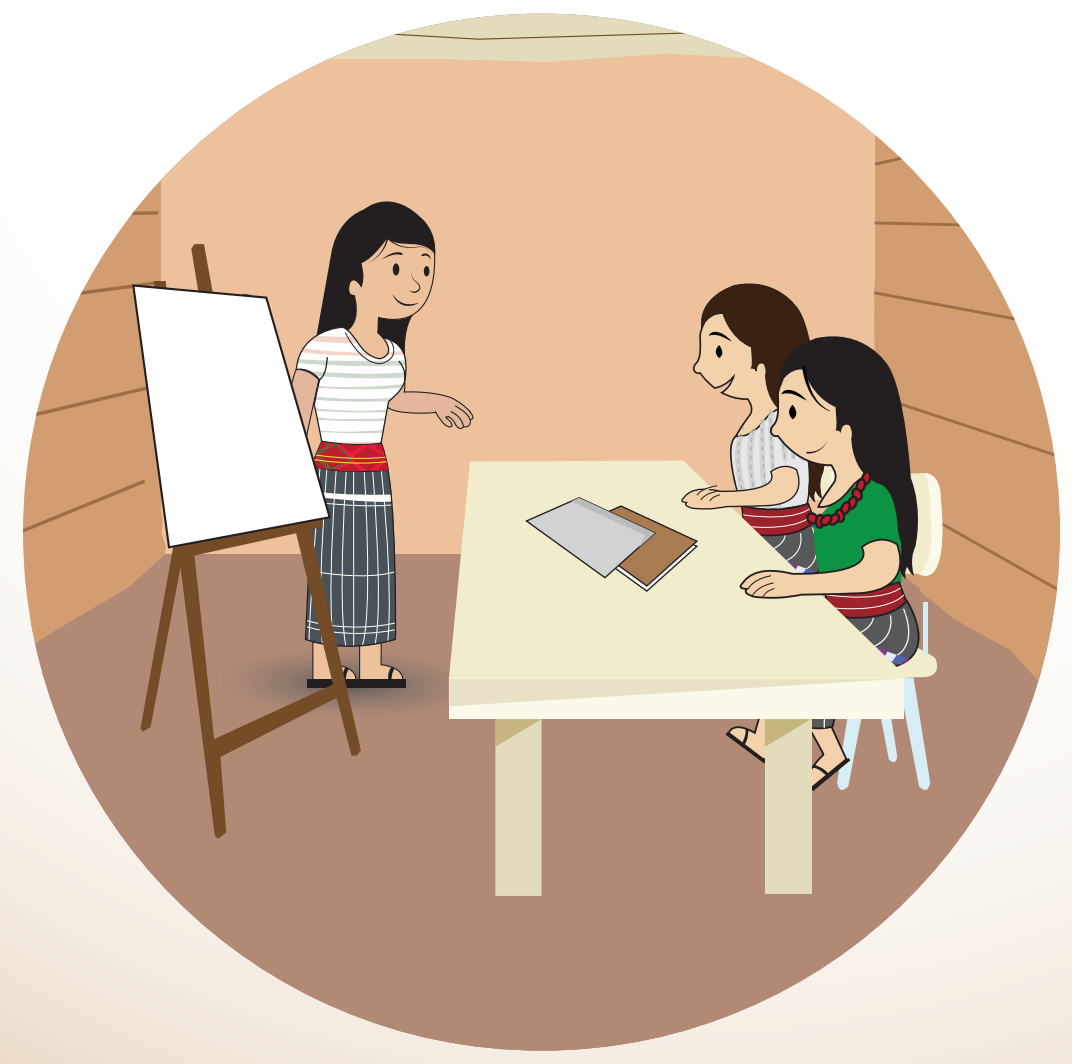




\section{Anatomia de los órganos sexuales femeninos}

Al finalizar

la sesión las

participantes

habrán...
- Conocido los nombres y funciones de los órganos sexuales femeninos internos y externos.

- Identificado los órganos sexuales femeninos.

- Argumentado porqué tienen derecho de conocer acerca de su cuerpo y cómo les permite cuidar su salud.

\section{Conceptos Clave}

Órganos sexuales externos: es el conjunto de órganos sexuales que se encuentran en la parte exterior del cuerpo de la mujer.

Órganos sexuales externos: se encuentran en la parte interior del cuerpo de la mujer.

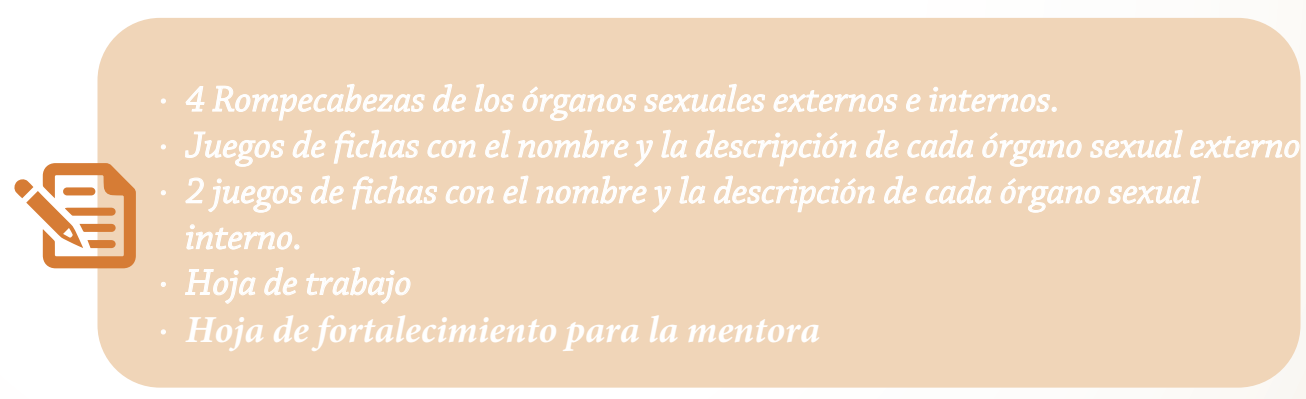

\section{Bienvenida:}

Dé la bienvenida a las participantes, confirmando quiénes están presentes o ausentes. Comparta con ellas que el día de hoy van a conocer acerca de sus cuerpos y empezarán por abrazarse a sí mismas y agradecerle a su cuerpo todo lo que hace por ellas. Pueden pedirles que mencionen cuál es la parte preferida de su cuerpo y porqué la escogieron.

\section{Introducción del tema:}

Haga cuatro grupos entregue a cada grupo un juego de rompecabezas y pida que lo intenten armar. Una vez armado pida que los peguen en un papelógrafo y coloquen de título Órganos sexuales de la mujer. Revise usted que lo haya armado bien antes de que lo peguen.

Entregue a cada grupo una bolsita con fichas que tienen el nombre de los órganos sexuales pida que coloquen cada ficha señalando el órgano que es. 


\section{Teorizar y definir:}

Así como están en grupos entregue a cada participante una copia de la hoja con los órganos sexuales de la mujer y pida que revisen si colocaron bien las fichas de los órganos en la parte que corresponde. Si colocaron alguna ficha en donde no es, la arreglan en ese momento sin problema. Pida que con masking tape peguen las fichas en el lugar donde van.

Regresan todas a sentarse en plenaria. Ponga al frente un cartel grande el dibujo de los órganos sexuales internos y externos. Pida que pasen voluntarias al frente a colocar los rótulos de cada órgano sexual en el lugar que corresponda y pida que las compañeras digan para qué sirve cada órgano que se está señalando.

\section{Aplicación para la vida:}

\section{Pregunte a las participantes:}

¿Qué órganos son nuevos que no conocían antes?

¿Para qué sirven estos órganos sexuales?

Para tener bebés, sentir placer, pero también para el desarrollo de niña a mujer y para estar sanas.

¿Cómo podemos cuidar nuestros órganos sexuales?
Higiene todo el tiempo, no insertarnos cosas, tener cuidado con los golpes, comer
saludablemente, hacer ejercicio.

Dialogue con ellas sobre cómo las mujeres corren riesgos en su vida porque no se les provee información acerca de su cuerpo y ellas hoy están venciendo estos límites. Forme cinco grupos y a cada grupo entregue un papelito en el que hay un mito sobre por qué las mujeres no deben saber sobre sus cuerpos y un papelógrafo. En sus grupos deben leer los papeles y discutir entre ellas qué respuesta pueden dar a esas ideas falsas. Escribirán sus respuestas en un papelógrafo.

Los mitos a escribir son:

1. Las mujeres que saben sobre la sexualidad es porque ya anduvieron experimentando y eso no está bien.

2. Cuando una mujer se casa, su esposo toma las decisiones sobre cuántos hijos tener y cómo planificar. Ella no sabe nada del tema y por eso no puede participar en las decisiones.

3. Cuando hay amor de verdad no hay necesidad de pedir que se usan métodos para no quedar embarazada. La mujer que los pide es porque no ama a su pareja de verdad.

4. La que habla de sexo es porque solo en eso piensa y está buscando como seducir a un hombre para que la mantenga.

5. Las abuelas no le hablaron a las mamás sobre este tema y las mamás están allí no les pasó nada. Tampoco debiera ahora hablárseles a las jóvenes sobre esto temas porque les va dar ideas que no tienen ahora. 
Hoja de fortalecimiento de la mentora: Órganos Sexuales de la Mujer

\section{Órganos sexuales internos}

Monte de Venus: Área protuberante sobre el hueso de la pelvis, luego del desarrollo se recubre de vellos púbicos para proteger los órganos sexuales.

Labios Mayores: Dos pliegues de piel gruesa que protegen la entrada a la vagina.

Labios Menores: Dos pliegues de piel delgada y rojiza que rodean la entrada de la vagina.

No tienen vellos.

Clítoris: Órgano pequeño redondo situado en la parte anterior de los labios menores. Su estimulación provee placer sexual.

Meato Uretral: Orificio por donde sale la orina.

Abertura de la Vagina: Abertura alargada por donde salen las secreciones vaginales, la menstruación y los bebés. Conduce a los órganos internos del sistema reproductor.

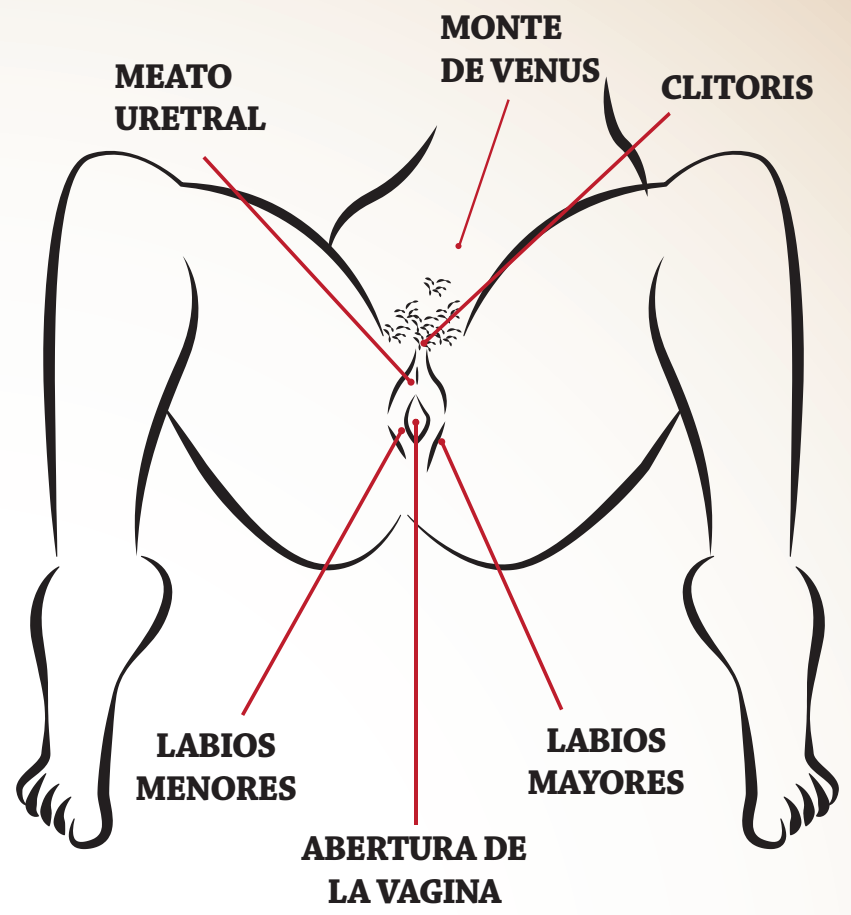

(ECOS, 2011)

\section{Órganos sexuales externos:}

Útero: Órgano con forma de pera del tamaño de un puño, localizado en la región pélvica. En él se desarrolla el feto durante el embarazo.

Cuello Uterino (cérvix): Parte inferior del útero, tiene forma tubular que comunica a la vagina con el útero. Por el pasa la menstruación y los espermatozoides. Al momento del parto se estira para que pueda pasar el bebé.

Trompas de Falopio: Son dos conductos largos a cada lado del útero. Comunican al útero con los ovarios. El extremo que está cercano a los ovarios tiene forma de flor. Por ellas pasa el ovario camino al útero.

Ovarios: Son dos órganos con forma ovalada que se encuentran en el extremo de las trompas de Falopio. Almacenan los óvulos y producen la secreción de las hormonas femeninas.

Vagina: Canal que se extiende desde la vulva hasta el útero, es un órgano musculoso muy elástico que puede estirarse durante el acto sexual o durante el parto.

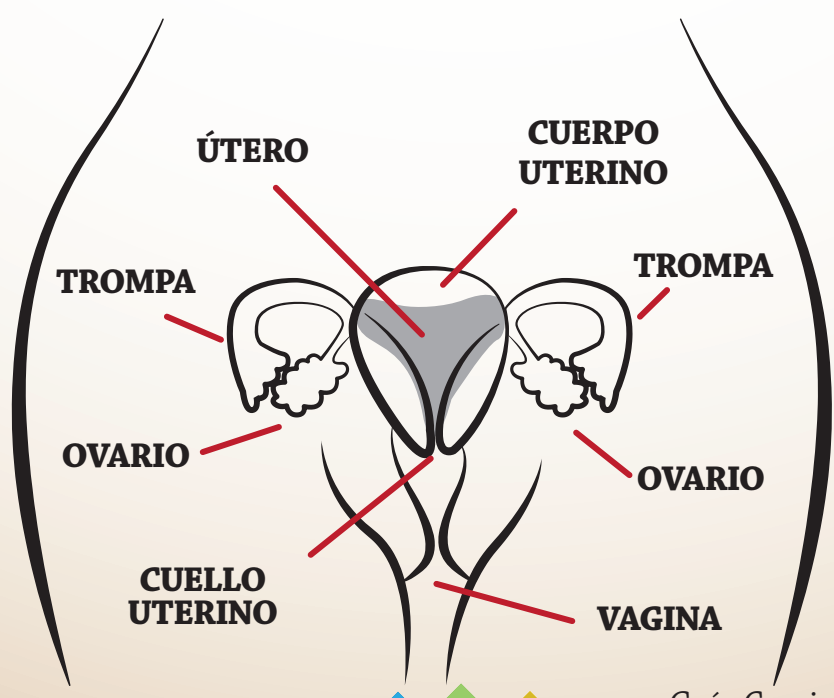

(ECOS, 2011) 

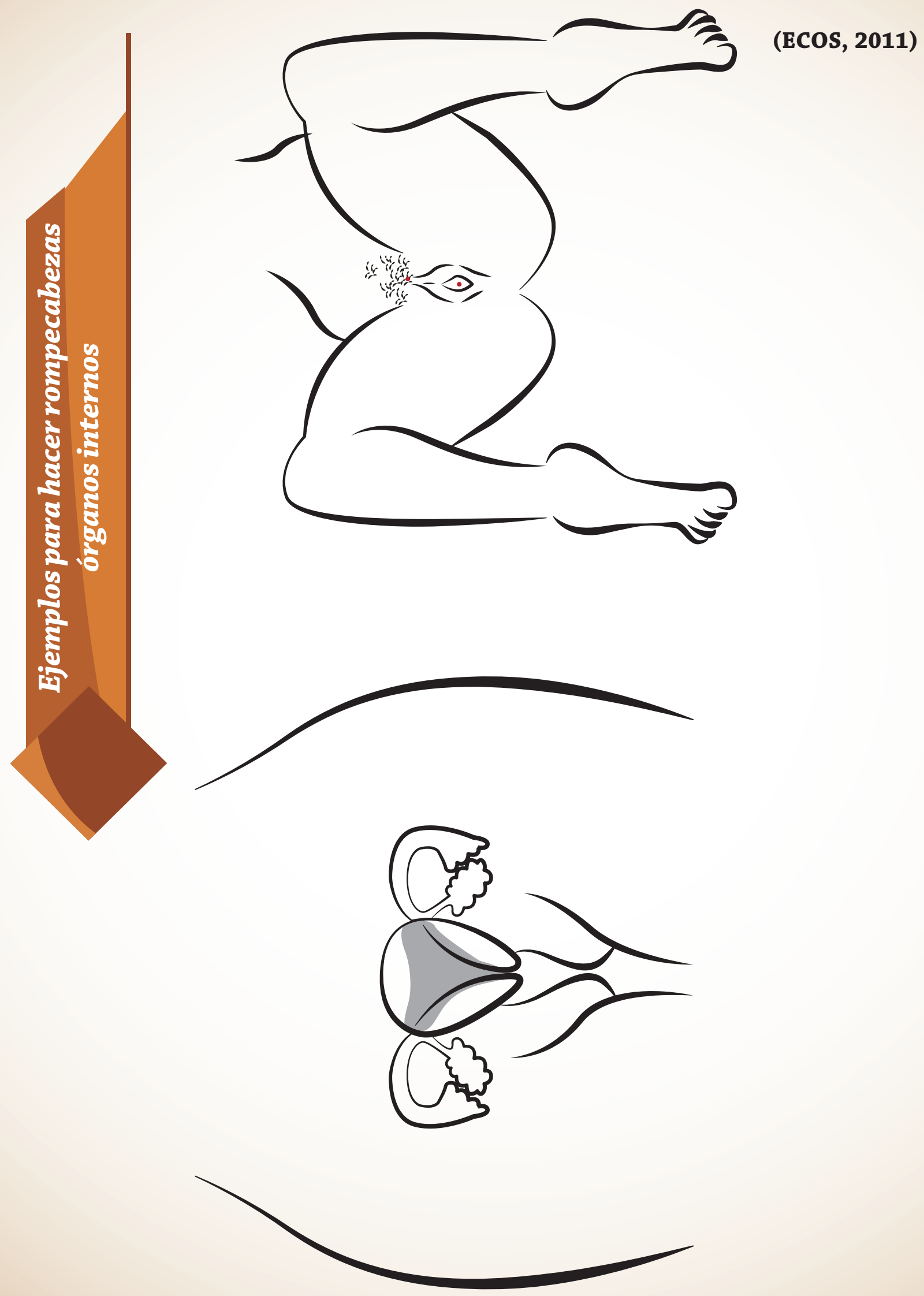


\subsection{Cambios del cuerpo durante la pubertad y el ciclo menstrual}

\section{(b) 2 horas}

Al finalizar

la sesión las participantes habrán...
- Conocido las tres etapas de la vida reproductiva de la mujer.

- Identificado los cambios del cuerpo durante la pubertad.

- Aprendido sobre el ciclo de la menstruación diferenciado mitos y verdades sobre la menstruación

\section{Conceptos Clave}

Etapas de la vida reproductiva: Son la pubertad, reproducción, menopausia.

Menarquia: La primera menstruación.

Ciclo menstrual: Ciclo hormonal que produce la menstruación.

Menopausia: La mujer deja de ovular, no puede quedar embarazada y ve su última menstruación.

Edad fértil: Periodo de la vida en que una mujer puede quedar embarazada, dar a luz y dar de lactar.

Pubertad: Época de la vida en que la joven empieza a tener cambios físicos que le llevan a la madurez sexual.

\section{Papelógrafos con la silueta del cuerpo de una niña, una joven, un madre y una anciana Crayones $y$ marcadores \\ Hoja de trabajo}

Cartel de los órganos sexuales interno y dibujo de óvulo, sangre del endometrio y gotitas de sangre

Papelógrafo en blance

Rótulos de los órganos sexuales internos

\section{Bienvenida:}

Dé la bienvenida a las participantes, confirmando quiénes están presentes o ausentes. Comparta con ellas que el día de hoy van a conocer los cambios que se dan en sus cuerpos y que van a seguirse dando durante varios años en sus vidas.

\section{Introducción al tema:}

Coloque cuatro papelógrafos al frente en desorden: uno con la silueta de una niña, el otro con la silueta de una joven, otro con el cuerpo de una mujer embarazada y el último con el cuerpo de una mujer anciana. Cuente que esa es la silueta de Juana, a lo largo de su vida. Pida que ordenen la silueta según el orden que corresponde. 
Deben formar cuatro grupos, entregue a cada grupo y pida que llenen la silueta dibujando a Juana, su rostro, su ropa, su peinado, las cosas que usa según lo que hace en esa etapa de su vida y la edad que calculan que tiene. Permita que lo trabajen durante quince minutos. Cuando han terminado los grupos de hacer sus dibujos pida que pasen al frente en el orden (niña, joven, madre, anciana) y que cuenten la historia de Juana. Las demás deben irse fijando en qué cambios se presentan en la vida de Juana. Al terminar pregunte:

\section{Técnica de facilitación}

Mientras trabajan en grupos pase motivándolas a que hagan el dibujo lo más completo pueden incluir la casa, la familia, la escuela, las amigas, lo que usa para trabajar, jugar etc.

¿Qué cambios se dan en la vida de Juana en cada etapa?

\section{Escriba las respuestas en un papelógrafo.}

Algunos cambios son en el cuerpo de Juana y otros son en su comportamiento, su forma de relacionarse, sus intereses

¿Cuáles de los cambios son de cuerpo y cuáles son de comportamiento?

\section{Marque en el papelógrafo subrayando los cuerpos que son de cuerpo y circule los cambios que son de comportamiento.}

¿Cómo le llamarían a cada etapa de cambio en la vida de Juana?

- Escriba el nombre correcto de cada etapa en el papelógrafo según corresponde:

- Primer papelógrafo: Niñez

- Segundo papelógrafo: Pubertad

- Tercer papelógrafo: Edad fértil

- Cuarto papelógrafo: Menopausia

¿Cuál es la marca del inicio y el fin de la edad fértil?

La primera menstruación (menarquia) y la última menstruación (menopausia). Coloque un cartel que diga menarquia y otro que diga menopausia en cada cartel.

\section{Teorizar y definir:}

\section{Diga a las participantes:}

Tanto en la vida de las mujeres como la vida de los hombres se dan cambios en el cuerpo y estos vienen acompañados de cambios en la conducta, en las responsabilidades, en la relación con otras personas etc. Para la época de la pubertad se marcan cambios más evidentes en el cuerpo y es importante conocerlos pues marcan el inicio de la vida reproductiva. 


\section{¿Cuáles cambios conocen se dan en el cuerpo para la pubertad?}

Escriba los cambios en un papelógrafo para que queden a la vista, utilice las siluetas de la hoja \# 131

\section{Hombres}

Los hombros se vuelven más anchos

Aparece pelo en las axilas, piernas, bigote,

barba, y área púbica alrededor del pene.

Se desarrollan los órganos sexuales (crece

el pene).

Cambia la voz

- Presenta eyaculaciones

Aparecen granos en la cara y el cuerpo

\section{Mujeres}

Aparece pelo en las axilas, piernas, y área púbica en los órganos genitales externos.

Crecen los senos

Las caderas se redondean

Se presenta la menstruación

Aparecen granos en la cara y el cuerpo

\section{Diga a las participantes:}

El período de cambios en la adolescencia se llama "pubertad." Estos cambios empiezan en el cuerpo porque el cuerpo se está preparando para la etapa de reproducción. El ciclo menstrual es parte central de esta etapa y toda mujer debe conocer cómo funciona el ciclo menstrual. Vamos a conocer cómo se da el ciclo menstrual que se desarrolla principalmente en los órganos sexuales internos de la mujer -usar dibujo de la página \# 132 -

Coloque al frente un cartel grande con los órganos sexuales internos de la mujer y vuelva a repasar con ellas los nombres de cada órgano. Luego inicie la explicación del ciclo menstrual usando el cartel y pequeñas figuras (ovario y sangre) para hacer demostración de la explicación. Diga:

a. Cuando una mujer ha madurado suficiente para quedar embarazada, el cerebro manda todos los meses una señal a los órganos sexuales para que se activen en caso de que la mujer quiera quedar embarazada. Lo primero que sucede es que un óvulo se madura dentro del ovario. (Coloque la imagen de un óvulo verde dentro del ovario para demostrar que está maduro.)

b. Al estar madura el óvulo es capturado por la trompa de Falopio y recorre toda la extensión de la trompa de Falopio. (Mueva el óvulo hacia la trompa de Falopio y haga como que hace el recorrido por la trompa).

c. Mientras esto ocurre dentro del útero el endometrio se engruesa formando una capa gruesa de sangre a su alrededor (coloque una franja roja en la pared del útero, simulando ser el endometrio).

d. Si al llegar el óvulo al útero este no está penetrado por un espermatozoide, se suelta la sangre y se desprende de la pared del útero, convirtiéndose en la menstruación que nosotras vemos. Para ayudar a que la sangre salga el útero se contrae y eso puede provocar dolores o cólicos. (quite las franjas rojas de la pared del útero y haga como que salen por el cuello del útero y la vagina).

e. El sangrado dura de 3 a 7 días. El cuerpo de cada mujer es diferente y por eso no se puede hablar de días exactos entre una menstruación y la siguiente pero pasa más o menos cada 28 días casi cada mes (usar figura página 132: Ciclo mensual 28 días). Cuando una mujer tiene su primera menstruación significa que ya puede concebir un hijo o una hija cada vez que tiene relaciones sexuales. Ya que no se puede saber cuándo va a empezar su primera menstruación, una mujer todavía puede embarazarse antes de tenerla por primera vez. 
Pida que una voluntaria pase al frente y explique el ciclo usando los dibujos, mientras ella explica pida que otra apunte cada fase en un papelógrafo. Si es necesario vuelva a repetir hasta que hayan comprendido todo el proceso.

\section{Aplicación a la vida:}

De espacio para que las participantes le hagan preguntas sobre el tema, en caso no haya quedado claro o tengan más dudas. Diga a las jóvenes que cuando uno está con su regla, puede salir a jugar, a pasear a estudiar, a todo lo que siempre se hace en un día sin regla; entregue a cada participante la hoja de trabajo Ciclo menstrual -calendario, páginas 134 y 135- y diga que es bueno que aprendamos a idenficar la fecha de nuestra menstruación y que en el calendario marquen que día inician y cuando finalizan y que lo realicen por varios meses para identifticar de cuantos días es su ciclo para preparase con lo necesario para el ciclo (toallas sanitarias) .

\section{Haga las siguientes preguntas a las participantes:}

¿Qué es la menstruación?

¿Por qué no debemos sentir vergüenza por la menstruación ?
¿Tres cambios que ocurrieron o están ocurriendo en ustedes ?

¿Qué características tiene un hombre cuando consideramos que es una buena pareja que nos cuida y quiere?

Entregue a las participantes la hoja de trabajo ¿Es verdad que...?

Diga a las jóvenes que van a trabajar en parejas (forme las parejas) para identificar si lo que las personas dicen acerca de la menstruación es verdad o no. Pueden platicar con su pareja para tener más información y entonces decidir su respuesta. Si lo que está escrito en la columna ¿Es verdad que...? es correcto pueden dibujar una cara feliz en el espacio de la derecha, en la columna "respuesta". Si la información no es correcta, ellas deben escribir lo que es correcto. Pídales que hagan el ejercicio con lápiz para revisar sus respuestas después y que puedan borrar en caso tengan que corregir algo. Cuando las jóvenes terminen pregunte qué escribieron en cada pregunta y oriente sobre la respuesta correcta.

\section{Siluetas a utilizar en el papelógrafo "cambios que se dan en el cuerpo", mencionado en la página \#130}
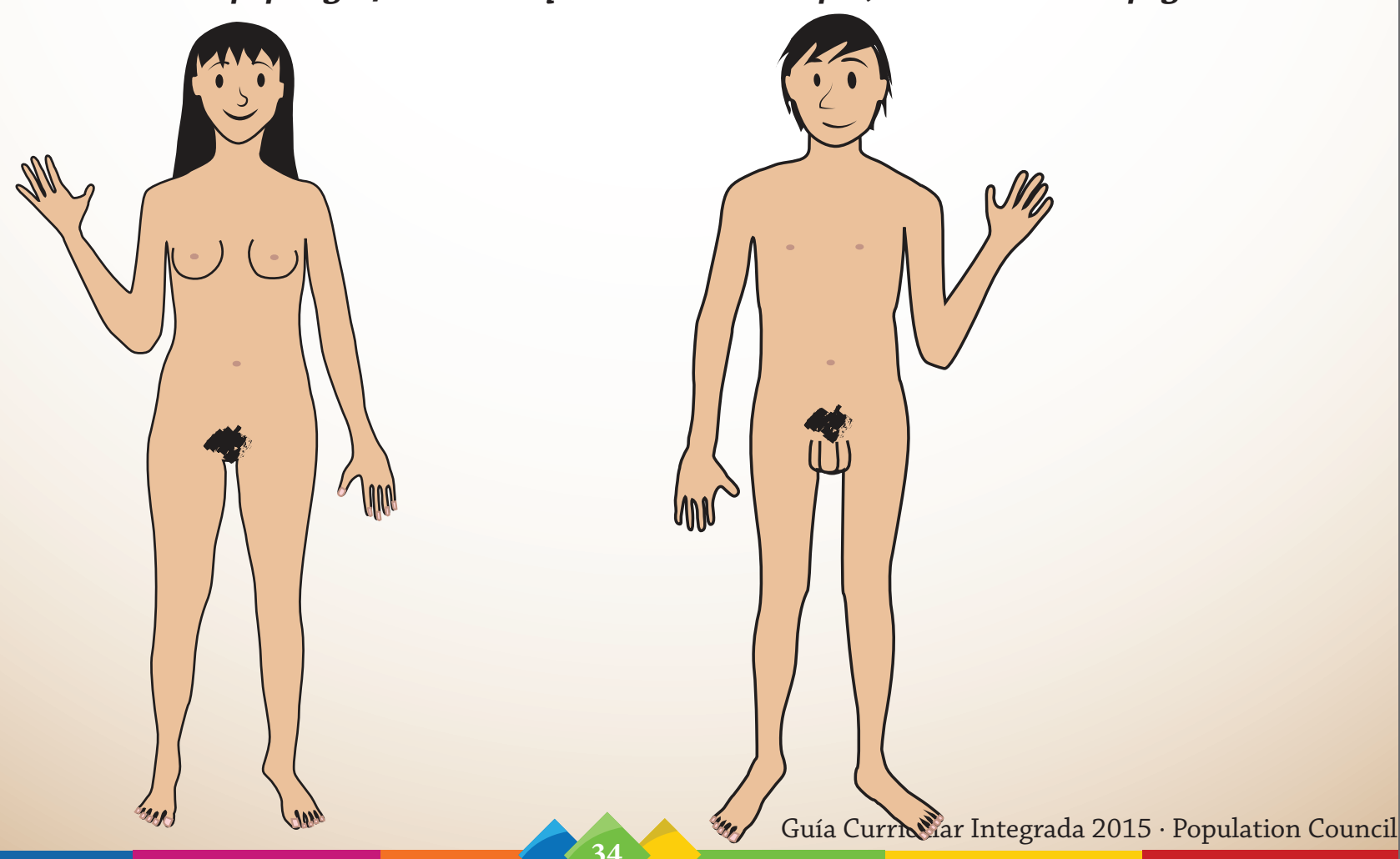


\section{Aplicación para la vida:}

Lea la hoja de información prácticas de higiene importantes a tener durante los días de la menstruación(página \# 133). Luego llene con ellas la guía ¿Es verdad qué? -página \# 131-

Resolviendo todas juntas cada idea.

\section{¿Es verdad qué...?}

\section{Respuesta}

Durante los días de la menstruación no se pueden tener relaciones sexuales.
Falso. Si ella y su pareja están de acuerdo sí pueden tener relaciones sexuales durante la menstruación sin problemas.
Una joven puede embarazarse en la primera relación sexo-genital

La menstruación es una enfermedad

Durante la menstruación tú no debes salir.
Verdadero. En cada relación sexo-genital hay riesgo (peligro) de embarazarse.

Falso. Durante la menstruación realmente no hay nada que la mujer debe dejar de hacer durante estos días. Puede salir a caminar, jugar, hacer ejercicios y comer de todo.

a todas las mujeres.

\section{porque se podría dañar la vagina. \\ Durante la menstruación no debes bañarte}

\section{Durante la menstruación debes cambiarte la} toalla sanitaria por lo menos tres veces al día.
Falso. Durante la menstruación lo más importante es bañarte todos los días. 


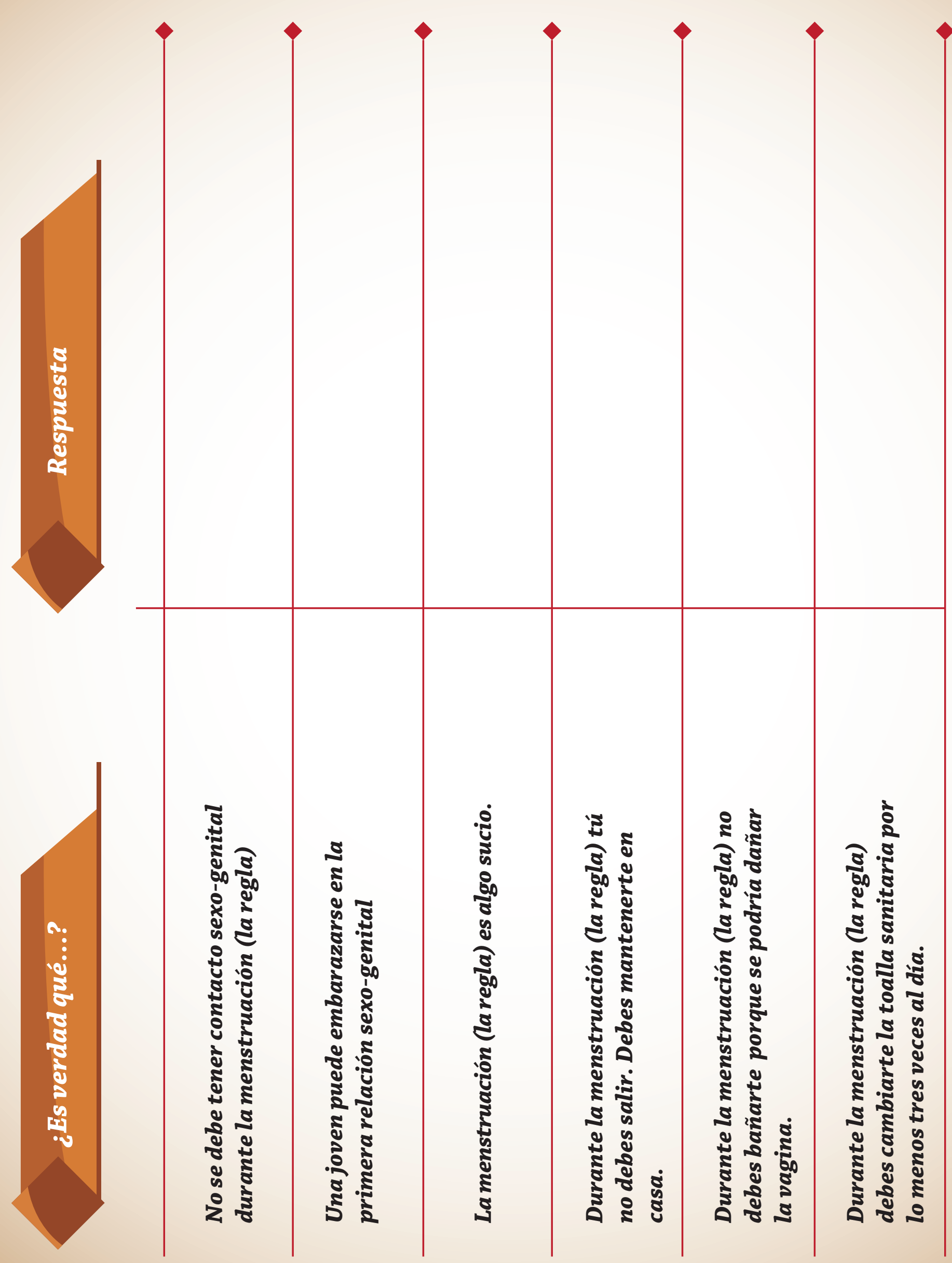




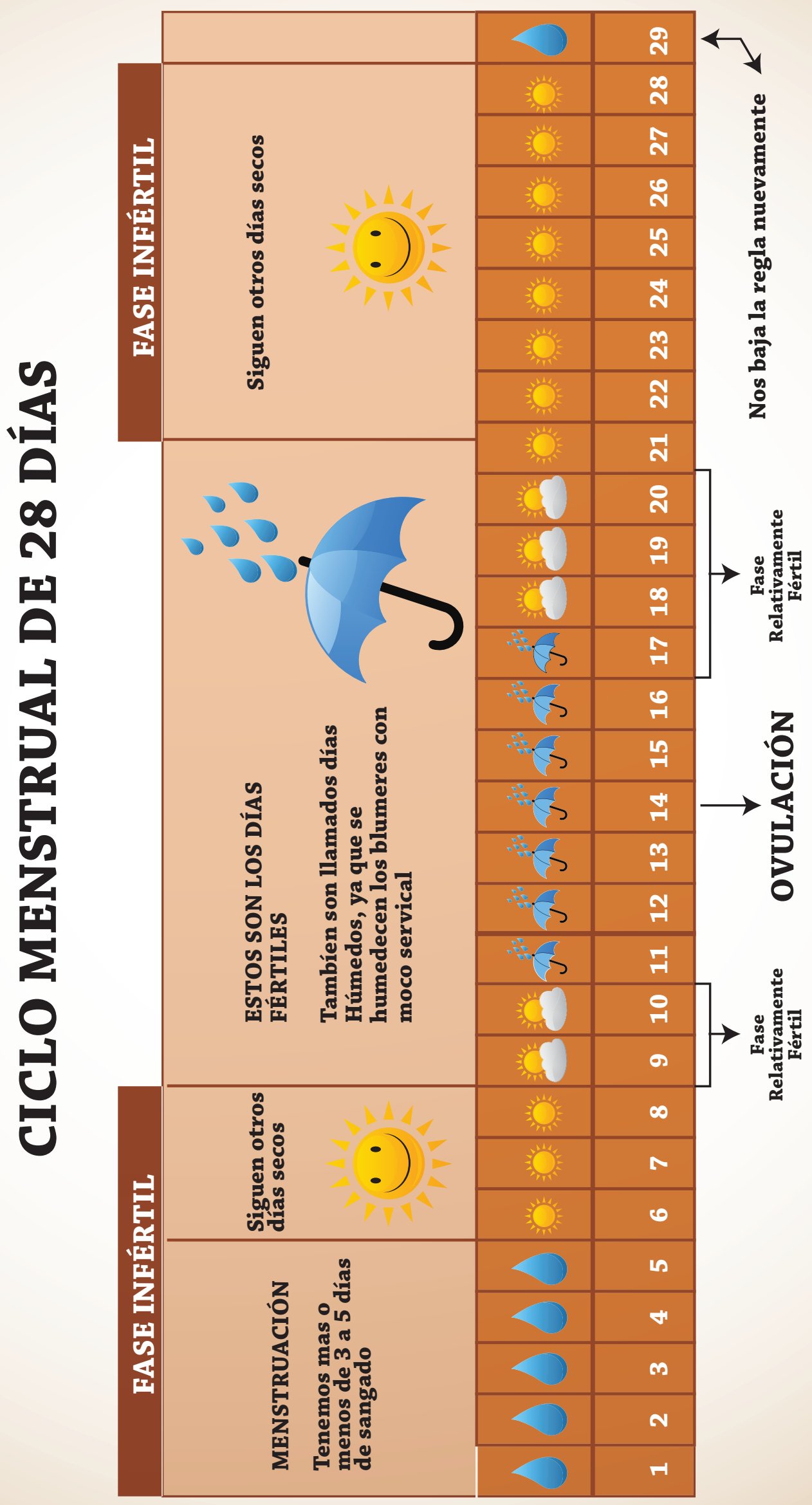




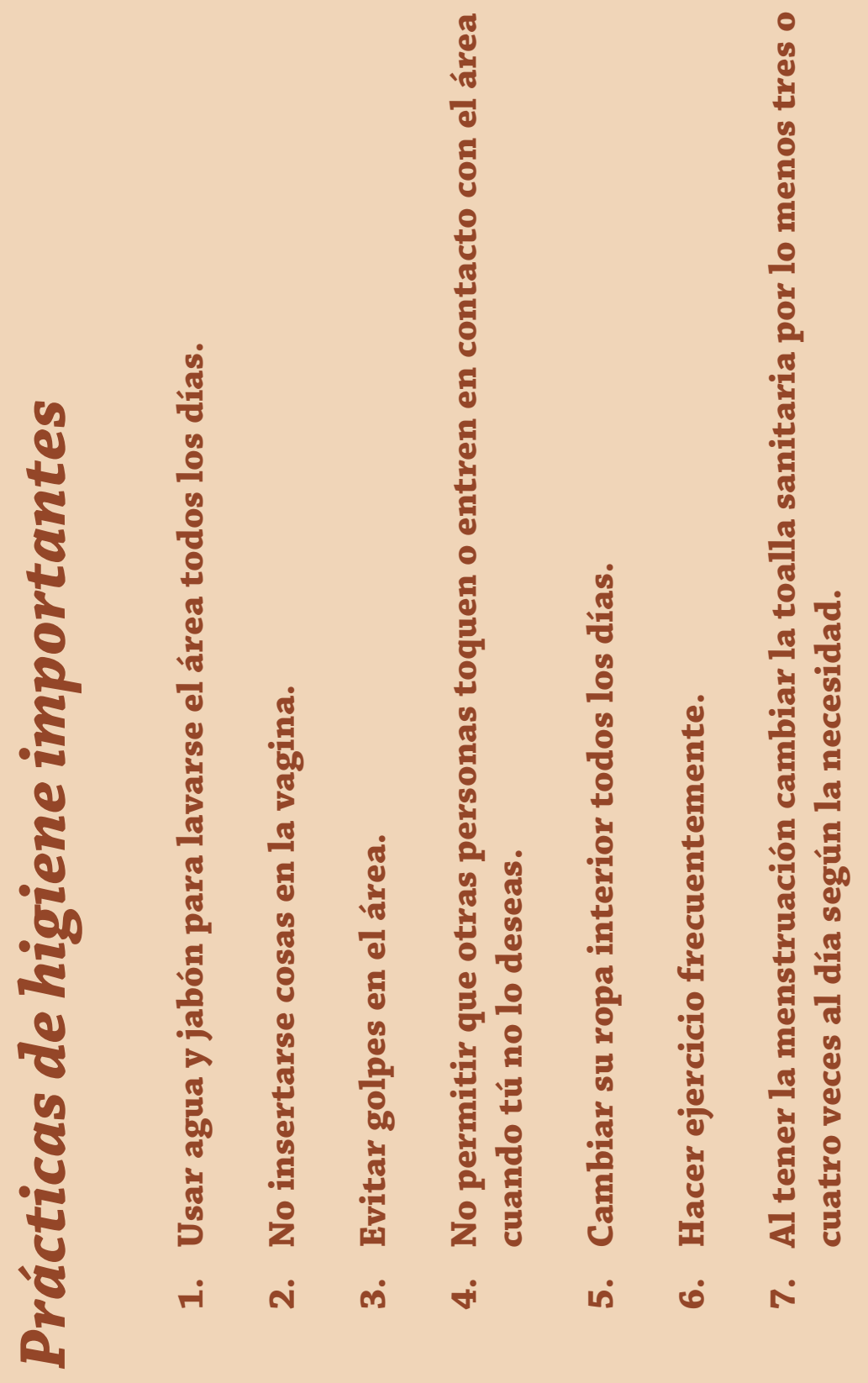




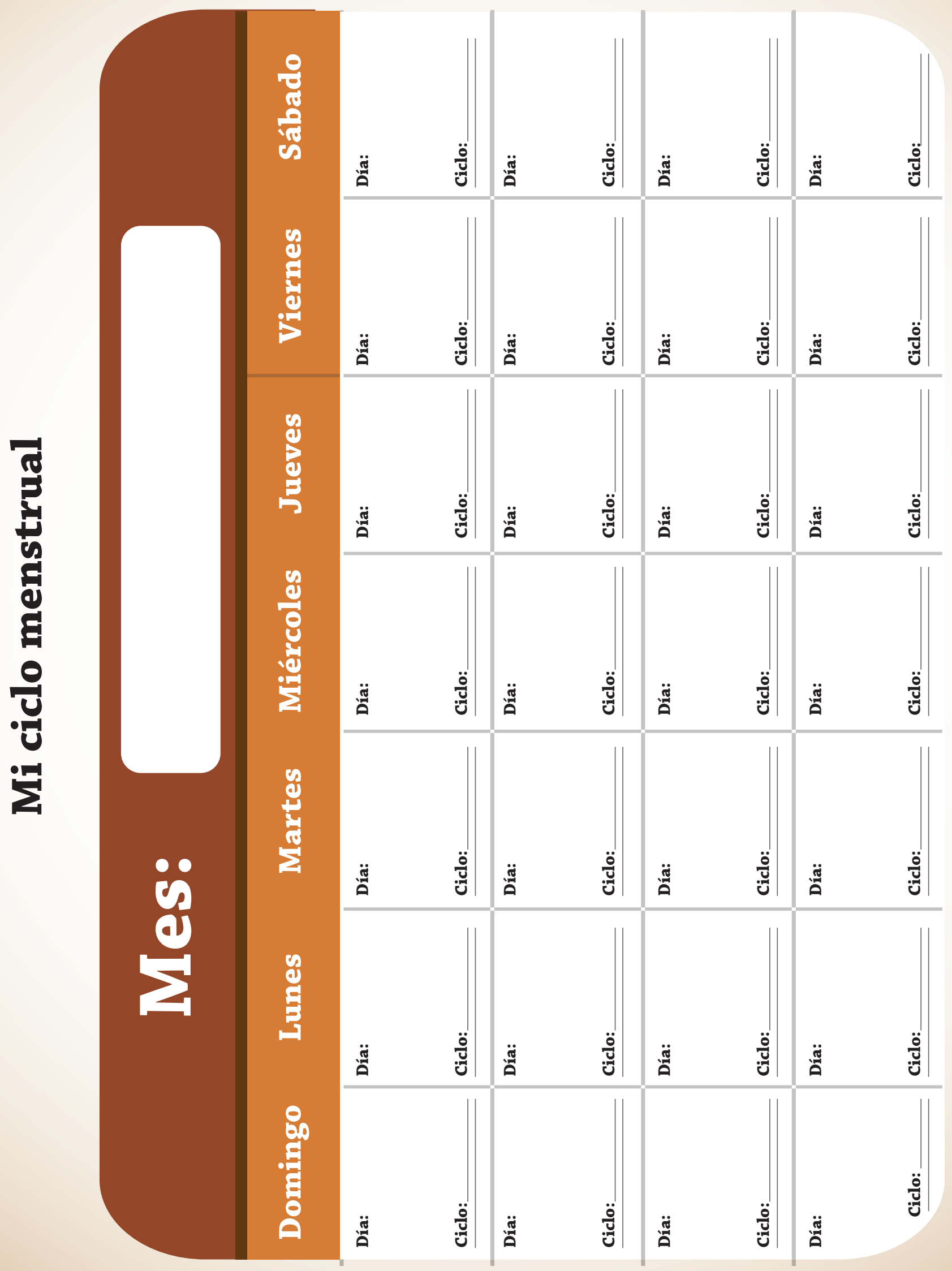




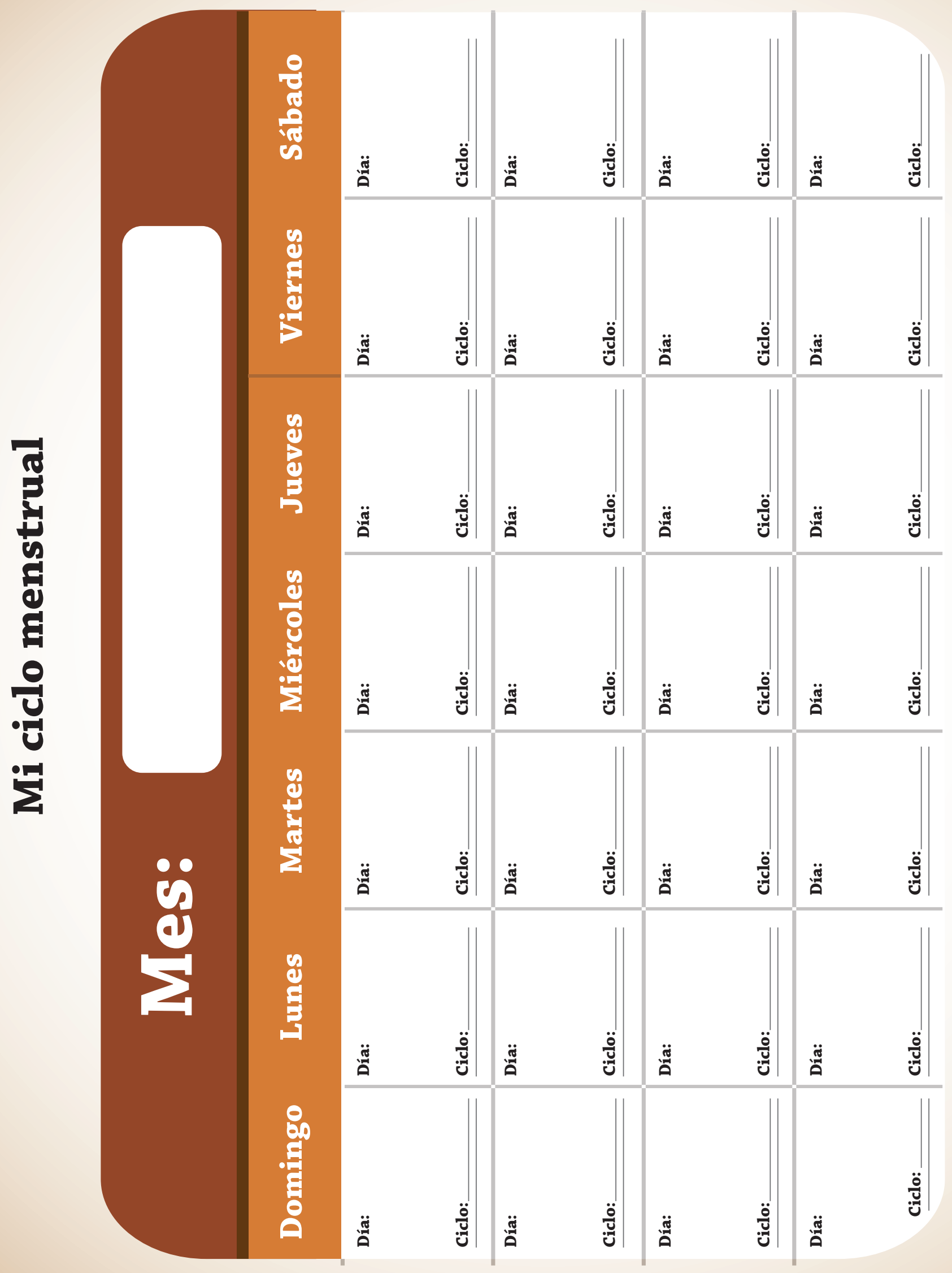




\section{4 ¿Cómo es y cómo nos han enseñado a ser mujer?}

Al finalizar

la sesión las

participantes

habrán...
- Diferenciado sexo de género.

- Identificado los comportamientos de género que han aprendido.

- Entendido que se aprende la conducta de género desde pequeñas.

\section{Conceptos Clave}

Género: características y conductas femeninas o masculinas que se asignan a hombres y mujeres por parte de su comunidad y familia. Sexo: características biológicas de las personas que las diferencian entre hombres y mujeres

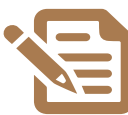

Papelógrafo y marcadores

Muñeca vestida de niño

Muñeca desnuda

Hoja de trabajo

\section{Bienvenida}

Dé la bienvenida a las participantes, confirmando quiénes están presentes o ausentes. Comparta con ellas que el día de hoy van a ver las diferencias entre mujeres y hombres y tratar de entender de dónde vienen estas diferencias.

\section{Introducción al tema:}

Enseñe una muñeca vestida con ropa de niño al grupo y pregunte. Diga que es el bebé del grupo y que le tienen que cuidar. Pídales nombrar al niño y pensar qué trabajo va realizar de grande. Pida que pasen al cartel a dibujar lo que le regalarían en su primer cumpleaños.

Mientras están haciendo eso, diga que parece que es hora de cambiar pañal y pida a una participante que pase al frente a cambiarlo, cuando esté desnudo pregúntele a la participante qué órganos sexuales externos ve. Pregunte a todas si es niña o niño y porqué pensaron que era un niño. Presente un muñeco sin ropa ni pañal y pregunte al grupo: ¿En qué se diferencian las niñas y los niños a esa edad? Pregunte:

\section{¿Qué diferencia a LAS nenas de LOS nenes?}

Escribas las respuestas en un papelógrafo, escribiendo en una columna lo que es de las nenas y en otro lo de los nenes. Puede quedar algo así: 
Nenas:

Vulva

Ropa rosada

Juegan con muñecas

Ayudan en casa

Pelo largo
Nenes:

Pene

Ropa azul y celeste

Juegan con carritos

Van a la Escuela y al campo

Pelo corto

\section{Teorizar y definir:}

Pida que de las diferencias que escribieron identifiquen una por una, si es algo que se nace así o es algo que se aprende y la comunidad le enseña a uno. Marque con una X las cosas que se traen de nacimiento y subraye las cosas que se aprenden o la comunidad las decide.

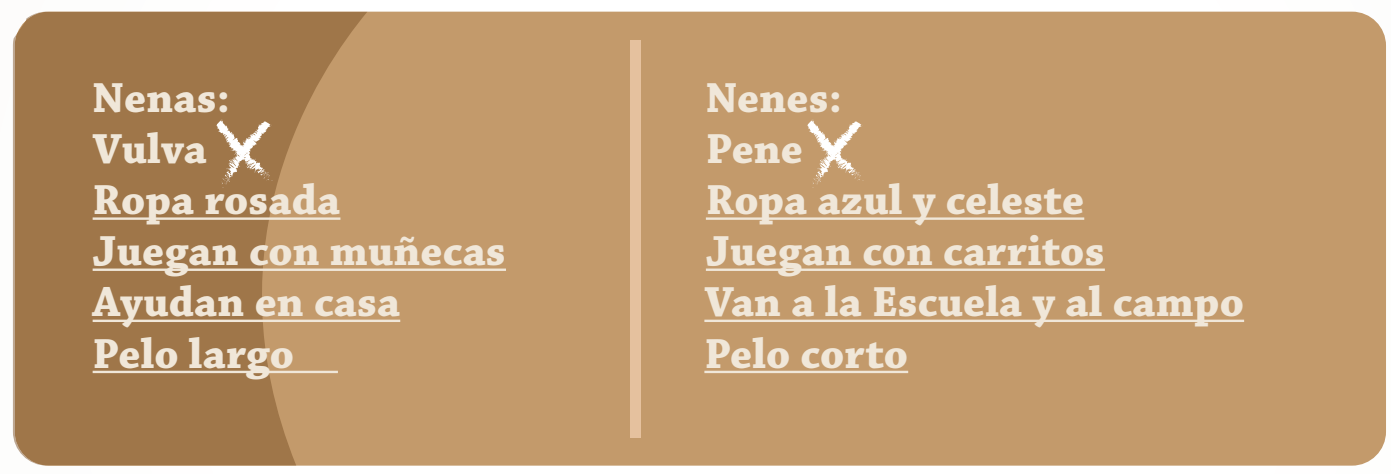

\section{Pregunte:}

¿De dónde se originan la mayoría de diferencias entre niños y niñas?

En lo que se aprende y la comunidad decide.

¿Desde qué edad aprende uno a ser niña o a ser niño?

Desde que nace, a veces antes de nacer ya marcan con los colores y los nombres el ser niño o niña.

Explique a las participantes la diferencia entre sexo y género. Coloque al frente un papelógrafo que dice: La diferencia entre sexo y género, con la siguiente tabla. Mientras revisa cada aspecto va explicando a las participantes y usando ejemplos. 
Diferencias biológicas.

Hombre y Mujer

Lo traemos desde la concepción en el vientre.

No limita a los hombres y las mujeres de desarrollarse y ser felices.

No se puede cambiar.

Decide nuestras tareas en la reproducción biológica.
Diferencias sociales de comportamiento y de costumbre.

\section{Masculino y Femenino}

Lo aprendemos desde que nacemos por nuestra familia, escuela, iglesia, comunidad medios de comunicación etc.

Establece diferencias entre lo masculino y lo femenino que limita la forma de portarse y a veces es violento.

\section{Se puede transformar.}

Decide nuestras tareas en la vida en la casa, en la sociedad etc.

¿Si regresamos a las columnas de las diferencias entre niños y niñas, pueden encontrar algunas que limitan que las niñas se desarrollen, sean libres y salgan adelante felizmente?

Sí, cuando a una niña no se le manda al Instituto porque se va a casar, o cuando se le obliga a casarse, o cuando se le limita a las tareas de la casa y los hijos y no puede tener un trabajo y desarrollarse.

¿Si las características de género son aprendidas y pueden cambiarse; podemos cambiar también estas limitantes para las mujeres?

Sí.

Pídales que se reúnan en parejas y realiceen la hoja de trabajo “Mujeres y Hombres”. En esa hoja deben marcar si la característica que se menciona es dada por el género o por el sexo, escribiendo una $G$ (si es de género) o una $\mathrm{S}$ (si es de sexo) en el espacio en blanco. Luego pensar en cómo afecta esta idea a las mujeres y los hombres. Al finalizar pueden revisar juntas sus respuestas dando oportunidad que una o dos parejas compartan sus respuestas para cada ejemplo.

\section{Aplicación a la vida:}

Las participantes van a evidenciar como su género ha marcado su identidad. Realizando la hoja "Pensando en mi identidad más allá de los roles de género" 


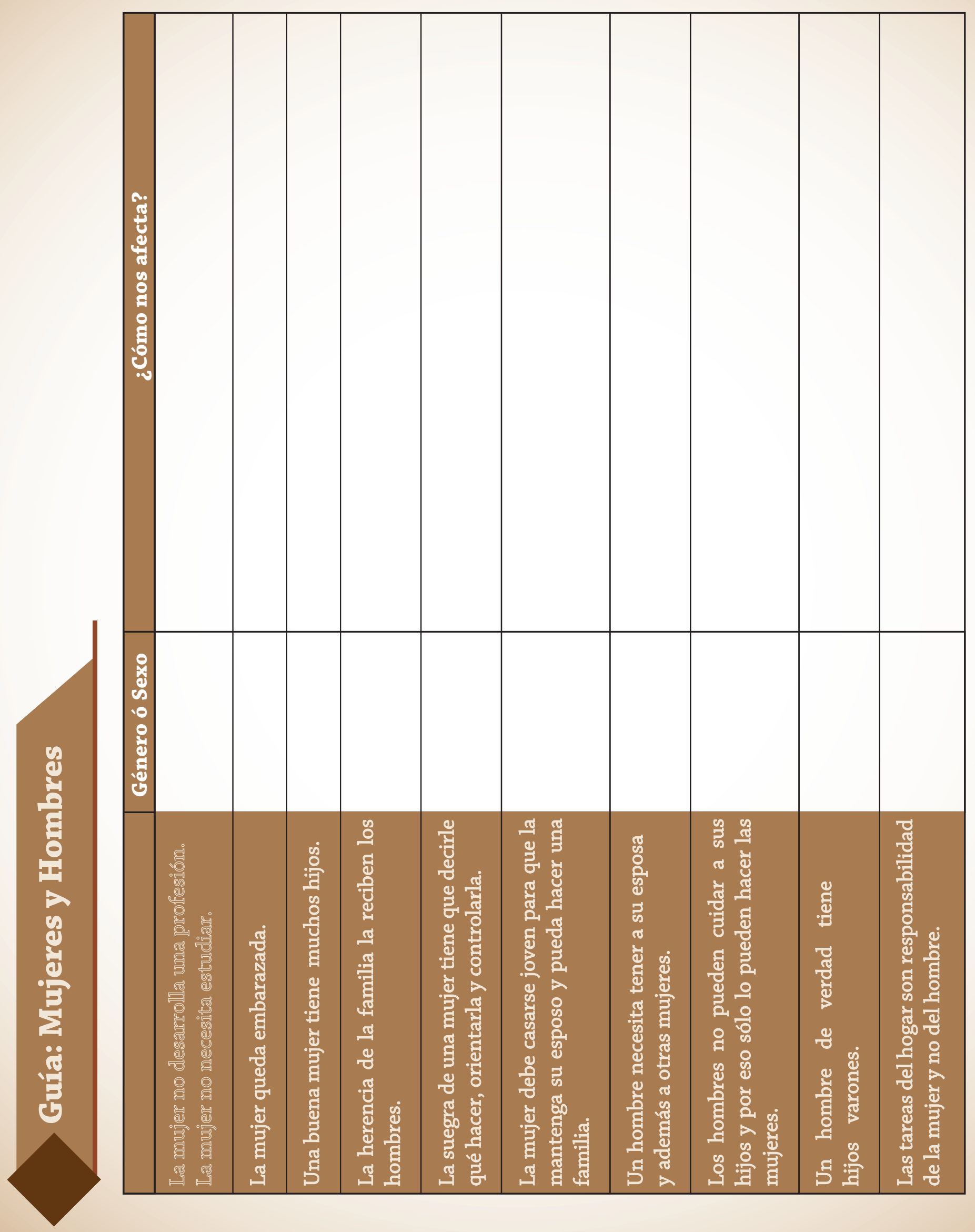




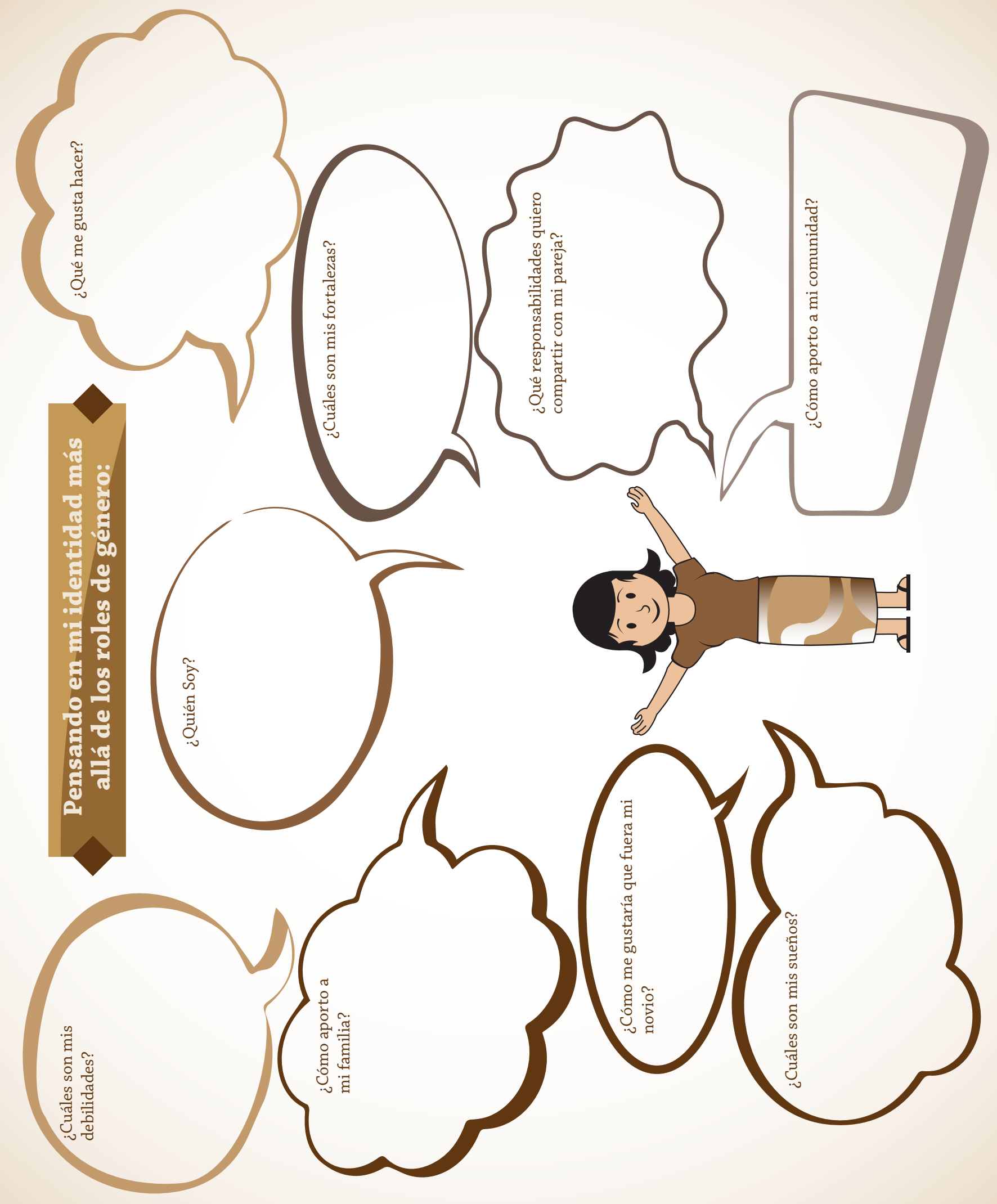


Al finalizar

la sesión las

participantes

habrán...
Identificado los problemas en común que afrontan las mujeres en la sociedad.

Conocido qué es la sororidad.

Planteado tener otro tipo de relación entre mujeres en donde se apoyan, ayudan y aconsejan como propone la sororidad.

\section{Conceptos Clave}

Sororidad: un tipo de relación entre mujeres, basado en la hermandad. Como mujeres reconocemos que compartimos muchos problemas que vienen por la forma en que la comunidad piensa que debe ser nuestro género y nos imponen cosas sin permitir nuestra libertad y derechos al desarrollo. Unidas podemos mejorar la situación para todas, más que si estamos compitiendo.

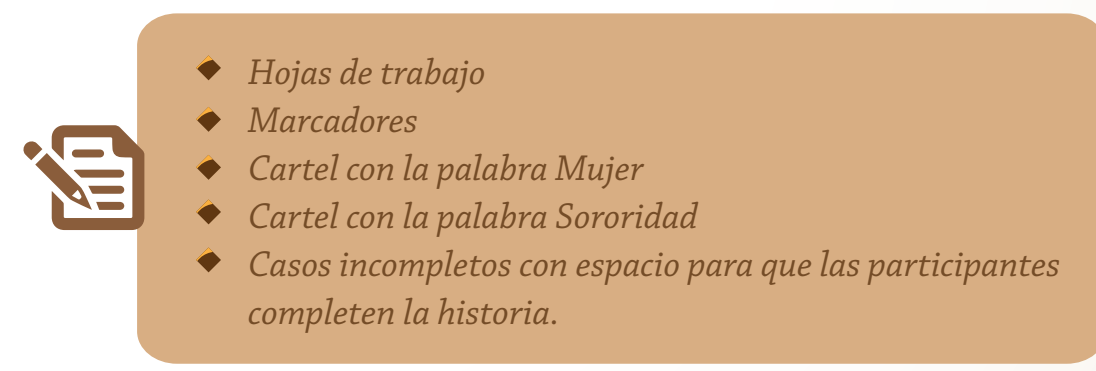

\section{Bienvenida:}

Dé la bienvenida a las participantes, confirmando quiénes están presentes o ausentes. Comparta con ellas que el día de hoy van a platicar sobre la forma en que las mujeres estamos acostumbradas a relacionarnos entre nosotras.

\section{Introducción al tema:}

Forme 5 cinco grupos y entregue a cada grupo un papel con alguno de los siguientes casos que están incompletos. Ellas deben discutir el caso, pensar en qué es lo que pasa en su comunidad en situaciones similares y completar la historia escribiendo lo que la comunidad hace. 


\section{Caso 1}

Una vecina ha empezado a trabajar en una oficina y sale muy arreglada y bonita de su casa. Las vecinas la ven salir asi y entre ellas dicen...

\section{Caso 2}

Una alumna saca 100 en su examen de matemática que tanto le ha costa antes. El maestro le da un abrazo y la felicita. Algunas de sus compañeras que no ganaron el examen la ven y comentan entre ellas que...

\section{Caso 3}

Una niña va camino a la escuela pero está muy cansado por el trabajo en la casa desde la madrugada. Se acerca a comprar un atol y por accidente bota la tinaja con el atol dentro. La vendedora y las otras niñas que están comprando la ven y le dicen:

\section{Caso 4}

Una patoja va caminando en la calle y un muchacho va detrás de ella hablándole. A ella le gusta él y decide parar para saludarlos. Su mamá que la ve de lejos piensa:

Al terminar de escribir el final de los casos. Cada grupo presenta la situación al resto de su grupo. Luego de escuchar todos los casos pregunte a las participantes:

¿Qué nos muestran los casos sobre las relaciones entre mujeres? ¿De dónde hemos aprendido a portarnos así con otras mujeres? ¿Cómo le afecta a la mujer de cada caso la reacción que tiene la comunidad? ¿Si las mujeres nos peleamos entre nosotras, quién sale ganando en casos de violencia? ¿En qué cosas podríamos apoyarnos y ayudarnos?

\section{Teorizar y definir}

\section{Diga a las participantes:}

Tal como una persona nos puede golpear o violar, alguien también puede decirnos cosas que nos hacen sentir mal. Los golpes y la violación dañan nuestro cuerpo, pero escuchar palabras feas dirigidas a nosotras, puede bajar nuestra autoestima y hacernos sentir tan mal que no queremos destacar, ni esforzarnos más por lograr nuestros sueños $y$ metas. Si siempre escuchamos esas cosas empezamos a creerlas aunque no sean verdad. Por ejemplo, si la mamá siempre dice a su hija que es bruta y no vale nada, la niña va a pensar que es bruta y no vale nada. Pero ya sabemos que todas somos especiales e importantes.

Hace algunos años un grupo de mujeres empezaron a pensar que la forma de relacionarse entre las mujeres podría ser diferente ya no competir, criticar y hacer sentir mal a la otra. Vieron que como las mujeres tenemos retos $y$ problemas comunes podríamos más bien ayudar y apoyarnos unas a otras. A esta forma de relacionarnos le llamaron SORORIDAD. En vez de que hubiera muchas mujeres divididas peleando entre ellas, podríamos ser un grupo grande de mujeres que nos apoyamos unas a otras. A veces los chismes son en contra nuestra o bien es a nosotras a las que no están diciendo cosas desagradables también allí es importante creer en nuestro valor $y$ hacernos respetar. 


$$
10
$$




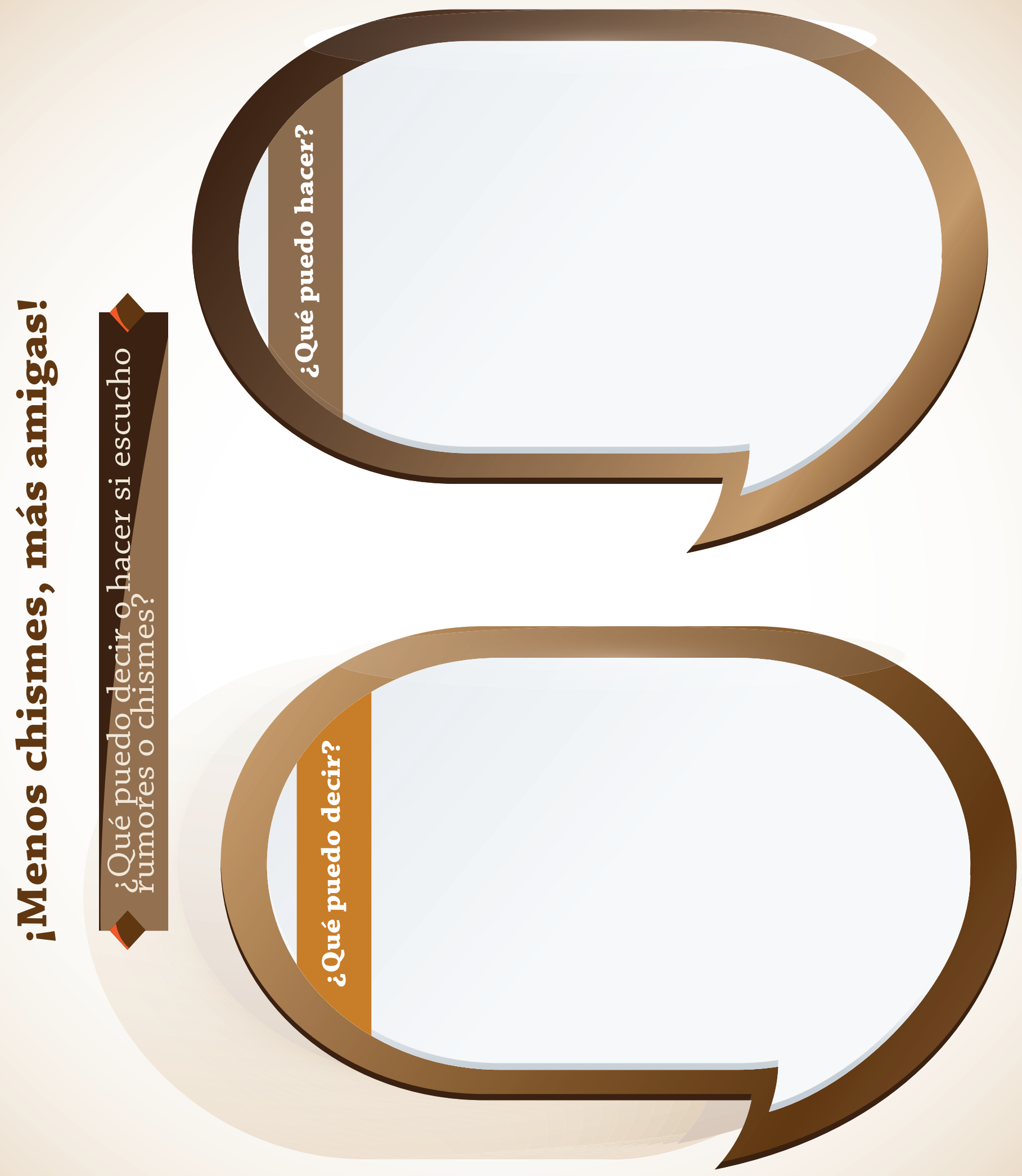




\subsection{Respeto la dignidad cuando me comunico}

Al finalizar

la sesión las

participantes

habrán...
Diferenciado la comunicación agresiva, asertiva y pasiva.

Entendido porqué una buena comunicación es un medio importante para hacer valer y respetar la dignidad propia y de otras personas.

Practicado técnicas que mejoran la comunicación.

\section{Conceptos Clave}

Comunicación: la transmisión de ideas y mensajes entre dos o más personas, por medio de un lenguaje en común.

Asertividad: características de comunicarse de forma afirmativa y clara.

Agresividad: tendencia a actuar o responder violentamente.

Pasividad: característica de quién deja a los demás hacer y no toma liderazgo ni se hace responsable de accionar.

Papelógrafo con las palabras Asertiva, Pasiva y Agresiva

Dibujo de un gallo, un conejo y un gato

Hoja de trabajo

$\checkmark$ Fichas con guiones para las guías de la actividad de las frutas

\section{Bienvenida:}

Dé la bienvenida a las participantes, confirmando quiénes están presentes o ausentes. Empiece la sesión intentando comunicarse con ellas pero sin hablar, por medio de señas. Luego explíqueles que hoy se estará trabajando sobre formas de comunicación.

\section{Introducción del tema:}

Juegue con las participantes. Pida a tres voluntarias que serán las guías de la actividad quienes usarán diferentes formas de comunicarse al dar instrucciones a las compañeras. Aparte por un momento a las tres voluntarias e indíqueles a cada una que va a pedir a sus compañeras que formen grupos de diferentes cantidades diciendo...Quiero canasta con \#XX frutas. Especifique a cada una cómo dará las instrucciones. 
La primera lo hará en calladito, viendo al suelo sin hablar muy recio y con muy pocas palabras sugiérale en una ficha el siguiente guión: "compré tres" "quería comprar cuatro pero solo habían dos entonces fui con otra vendedora y pedí cinco, ella sí tenía”

La segunda lo hará de forma clara, hablando recio viendo a los ojos a las demás compañeras y diciendo exactamente lo que quiere decir, ni más ni menos. Se asegura que las compañaras le escucharan y entendieran y si alguna tuvo duda le vuelve a decir la cantidad. Sugiérale en una ficha el siguiente guión: "Fui al mercado y compré 6 frutas", "Fui al mercado y compré 8 frutas".

La tercera lo hará de forma enojada, gritándoles y con más carácter, les puede hablar rápido y si alguna no entiende le contesta mal y sin gusto. Sugiérale en una ficha el siguiente guión: "Rápido quiero comprar 2 frutas" "Apúrense que compré 9 frutas" "Dije que una fruta era la que quiero comprar".

Al terminar el juego pregunte:

\section{¿Cómo se sintieron durante el juego?}

¿En qué momentos les fue más fácil/difícil armar los grupos que las guías pidieron? ¿En qué se diferenciaba la forma de las guías de hablarles y pedirles las cosas? ¿Cuándo fue más fácil y cuándo fue más difícil seguir las instrucciones de las guías? ¿Quién las hizo sentirse más seguras y tranquilas por su forma de dar las instrucciones?

\section{Teorizar y definir}

Presente un dibujo de un gallo, un conejo y una gata. Pida que entreguen a cada voluntaria el animal que representa la forma en que se comunicó con el grupo. Lea con ellas los conceptos clave y pida que mencionen cuál de las tres formas de comunicarse de sus compañeras es pasiva, cuál es agresiva y cuál es asertiva.

¿Cuándo han tenido la experiencia de comunicarse de cada una de las formas?

¿Cómo se sienten que las provoca expresarse de cada una de las formas?

¿Cuál es la mejor forma para comunicar una idea, un mensaje, una sensación?

¿Cómo era la mejor actitud de las participantes para escuchar lo que las voluntarias pedían?

¿Con qué actitudes de las voluntarias y las participantes se respetaba la dignidad?

¿Qué efecto tiene la forma en que estamos dispuestas a escuchar a los otros en la posibilidad de comunicar y entendernos mejor?

La comunicación tiene dos fases la que habla y la que escucha, cuando escuchamos también estamos dando mensajes a la persona que nos habla. Hay una forma de escuch a activa y una forma de escucha pasiva y las dos tienen efecto sobre las personas que nos están hablando. Observen de forma detallada las siguientes dramatizaciones y la forma en que actúa la persona que escucha y el efecto que tiene sobre la persona que habla.

\section{Aplicación para la vida:}

Pida a cada una que escriba en un papel algo que ha tenido muchas ganas de decir a otra persona pero no se ha atrevido o no ha sabido cómo hacerlo. Una vez todas han escrito su frase, pídales que se reúnan en parejas con alguien a la que le tienen confianza y que le compartan qué es lo que ha querido decir pero no ha sabido cómo. Juntas deben decidir cómo es la mejor forma de decirlo y practicar entre sí. Al finalizar las que quieren pueden compartir con el resto del grupo.

Invite a las participantes a dibujar o escribir como van a hablar con sus padres, amigas, y maestros, en la hoja de trabajo "Diciendo lo que quiero." 


\section{Acróstico de mujeres y sororidad.}

Pegue un cartel que diga "mujeres" y otro que diga "sororidad". Invite a las participantes a hacer juntas un acróstico, en el que a cada letra de la palabra mujer escriban un problema o reto que comparten con las mujeres de su comunidad.

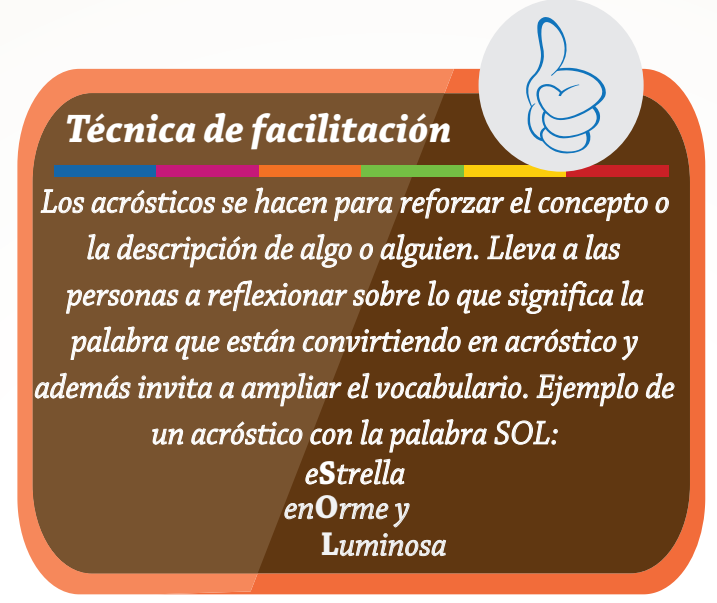

\section{Pregunte a las participantes:}

¿Cuándo se unen las mujeres para resolver sus problemas qué puede pasar?

¿Cómo han visto que unas mujeres apoyan a otras?

¿Qué miedos tenemos las mujeres para afrontar los problemas?

¿Qué podemos hacer para ser mujeres con relación sórica, ayudar, apoyar y fortalecernos?

Repita el ejercicio de acróstico ahora con la palabra sororidad. Pida a las participantes que escribar para cada letra de la palabra una acción que puedan realizar en la que se apoyen unas a otras y cómo actuar cuando se encuentran con un chisme de otra mujer de la comunidad.

\section{Aplicación a la vida:}

Pida a las participantes reunirse en los grupos del inicio y escribir otro final para el caso que les tocó uno en el que las mujeres se apoyen entre sí y lo presentan al resto.

Trabajan la hoja de trabajo "Menos chismes, más amigas" y la hoja "Si alguien me dice algo que me hace sentir mal". 


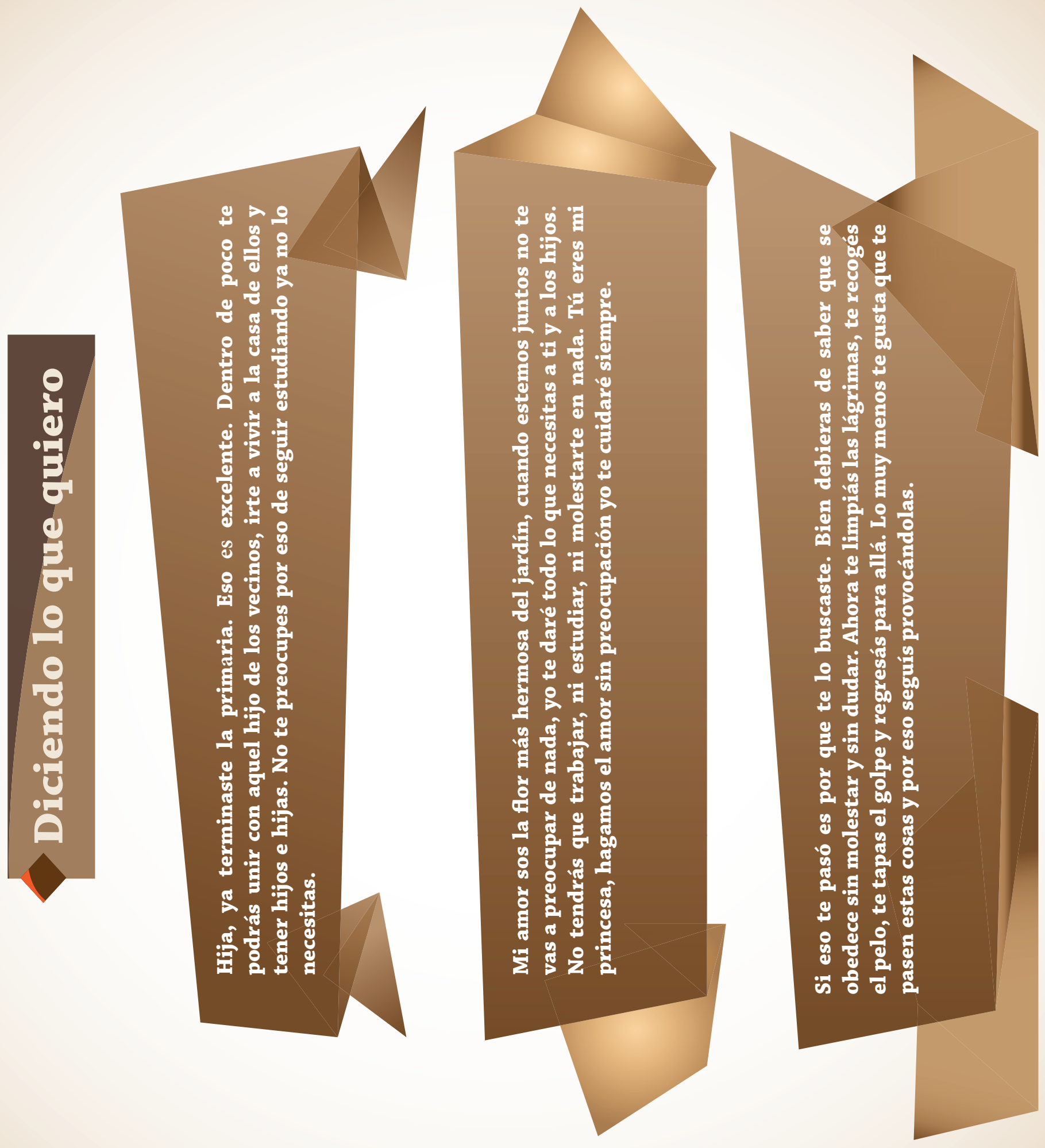




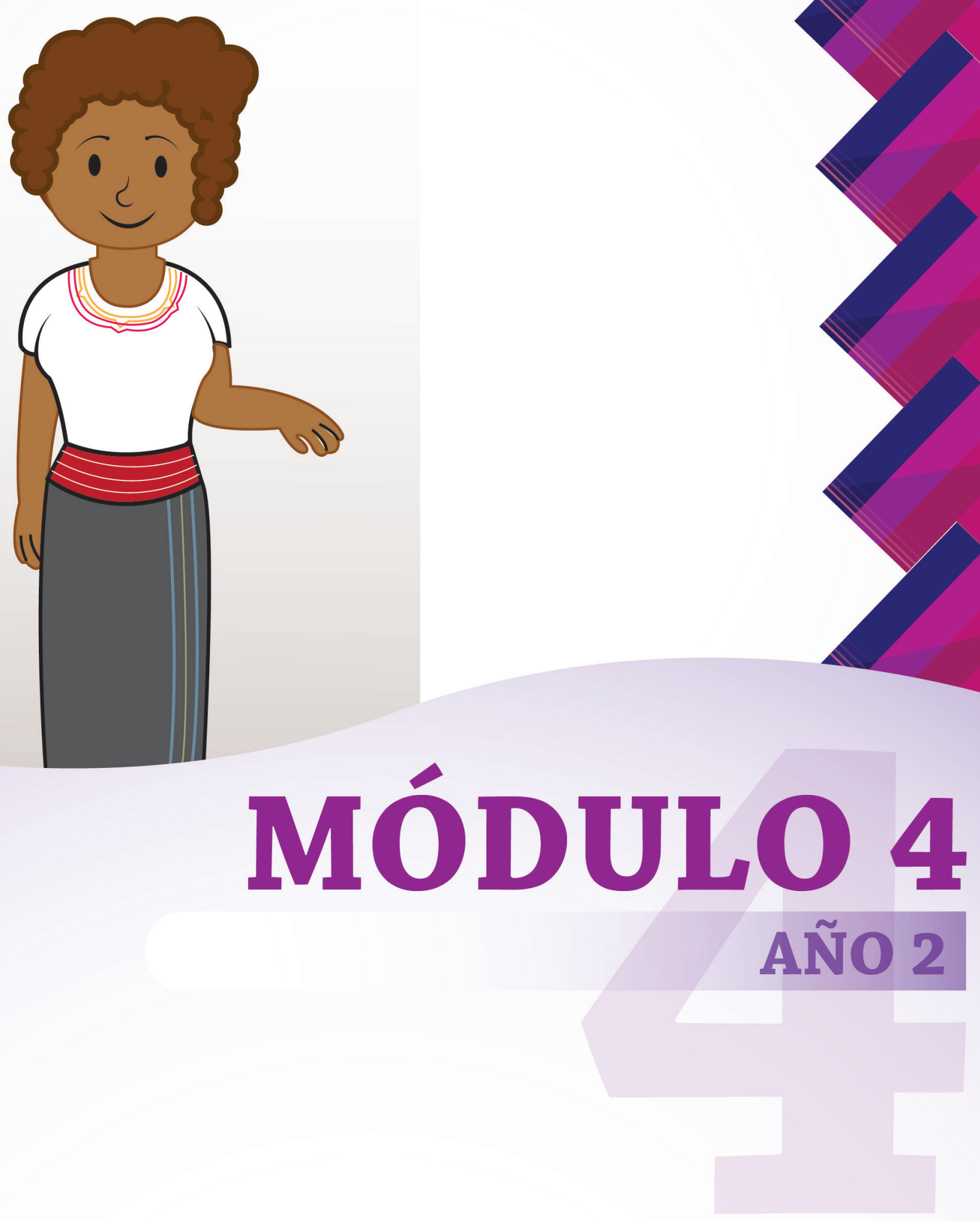

Guía Curricular Integrada 2015 - Population Council 


\section{Créditos}

- Autoras:

María Cecilia Garcés de Marcilla/Especialista en Educación

Paola Broll / Oficial del Programa

- Revisión: Alejandra Munguía/ Coordinador de Campo

- Diagramación:Isaí de la Cruz

- Equipo Population Council 2015:

$\checkmark$ Directora de Programas: Alejandra Colom

- Supervisor de Monitoreo y Evaluación y oficial de Programa: Ángel del Valle

- Administradora: Ana Lucía Rodríguez

- Mentoras: Elizabeth Vásquez, Claudia Macz, Sonia Chó, Patricia Alva, Maribel Gutiérrez, Fabiola Colop y Rosa Güit

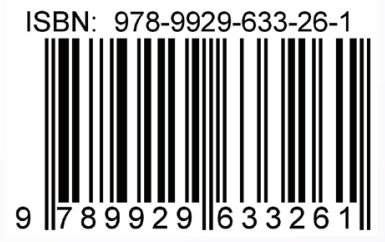




\section{AÑ̃ 2}

\section{Módulo IV}

En esta fase propóngase el reto de mantener la asistencia de las participantes. En este segundo año de formación empieza a trabajarse también el área de proyección comunitaria, pues se espera que lo que han recibido y trabajado las participantes les permita empezar a pensar en proyectos y actividades específicas que ella pueden desarrollar para contribuir al desarrollo del lugar en donde viven. .

\section{Grupo de 8 a 12}

4.1 Abriendo Oportunidades: ¿Cuáles son los espacios seguros en mi comunidad?

4.2 Salud: No es lo mismo comer que alimentarse

4.3 Salud sexual y reproductiva: Puedo proteger mi cuerpo

4.4 Salud sexual y reproductiva: Embarazo, decisión y planificación

4.5 Fortalecimiento personal: Comunicación asertiva cuando me comunico

\section{Grupo de 13 a 17}

4.1 Abriendo Oportunidades: Construyo espacios seguros en mi comunidad

\subsection{Salud: Nutrición}

4.3 Salud sexual y reproductiva: Fertilidad, fecundación y embarazo

4.4 Salud sexual y reproductiva: Derechos sexuales y reproductivos

4.5 Género: Somos muchas y diversas trabajando unidas 
Al finalizar lai Identificado qué lugares pueden ser espacios seguros para las mujeres de su comunidad.

Sesión las · Nombrado a las personas con las que comparten los espacios seguros y reconocen que es una red de confianza y apoyo. participantes Explicado cómo el género incide en la seguridad y el acceso a espacios de la comunidad.

habrán... · Diseñado una estrategia de protección personal.

\section{Conceptos Clave}

Seguridad Ciudadana: Condiciones que protegen y resguardan el bienestar integral de las mujeres y hombres de una comunidad. Esta contempla el respeto a los derechos humanos y la participación de la ciudadanía en las decisiones que se toman.

Red comunitaria de confianza: Relaciones con otras mujeres y hombres de la comunidad con quienes podemos buscar ayuda y formar espacios seguros para nosotras y otras personas.

Medidas preventivas: Acciones que se realizan ante un riesgo, para evitar que el mismo suceda.
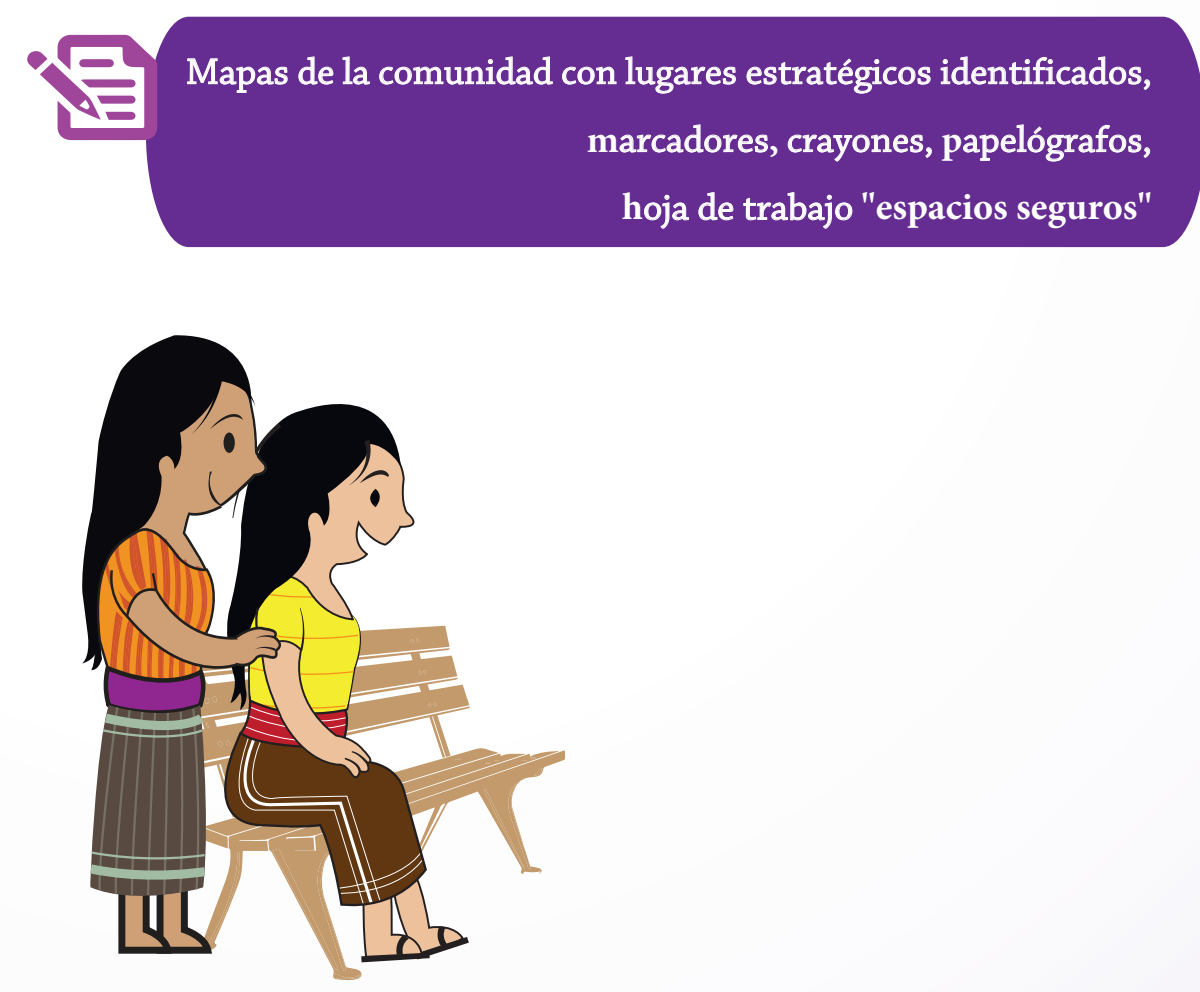


\section{Bienvenida:}

Dé la bienvenida a las participantes, confirmando quiénes están presentes o ausentes. Muéstreles su gran alegría de verlas de nuevo y seguir trabajando en las sesiones de Abriendo Oportunidades. Adelante algunos de los temas más interesantes y de las actividades más alegres que se estarán tratando durante este año. Comparta con ellas que el día de hoy estarán platicando sobre su comunidad y cómo se sienten dentro de ella, ahora que ya tienen un año de ser parte de una red de amigas con un espacio seguro.

Técnica de facilitación

Empiece por jugar con ellas dando tiempo a que se presenten por su nombre, pida que describan cómo se siente cuando están en el espacio seguro, pero comparándose con un animalito de la comunidad.

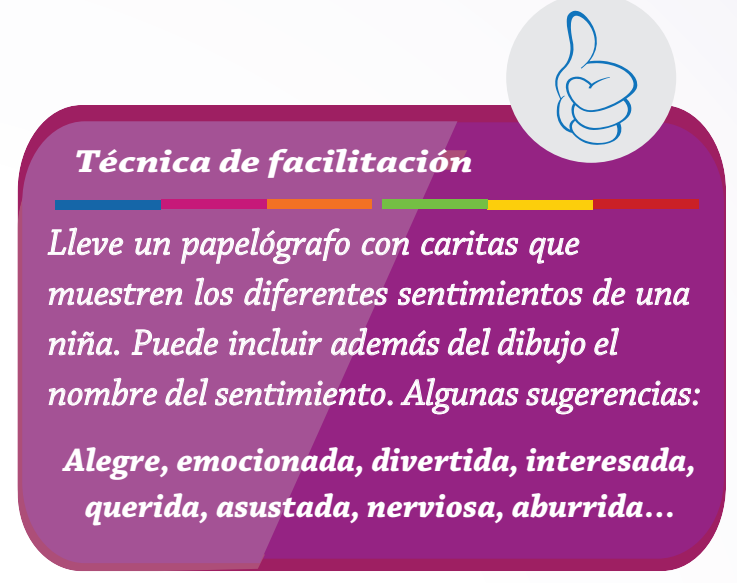

\section{Introducción al tema:}

Coloque un papelógrafo gigante en el suelo, dibuje en él un salón vacío, coloque también muchos crayones a la mano de las niñas. Diga a las participantes que ese es un lugar que es seguro de su comunidad y que está vacío para que ellas todas juntas lo llenen de todas las cosas que lo hacen ser un espacio seguro. Dígales que tienen cinco minutos para completar el dibujo, pensando qué hay dentro de él, quiénes se reúnen, como se tratan, qué hacen, cómo se sienten etc. Al terminar cuelgue el papelógrafo en la pared para que todas lo vean y hagan una lista de todas las características que tiene un espacio seguro. Escriba las características que le digan en un papelógrafo y destaque las que tienen que ver con la forma de relacionarse y ayudarse dentro de él.

\section{Teorizar y definir:}

\section{Trabajarán en grupos para identificar los espacios seguros/inseguros para mujeres y hombres. Explique que} van a hacer el mapa de las niñas. Entregue un mapa de la comunidad a cada grupo. Pida que dibujen una carita feliz en los lugares que sienten más seguras y más cómodas. Permita que trabajen en sus grupos durante 10 mins. Luego solicite que peguen todos al frente a manera de que sean visibles para todo el grupo, invite a las participantes a ver el cartel de los demás grupos.

Guía al grupo en discusión, apuntando las ideas principales sobre los lugares seguros para mujeres en el pizarrón.
E

Técnica de facilitación

Sel mapa incluya:

Milpas altas $y$ cerros

Pnderos y carreteras

Mercado

glesias

Escuela

alón municipal, Salón de convergencia

Biblioteca,

Eugar de juegos

Locales comerciales

Calles de noche, Carretera

Cantinas

Municipalidad/alcaldía

Terminal

Río 
Pregunte:

¿Qué lugares son seguros para mujeres?

Casa, escuela, abriendo oportunidades

¿Qué actividades se facilitan para las mujeres por los lugares que son seguros para ellas?

Actividades domésticas, estudiar y jugar

¿Qué lugares no son seguros para mujeres?

Calle, mercado, municipalidad

¿De qué forma los espacios no seguros dificultan la participación, el liderazgo, los estudios y el trabajo fuera de casa para las mujeres?

Es difícil que hagan cosas fuera del hogar, por el riesgo que corren en estos lugares

¿A qué lugares tendrían que poder llegar las mujeres para ser activas en su participación, liderazgo, desarrollo etc.?

\section{Centros de convergencia, mercado, municipalidad, transporte}

\section{Diga a las participantes:}

Estos son los lugares que les gustaría que fueran seguros en la comunidad para el bien de todas las niñas y niños. El que un lugar sea un espacio seguro depende no sólo de dónde está y con qué está hecho, sino que también depende de las personas que están en ese lugar y la forma en que nos tratan y cómo nos relacionamos con ellas. A veces un espacio seguro puede ser seguro por ratos y en otros ratos dejar de ser seguro, dependiendo de quién esté alli y qué propósitos tiene. Regresen a sus grupos y escriban con qué personas de la comunidad pueden trabajar en equipo para que los espacios no seguros para mujeres sean seguros.

\section{Aplicación a la vida:}

Entregue a las participantes la hoja de trabajo "Los Espacios seguros". Diga a las participantes que deben pensar en dónde pasan tiempo, puede ser en su casa, la escuela, con el grupo de Abriendo Oportunidades, la iglesia, o en las casas de sus amigas. De estos lugares ellas deben indicar: qué tanto consideran que es un espacio seguro, marcando una estrella si el espacio no es seguro, dos estrellas si a veces es y otras no es seguro, y tres estrellas si siempre es seguro. Para cada lugar pueden escribir qué podría hacerse en ese espacio para convertirlo en uno seguro y con qué personas podrían trabajar para eso. Al finalizar se abre la oportunidad de que compartan sus respuestas de forma voluntaria entre ellas.

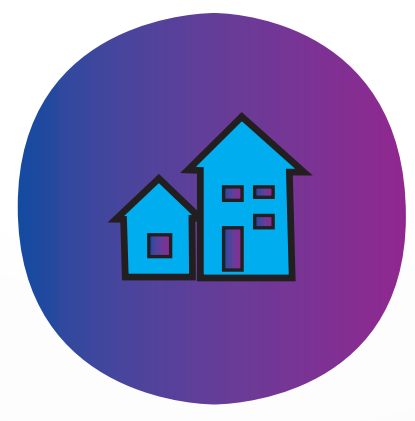



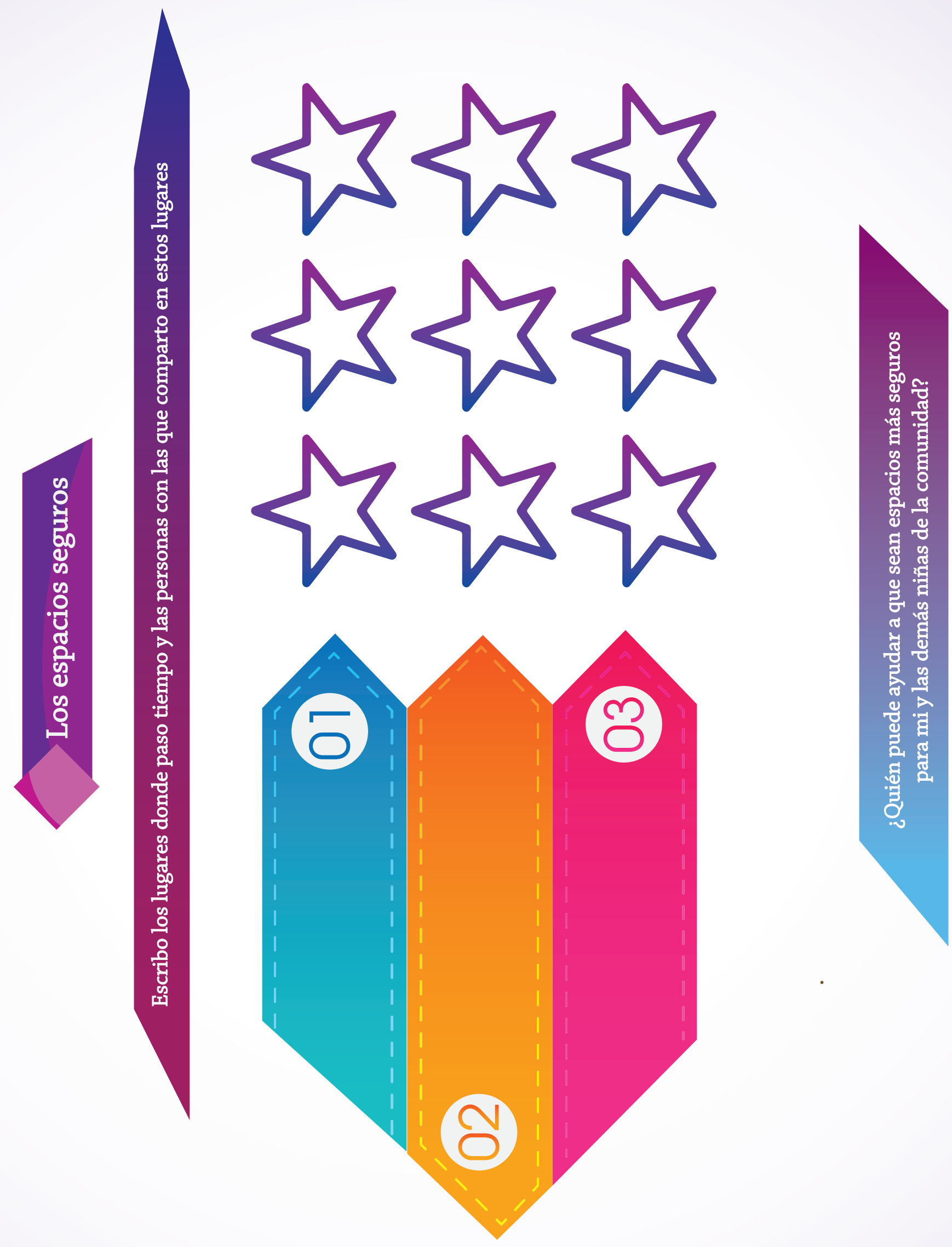


\section{2 horas}
Al finalizar la
* Las participantes han aprendido prácticas de la buena nutrición.
Sesión las
* Las participantes conocen síntomas, signos y efectos de la desnutrición.
participantes
habrán...
* Las participantes conocen estrategias para prevenir la desnutrición según la olla alimentaria.

\section{Conceptos Clave}

Alimentos nutritivos: son los que aportan una importante cantidad de vitaminas, minerales y proteínas que además de hacernos sentir satisfechas y sin hambre aportan al bienestar de nuestro cuerpo y a nuestra salud.

Olla alimentaria para Guatemala: es un esquema de qué alimentos son los más recomendables y qué tan seguido se debiera comer cada tipo de alimento, hecha especialmente para las poblaciones alimentos de Guatemala.

\section{Bienvenida:}

Papelógrafos · Papeles con el nombre de un alimento de la olla nutricional (uno para cada participante) - Hoja de lectura Alimentación Nutritiva para Guatemala Hoja de trabajo "Jardín nutritivo" · Marcadores

Dé la bienvenida a las participantes, confirmando quiénes están presentes o ausentes, recuérdeles que es importante que sigan llegando para seguir aprendiendo sobre los temas que están aprendiendo. Juegue con ellas "Simona Come". Explique que usted dirá el nombre de alimentos que Simona ha comido hoy y si es un alimento que fortalece brincarán pero si es uno que provoca debilidad se tirarán al suelo como desmayadas. Después de hacer usted dos rondas, pida que ellas hagan las siguientes diez rondas y escriba en un papelógrafo los alimentos que van diciendo.

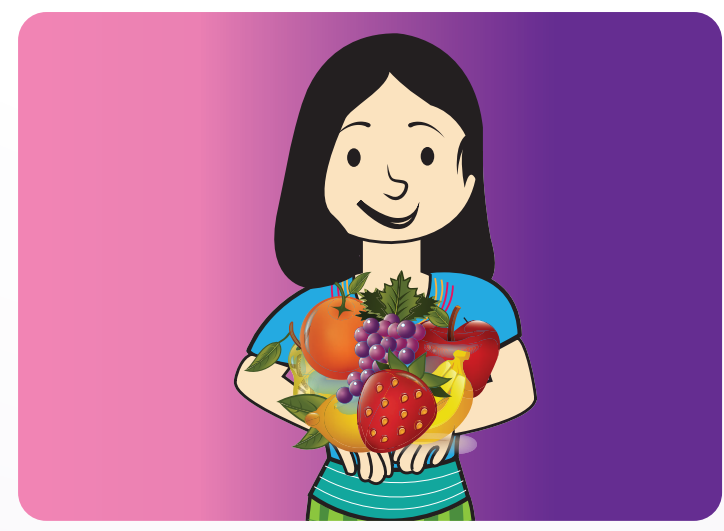




\section{Introducción al tema:}

Al terminar todas, dígales que juntas van a identificar ¿cuáles cosas en la lista son buenas para la nutrición y cuáles no tanto?. Vaya alimento por alimento, haciendo un cheque si es nutritivo y una $\mathrm{X}$ si no lo es.

\section{Teorizar y definir:}

Para dar a conocer los nutrientes y alimentos que se deben consumir según la Olla nutricional diga:

Nuestra salud y nuestros ánimos para la vida dependen de lo que comemos y la forma en que comemos. Comer no es lo mismo que nutrirse. Cada cuerpo necesita cierto tipo de nutrientes para estar en buenas condiciones y nutrirse de diferentes alimentos para aprovechar toda la riqueza que tiene la tierra.

Entregue a cada una la hoja de lectura "Alimentación nutritiva en Guatemala", leyendo toda la información que contiene por medio de la dinámica "El cartel de los alimentos con el grupo". Muestre un cartel grande de la olla nutricional para Guatemala, pida que vayan nombrando los alimentos que ven en cada espacio de la olla y con qué frecuencia dice que deben consumir esos alimentos (que revisen su hoja de lectura). Pida a todas que pasen a circular qué alimentos comieron ayer. Si no están en el cartel lo pueden dibujar en el área de la olla que corresponda.

\section{Aplicación a la vida:}

Al haber pasado todas, pregunte:

Por qué es importante que las mujeres conozcan para qué sirven los diferentes alimentos? ¿Por qué es importante que las mujeres combinen muchos alimentos diferentes en su dieta? $¿ Q$ ¿é aportan las sopas instantáneas, los tortrix y las gaseosas a la olla nutricional? ¿Con qué otras cosas más baratas podríamos sustituir estos alimentos?

Entregue la hoja de trabajo "Un jardín nutritivo" en la que deben dibujar ¿qué plantas y animales podría tener en su jardín para acceder a una alimentación sana y nutritiva'? 


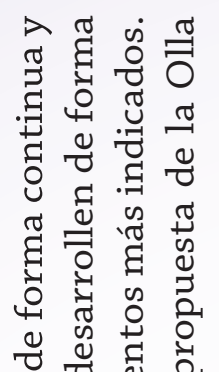

ए ह

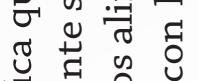

幽 을

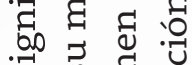

का का द्व

党 용

ชู่

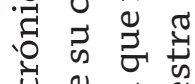

पे $\approx$ व

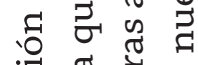

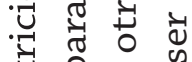

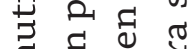

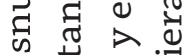

ช के के है

ه

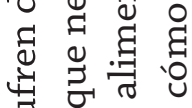

के के चै

䒕艺范

द्वृ ⿷匚⿱

苛䨌先

ปู

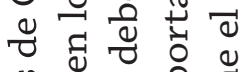

\& छ \& :

苟 0 ○

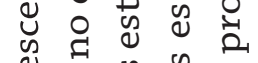

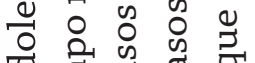

चु क्ष

$\lambda$.

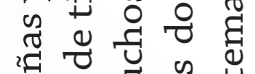

范 \&

ช

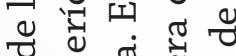

- 2.

t 0 o

สี

น तै 药

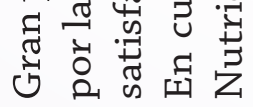

है
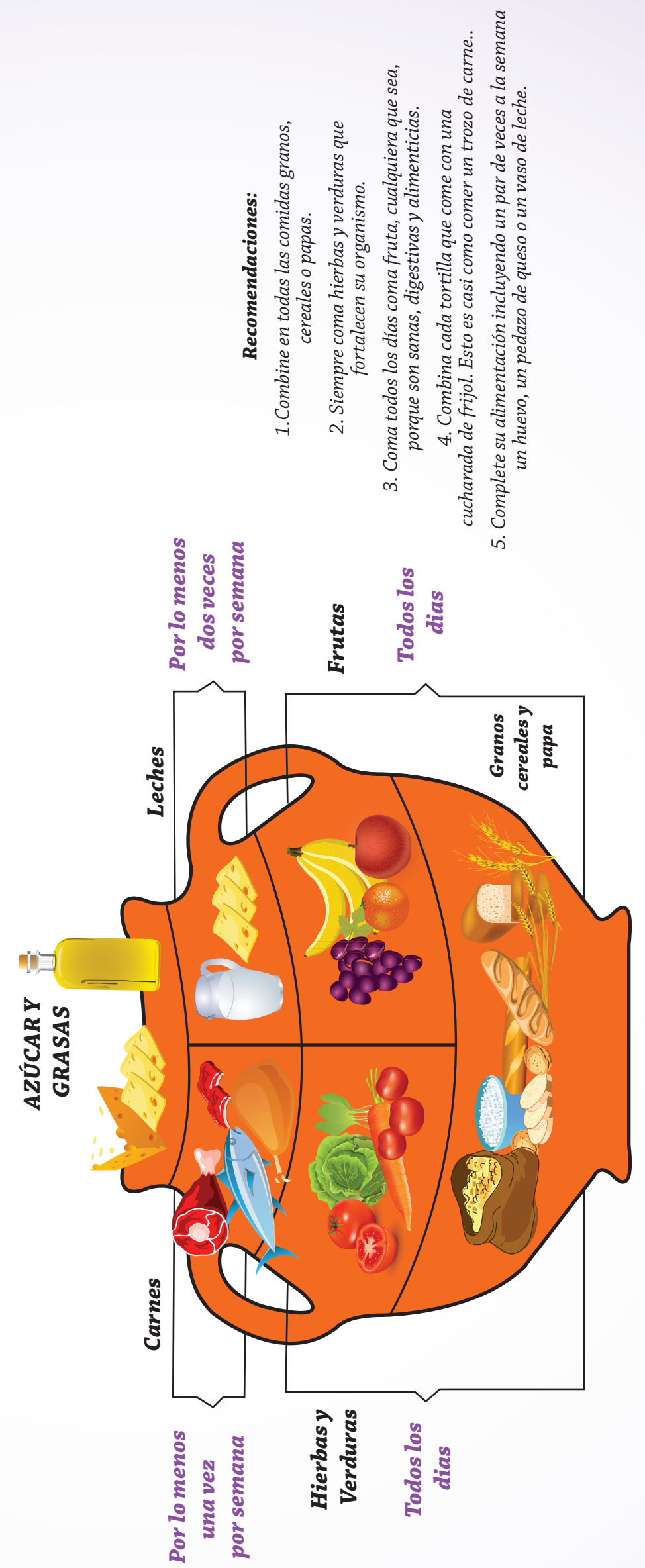


\section{Jardín Nutritivo}

Dibuja como sería un jardín nutritivo según las recomendaciones de la Olla Nutricional. ¿Qué plantas hay en tu comunidad que puedes incluir?¿Qué animales podrías tener también?

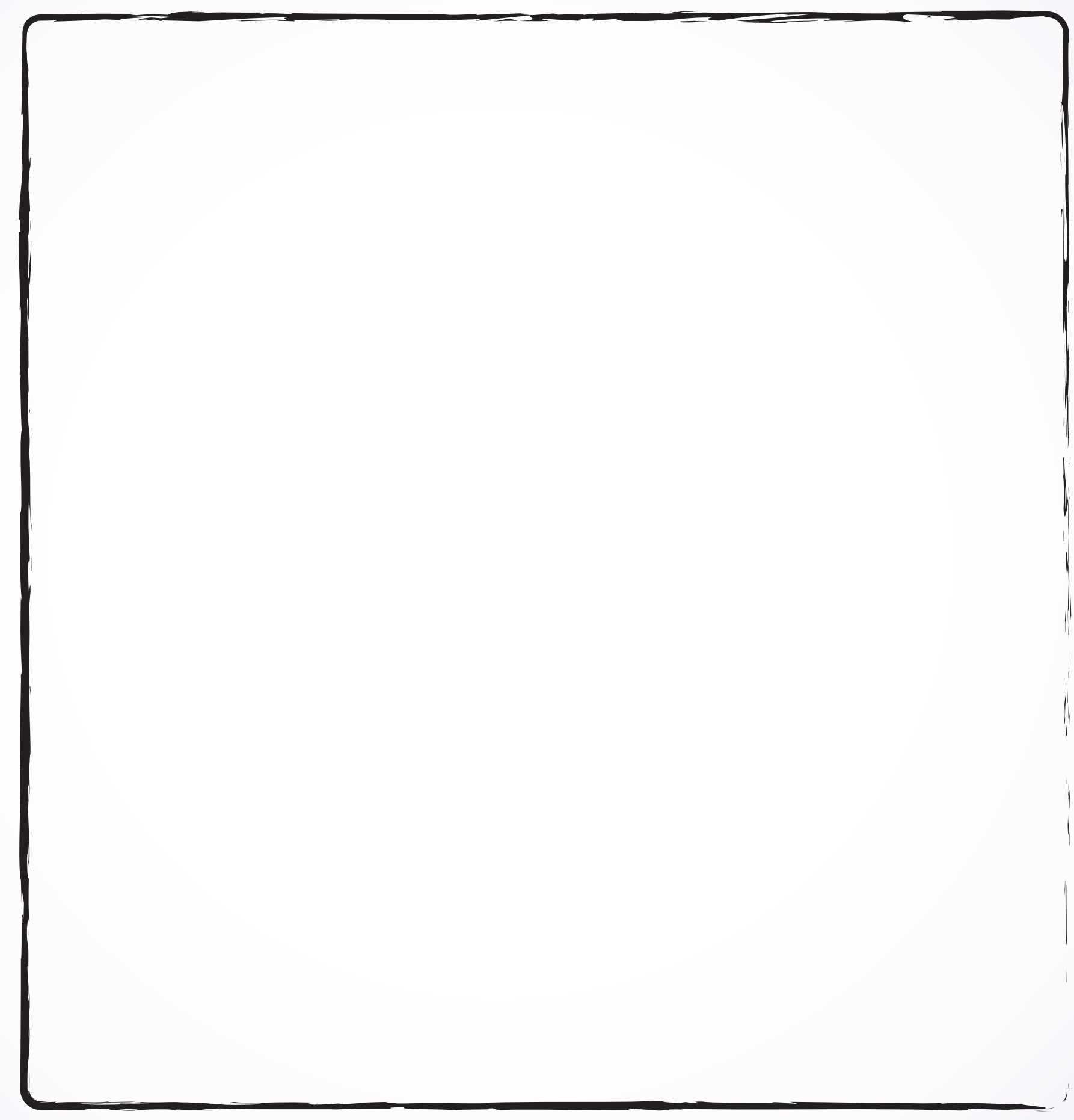


Al finalizar la Sesión las participantes habrán...
- Reconocido que proteger y cuidar su cuerpo es un derecho.

- Identificado acciones que ponen en riesgo el bienestar de su cuerpo y dignidad.

- Nombran a personas que las pueden ayudar.

\section{Conceptos Clave}

Derechos sexuales y reproductivos: conjunto de derechos destinados a proteger la salud sexual y reproductiva de mujeres y hombres de todas las edades.

\section{Bienvenida:}

Dé la bienvenida a las participantes, confirmando quiénes están presentes o ausentes y marcando la asistencia. Pregunte cómo se han sentido comiendo comida más nutritiva, qué dificultades han tenido para hacerlo. Pida que den ideas de qué otras formas pueden proteger su cuerpo.

\section{Introducción al Tema:}

Forme grupos de tres participantes cada una y entregue a cada grupo un papelógrafo que dice: "Mi cuerpo está en peligro cuando..." y de tiempo para que en sus grupos hagan un dibujo de las veces en que sienten que su cuerpo está en peligro. Permita que lo presenten a todos.

\section{Teorizar y definir:}

Comparta que así como hay derechos para proteger la alimentación, la educación, la recreación de las personas también los hay para proteger su cuerpo y su salud sexual y reproductiva. Presente el siguiente cartel y lea con las participantes el contenido.

\section{DERECHOS DE MI CUERPO}

Derecho a que se me respete en las prácticas sexuales.

Derecho a que nadie me obligue a tener relaciones sexuales.

Derecho a que solo yo puedo decidir cuándo y quién puede tocar mi cuerpo.

Derecho a la asistencia legal en caso de abuso sexual, violación o acoso sexual.

Derecho al mejor tratamiento médico para cuidar mis órganos sexuales durante

toda mi vida y especialmente durante mi embarazo.

Derecho a conocer sobre mi cuerpo, el cuerpo de los hombres y la salud sexual y

reproductiva.

Derecho a decidir si quiero tener hijos o no, cuándo, cuántos y con quien quiero tener. 


\section{Aplicación a la vida:}

En grupos de tres participantes van a leer la siguiente historia y contestar las preguntas.

"Lupita nació en una familia de 6 niños: 4 varones y 2 mujeres. Ella era la más pequeña. Aunque su familia es campesina a veces no hay suficiente comida para todas y ella por ser mujer y pequeña era la última en comer.

Cuando tenía 6 años, Lupita empezó a asistir a la escuela. Pero, después de dos años, ella tuvo que dejar de asistir, porque no había dinero para enviar a todos. Ella se quedaban en la casa para ayudar a su mamá a cuidar a sus hermanos menores, a hacer trabajos domésticos y a cultivar el maíz. Ya no aprendió sobre su cuerpo, ni sobre sus derechos.

Un día se quedó sola en casa porque su familia fue al campo y ella no se sentía bien. Llegó a la puerta un señor, se supone que era su pariente pero Lupita no lo sentía como pariente, no le tenía confianza. Cuando él vio que Lupita estaba sola en la cama se acercó a ella y la empezó a tocar de una forma que no le gustó para nada a Lupita, se sentía incómoda y con ganas de llorar cada vez que lo veía.

Pida que dialoguen entre ellas haciendo las siguientes preguntas:

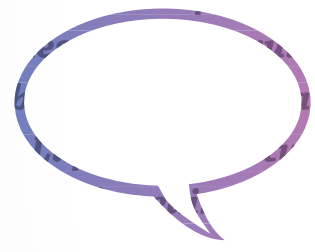

¿Qué derechos del cuerpo que no se respetan en la historia de Lupita?

¿Cuáles son las aciones que están quitándole sus derechos?

¿Qué personas debieran estar cuidando más a Lupita?

¿Qué puede hacer Lupita en la situación en que está?

¿A quién puede pedir ayuda Lupita?

¿Cómo puede la mentora ayudar a Lupita?

Luego de un tiempo pida que todas compartan sus respuestas para hablar de cada una. Al final escriba en un papelógrafo de título:

¿A quién podemos pedir ayuda para proteger nuestro cuerpo cuando sentimos que está en peligro?

Escriba allí una lista elaborada con las participantes de personas, lugares e instituciones en la comunidad a quienes pueden pedir ayuda. Escriba lo más detallado posible, usando nombres de las personas o como llegar al lugar. Demuéstrele al grupo que usted también está entre las personas a quienes pueden pedir ayuda.

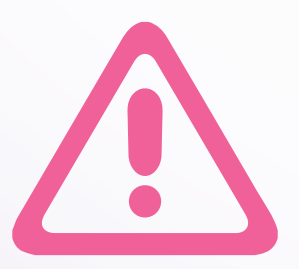

\section{ALERTA:}

Pida que para la próxima sesión pregunten a su mamá sobre cómo fue su primer embarazo y parto. Deben incluir: ¿Edad que tenía?¿Cómo se dio cuenta de que estaba embarazada? ¿Qué hizo cuando tuvo la idea de que estaba embarazada?¿Cómo se sintió durante el embarazo?¿Corrió algún riesgo?¿Alguna enfermedad o malestar de salud?¿Quién la ayudó al momento de dar a luz?¿Qué cuidados tuvo después de dar a luz? 


\subsection{Embarazo, decisión y planificación}

\section{Sesiones de 2 horas}

Al finalizar la

Sesión las

participantes

habrán...
Conocido que con el inicio de la menstruación la adolescente puede quedar embarazada.

Escuchado del riesgo de la mortalidad materna.

- Explicado porqué las mujeres tenemos el derecho a decidir cuándo, cuántos y con quién queremos tener hijos.

Conocido que hay formas de planificar la familia que se quiere tener.

\section{Conceptos Clave}

\section{Embarazo:}

Período de nueve meses de gestación desde la fecundación hasta el nacimiento del bebé.

\section{Mortalidad materna:}

Muertes que ocurren a mujeres cuando están en gestación o acaban de pasar por el parto que son provocadas por su condición de embarazada.

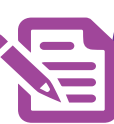

Historias del primer embarazo de las mamás de las niñas (llevadas por ellas). Papelógrafo con síntomas de riesgo

Marcadores

\section{Bienvenida:}

Dé la bienvenida a las participantes, confirmando quiénes están presentes o ausentes. Pregunte si alguna de ellas ha escuchado una historia acerca de cuándo su mamá estaba embarazada de ella o de alguna hermana(o). Permita que cuenten sus anécdotas, agradeciéndoles por compartir esta información íntima de su familia. Pida que adivinen de qué se va a tratar la sesión este día.

\section{Introducción al tema:}

Invite a las participantes a contar las historias que les compartieron sus mamás. Mientras ellas lo hacen escriba en papelógrados las condiciones en las que las Mamá dieron a luz. Pregunta a las participantes:

¿Qué similitudes ven entre las historias?

¿Qué diferencias?

¿Qué edad tenían cuando tuvieron su primer embarazo?

¿Cómo cambió su vida luego de su primer embarazo?

¿Cómo llegga una mujer a estar embarazada?

¿Qué tienen que vé los hombres con rembarazo de una mujer? 


\section{Definición del tema:}

\section{Diga a las participantes:}

Una vez el cuerpo de una niña empieza la maduración, empieza a tener su menstruación como señal de que su cuerpo está preparándose para formar a un bebé. Este bebé se formará si la mujer y el hombre se unen en una relación sexogenital y se da la fecundación gracias a la partición de los dos. El embarazo dura 9 meses para que el o la bebé tenga suficiente tiempo para formarse, crecer y fortalecerse antes de nacer. Cuando una mujer está embarazada o luego de dar a luz su cuerpo se ha dedicado a dar vida y necesita cuidados especiales. Incluso recomiendan que entre un bebé y el otro, la mamá debe esperar por lo menos 2 años para que su cuerpo se recupere. Cuando el embarazo y el parto dificultan el funcionamiento del cuerpo se corre el riesgo de Mortalidad Materna..

Coloque al frente un papelógrafo con las señales de peligro del embarazo y post-parto. Puede incluir:
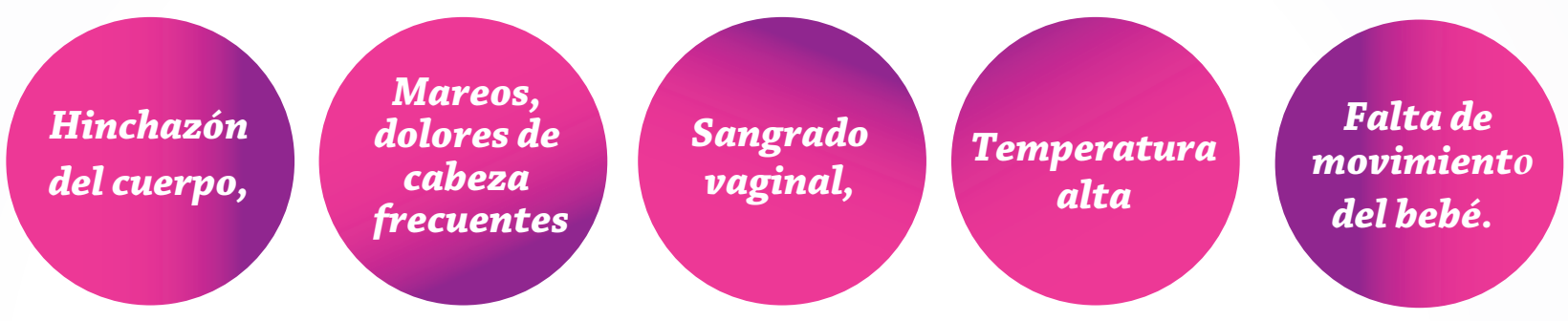

\section{Pregunte a las niñas:}

¿Qué debe hacer una mujer si se encuentra con alguno de estos síntomas?

¿Por qué es importante que haya tiempo entre un bebé y otro bebé?

¿Quién es la principal afectada por un embarazo y parto?

¿Quién debe ser la principal en decidir cuándo y cuántos bebés quiere tener?

¿Por qué las mujeres deben decidir y planificar cuándo quiere tener bebés?

¿Sabían que las mujeres y los hombres pueden planificar si quieren tener o no bebés?

¿Qué han escuchado acerca de la planificación familiar y cómo evitar los embarazos?

Juegue con las participantes la dinámica adivinanzas y expresiones (ver guía de juegos y dinámicas de salud reproductiva) para señalar todos los elementos de los órganos sexuales de la mujer, luego pase a conocer con las participantes los órganos sexuales masculinos, presentando un dibujo que muestre el pene y los testículos. Pida a las participantes mencionar qué nombres usan ellas para nombrar cada parte. Cuando alguna diga "pene" y "testículos" felicite por usar los nombres correctos y escriba estos nombres en un cartel colocándolos para señalar cada uno. Luego presente un cartel con un espermatozoide y explique lo siguiente:

Los testículos son dos, están debajo y a los lados del pene y en ellos se forma el semen, un fluido que contiene los espermatozoides.

El pene es un órgano externo que pueda ser flojo y luego duro.

Los espermatozoides son las células de reproducción masculinas. 


\section{Aplicación a la vida}

\section{Juego de Mito o Verdadero}

Lea las siguientes frases y pida a las participantes que brinquen hacia la derecha si lo que dice es un mito y hacia la izquierda si lo que dice la frase es un dato verdadero. Luego de cada frase compártales la respuesta correcta y pida que todas se pasen al lado que corresponde. Permita un tiempo para que hagan preguntas o para resolver dudas.

Cuando una muchacha ha tenido su primera regla o periodo menstrual, puede quedar embarazada si tiene relaciones sexo-genitales con un hombre. VERDADERO

Es poco saludable que una muchacha se bañe o nade durante su menstruación FALSO

Una muchacha no puede quedar embarazada si ha tenido relaciones sexo-genitales pocas veces.

\section{FALSO}

Una mujer puede evitar quedar embarazada si conoce su periodo fértil $y$ otras formas de evitar el embarazo. VERDADERO

El hombre es quien debe decidir cuántos bebés y cuándo los van a tener. Mientras la mujer acepta y sigue sus órdenes.

\section{FALSO}

Existen mecanismos para evitar tener bebés y las mujeres tenemos

derecho a conocerlos, exigirlos y usarlos.

VERDADERO 


\subsection{Comunicación asertiva cuando me comunico}

Al finalizar la

Sesión las

participantes

habrán...
Experimentado la comunicación agresiva, asertiva y pasiva.

Entendido por qué una buena comunicación es un medio importante para hacer valer y respetar la dignidad propia y de los otros.

Practicado técnicas que mejoran la comunicación.

\section{Conceptos Clave}

Comunicación:

la transmisión de ideas y mensajes entre dos o más personas, por medio de un lenguaje en común.

Comunicación asertiva: características de comunicarse de forma afirmativa y clara.

Comunicación agresiva: se manifiesta de forma violenta, sin permitir el diálogo, usa acusaciones y no

permite que se presente el diálogo.

Comunicación pasiva: se caracteriza por la timidez, no comunicarse claramente, dificultad

para transmitir la idea central.

\section{Bienvenida:}

Papelógrafo con las palabras Asertiva, Pasiva y Agresiva.

Papelógrafos · Marcadores · Dibujo de un gallo, un conejo y

un gata.

Dé la bienvenida a las participantes, confirmando quiénes están presentes o ausentes. Empiece la sesión intentando comunicarse con ellas pero sin hablar, por medio de señas, permita que ellas sigan sus indicaciones o que alguna de ellas juegue también con el grupo.

\section{Introducción al tema:}

Juegue con las participantes a formar barcos de pasajeros. Diga:

Vamos a jugar, yo les voy a decir "Formen barcos de un número de pasajeros y ustedes se tienen que reunirse en grupitos de esa cantidad". Las que se queden fuera tienen que ser las primera a ser tomadas en cuenta en los siguientes grupos.

Diga la primera vez de forma callada, viendo al suelo, sin ver a las niñas y como haciendo más largo de lo necesario la historia. Diga:

Formen barcos de varios pasajeros, pero no sé de cuantos, tal vez de uno no de dos, o tal vez de tres pasajeros, o tal vez de dos o más pero que no sean de más de cuatro pasajeros, igual dos más uno son tres. 
Vea cómo se confunden porque la comunicación no fue clara y directa. Ahora para dar la segunda instrucción lo hará de forma clara, hablando recio viendo a los ojos a las demás compañeras y diciendo exactamente lo que quiere decir, ni más ni menos.

\section{Formen barcos de 5 pasajeras.}

Para la tercera instrucción hágalo de forma enojada, gritándoles y con más carácter, les puede hablar rápido y si alguna no entiende le contesta mal y sin gusto. Puede decir:

\section{Rápido quiero barcos de 2 pasajeras, apúrense. ¡Dije dos no nueve! ¿Qué pasa en ese grupo?}

Al terminar el juego pregunte:

\section{¿Cómo se sientieron durante el juego?}

¿En qué momentos les fue más fácil/difícil armar los grupos que les pedí?

¿En qué se diferenciaba la forma de pedirles la formación de los gurpos?

La primera vez no fue clara y no se entendió, la segunda fue muy clara y directa no se dieron confusiones, la tercera vez fue muy pesada y mandona tampoco se entendió claramente qué era lo que quería o porqué estaba enojada.

¿Cuándo se sientieron más seguras y tranquilas por mi forma de dar las instrucciones?

\section{Teorizar y definir:}

Apunte lo que le dijeron en un papelógrafo anotando las tres formas de comunicarse:

\section{- Confusa, indirecta, poco clara.}

\section{- Muy clara, breve y directa.}

\section{- Enojada, mandona y gritona.}

Presente un dibujo de un gallo, un conejo y una gata. Lea con ellas los conceptos clave y pida que mencionen cuál de las tres formas de comunicarse de sus compañeras es pasiva, cuál es agresiva y cuál es asertiva. Coloquen los dibujos según el orden que corresponde en el papelógrafo donde escriben las tres formas de comunicarse. Pregunte:

¿Cuál es la mejor forma de comunicar una idea, un mensaje, una sensación? 


\section{Aplicación a la vida:}

Comparta con las participantes la siguiente historia:

Josselyn está en cuarto grado de primaria y es muy buena para estudiar. Tan buena es que siempre saca la mejor nota de la clase en sus trabajos. Los compañeros de su clase, especialmente los hombres les gusta molestarla para hacerla sentir mal por sus notas y para ellos tratar de sentirse mejor porque no logran ganar un solo examen. Esta mañana la seño devolvió tareas y otra vez felicitó a Josselyn por su excelente trabajo, pero a ella no le gustó porque sabía que la iban a molestar. Al recreo no había llegado a la puerta del salón cuando ya se habian juntado los niños para empezar a molestarla. Josselyn sintió algo muy dentro de su estómago que les quería decir y....

Pida a las participantes que formen tres grupos. Entregue a cada uno un papelógrafo y un marcador. Solicite que en el papelógrafo escriba lo que Josselyn debe decir para ser asertiva.

Luego entregue un pedazo de papel a cada una y pida que escriban en él algo que ha tenido muchas ganas de decir a otra persona pero no se ha atrevido o no ha sabido cómo hacerlo. Una vez todas han escrito su frase, pídales que se reúnan en parejas con alguien a la que le tienen confianza y que le compartan qué es lo que ha querido decir pero no ha sabido cómo. Juntas deben decidir cómo es la mejor forma de decirlo y practicar entre sí. Al finalizar las que quieren pueden compartir con el resto del grupo. 


\section{(b) 2 horas}

Al finalizar la Sesión las participantes habrán...
- Identificado qué lugares pueden ser espacios seguros para las mujeres de su comunidad. - Nombrado con qué personas comparten los espacios seguros y reconocen que es una red de confianza y apoyo.

- Explicado cómo el género afecta la seguridad y el acceso a espacios de la comunidad.

- Conocido medidas de seguridad ciudadana para mujeres y las adaptan a sus comunidades

\section{Conceptos Clave}

Seguridad Ciudadana: Contempla las condiciones que protegen y resguardan el bienestar integral de las mujeres y hombres de una comunidad. Esta contempla el respeto a los derechos humanos y la participación de la ciudadanía en las decisiones que se toman.

Red comunitaria de confianza: Relaciones con otras mujeres y hombres de la comunidad con quienes podemos buscar ayuda y formar espacios seguros para nosotras y otras personas.

Medidas preventivas: Acciones que se realizan ante un riesgo, para evitar que el mismo suceda.

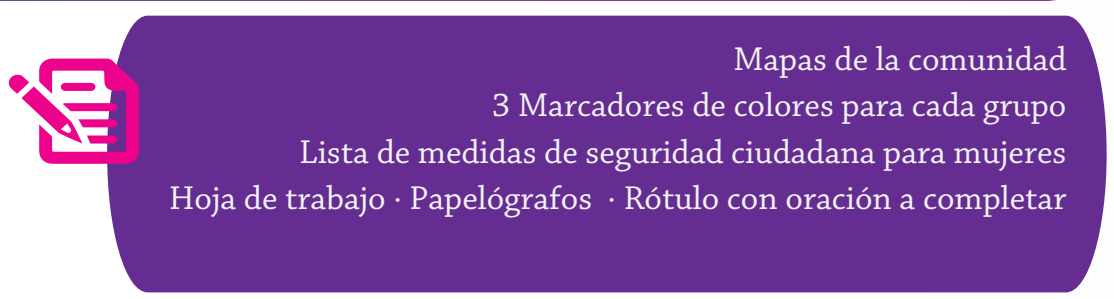

\section{Bienvenida:}

Dé la bienvenida a las participantes, confirmando quiénes están presentes o ausentes. Muestreles su gran alegría de verlas de nuevo y seguir trabajando en las sesiones de Abriendo Oportunidades. Adelante algunos de los temas más interesantes y de las actividades más alegres que estarán tratando durante este año. Comparta con ellas que el día de hoy van a conversar sobre su comundidad y cómo se sienten dentro de ella ahora que ya tienen un año de ser parte de una red de amigas con un espacio seguro.

\section{Introducción al tema}

Coloque un papelográfo grande en el suelo e invite a las participantes a sentarse alredor del mismo y dibuje en él un salón vacío y coloque tambien muchos marcadores y crayones, diga a las participantes: 
Una de ustedes va a empezar la lista diciendo su nombre y una característica del espacio seguro. Luego la que está a su derecho va a presentarse y decir la característica que dijo la primera compañera y agregar una nueva. La tercera va a presentarse, luego va a decir la característica que dijo la primera compañera, la característica que dijo la segunda compañera y va agregar una nueva característica. Seguimos así hasta llegar a la última que va a tener el gran reto de decir todas las características del Espacio seguro. Hay dos condiciones, nadie puede repetir característica y si a alguien se le olvida la podemos ayudar.

Recuerde anotar las características mencionadas por las participantes dentro del dibujo realizado en el papelógrafo para que las tengan a la vista.

Al finalizar el juego pida que todas completen la siguiente oración usando todas las características dichas por ellas: "Este año en nuestra comunidad vamos a lograr más espacios seguros que sean:

Lleve la oración escrita en un papelógrafo.

\section{Teorizar y definir:}

Trabajarán en grupos para identificar los espacios seguros/inseguros para mujeres y hombres. Explique que van a hacer mapas de género que son mapas en los que identifican qué lugares fuera de la casa son espacios seguros para niños, para niñas y cuáles para los dos. Divida a las participantes en grupos de tres, entregándoles una copia del mapa de la comunidad (use como base el mapa hecho al inicio de las sesiones en donde marcan su recorrido) y tres marcadores de colores. Diga a las participantes:

Les estoy entregando un mapa de la comunidad y tres marcadores de colores. Deben discutir sobre los lugares de su comunidad a cuáles van los hombres, a cuáles las mujeres y a cuáles van los dos grupos. Piensen si cada lugar es un espacio seguro para quienes asisten a él. Marquen con un marcador amarillo los lugares seguros para hombres, con el verde los lugares seguros para mujeres y con azul lo lugares seguros para ambos. Recuerden qué es un lugar seguro según lo que dijeron en el juego del inicio de esta sesión.

Permita que trabajen en sus grupos durante 20 minutos. Luego solicite que peguen todos los Papelógrafos al frente para que sean visibles para todo el grupo, invite a las participantes a ver el cartel de los demás grupos. Guíe al grupo en discusión, apuntando las ideas principalales sobre los lugares seguros para mujeres en el pizarrón. Pregunte:

Técnica de facilitación

No olvide incluir los

siguientes lugares en el

mapa:

Milpas altas, Cerros,

Montañas, Senderos

Mercados

Iglesias

Escuela
Salón municipal, Salón

de convergencia

Biblioteca,

Lugar de juegos Locales comerciales Calles de

noche, Carretera

Cantinas

Municipalidad/alcaldía

Terminal 
¿Qué actividades se facilitan para las mujeres por los lugares que son seguros para ellas?

\section{Actividades domésticas, estudiar, jugar.}

¿De qué forma los espacios no seguros dificultan la participación, el liderazgo, los estudios y el trabajo fuera de casa para las mujeres?

Es difícil que hagan cosas fuera del hogar, por el riesgo que corren en estos lugares.

¿A qué lugares tendrían que poder llegar las mujeres para ser activas en su participación, liderazgo, desarrollo etc.?

Centros de convergencia, mercado, municipalidad, transporte, instituto.

\section{Diga a las participantes:}

Estos son los lugares que les gustaría que fueran seguros en la comunidad para el bien de todas las niñas y niños. El que un lugar sea un espacio seguro depende no sólo de dónde está y con qué está hecho, sino que también de las personas que están en ese lugar y la forma en que nos tratan y cómo nos relacionamos con ellas. A veces un espacio seguro puede ser seguro por ratos y en otros ratos dejar de ser seguro, dependiendo de quién esté allí y qué propósitos tiene. Regresen a sus grupos y escriban con qué personas de la comunidad pueden trabajar en equipo para que los espacios no seguros para mujeres sean seguros.

Presente un papelógrafo con medidas de seguridad. Diga a las participantes:

En lo que se transforman estos espacios seguros hay medidas que podemos tomar para proteger nuestra seguridad ciudadana. Vamos a leer juntas las medidas que nos propone este folleto y les invito a que mientras las leamos identifiquemos en el mapa en qué lugares o momentos podemos aplicar cada una y cómo podemos aprovecharlas en nuestra vida cotidiana

\section{Aplicación a la vida:}

Invite a las participantes a trabajar la Hoja de Trabajo "Espacios Seguros" y pensar en dónde pasan tiempo, puede ser en su casa, la escuela, con el grupo de Abriendo Oportunidades, la iglesia, o en las casas de sus amigas. De estos lugares ellas deben indicar qué tanto consideran que es un espacio seguro, marcando una estrella si el espacio no es seguro, dos estrellas si a veces es y otras no es seguro, y tres estrellas si siempre es seguro. Para cada lugar pueden escribir qué podría hacerse en ese espacio para convertirlo en uno seguro y con qué personas podrían trabajar para eso. Al finalizar se abre la oportunidad de que compartan sus respuestas de forma voluntaria entre ellas. Lo interesante aquí será construir ideas cómo ir ganando espacios seguros en su comunidad. 

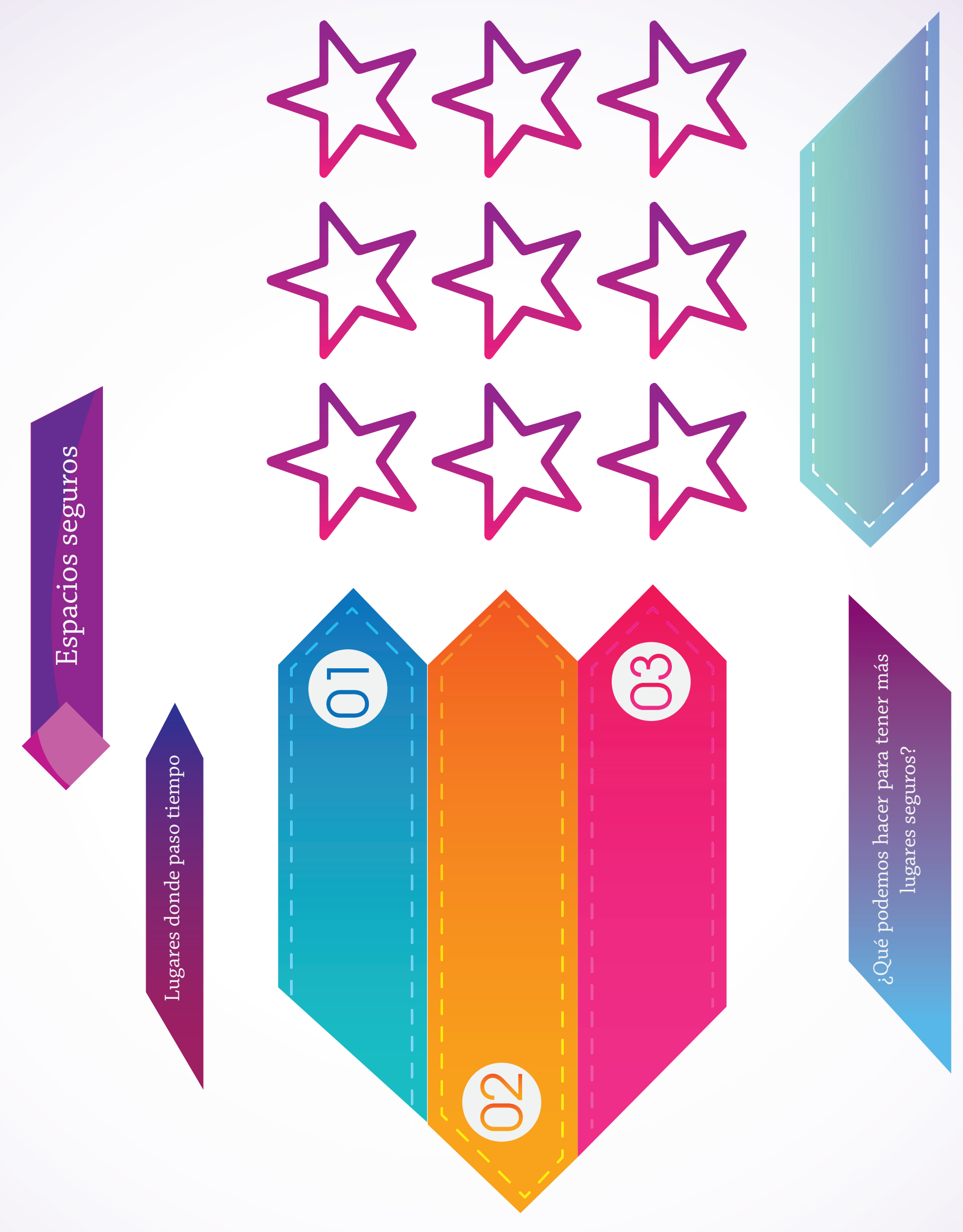


\subsection{Nutrición}

\section{Al finalizar la \\ Sesión las \\ participantes \\ habrán...}

- Aprendido prácticas de la buena nutrición.

- Conocido síntomas, signos y efectos de la desnutrición.

- Formulado estrategias para prevenir la desnutrición según la olla alimentaria.

\section{Conceptos Clave}

Necesidad: Exigencia de algo que nos falta parar completar una meta, estar bien, sobrevivir.

Utilidad: Cualidad que satisface una necesidad.

Elección: Capacidad de escoger entre una cosa u otra cosa según nuestras necesidades y preferencias. Presupuesto: Planificación de ingresos y gastos

Satisfacción: Sensación de gusto y bienestar.

Ingreso: Dinero que recibimos de regalo o como pago de un trabajo.

Gasto: Dinero que pagamos por las cosas o servicios.

\section{Bienvenida:}

Dé la bienvenida a las participantes, confirmando quiénes están presentes o ausentes. Pregunte cómo se sienten de energías en este día y también qué comieron y qué actividades han realizado. Busque si logran identificar la relación entre lo que comieron y la forma en que se sienten.

\section{Introducción al tema:}

Entregue a cada una medio papelógrafo y pídales que escriban lo que han comido en todo el día. Lo deben hacer de forma individual, usted puede irles mencionando los tiempos de comida mientras ellas apuntan las comidas. No tienen que apuntar sus nombres en el papelógrafo. Pida que dejen los papelógrafos en el suelo formando un gran círculo.

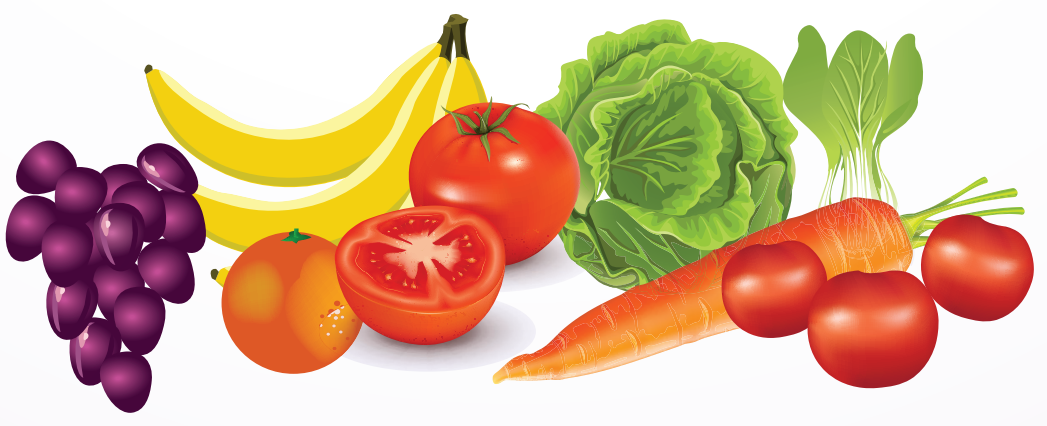


Deben pasar todas viendo los demás papelógrafos y al finalizar reflexionar juntas por medio de las preguntas siguientes:

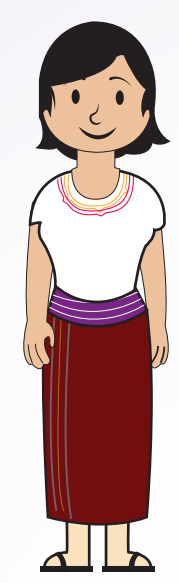

¿Qué es lo que más comen las jóvenes de esta comunidad?

¿Qué es lo que menos comen?

¿Qué es lo que más accesible tienen para comer?

¿Qué quisieran comer más pero no es accesible?

¿Comen todas por igual?

- ¿Qué aprenden de lo que comen las mujeres jóvenes de esta comunidad?

- ¿Es suficiente para el trabajo y el esfuerzo que realizan cada día?

\section{Teorizar y definir:}

Explique al grupo que se ha creado una olla nutricional especial para Guatemala, en la que se sugiere qué es lo que debemos comer y cuántas veces a la semana según alimento. Es un esquema que permite ver que recibamos lo que necesitamos para desarrollar todos los trabajos que tenemos que hacer y además crecer y estar sanas.

Entregue a cada una la Hoja de Lectura Olla Nutricional, lean juntas la información.

Pueden ir comentando cuáles alimentos son más fáciles de conseguir y con qué frecuencia los están consumiendo o no.

Nuestra salud y nuestros ánimos para la vida dependen de lo que comemos y la forma en que comemos. Comer no es lo mismo que nutrirse. Cada cuerpo necesita cierto tipo de nutrientes para estar en buenas condiciones y nutrirse de diferentes alimentos para aprovechar toda la riqueza que tiene la tierra.

Coloque una olla nutricional gigante al frente y entregue a cada participante un papel con el dibujo de uno de los elementos que integra la olla y diga las siguientes instrucciones:

Cada una de ustedes tiene un dibujo que representa el tipo de nutrientes que pertenece a uno de los tipos de alimentos de la olla nutricional. Cada una debe pasar al frente y compartir qué alimento le tocó y dar un ejemplo de alimento que contiene ese tipo de nutrientes. Hasta que todas hayan pasado. El reto está en que ninguna puede repetir, la idea es sacar la mayor cantidad de alimentos nutritivos posible.

\section{Aplicación a la vida:}

Las participantes trabajarán en parejas de amigas. Van a comparar la lista de lo que comen con la olla nutricional para Guatemala, para identificar qué necesitan comer más y qué necesitan comer menos. Es impor-tante que la mentora de grupo acompañe de cerca cada grupo para identificar a qué área pertenecen los alimentos que mencionan las participantes.

Invite a las participantes a realizar la hoja de trabajo "Mi nutrición". Pueden escribir qué van a comer para cuidar bien sus cuerpos, porqué es necesario comer bien y porqué merecen comer bien.. 


\title{
Mi Nutrición
}

\author{
¿Qué debo comer?
}

¿Por qué es importante comer bien?

¿Qué pasa si no como bien?

¿Qué puedo hacer para comer bien? 


\subsection{Fertilidad, fecundación y embarazo}

2 horas
Al funalizar la
Sesión las
- Conocido el proceso de fecundación que deriva en embarazo.
participantes
habrán...
- Discutido acerca de mitos y verdades acerca de la fecundación y el embarazo.
- Explicado porqué la mujer tiene el derecho de decidir cuántos, cuando y con quién quiere tener hijos.
- Identificado que una mujer puede decidir planificar para evitar tener hijos.

\section{Conceptos Clave}

Periodo fértil: Momento en el ciclo durante el cual una mujer puede quedar embarazada al tener relaciones sexogenitales con un hombre.

Fecundación: Proceso mediante el cual un espermatozoide ingresa al óvulo, produciendose una célula fertilizada que al pegarse al útero de la madre se desarrollará en un feto.

Embarazo: Periodo de nueve meses de gestación desde la fecundación hasta el nacimiento del bebé.

Cigoto: La únion entre el óvulo y el espermatozoide, del que se desasrrolla el feto.

Óvulo: Célula reproductiva d elas mujeres, se encuentra en el ovario en el extremo de cada trompa de falopio.

Espermatozoide: Célula reproductiva del hombre, se encuentra en el semen que el hombre deposita en la vagina de la mujer.

\section{Bienvenida:}

Fotos del óvulo, espermatozoide, el óvulo fecundado por el

espermatozoide, el cigoto implantado en el útero.

Cartel gigante de los órganos sexuales femeninos.

Rótulos con los conceptos clave para que sean vistos por las participantes. Papelógrafos, Marcadores

Dé la bienvenida a las participantes felicitándolas por seguir asistiendo a las reuniones.

Pregunte por quienes están ausentes de la sesión. Pregunte si alguna de ellas tiene hermanos o hermanas menores y pida que comparta lo que se recuerda del embarazo de su mamá, del parto y los primeros días después del nacimiento. Diga que van a conocer un poco más de todo ese proceso y sobre todo de cómo se inicia un embarazo.

\section{Introducción al tema:}

Inicie por recordar los nombres y la ubicación de los órganos sexuales femeninos. Coloque al frente el cartel sin señalar los nombres de los órganos. Forme 7 grupos de participantes y a cada grupo entregue un rótulo con el nombre de un órgano (útero, ovario, óvulo, endometrio, trompas de Falopio, vagina, cérvix). En sus grupos recordarán en dónde se ubica ese órgano y cuál es su función. Cuando indiquen que están listas, pida que pasen al frente grupo por grupo, colocando el nombre en el lugar del órgano que corresponde y diciendo su función a sus compañeras. Usted esté pendiente de confirmar que los nombres y las funciones son todas correctas, en caso de que haya un error aproveche para clarificar en el momento. Pregunte a las participantes:

¿Cuáles de estos órganos conocen ustedes que participan en el embarazo?

¿Saben qué es la fecundación?

¿Cómo queda embarazada una mujer?

¿En dónde se desarrolla el feto durante el tiempo del embarazo? 


\section{Teorizar y definir:}

Explique a las participantes que los principales protagonistas de la fecundación son el ÓvULO de la mujer y un ESPERMATOZOIDE.

Muestre el rótulo con la imagen del espermatozoide que tiene de título ESPERMATOZOIDE y el concepto clave. Siga contándoles que cuando el óvulo y el espermatozoide se unen se da la FECUNDACIÓN.

Enséñeles la imagen del óvulo y el espermatozoide unidos con el título FECUNDACIÓN. Luego explique que esta unión solamente puede pasar durante un tiempo del mes que es conocido como PERÍODO FÉRTIL. Coloque el rótulo con la definición de período fértil al frente para leer juntas. Comente que cuando se da esa unión dejan de ser dos células independientes y se convierten en una sola que se llama cigoto. Muestre la imagen del cigoto con el título y la definición del CIGOTO en un cartel. Termine la breve explicación comentando que durante nueve meses, esa célula crece y se convierte en un FETO que permanece dentro del útero durante nueves meses, llamado este tiempo EMBARAZO.

\section{Enséñeles la imagen del feto dentro del útero durante el desarrollo del embarazo y coloque las definiciones de las palabras la frente.}

Pida que luego de escuchar esto señalen qué órganos reconocen que participan en la fecundación y el embarazo en el cartel grande del frente. Diga que va a explicar con detalle cómo se da todo el proceso de fecundación para que una mujer quede embarazada y que ellas pongan mucha atención. Pida que una de las compañeras pase al frente y escriba en un papelógrafo cada uno de los pasos que usted va indicar.

Mientras muestra el proceso de cada paso en el cartel con los órganos sexuales internos diga a las participantes:

1. Durante el PERÍODO FÉRTIL de la menstruación el óvulo se traslada por la trompa de Falopio hacia el útero.

2. En ese tiempo, la mujer tiene relaciones sexogenitales y su pareja deposita semen en su vagina. El semen contiene millones de espermatozoides, que son las células reproductivas de los hombres.

3. Los espermatozoides nada rápidamente hasta encontrarse con el óvulo que está en la trompa de Falopio. Los espermatozoides tratan de ingresar en el óvulo todos al mismo tiempo.

4. Solamente un espermatozoide logra penetrar dentro del óvulo y juntos se convierten en cigoto.

5. El cigoto sigue viajando por la trompa de Falopio hacia el útero.

6. Una vez en el útero el cigoto se vincula al endometrio, se pega a la pared de sangre que tiene el útero de la cual empieza a alimentarse y es protegido.

7. Estando alli el cigoto crece hasta convertirse en un feto con cerebro, corazón, extremidades, ojos y todas las partes del cuerpo que tenemos las personas. 
Pida que la voluntaria que ha escrito los pasos en el papelógrafo comparta cada uno de los seis pasos para ver si ha logrado apuntar todo en orden como es. En caso de que haya un error corríjalo en el momento.

Pida que formen siete grupos, sortee entre los grupos papeles numerados del uno al siete y entregue un papelógrafo y marcadores a cada grupo. Pida que de acuerdo al número que les tocó dibujen en el papelógrafo el momento de la fecundación que corresponde.

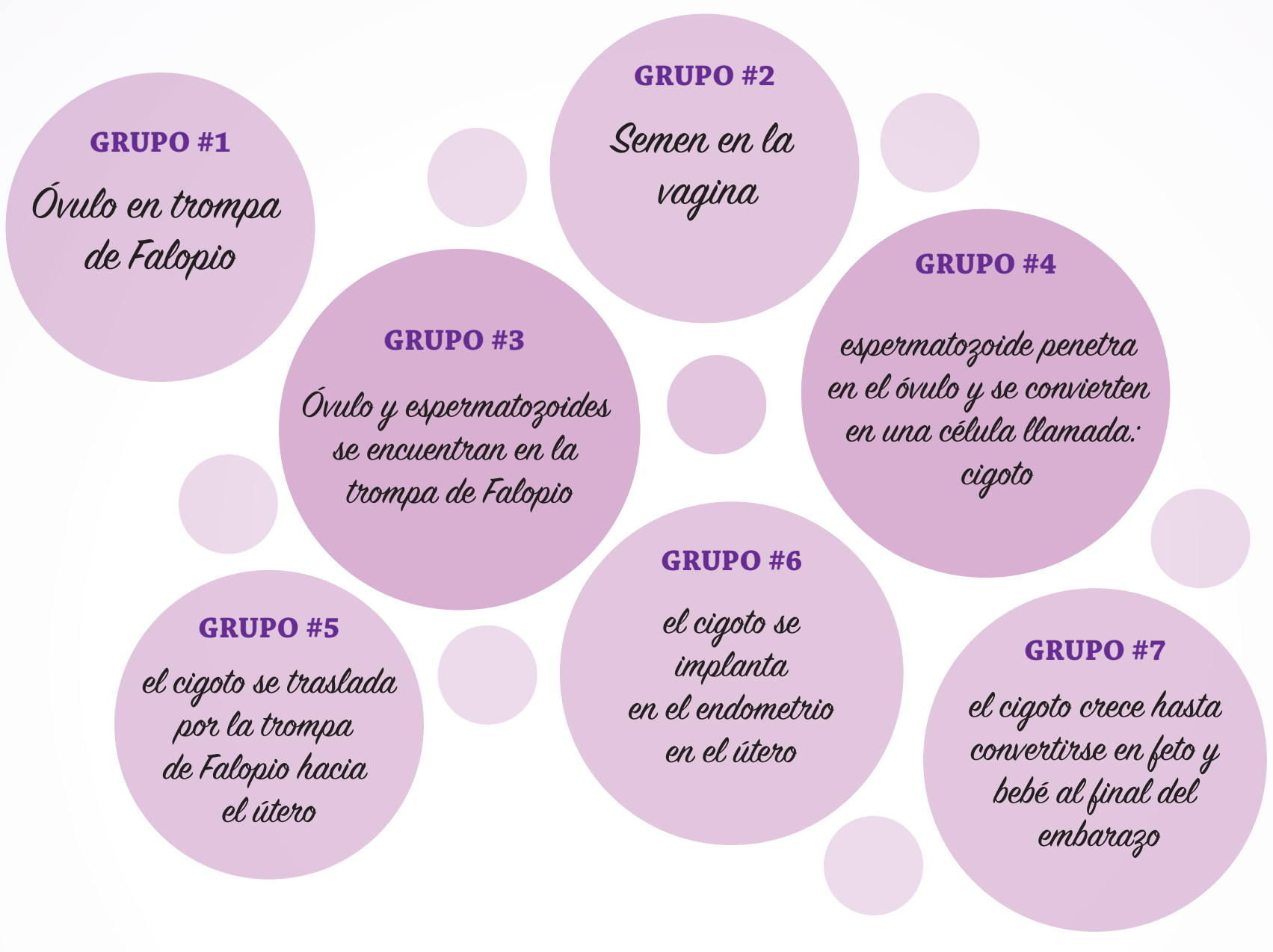

Después de 10 minutos de trabajo en grupo, pida a cada grupo pasar al frente, en el orden que corresponde, y muestren el papelógrafo que hicieron explicando cada paso. 
Al terminar, pida que cada una escriba los 7 pasos en una hoja en blanco, puede hacer dibujos si prefiere. Al terminar pregunte en plenaria:

¿Qué es el período fértil?

El tiempo durante el cual puede quedar embarazada una mujer.

¿En dónde se encuentra el óvulo durante el período fértil?

\section{En la trompa de falopio}

¿De dónde surge el espermatozoide?

Del semen del hombre

¿Cómo llega el espermatozoide a la vagina de la mujer?

Por medio del semen que deposita el hombre en la vagina de la mujer cuando eyacula

¿En qué órgano sexual de la mujer se encuentran el óvulo y el espermatozoide?

Dentro de la trompa de Falopio

¿Qué es la fecundación?

El momento en el que el espermatozoide ingresa al óvulo.

¿Cómo se llama a la nueva célula que se forma de la unión entre el espermatozoide y el óvulo?

Cigoto

¿De dónde se alimenta el cigoto durante el embarazo?

Del endometrio, el recubrimiento de sangre que se encuentra en la pared del útero

¿Cuánto tiempo dura el embarazo?

Nueve meses

¿Qué pasa con la menstruación durante el embarazo? ¿Por qué?

No se presenta, pues el feto se está alimentando y protegiendo de la capa de sangre

\section{Aplicación a la vida:}

Coloque al frente dos carteles, uno que diga mito del lado derecho y otro que diga verdadero del lado izquierdo. Pida a las participantes colocarse en una fila entre ambos carteles. Explique que usted irá mencionado ciertas ideas acerca del embarazo, las mujeres y los hombres. Si ellas creen que lo que usted ha dicho es verdad, deben saltar hacia el lado que diga VERDADERO y si creen que es falso deben saltar hacia el lado que diga MITO.

Luego de cada idea, usted dirá si es mito o dato y les ofrecerá más información sobre el tema. 


\section{IDEA}

\section{VERDADERO/MITO}

Cuando una muchacha ha tenido su primera regla o período

menstrual, puede quedar embarazada si tiene relaciones

VERDADERO

sexo-genitales con un hombre.

Es poco saludable que una muchacha se bañe o nade durante su

regla (período menstrual).

MITO

No tener relaciones sexogenitales es la única forma $100 \%$

efectiva de no quedar embarazada.

VERDADERO

Una persona adolescente necesita el permiso de sus padres para

tener información de cómo evitar embarazos en el centro de

MITO salud.

Una mujer no puede quedar embarazada si ha tenido relaciones

sexogenitales pocas veces.

MITO

La ducha vaginal después de tener relaciones sexogenitales

previene el embarazo.

MITO

Cuando un hombre se ha excitado y tiene una erección tiene que

eyacular porque si no se hace daño.

MITO

Una mujer no puede quedar embarazada si tiene relaciones

sexogenitales pero su pareja no eyacula dentro de su vagina.

MITO

Una mujer puede quedar embarazada en su primera relación sexual.

VERDADERO

Un hombre puede provocar un embarazo al tener relaciones sexogenitales en cualquier momento de su vida desde que empieza a eyacular.

Se pueden tomar medidas para no quedar embarazada.

VERDADERO

La mujer puede decidir cuándo, cuántos y con quién quiere tener hijos e hijas.

VERDADERO 


\subsection{Derechos sexuales reproductivos}

Al finalizar

la Sesión las

participantes

habrán...
- Conocido sus derechos reproductivos.

-Reconocido la aplicación de los derechos en su comunidad.

- Identificado los factores culturales, sociales, económicos y políticos que afectan la salud reproductiva de las mujeres.

\section{Conceptos Clave}

Derechos sexuales y reproductivos:

Conjunto de derechos destinados a proteger la salud sexual y reproductiva de mujeres y hombres de todas las edades.

Marcadores · Tarjetas con los derechos · Papelógrafo

\section{Bienvenida:}

Dé la bienvenida a las participantes, confirmando quiénes están presentes o ausentes. Pregunte cómo se sienten hoy con lo que vieron la sesión pasada sobre cómo se queda embarazada y motívelas a que le hagan más preguntas en relación con el tema.

\section{Introducción al tema:}

Pida que se junten en grupos de tres o cuatro, según sean amigas. Sortee entre los grupos papelitos que tiene escrito una forma de relación.

\section{a. novio y novia}

b. esposo y esposa

c. tíos y sobrinas

d. primos grandes y primas pequeñas 
Cada grupo debe escribir una situación relacionada con la sexualidad entre ambas personas que pasa a veces en su comunidad pero que ellas piensan nunca debería darse. Por ejemplo, que pasa entre novios y novias que no debería darse, qué pasa entre esposo y esposa que no debería darse...Al terminar van a presentar al resto del grupo el caso. Usted debe escribir en un papelógrafo las situaciones que se van mencionando.

Algunas que pueden surgir:

Piden a la novia la prueba de amor y la obligan a tener relaciones

El esposo no usa condón

La esposa tiene relaciones aunque no quiere

Los primos abusan de la prima, la tocan

Las madres no dan información a sus hijas sobre la menstruación

Los tíos aprovechan de las sobrinas...

Cuanto tenga la lista de las situaciones, revise junto con ellas cada situación y pida que le den una sugerencia de cuál sería una norma para que esa situación ya no existe. Por ejemplo si la primera situación es que le piden la prueba de amor a la novia y la obligan a tener relaciones la norma podría ser:

Nadie puede obligarte a tener relaciones sexuales, Tú puedes escoger cuándo y con quien quieres tener relaciones sexuales...

así con cada caso.

Al haber hecho normas para todos los casos, explique que estas normas ya existen y se les llama: Derechos sexuales y reproductivos. Pregunte al grupo

¿Por qué serán derechos SEXUALES y REPRODUCTIVOS?

Por que protegen la sexualidad y las decisiones sobre la reproducción.

¿Si son derecho a quiénes se aplican?

A todas y todos, incluidas nosotras

¿Quieren conocerlos? ¿Creen que les puede servir en algo?

Sí. Conocerlos permite tener más información para mejores decisiones, permite protegernos y defendernos y alejarnos de alguien que nos esté haciendo daño.

\section{Teorizar y definir:}

Comparta que así como hay derechos para proteger la alimentación, la educación, la recreación de las personas también los hay para proteger su salud sexual y reproductiva. Entregue a cada participante una tarjeta con uno de los derechos sexuales y reproductivos que se enumeran a continuación. Pida que las lean en voz alta. 


\section{DERECHOS SEXUALES:}

1. Derecho a decidir las preferencias sexuales y las formas de protección para que las prácticas sexuales sean seguras.

2. Derecho a ejercer la sexualidad sin sufrir discriminación, coacción ni violencia.

3. Derecho a la igualdad, al respeto mutuo, la responsabilidad y el consentimiento compartido en las prácticas sexuales.

4. Derecho a la asistencia legal en caso de abuso sexual, violación o acoso sexual.

5. Derecho a prevención, diagnóstico y tratamiento ante posibles infecciones de transmisión sexual.

6. Derecho a acceder a la educación e información para poder decidir y disfrutar de manera plena la sexualidad y la maternidad y paternidad de forma responsable

\section{DERECHOS REPRODUCTIVOS:}

1. Derecho a decidir libre y responsablemente tener o no tener hijos, cuándo, cuántos y con quién tenerlos.

2. Derecho a la información clara y oportuna sobre las distintas opciones en anticoncepción.

3. Derecho a tener garantizado el acceso a los diversos métodos anticonceptivos, para poder elegir libremente el de preferencia.

4. Derecho a todos los métodos de la planificación familiar.

5. Derecho a ser atendida en privacidad, confidencialidad, seguridad y respeto por parte del personal de salud.

\section{Derecho a una atención humanizada en el embarazo, parto y puerperio.}

7. Derecho a servicios de información en situación de embarazos no deseados o inoportunos, brindados con respeto y calidad de atención.

8. Derecho a métodos confiables de diagnóstico y de tratamiento de enfermedades del aparato reproductivo.

9. Derecho a tener educación e información para poder decidir y disfrutar de manera plena la vida reproductiva.

Luego de leer cada uno, todo el grupo debe identificar cuál de las situaciones que se dan en la comunidad tiene que cambiar por el derecho mencionado. Luego de que se repasaron todos los derechos sexuales y reproductivos, pida que en tríos traduzcan a su idioma los tres que consideran más relevantes para las mujeres de su comunidad y luego los presentan a todo el grupo. 


\title{
4. Aplicación para la vida:
}

\author{
Narre la historia de: "La Vida de Lupita”:
}

"Lupita nació en una familia de 6 niños: 4 varones y 2 mujeres. Ella era la cuarta; además, la niña era la más pequeña. Su familia ganaba dinero cultivando y vendiendo un poco de maíz. Frecuentemente, no había suficiente comida para toda la familia. Como la mayoría de familias en su comunidad, su papá y sus hermanos comían primero; luego, comían ella y su hermana; finalmente, comía su mamá. Lupita crecía lentamente y esto era considerado normal.

Cuando ella tenía 6 años, Lupita empezó a asistir a la escuela. Pero, después de dos años, ella tuvo que dejar de asistir, porque no había dinero para enviar a todos los hijos a la escuela. Sus dos hermanos mayores seguían estudiando mientras Lupita y su hermana mayor se quedaban en la casa para ayudar a su mamá a cuidar a sus hermanos menores, a hacer trabajos domésticos y a cultivar el maíz.

Cuando ella tenía 12 años, la familia había mejorado sus finanzas. Aprendían nuevas técnicas de agricultura y estaban vendiendo más maíz. Lupita quería volver a la escuela, pero su papá no se lo permitía. La escuela estaba lejos y él estaba preocupado por su seguridad. Además, él le decía a su esposa que Lupita se casaría pronto y que no era necesario que ella tuviera educación. Su hermana mayor, María, que tenía 17 años, se había casado hacía años y ya tenía un hijo.

A los quince años, Lupita se casó con Eduardo y se fue a vivir a la casa de él. Después de cuatro meses, ella estaba embarazada

y, a los 18 años, ya tenía tres hijas. Siempre estaba cansada y su salud era débil. Frecuentemente, se sentía deprimida y aislada. Aunque ella no sabía leer, sí había oído hablar sobre la planificación familiar. En muchas oportunidades, Lupita le dejó entrever a Eduardo que ella necesitaba descansar. Eduardo se enojó tanto que la golpeó. Eduardo le hizo ver que ella todavía no

le había dado un hijo varón; por otra parte, le argumentó que la planificación familiar no es natural. Lupita, tomando en cuenta que la había regañado, ya no habló más del asunto.

La salud de Lupita continuaba empeorando. Ella había ido al doctor muchas veces, para ser tratada en su área genital. Cada vez, las enfermeras de la clínica de salud local, le decían que tenía que usar condones para prevenir las enfermedades. Pero, Lupita pensaba que solo las prostitutas usaban condones; además, seguramente Eduardo los rechazaría. El cuarto hijo de Lupita era un varón; Eduardo estaba muy contento. Y, ya estaba anticipándose a su segundo y tercer hijo. Mientras, Lupita se estaba sintiendo más triste y cansada."

Pide a las participantes que identifiquen los factores que contribuyen a que Lupita tenga un mal estado de salud tanto físico como emocional. Piensen en los factores culturales, sociales, económicos y políticos que están afectando a Lupita en su vida.

Nutrición: pobre cuando era niña,

- Falta de oportunidad de educación por la discriminación de sexo,

- Analfabetismo, Esposo toma decisiones para la familia,

- Preferencia por los hijos varones,

- Falta de educación sobre salud y falta de apoyo del centro de salud.

Reflexione con el grupo haciendo las siguientes preguntas:

¿Conocen mujeres que vivan en las mismas condiciones que Lupita?

- ¿Es aceptable la vida de Lupita? ¿Por qué sí o por qué no?

- ¿Qué podemos hacer para mejorar la vida de las mujeres que han vivido la misma experiencia de Lupita?

- ¿Cuáles de los derechos de Lupita no se han respetado?

¿Qué derechos tenemos que trabajar más para que sean respetados en esta comunidad? 


\section{Somos muchas y diversas} trabajando unidas

2 horas

Al finalizar

la sesión las

participantes

habrán...
- Conocido a mujeres notables de su comunidad.

- Escuchado las historias de mujeres notables de la comunidad.

- Conocido estrategias para sobrevenir los retos que la vida en la comunidad presente.

\section{Papelógrafo $\cdot$ Marcadores $\cdot$ Hoja de trabajo}

\section{Bienvenida:}

Dé la bienvenida a las participantes, confirmando quiénes están presentes o ausentes. Comparta con ellas que el día de hoy van a conocer y conversar con mujeres notables de su comunidad.

\section{Introducción al tema:}

Diga a las participantes que van a conocer a algunas mujeres notables de la comunidad que usted ha invitado a la sesión. Que son mujeres que han hechos cosas más allá de lo que la comunidad espera que ellas hagan y han alcanzado las metas que se trazaron. Se encontrarán con estas mujeres para que ellas les compartan sus experiencias, sus metas, retos y estrategias para alcanzar sus logros.

\section{Teorizar y definir:}

Presente a las mujeres invitadas al grupo de todas las participantes indique su nombre, algo de su historia de vida, en qué trabaja o con qué grupo participa y porqué se considera que es una mujer notable de la comunidad. Permita que cada invitada se presente a las participantes e invítela a que cuente algo breve de su vida. 
Forme 3 ó 4 grupos (la misma cantidad de invitadas que tiene) entregue a cada grupo una guía de preguntas (como la que entregó a las invitadas) indíqueles que tiene 30 minutos para dialogar y que las preguntas son sólo una guía. Al finalizar cada grupo debe hacer un cartel en el que presenta a la mujer notable (incluyendo la información de las preguntas de la guía) y lo presentará al resto de las participantes.

\section{Pregunte a las participantes:}

¿Qué ven en común entre las mujeres?

¿Qué diferencias hay entre estas mujeres?

¿Qué pasos siguieron estas mujeres para alcanzar sus metas?

¿Qué estrategias usaron para sobrepasar los retos y dificultades con las que se enfrentan?

¿De qué forma lo que ellas están haciendo les permite a ustedes imaginar una vida diferente para sí mismas?

¿Cómo son ejemplo de que las mujeres apoyándose unas a otras somos fuertes y maravillosas?

\section{Técnica de facilitación}

Previo a la reunión, invite a tres o cuatro mujeres notables de la comunidad a presentarse a la sesión para que puedan

intercambiar su experiencia de vida con las participantes. Dígales que el objetivo es que las participantes tengan

referentes de otras mujeres que se han establecido metas y han logrado alcanzarlas sobrepasando a las adversidades

que la vida les ha puesto. Entregue a las mujeres invitadas una serie de preguntas previamente para que puedan

prepararse para el encuentro con las participantes.

¿¿Qué meta tenía para su vida cuando tenía 13 a 18 años?

¿¿Qué metas ha logrado en su vida?

¿Qué pasos siguió para alcanzar esa meta?

- ¿Qué dificultades tuvo que afrontar para alcanzar las metas?

¿Qué estrategias ha usado para sobreponerse a las dificultades?

¿En qué otras mujeres ha encontrado apoyo?

¿Cómo ha podido usted apoyar a otras mujeres?

¿Qué derecho cree que debe ser protegido para todas las mujeres?

\section{Aplicación para la vida:}

Invita a las participantes a identificar una mujer con la que se identifica, puede ser de las invitadas u otra que conocen. Entregue la hoja de trabajo "Foto-espejo" y diga a las participantes que deben dibujar en un cuadrado a la mujer que admiran y en el otro dibujarse a sí mismas destacando las cosas en común que tienen. Luego en el lazo que une a las dos, deben escribir cómo ella puede contribuir al trabajo que realiza la mujer que admira. 


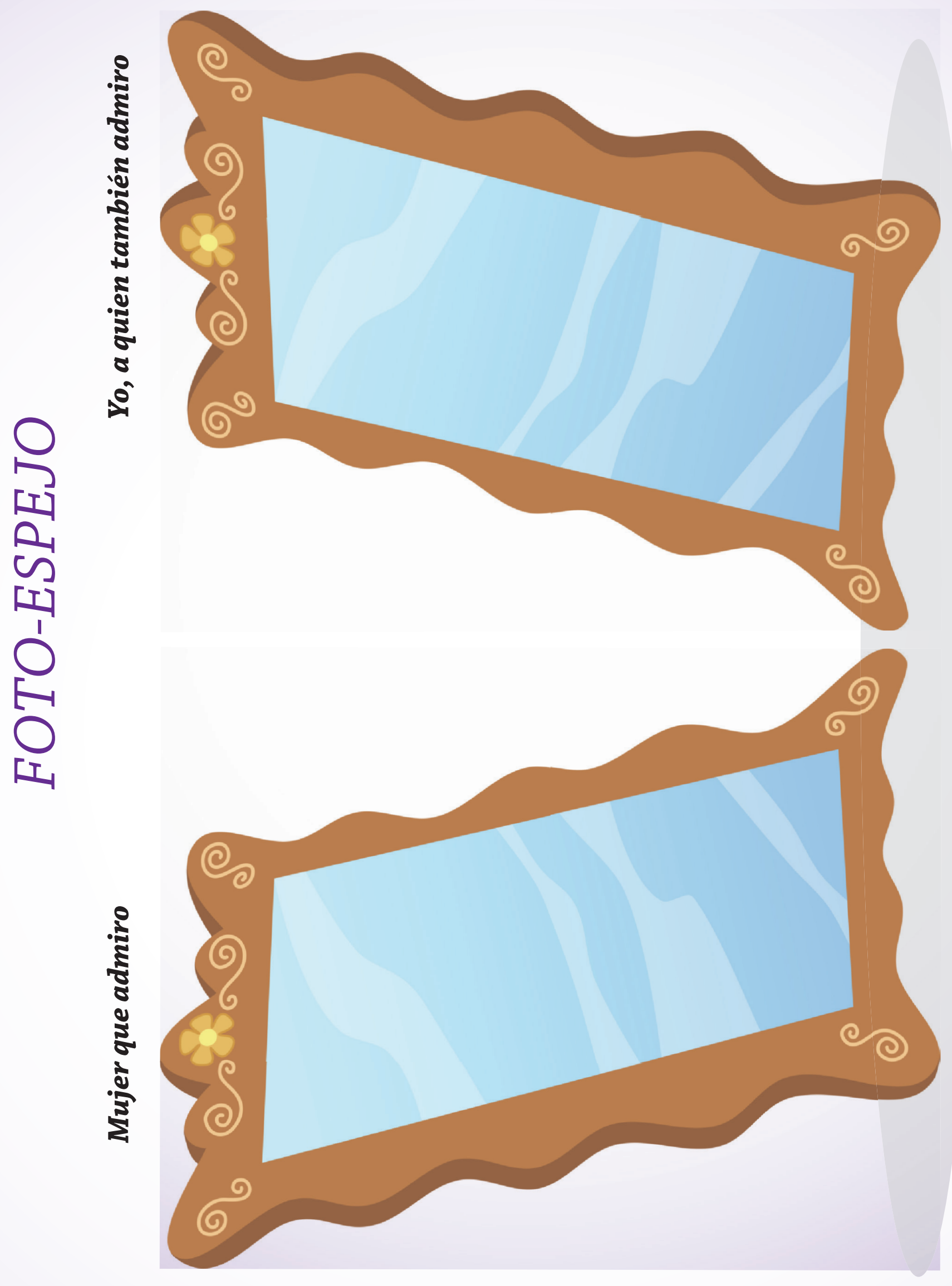




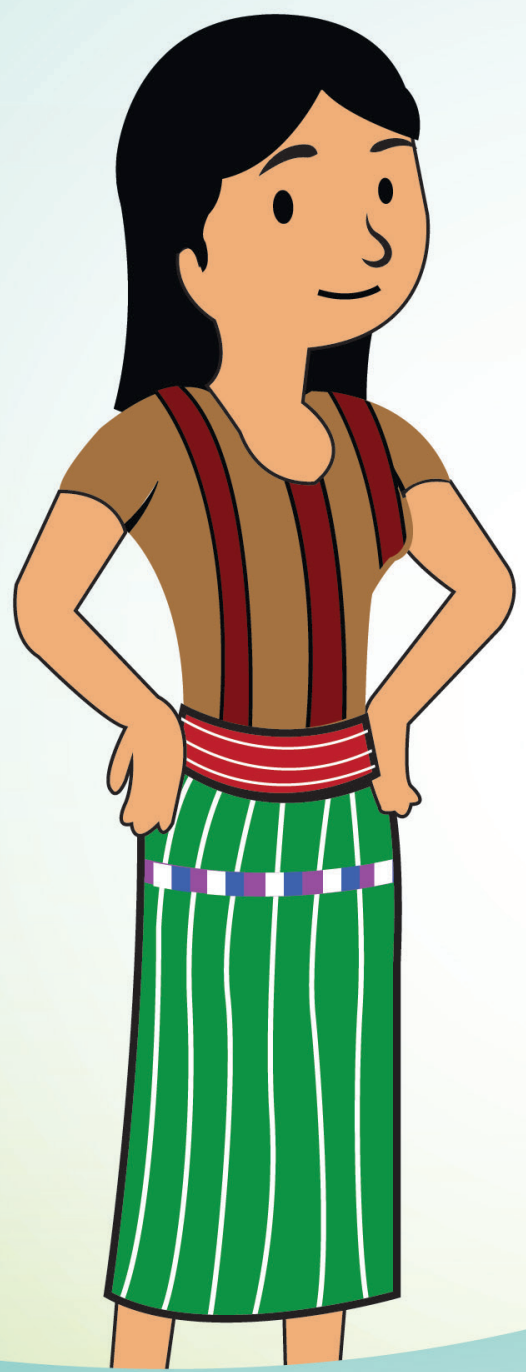

1
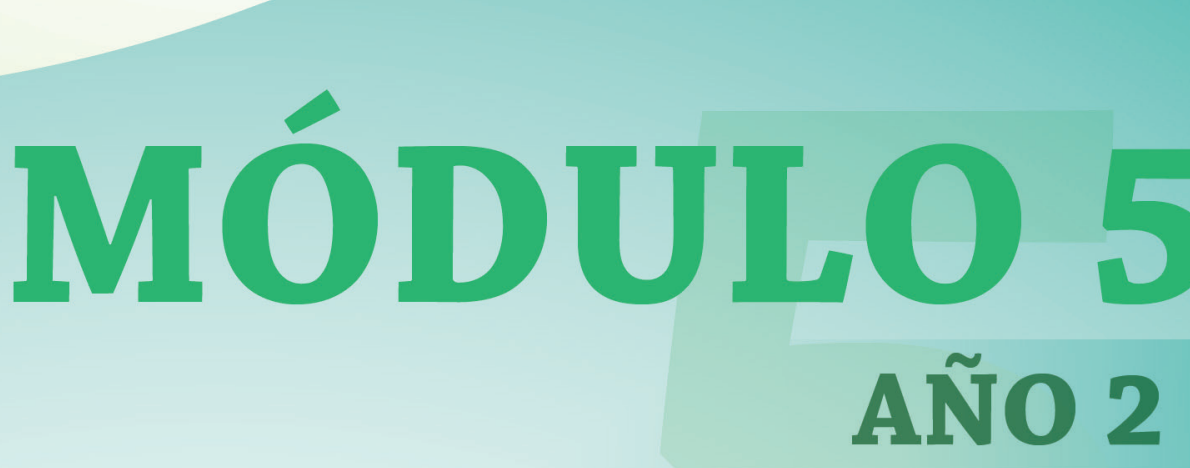

Guía Curricular Integrada 2015 - Population Council 


\section{Créditos}

$\checkmark$ Autoras:

María Cecilia Garcés de Marcilla/Especialista en Educación

$\checkmark$ Paola Broll / Oficial del Programa

- Revisión: Alejandra Munguía/ Coordinador de Campo

$\checkmark$ Diagramación:Isaí de la Cruz

- Equipo Population Council 2015:

$\checkmark$ Directora de Programas: Alejandra Colom

- Supervisor de Monitoreo y Evaluación y oficial de Programa: Ángel del Valle

- Administradora: Ana Lucía Rodríguez

- Mentoras: Elizabeth Vásquez, Claudia Macz, Sonia Chó, Patricia Alva, Maribel Gutiérrez, Fabiola Colop y Rosa Güit 


\section{AÑO 2}

\section{Módulo V}

Este trimestre trabajan tres áreas centrales: Educación Financiera, Prevención de la violencia y Proyección Comunitaria. Ésta última empieza a desarrollarse durante este segundo año con el propósito que al finalizar el período las jóvenes tengan identificadas las necesidades de su comunidad y posibles áreas de trabajo en las que podría incidir para provocar cambios que mejoren la calidad de vida de las niñas y jóvenes, mujeres e indígenas.

\section{Grupo de 8 a 12}

5.1 Educación financiera: Ahorro para estar bien I

5.2 Educación financiera: Ahorro para estar bien II

5.3 Prevención de la violencia: Puedo decidir para protegerme

5.4 Prevención de la violencia: Cambiando la violencia por el respeto entre hombres y mujeres

\section{Grupo de 13 a 17}

5.1 Educación financiera: ¿Quién paga y cómo se distribuyen los servicios públicos que recibimos?

5.2 Educación financiera: El crédito un asunto de responsabilidad

5.3 Prevención de la violencia: Vencemos obstáculos en esta comunidad

5.4 Prevención de la violencia: La violencia se combate con inteligencia, valor y nuestra amigas

5.5 Proyección comunitaria: Vernos de frente

5.6 Proyección comunitaria: Las necesidades de mi comunidad 


\subsection{Ahorro para estar bien}

\section{Grupo de 8 - 12 años}

\section{2 horas}
Al finalizar
la sesión las
- Formado su conciencia sobre el beneficio del hábito del ahorro, ya que en un futuro las puede ayudar
participantes
habran... a alcanzar sus metas.
- Comprendido que el hábito del ahorro es importante para crear un patrimonio.
- Conocido que existen diferentes opciones para ahorrar y proteger el dinero: cooperativas y bancos.

\section{Conceptos Clave}

Economizar: Gastar menos dinero a través de un consumo inteligente.

Ahorro: Parte de los ingresos que se guarda para utilizarla más tarde, ya sea para enfrentar una emergencia o cumplir una meta personal.

Cuenta de ahorro: Contrato entre una institución financiera y un ahorrador en el que la institución financiera guarda nuestros dinero y nos da intereses.

Banco: Institución financiera que recibe nuestros ahorros y presta dinero.

Patrimonio: Conjunto de bienes (casa, animales, terrenos) que pertenecen a una persona o familia.

Cooperativa: Institución financiera que recibe nuestros ahorros y presta dinero.

Institución financiera: Empresa autorizada por el Gobierno para recibir nuestros ahorros: bancos, cooperativas.

Marcadores, Papelógrafo, Hojas en blanco,

Lapices, 20 cartas: 10 con pistas y 10 con respuestas (ahorcado financiero)

\section{Día 1}

\section{Bienvenida:}

Dé la bienvenida a las participantes, confirmando quiénes están presentes o ausentes. Comparta con ellas que el día de hoy van a platicar sobre el ahorro. Explíqueles que escucharán un cuento que les enseñará que el dinero bien gastado puede dar mucho de sí, más de lo que imaginamos, sobre todo si nos ayuda a aprender y mejorar.

\section{Introducción al tema:}

Cuente la historia y mientras lo hace vaya presentando las escenas en el orden adecuado. 


\section{Mapa conceptual}

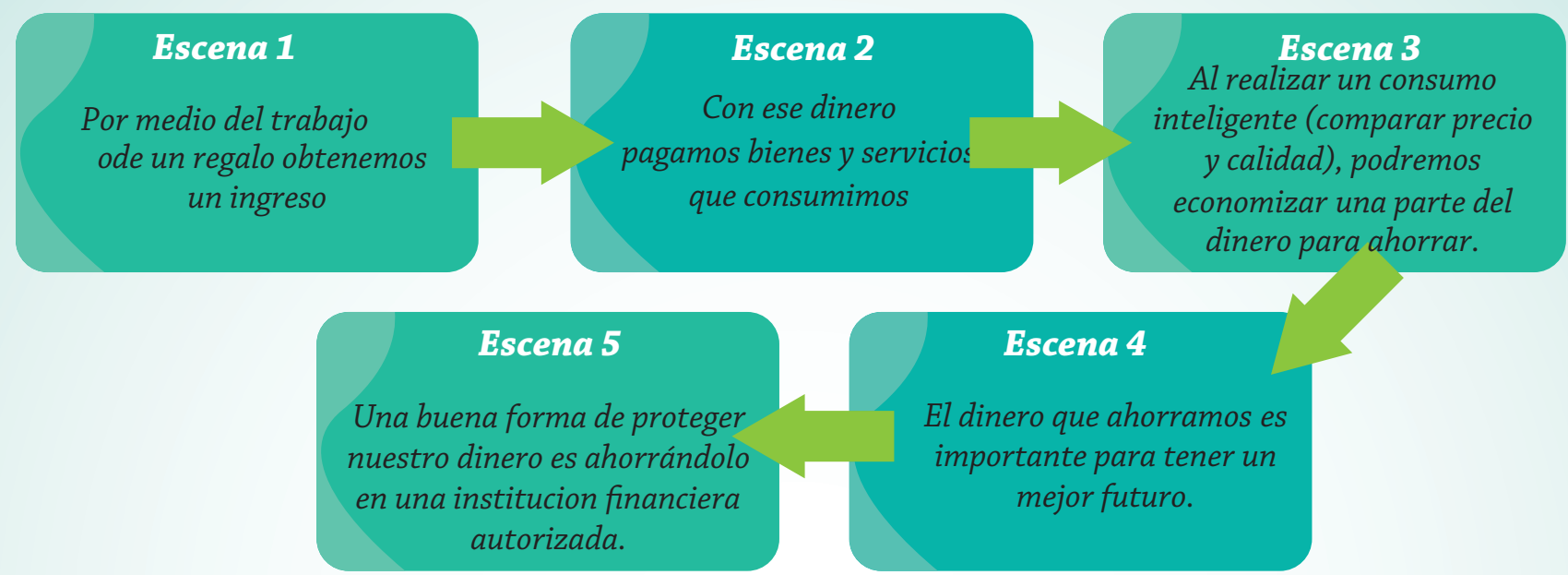

Escena 1: Los abuelos les daban unos centavos a todos los nietos.

Escena 2: Con esos centavos, todos gastaban dinero en la tienda.

Escena 3: Julia guardó el dinero hasta poder comprar un violín.

Escena 4: Julia le pagó al violinista para que le enseñara a tocar el violín.

Escena 5: Julia ahorró su dinero: parte en un banco y parte en una cooperativa.

\section{Cuento: "Las monedas del abuelo"}

Julia y sus primos iban cada mes a la casa de los abuelos y esperaban con ilusión el momento en que su abuelo les daba unos centavos "para que se compraran cualquier cosa". Entonces todos los niños corrían a la tienda a comprar chicles, bolsitas o dulces. Y como vieron abuelos, tíos y padres, que así los niños nunca aprenderían a manejar el dinero, les propusieron una prueba especial y que en el plazo de un año enseñaran a todos que eran capaces de conseguir con aquellos centavitos.

Algunos se propusieron ahorrar, pero Pablo y Manuel, los más chiquitos, no hicieron ni caso, y en cada visita siguieron gastando todo en chucherías. Rosi era una niña muy lista y decidió empezar a manejar su dinero con cambios, comprando y vendiendo cosas. En poco tiempo sorprendió a toda la familia, porque consiguió mucho dinero con poco esfuerzo. Pero Rosi apenas tenía cuidado, cada vez se metía en cosas más arriesgadas, y unos meses después se quedó sin un Quetzal en un mal negocio.

Quedaba Julia quien lo pasó mal el día del concurso, porque aunque tenía un plan muy secreto y estupendo, no había podido ahorrar nada. Cuando estaba a punto de finalizar el segundo año, Julia dio una gran sorpresa a todos al aparecer en casa de los abuelos con un violín y mucho dinero. Aún más impresionante fue oírla tocar, porque lo hacía realmente bien, pero lo que terminó por entusiasmar a todos fue la historia de la pequeña violinista. 
Todos sabían que la niña adoraba el violín, aunque en la familia no podían pagarle el instrumento ni las clases. Así que Julia, cuando conoció a un simpático violinista que tocaba en el parque, le ofreció todas las monedas que le diese su abuelo si le enseñaba a tocar. Aunque era poco dinero, el violinista aceptó encantado al ver la ilusión de la niña, y durante meses le enseñó con alegría. Julia puso tantas ganas e interés, que en poco más de un año el artista le prestó un violín para que pudieran tocar a dúo en el parque. Y tuvieron tanto éxito, que en poco tiempo Julia pudo comprar su propio violín, $y$ aún le sobró bastante dinero que lo ahorró en un banco $y$ en una cooperativa. Toda la familia la ayudó desde entonces a convertirse en una famosísima violinista, y contaban a cuantos conocían la historia.

\section{Pregunte a las participantes:}

¿Quiénes son los personajes del cuento?

¿Cómo consiguieron el dinero?

¿Por qué o cómo crees que el abuelo tenía dinero para regalarles a los nietos?

Explica qué hizo cada personaje con las monedas que les daba el abuelo.

¿Qué quisieron enseñarles los mayores a los niños?

¿Qué hizo Julia?

¿Por qué hizo Julia lo que hizo?

¿Qué piensas del ahorro?

\section{Teorizar y definir:}

Juegue la dinámica del "Ahorcado financiero" / Juego de cartas con pistas y respuestas para que se unan en pareja. Dé la pista y las niñas tendrán 4 oportunidades para dar la respuesta. Al fallar se dibuja el ahorcado en 4 fases: (1) horca, (2) cuerpo, (3) manos y pies y (4) cara.

\begin{tabular}{lc|}
\hline \multicolumn{1}{|c}{ PISTAS } & RESPUESTA \\
\hline Guardar dinero... & Ahorro \\
\hline Dinero que recibes... & Ingreso \\
\hline Gastar menos es... & Economizar \\
\hline Tipo de institución financiera.. & Cooperativa/Banco \\
\hline Guardar... & Ahorrar \\
\hline Casa, animales, terreno.. & Patrimonio \\
\hline Lugar seguro para guardar tu dinero... & Banco \\
Gastar es lo mismo que... & Comprar \\
\hline En el banco, el dinero se guarda en una.. & Cuenta de ahorro \\
\hline Ahorramos para tener mejor... & Futuro \\
\hline
\end{tabular}


Haga con las niñas una lluvia de ideas sobre lugares para tener una cuenta de ahorros. Practiquen en parejas a hacer el siguiente diálogo como si estuviera pidiendo información en un banco.

\section{¿Qué necesito para abrir una cuenta de ahorro? \\ ¿Con cuánto abro una cuenta de ahorro? \\ ¿Cómo saco después el dinero? \\ ¿Qué beneficios tiene tener una cuenta de ahorro? \\ ¿De qué otras formas puedes economizar? \\ Día $2(5.2)$}

\section{Aplicación para la vida:}

Empiece por contarles la historia de Susana.

Susana es una niña de 10 años y vive en la comunidad de Tierra Linda. Aunque solo tiene 10 años ya tiene un sueño grande ser independiente, que su familia tenga todo lo que necesita. Cada semana su mamá le da algunos hilos que le sobran y Susana los ha guardado hasta hacer fajas que ha vendido. El dinero que ha ganado con las ventas, Susana lo ha guardado en una alcancía. "Cuando la alcancía esté llena, voy a abrir una cuenta de ahorro", pensó Susana cuando metió dos Quetzales la semana pasada. Hace unos días, su hermanito tenía fiebre y sus papás necesitaban ajustar el dinero para comprar la medicina para que se mejore. Susana muy orgullosa y cooperadora ofreció el dinero de la alcancía para cubrir la necesidad. "Gracias Susana, qué bueno que has ahorrado pues ahora nos estás ayudando para salir de esta pena”.

Pregunte a las participantes:

¿Cuál es el sueño de Susana?

¿Está haciendo algo Susana para lograr su sueño?

¿Pueden pensar en otras cosas que la gente puede guardar o ahorrar?

¿Cómo le sirve los hilos que su mamá le guarda?

¿Puede ser eso un ejemplo de ahorro?

Anime a las niñas a que piensen en una meta o sueño que quieren lograr. Luego ellas deben pensar en las cosas que podrían guardar o ahorrar para llegar a su meta o sueño. Invite a que algunas comenten sobre las decisiones que tendrían que tomar para ahorrar. Pida que cuenten sobre dónde conocen ellas que se puede ahorrar y para qué se usan los ahorros. Pregunte:

\section{¿Qué es ahorrar? \\ ¿Para qué se puede usar el dinero ahorrado? \\ ¿En qué lugares podemos ahorrar en nuestra comunidad?}

Previamente invite a la sesión a alguna persona representante de un banco o cooperativa cercana la comunidad que explique a las niñas las ventajas y las implicaciones de tener una cuenta de ahorros. Si no hubiera alguien cercano a la comunidad podría invitar a alguien de la comunidad que tenga cuenta de ahorro.

Desarrolle el espacio de conferencia para que la persona comparta con las niñas información acerca de las formas de economizar y ahorro que existen en su comunidad. 


\subsection{Puedo decidir para protegerme}

\section{2 horas}

\section{Al finalizar \\ la sesión las \\ participantes \\ habran...}

- Identificado los conflictos en su comunidad.

- Reconocido su derecho a protegerse y tomar decisiones que les protegen.

- Aprendido pasos para tomar decisiones.

\section{Conceptos Clave}

Conflicto: situación que se presenta cuando hay dos o más intereses que se contradicen.

Decisión: determinación de tomar una medida frente a una situación en la que se tienen varias opciones.

\section{Bienvenida:}

Dé la bienvenida a las participantes, confirmando quiénes están presentes o ausentes. Comparta con ellas que el día de hoy van a platicar sobre los riesgos que encuentran y cómo pueden tomar decisiones que las protegen.

\section{Introducción al tema}

Pida a las participantes que hagan un mapa de conflictos de su comunidad. Las niñas van a reunirse en grupos de cuatro y harán una lista de los problemas que les afectan a ellas en su comunidad. Luego en plenaria pedir que los grupos compartan los problemas mientras la mentora de grupo va marcando en el mapa de la comunidad los lugares en donde se dan estos problemas.

Al finalizar de marcar todos los problemas, pregunte al grupo lo siguiente:

¿Cuáles de estos conflictos les afectan más directamente a ustedes?

¿Cómo les afectan?

¿Qué hacen frente a estos conflictos? 
Juegue con ellas "la sábana de los mil nudos". Presente a las niñas una sábana y dígales que esa sábana representa su vida. Como en todas las vidas la sábana tiene un conflicto (mientras les cuenta haga un nudo a la sábana). Pase la sábana a una primera niña y comente que el tiempo pasó y como no se resolvió el primer problema ahora la sábana tiene dos problemas (pida a la niña que haga un nuevo nudo y lo pase a otra niña). Explique que pasaron algunas semanas y como no se resolvieron los primeros dos problemas se hizo un nuevo, llegando a haber cuatro nudos (indique a la niña con la sábana y que la pase a la siguiente). Siga esta dinámica por unas cinco o seis niñas.

Al terminar presente la sábana a la plenaria y pida que la observen. Pregunte:

¿Cuántos conflictos tiene que resolver ahora la niña?

¿Cuántos tenía que resolver al inicio?

¿Qué hubiera pasado si hubiera empezado a resolver sus conflictos desde el primero?

¿Cómo ven el futuro de la niña si no afronta los problemas y resuelve los conflictos?

\section{Definir y teorizar:}

Explique que un problema no es más que un conflicto y lea la definición de los conceptos claves que se presente en esta sesión. Y que cuando a una se le presenta un conflicto uno puede tomar varios caminos. Lo importante es que se tome una decisión y no se espere a que otra gente le diga a uno qué hay que hacer según los intereses de la otra persona.

Presente un papelógrafo titulado: Para tomar decisiones que me protegen... Diga:

Al surgir un problema, el tomar una decisión nos ayudará a resolver el problema lo mejor posible y protegernos de los riesgos que este puede traer. Pregunte:

¿Qué es una decisión?

¿Qué decisiones han tomado ustedes en su vida?

¿Cómo toman la decisión?

¿Qué hacen para tomar decisiones?

Apunte las respuestas del grupo a esta última pregunta en el papelógrafo. Asegúrese de incluir las siguientes ideas:

-Ver cuál es el problema que enfrento.

- Identificar qué va a pasar si no tomo una decisión que me proteja.

- Pensar en tres opciones de acciones y los resultados de cada una.

- Identificar la opción que me protege mejor y tengo más posibilidades de cumplir.

- Compartir mi decisión con una persona de confianza para que me dé su opinión acerca de mi decisión y fortalezca con consejos. 


\section{Aplicación a la vida:}

Pida que se enumeren del 1 al 4 y formen cuatro grupos según el número que les tocó. A cada grupo entregue una de las historias siguientes. Cada equipo debe leer la situación que le tocó e identificar:

¿Qué riesgo está pasando la niña?

¿Qué pasará si la niña no toma una decisión para protegerse?

¿Qué opciones de acciones tiene la niña para buscar su protección? ¿Qué opción le protege mejor y tiene más posibilidad de cumplir? ¿Qué consejo le

daría sobre la decisión que tomó?

Al cabo de 15 minutos, lo presentan, puede ser en dramatización o solamente compartiendo. El resto de las participantes puede aportar a las soluciones propuestas por sus compañeras. Al finalizar pregunte:

¿Qué nuevos conflictos pueden surgir de estas historias si no los confrontan y resuelven?

¿Qué oportunidades pueden aprovechar al tomar decisiones?

¿Cuál de estos conflictos creen que les podrá tocar a ustedes?

¿Qué sería lo más difícil de confrontarlo?

¿Qué pasaría con sus vidas si no lo confrontan?

¿Qué opciones de acciones tendrían para tomar?

¿Qué decisión/acción les protegerá mejor?

\section{HISTORIAS}

1. Tengo 14 años y mis padres dicen que mejor ya no voy a estudiar, porque no puedo aprender nada y es un gasto de dinero y tiempo. Yo saco buenas notas y sueño con ir a la universidad para ser enfermera.

2. Ya estoy en básicos, sigo estudiando a pesar de que mis papás no querían. Mis notas son buenas para graduarme pronto de Bachiller. Cuando le dije a mi familia que quiero ir a la universidad me dicen que no hay manera porque no tienen dinero. Averigüe sobre la posibilidad de una beca de trabajo. ¿Qué hago?

3. Empecé la universidad, vivo lejos de mi casa y tengo poco dinero. Mi novio, me dijo estúpida por seguir con mi sueño y piensa que no voy a salir adelante. Casi no me puedo concentrar por todo lo que me dice, tal vez tiene razón. ¿Qué hago?

4. Estoy en líos. Estoy embarazada pero no casada. Lo bueno es que estoy a punto de terminar la universidad y graduarme de enfermera. No tengo dinero para este bebé y no creo que quiero seguir con mi novio. 


\subsection{Cambiando la violencia por el respeto} entre hombres y mujeres

\section{2 horas}
Al finalizar
- Reconocido los diferentes tipos de violencia que existen y cómo se dan en la comunidad.
la sesión las
- Identificado formas de comportamiento que son violentas porque afectan negativamente la dignidad
participantes
$y$ libertad de otras personas.
habran...
- Conocido la ley para prevenir, sancionar y erradicar la violencia intrafamiliar.

\section{Conceptos Clave}

\section{Violencia:}

Son aquellas acciones que van en contra de la dignidad de una persona, limita su libertad y posibilidades de crecimiento y

desarrollo.

Violencia Intrafamiliar:

Es la que comete un miembro de la familia en contra de otro, especialmente cuando viven en una misma casa

Tipos de violencia:

La violencia se puede practicar de diferentes formas como física, psicológica, económica y sexual.

Folletos con la ley para cada niña Papelógrafos Marcadores $\cdot$ Hoja de trabajo

\section{Bienvenida:}

Dé la bienvenida a las participantes, confirmando quiénes están presentes o ausentes. Comparta con ellas que el día de hoy van a trabajar sobre el tema de la violencia, especialmente en contra de la mujer y van a conocer los lugares a donde se puede pedir ayuda.

\section{Introducción al tema:}

Harán dramatizaciones del tipo de relaciones que hay en la comunidad que no les gustan, pues sienten que les afectan y no permiten que se desarrollen y sea felices. Para eso divida a las participantes en cuatro grupos y asigne a cada grupo un espacio de la comunidad (casa, escuela, campo de juegos, campo/ siembras).

Diga a los participantes:

En los módulos previos hemos trabajado sobre la importancia de las relaciones y las ideas de cómo comportarnos unos con otros y otras. Hoy quiero que ustedes sean reporteros de la prensa local y denuncien en nuestro pequeño periódico comunitario algunas relaciones que se dan que no les gustan porque les hacen sentir incómodas cuando las ven y saben que alguna de las personas está saliendo afectada negativamente, no se siente feliz y no se desarrolla. 
El grupo uno va dramatizar alguna relación de este tipo que se da en la escuela, el dos una que se da en la casa, el tres una que se da en el campo de juego y el cuatro uno que se da en las siembras. Pueden jugar a que son reporteras investigando la noticia o bien que están presentes en el lugar. Sean creativas, lo importante es dar a conocer qué relaciones provocan que las niñas no se sientan felices porque no pueden desarrollarse y ven limitada su libertad.

Dé al grupo 30 minutos para prepararse, tendrán en primera instancia que decidir qué van a dramatizar y luego preparar la dramatización. Mientras los grupos trabajan circule entre ellos viendo qué es lo que han preparado y ayudándoles a buscar ejemplos que sean representativos de la violencia, recuerde que hay muchas formas de violencia.

Al pasar el tiempo suficiente pídales reunirse todas nuevamente y ver lo que cada grupo está listo para presentar. Luego de cada presentación pregunte a la plenaria lo siguiente, apuntando en un papelógrafo sus respuestas.

¿Qué acción violenta es la que se da?

¿Entre qué personas se da?

¿Quién sale más afectada?

¿Cómo?

¿Hay otros/as afectados/as?

\section{Definir y teorizar:}

\section{Explique a la plenaria:}

Los ejemplos que mostraron son formas de violencia que nos parecen "normales" porque son parte del trato entre personas de la comunidad. Sin embargo el Estado de Guatemala, o sea todos los representantes del país, han pensado que esto no es aceptable y han sacado leyes para proteger especialmente a mujeres, jóvenes, niños y niñas de la violencia que pueden vivir en su comunidad. Hoy vamos a conocer una de esas leyes: La Ley de prevención, sanción y erradicación de la Violencia Intrafamiliar.

Entregue a cada niña un folleto de la ley, permítales hojear el folleto completo, viendo qué otras leyes tiene el folleto; comentando qué artículos les llaman la atención; cuáles ya sabían que eran sus derechos y cuáles no. Explique que se van a centrar en la ley que trata la Violencia Intrafamiliar y pida que compartan qué situaciones conocen ellas que se dan en su comunidad o comunidades cercanas de Violencia Intrafamiliar.

Empiece por leer la Ley y deténgase en el artículo que habla de los tipos de violencia. Lleve un papelógrafo con el nombre de cada tipo de violencia y un ejemplo de ese tipo de violencia. Pida que den ejemplos de estos tipos de violencia en su comunidad y expliquen cómo estos ejemplos les afectan. Siga leyendo la ley, de forma lenta y pausada explicando qué significan los artículos. No es necesario que termine en esta sesión. Deben llegar hasta el Artículo 3 que establece quiénes pueden denunciar la Violencia Intrafamiliar. Poniendo especial atención en que ellas tienen el derecho de poner denuncias y de cambiar las relaciones a partir de esta ley. 


\section{Aplicación para la vida:}

Pida que en la hoja de trabajo "Cambiando la violencia por el respeto" de forma individual dibujen una forma en que han sido víctimas de violencia por parte de alguien de su familia, puede ser su mamá, su papá, hermanas, hermanos, primas, primos, abuelitos etc. Recordando que un acto violento es aquel que afecta negativamente a una persona, la hace sentirse triste, no le permite desarrollarse.

Luego pídales que escriban qué podrían hacer momentos antes de que se dé el hecho violento para evitarlo, protegerse y asegurarse que no vuelve a pasar.

Al finalizar permita que de forma totalmente voluntaria compartan sus trabajos. Ayuda si usted se anima y da un ejemplo propio de su vida primero.

\section{Cambiando la violencia por el respeto}

Dibuja alguna forma en que has sufrido de violencia por parte de alguien que conoces. Recuerda que un acto violento es aquel que afecta negativamente a una persona, la hace sentirse triste, no le permite desarrollarse.

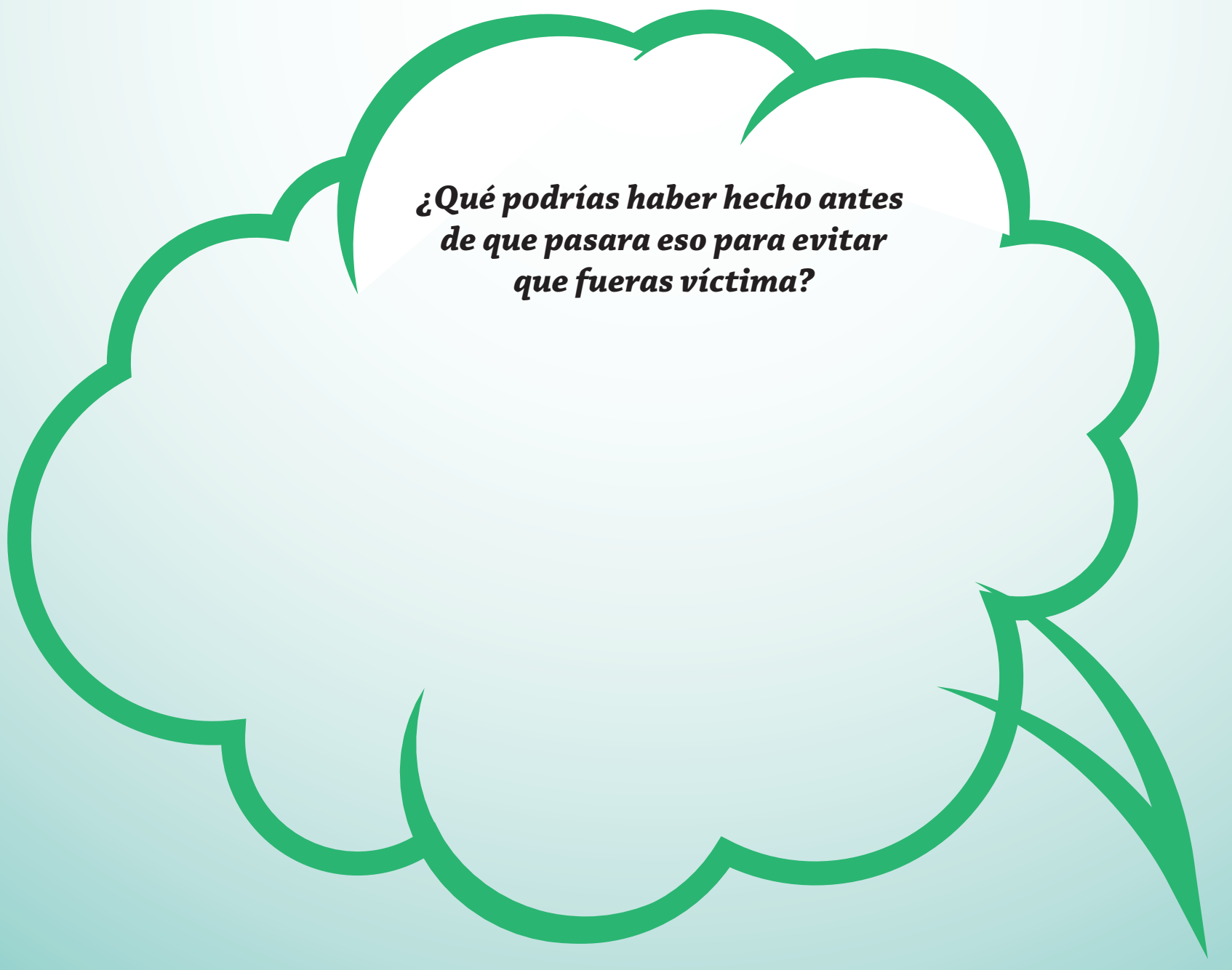




\section{Al finalizar \\ la sesión las \\ participantes \\ habran... \\ - Reflexionado sobre sus derechos con actitudes de solidaridad, justicia, equidad y responsabilidad. \\ - Comprendido la función de los impuestos. \\ - Identificado en qué momento están pagando impuestos.}

\section{Conceptos Clave}

SAT (Superintendencia de Administración Tributaria) - Recauda y administra los impuestos que el Estado recibe.

Estado Conjunto del territorio, población y de instituciones de un país encargadas de la administración, justicia, seguridad.

Impuestos: Aportes que deben hacer las personas y las empresas, obligados por ley, para que el Estado tenga los recursos suficientes para brindar los bienes y servicios públicos que necesita la comunidad. Cuando son bien recaudados y

administrados ayudan a redistribuir la riqueza de un país entre su población.

\section{Hojas en blanco $\cdot$ Periódicos · Tijeras Goma $\cdot$ Rótulos con los conceptos clave $\cdot$ Hoja de lectura}

\section{Bienvenida:}

Dé la bienvenida a las participantes, confirmando quiénes están presentes o ausentes. Comparta con ellas que el día de hoy van a aprender sobre derechos y obligaciones y realizarán un paseo por su comunidad para identificar los servicios públicos y servidores públicos.

\section{Introducción al tema:}

\section{Objetivo: Identificar los servicios públicos.}

Información para la mentora de grupo con el fin que pueda llevar a cabo la dinámica:

En la comunidad pueden identificarse los siguientes servicios públicos: alumbrado público, servicio de alcantarillado (desagües), agua potable (pilas comunales), caminos adoquinados o asfaltados, estación de policía o de bomberos, puesto de salud, escuela, entre otros.

El alumbrado público es un servicio y la empresa que lo provee cobra por ese servicio. Los focos que están en la calle son pagados por las personas que pagan impuestos. Con el dinero de nuestros impuestos, el municipio paga: el alumbrado público, la pavimentación de las calles, la recolección de basura, la vigilancia de los policías... Todos estos son servicios públicos que nos benefician a todos y los pagamos entre todos. El gobierno reúne el dinero y lo administra, pero quienes aportamos los recursos para pagar los servicios públicos somos los ciudadanos y todas las empresas a través de los impuestos. En el país se lleva un presupuesto que propone el Ministerio de Finanzas, pero luego aprueba el Congreso y la SAT es la encargada de recaudar los impuestos. 
Instrucciones: Salga con el grupo de jóvenes del lugar de reunión y den un paseo por la comunidad con el fin de que todas -durante el paseo- vayan identificando los diferentes servicios públicos que existen. Pueden entrar a la municipalidad o al puesto de salud o a la oficina de la escuela y preguntarle a los servidores públicos:

\section{(1) ¿quién paga su salario? y (2) ¿quién manda los recursos para que funcione ese lugar?}

Pregunte a las participantes:

¿Han escuchado a alguien hablar sobre los impuestos, su pago y los usos?

Si crees que a tu comunidad le falta algo, ¿crees que podría solucionarse con dinero del Estado?

\section{Teorizar y definir:}

Lea con las participantes la hoja de lectura, mientras leen subraye con ellas las ideas claves y la información más relevante sobre el estado y los impuestos.

Realice la dinámica: ¡Periódicos! La noticia de hoy. Pida que formen parejas para recortar y pegar titulares o artículos de prensa donde aparezcan acciones que hace el Estado que muestran en qué se invierten los impuestos. Es muy importante que estudie este material antes de la sesión y se asegure que los conceptos claves son aprendidos por las participantes.

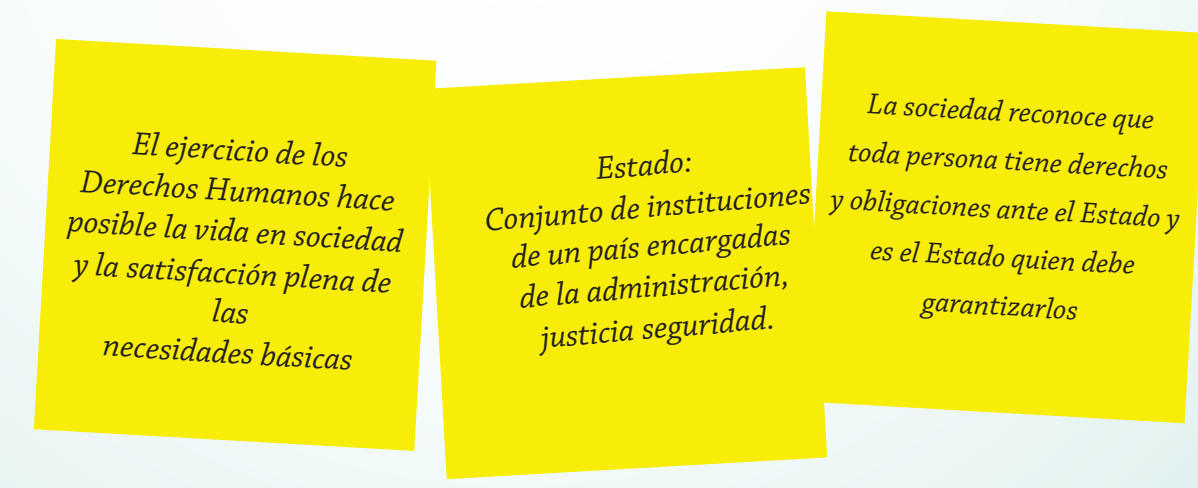

\begin{tabular}{cc}
\hline Factura: & Impuestos: \\
Comprobante de & Aportes que deben hacer \\
las personas y empresas, \\
obligados por ley, para que \\
una comprahecha & el Estado tenga los \\
y de recaudación & recursos \\
de impuestos & suficientes para brindar \\
& los bienes y servicios \\
& públicos que necesita la \\
& comunidad.
\end{tabular}

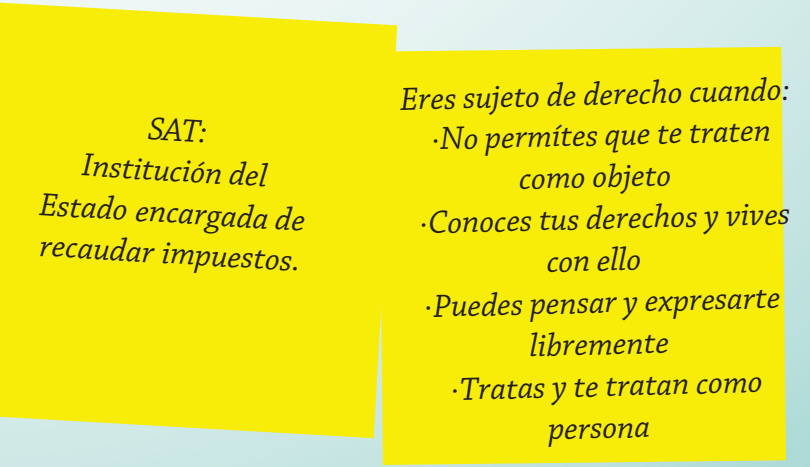




\title{
4. Aplicación a la vida:
}

Pregunte a las participantes:

\author{
¿En qué momentos pagas impuestos? \\ ¿Qué piensas sobre el uso de los impuestos que tú y tu familia pagan? \\ ¿Qué cambiarías del uso de los impuestos en tu comunidad?
}

\section{Hoja de lectura}

\section{El Estado de Guatemala, los impuestos y nuestros derechos}

El Estado de Guatemala está compuesto por toda la población y es como una familia en la que cada miembro está encargado de una actividad. El gobierno es una parte del Estado. Los miembros del gobierno son los ministerios de educación, salud, el ejército, la defensoría de la mujer indígena, las escuelas, los centros de salud, la policía, los juzgados, las oficinas de la SAT. El Estado de Guatemala, es decir todos los miembros de la familia del Estado, son los encargados de velar que tus derechos sean respetados.

¿Cómo el Estado garantiza mis derechos? Por ejemplo cuando el Estado construye una escuela y le paga a la maestra, está garantizando tu derecho a la educación. Cuando el Estado construye un puesto de salud y a ti te atiende el doctor y te proporciona las medicinas, está garantizando tu derecho a la salud. Los bienes y servicios que proporciona el Estado son llamados bienes públicos y todos y todas tienen derecho a usarlo, nadie puede ser excluido o discriminado de usarlo. La cantidad y la calidad de los bienes y servicios públicos no pueden ser disminuidas por el hecho de que muchas personas los estén consumiendo al mismo tiempo.

Pero ¿de dónde saca dinero el Estado? ¿Recuerdas cuando aprendiste a hacer tu presupuesto? El Estado hace su presupuesto todos los años. Sus ingresos son los impuestos y sus gastos son construcción de carreteras, pago de empleados, construcción de escuelas, hospitales, pago de policías, pago del alumbrado público, etc.

Ahora platiquemos de los impuestos. Los impuestos son aportes que deben hacer las personas y las empresas, obligados por ley, para que el Estado tenga los recursos suficientes para brindar los bienes y servicios públicos que necesita la comunidad.

Los impuestos son importantes porque:

- el Estado puede obtener los recursos para poder brindar educación, salud, seguridad, justicia, obras públicas y apoyo a los más necesitados, entre varias cosas más,

- $\quad$ se puede conseguir más igualdad de oportunidades,

- $\quad$ es un acto de solidaridad al contribuir con el bienestar de los demás,

- es una forma de participar en los asuntos de la comunidad,

- en ellos también se refleja lo que queremos como sociedad. 
Al pedir el comprobante en cada compra que hacemos, estamos colaborando en la recaudación de los impuestos.

Los comprobantes son las facturas cuando compramos al contado o al crédito. Por ejemplo, cuando realizamos una compra nos cobran el valor de la mercadería más el IVA y nos entregan una factura por el total a pagar. El IVA que nos cobran debe ser pagado por el comerciante al Estado, a través de la SAT.

Los comprobantes son muy importantes porque:

- son documentos legales que establecen la relación entre el comprador y el vendedor, - prueban que las operaciones se realizaron y proporcionan un detalle de las mismas, - son el respaldo para registrar en la empresa las operaciones que se realizaron, - permiten realizar un control posterior de la operación por parte de la SAT.

De esa manera se puede saber si los impuestos que pagó la empresa coinciden con los que se originaron en sus operaciones.

Pedir la factura es un derecho que tenemos todos los que hacemos una compra y una obligación o responsabilidad del vendedor.

\footnotetext{
Diga: ¿Sabes que todos los y las guatemaltecas pagamos impuestos? Además del Impuesto al Valor Agregado IVA (12\% del valor de un producto o servicio) también existen otros impuestos. Las empresas o personas que emiten factura por un servicio deben pagar el Impuesto Sobre la Renta ISR (5\% del valor facturado).

Algunas empresas en lugar de pagarle el ISR a la SAT para que el gobierno haga obras públicas, tienen Fundaciones que hacen proyectos de beneficio social como construcción de escuelas, implementación de agua potable en comunidades. Es decir que la Fundación de la empresa hace obras públicas directamente, en lugar de darle el dinero al gobierno para que éste las haga.
} 
Al finalizar

la sesión las

participantes

habran...
- Comprendido qué es el crédito y cuáles son los beneficios de usarlo correctamente así como los riesgos del mal uso del crédito.

- Aprendido a calcular su capacidad de pago.

- Aplicado el concepto de intereses.

\section{Conceptos Clave}

Crédito: Préstamo que se tiene que pagar con intereses en un plazo determinado.

Capacidad de pago: cantidad disponible de nuestros ingresos después de restar todos nuestros gastos. Historial

crediticio: registro de los créditos que hemos solicitado, cómo y cuándo los hemos pagado. Tasa de interés:

Porcentaje que debemos pagar, adicional a la cantidad que nos prestaron. El crédito es más caro si la tasa de interés

es alta.

Tarjeta de crédito: Se usa para comprar algo que se paga con el dinero del Banco. Si la compra no se paga en la fecha que el Banco lo exige, se paga la cantidad que costó la compra más intereses.

Déficit: Cuando gastamos más de lo que recibimos.

Superávit: Cuando gastamos menos de lo que recibimos y nos sobra dinero.

Papelógrafos con los ejemplos de presupuesto de la familia Yat y la familia Choc.

Papeles para sortear qué familia corresponde Rompecabezas de los conceptos clave

Hojas en blanco

\section{Bienvenida:}

Dé la bienvenida a las participantes, confirmando quiénes están presentes o ausentes. Comparta con ellas que el día de hoy van a aprender sobre el funcionamiento del crédito.

\section{Introducción del tema:}

Lea la siguiente historia a las participantes.

Una tarde, doña Natalia estaba caminando en la calle principal con su hija Sonia, cuando pasaron frente a una tienda de artículos para el hogar:

-Mamá, jmira! ahí está la sala que querías y está en oferta, en seis pagos pagándola con tarjeta de crédito. ¿La compramos con tu tarjeta? En ella tienes mucho dinero — dijo Sonia.

- No, la tarjeta de crédito no es mi dinero: es un préstamo del Banco que tengo que pagar con intereses —respondió la mamá.

— ¿Intereses? - preguntó Sonia.

-Interés es el dinero que el Banco me cobra por prestarme a través de la tarjeta.

-A ver, no me confundas... ¿te alcanza para la sala o no? 
- Lo importante es saber si podemos pagar esa deuda...

-Pero si yo escuché muy claro que le decías a mi papá que con un crédito podríamos comprar hasta una casa... ¿Cómo no vamos a poder comprar la sala?

-Así empiezan los problemas, Sonia: si compramos muchas cosas y nos pasamos, lo que nuestros ingresos nos permiten, después no podremos pagar — dijo doña Natalia.

— ¿Y qué? De todos modos, ya tendríamos la sala...

-No es tan sencillo. Es como cuando la tía Eugenia pidió prestado a todos y luego no pagó, ¿recuerdas?

-Huy, sí: ya nadie le presta. Hasta los abuelitos se esconden de ella. Comienzo a entender...pero ¿vamos a desaprovechar la promoción? Dice ahí que está a 6 meses sin intereses, ¿eso quiere decir que el Banco no te va a cobrar por prestarte?

- Sí. Pero si no pagamos una de las mensualidades, sí tendríamos que pagar intereses.

Por eso, antes de comprar la sala hay que ir a la casa, calcular con papel y lápiz nuestra capacidad de pago.

- Ay mama, yo quiero una tarjeta de crédito; así podría comprar muchas cosas —insistió Sonia.

-No, el crédito es un préstamo que debes pagar, por eso implica responsabilidad.

Podrás tener una tarjeta cuando seas mayor de edad y tengas un ingreso por tu trabajo que te permita pagar lo que compres.

Pregunte a las participantes:

$$
\begin{gathered}
\text { ¿Para qué sirve el crédito? } \\
\text { ¿Es malo pedir dinero prestado? }
\end{gathered}
$$

¿Qué pasa si pedimos prestado dinero y después ya no pagamos?

¿Qué quiere decir "capacidad de pago"?

\section{Teorizar y definir}

Escriba cada concepto clave en una hoja y córtelos de manera que se formen rompecabezas. Forme siete grupos y entregue un rompecabezas a cada grupo. Pida que armen los rompecabezas y los peguen en una hoja blanca. Luego solicite que cada grupo presente el concepto que le tocó. 

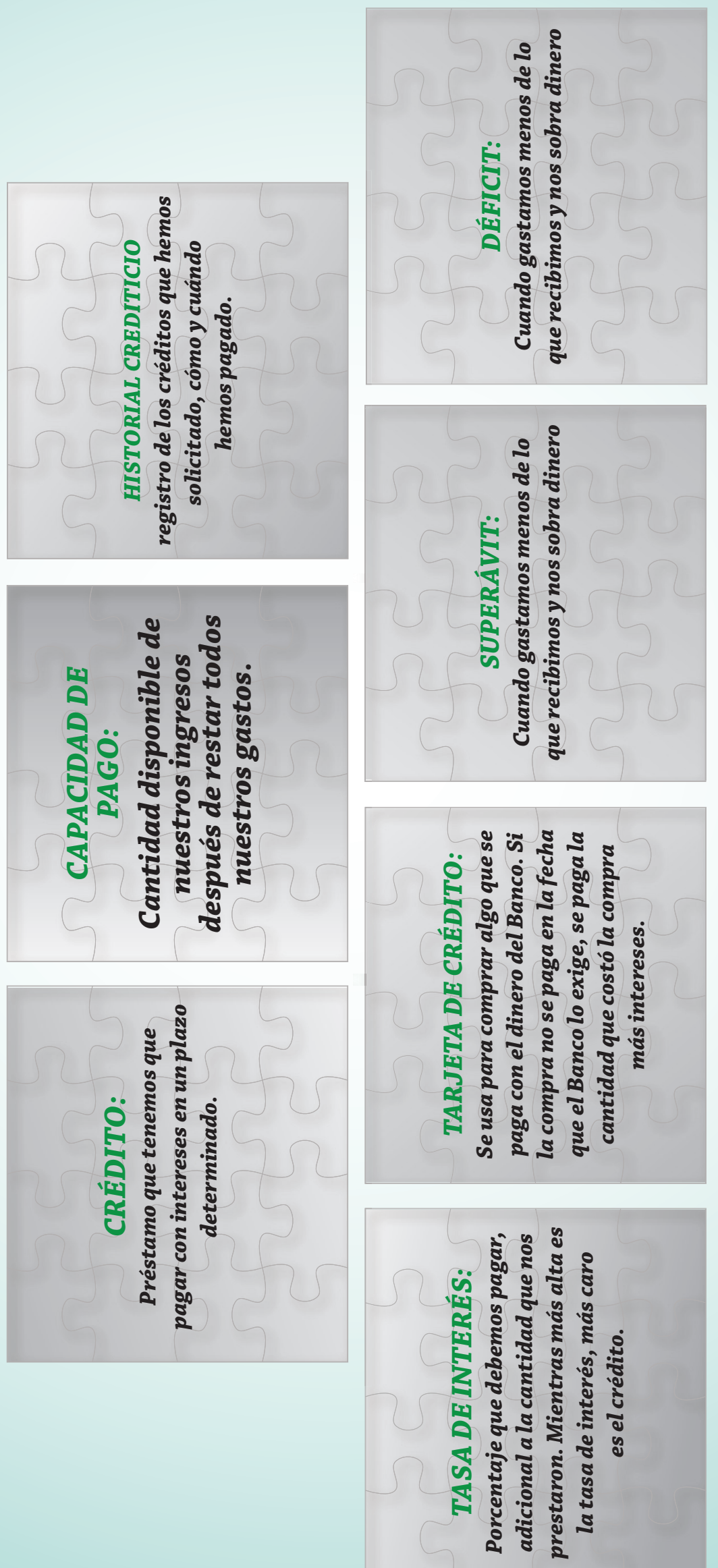


\section{Cuando ya pasaron todos los grupos explique a las participantes:}

El crédito es una cantidad de dinero que recibimos con la obligación de pagarla en un plazo determinado más otra cantidad por concepto de intereses. Se trata de una herramienta que nos permite adquirir bienes y servicios, algunos de los cuales no podríamos adquirir en poco tiempo sin un crédito. Por ejemplo: es más fácil comprar una casa a crédito que de contado, pues tendríamos que ahorrar por mucho tiempo para comprarla en un solo pago. Pero los créditos también pueden meternos en problemas si somos irresponsables con su uso: si adquirimos créditos que no podemos pagar, o si no pagamos a tiempo, nuestras finanzas se verán afectadas y nos cerraremos las puertas para obtener nuevos créditos en el futuro.

Antes de solicitar un crédito, debemos evaluar si podemos pagarlo. Para eso necesitamos saber qué parte de nuestros ingresos podemos destinar al pago del crédito, es decir, nuestra capacidad de pago. Podemos conocer nuestra capaci-dad de pago restando nuestros gastos a nuestros ingresos, incluyendo las cantidades destinadas a pagar otras deudas y al ahorro. Lo que nos quede será la cantidad máxima que podemos destinar al pago de nuevas deudas sin riesgo de incumplir con los pagos.

Así como comparamos precios al comprar una televisión, al contratar un crédito es conveniente comparar distintas opciones. El precio de un crédito es su tasa de interés. Ésta es el dinero que debemos pagar por recibir un crédito, y es adicional a la cantidad que nos prestaron. Cuanto más alta sea la tasa de interés, más caro será el crédito. Antes de contratar un crédito es importante analizar varias opciones e identificar cuál nos cobra menos intereses. La forma en que pagamos nuestros créditos queda registrada: si lo hacemos puntualmente, nos retrasamos o no pagamos. A ese registro se le conoce como historial crediticio. Si es bueno nos abrirá las puertas a futuros créditos; en cambio, un mal historial nos cerrará las puertas, pues nadie presta a quien no paga.

Existen diferentes tipos de crédito. Al préstamo que pedimos para invertir, es decir, para iniciar o hacer crecer un negocio, se le llama crédito empresarial. Un crédito empresarial nos permite, por ejemplo, comprar productos para abrir una tienda de abarrotes o comprar un taxi.

El crédito a la vivienda o hipotecario nos permite adquirir una casa o terreno y pagarlo poco a poco, pues -como ya aprendimos- es más fácil adquirir una casa de esta forma que comprarla en un solo pago. Cuando destinamos el crédito a comprar bienes y servicios que servirán para satisfacer nuestras necesidades cotidianas, hablamos de crédito al consumo.

Un instrumento de crédito muy utilizado es la tarjeta de crédito, que es un medio de pago: con ella podemos realizar compras en establecimientos comerciales sin cargar efectivo. Cuando contratamos una tarjeta de crédito, el Banco nos presta hasta una determinada cantidad, llamada línea de crédito. Si disponemos de ese dinero, tendremos que pagarlo, más los intereses correspondientes. Es muy importante no confundir la tarjeta de crédito con la tarjeta de débito: al utilizar esta última hacemos uso de nuestro dinero, que guardamos en una cuenta de ahorro o de cheques. Con esa tarjeta podemos retirar nuestro dinero o comprar bienes y servicios.

\section{Aplicación para la vida:}

Pregunte a las jóvenes si han escuchado a sus familiares comentar sobre algún préstamo o crédito y que com-partan su uso y si alguna vez han estado en dificultades para pagarlo. Permita que compartan casos que conocen.

Pida que se unan por parejas y sortee entre las parejas si son la familia Yat o la familia Choc. Presente los papelógrafos con el ejemplo de presupuesto de cada familia. 


\section{Presupuesto de la Familia Choc}

\begin{tabular}{l|l|l|l|l|l} 
& Semana 1 & Semana 2 & Semana 3 & Semana 4 & TOTAL DEL MES \\
\hline INGRESOS & $\mathbf{Q 7 0 0 . 0 0}$ & $\mathbf{Q 7 0 0 . 0 0}$ & $\mathbf{Q 7 0 0 . 0 0}$ & $\mathbf{Q 7 0 0 . 0 0}$ & $\mathbf{Q} 2,800.00$ \\
\hline GASTOS & $\mathbf{Q} 600.00$ & $\mathbf{Q} 520.00$ & $\mathbf{Q} 630.00$ & $\mathbf{Q} 580.00$ & $\mathbf{Q} 2,330.00$ \\
\hline $\begin{array}{l}\text { Tienen un } \\
\text { súperavit. } \\
\begin{array}{l}\text { Si les alcanza } \\
\text { el dinero }\end{array}\end{array}$ & $\mathbf{Q 1 0 0 . 0 0}$ & $\mathbf{Q 1 8 0 . 0 0}$ & $\mathbf{Q 7 0 . 0 0}$ & $\mathbf{Q 1 2 0 . 0 0}$ & $\mathbf{Q} 470.00$ \\
\hline
\end{tabular}

\section{Presupuesto de la Familia Yat}

\begin{tabular}{l|c|c|c|c|c} 
& Semana 1 & Semana 2 & Semana 3 & Semana 4 & TOTAL DEL MES \\
\hline INGRESOS & Q700.00 & Q700.00 & Q700.00 & Q700.00 & Q 2,800.00 \\
\hline GASTOS & $Q 850.00$ & $Q 725.00$ & $Q 775.00$ & $Q 710.00$ & $Q 3,060.00$ \\
\hline $\begin{array}{l}\text { Tienen un } \\
\text { déficit. } \\
\begin{array}{l}\text { No les alcanza } \\
\text { el dinero }\end{array}\end{array}$ & Q150.00 & $Q 25.00$ & $Q 75.00$ & $Q 10.00$ & $Q 260.00$ \\
\hline
\end{tabular}

Pida que según la familia que les tocó ser, contesten las siguientes preguntas:

1. ¿Hay superávit o déficit?

2. ¿En qué gastos podría reducirse para que se dé un equilibrio?

3. ¿Cuánto dinero puede ahorrar al mes?

4. ¿ ¿Tiene la familia la capacidad de pedir un crédito?

Al terminar solicite que se junten en grupos de cuatro, de manera que quede una pareja de cada familia. En todos los grupos debe haber una familia Yat y una familia Choc. En sus grupos van a compartir sus respuestas y sacar conclusiones sobre el crédito... ¿Qué beneficios tiene?¿Qué retos implica?

Luego de que han discutido en sus cuartetos solicite que regresen a plenaria y pida que algunos grupos compartan las conclusiones a las que llegaron. 


\subsection{Vencemos obstáculos en esta comunidad}

\section{2 horas}

\section{Al finalizar \\ - Identificado los conflictos en su comunidad. \\ la sesión las \\ participantes \\ habran... \\ - Reconocido el conflicto como una oportunidad para mejorar una situación. \\ - Aprendido estrategias de resolución de conflictos y de negociación.}

\section{Conceptos Clave}

\section{Conflicto:}

Situación que se presenta cuando hay dos o más intereses que se confrontan.

Resolución de conflictos:

Capacidad humana de dar respuesta a las situaciones conflictivas que surgen.

\section{Bienvenida:}

De la bienvenida a las participantes, tomando nota de quiénes están ausentes y quiénes están presentes. Pida que comenten un poco sobre alguna buena experiencia que han tenido resolviendo un problema recientemente.

\section{Introducción al tema:}

Pida a las participantes que hagan un mapa de conflictos de su comunidad. Van a reunirse en grupos de cuatro, entregue a cada uno un papelógrafo con el mapa de la comunidad y pídales que dibujen en dónde se dan conflic_ tos y qué conflictos son. Pídales que piensen en conflictos familiares, en la escuela, en la municipalidad, oficinas auxiliares de instituciones de Gobierno, en las calles, en el mercado, en el banco, en el campo etc. Luego de unos 20 minutos pídales que regresen y presenten sus mapas, mientras usted escribe en otro papelógrafo los conflictos que surgen en la comunidad. 
Explique que los conflictos son reales y se han dado siempre. Repase cada conflicto con ellas y trate de abarcar lo más que pueda para conocer los conflictos. Puede preguntar:

¿Desde cuándo se da el conflicto?

¿Qué lo originó?

¿Quiénes están involucradas en el conflicto?

¿Quiénes son afectadas por el conflicto?

¿Cómo afecta el conflicto a toda la comunidad?

¿Han tratado de solucionar el conflicto alguna vez?¿Cómo?¿Qué pasó?

Escojan uno de los conflictos que más tiempo tiene de existir en la comunidad y Juegue "La sábana de los mil nudos". Tome una sábana o un pedazo de tela largo y dígale a las participantes que esa sábana representa el tiempo y por cada vez que el conflicto se empeoró van a ir haciendo un nudo en la sábana. Todas deben tratar de recordar juntas qué fue lo que inició el conflicto. El propósito es demostrar cómo si un conflicto no se resuelve solamente genera nuevos problemas. Diga:

Vamos a hacer el ejercicio con el conflicto que escogimos, que lleva mucho tiempo de estar y todas conocemos un poco de su historia. Pero vamos a empezar desde hoy.

¿Cuál es el resultado que vemos hoy del conflicto? Haga un nudo en el final de la sábana.

¿Qué provocó lo que está pasando hoy? Haga un nudo un poco antes del nudo que ya hizo.

¿Esa situación fue provocada por qué? Haga un nudo un poco antes del nudo que ya hizo. Siga así

hasta llegar lo más cercano al inicio del conflicto y que la sábana tenga muchos nudos.

¿Qué hubiera pasado hoy si el conflicto se hubiera resuelto en un inicio?

¿Qué pasa cuando no nos atrevemos a resolver conflictos?

¿Qué pasa cuando sí nos atrevemos a resolver conflictos?

\section{Teorizar y definir:}

Pida a las participantes que traduzcan los conceptos claves a su idioma materno. Luego discutan qué estrategias hay para resolver conflictos y cuáles son las que más se usan en su comunidad.

Realice la dinámica "Dando y Dando" para ver que hay formas de resolver conflictos y sobre todo que la solución de los conflictos puede aportar a que se respeten los derechos humanos. Diga:

Para que las personas puedan resolver conflictos y gozar de sus derechos lo más posible sin afectar los derechos de otras personas, muchas veces es necesario negociar. La negociación es cuando dos o más personas quieren cosas diferentes y hablan para llegar a un acuerdo de qué hacer para encontrar una solución que convenga a todos. Para eso cada persona debe tener ciertas actitudes. Ustedes han negociado cuando regatean al comprar algo, o cuando consiguen que les den permiso. 
¿Qué debe hacer una persona al negociar? Apunte en un papelógrafo las respuestas que incluya:

1. Escuchar lo que dicen los otros, lo que piden.

2. Respetar su opinión.

3. Comprender que no siempre se va a conseguir todo tal como uno lo quiere.

4. Dar o hacer algo, a cambio que la otra persona también dé o haga algo.

Pida que den ejemplos de cuándo han hecho negociaciones y que expliquen por qué una negociación se dice que es una situación "Gana-Gana”.

Pida que se enumeren del 1 al 4 y formen cuatro grupos según el número que les tocó. A cada grupo asigne una de las historias de la Hoja de Trabajo "Venciendo Obstáculos”. Cada equipo debe leer la situación que le tocó e identificar:

¿Qué derecho/s está siendo puesto en riesgo?

¿Qué quiere cada parte del conflicto?

¿Cómo puede negociar la mujer en el conflicto?

¿Qué debe pedir/ceder con la contraparte?

\section{Aplicación para la vida}

Al cabo de 15 minutos, lo presentan, puede ser en dramatización o solamente compartiendo. El resto de las participantes puede aportar a las soluciones propuestas por sus compañeras. Al finalizar pregunte:

¿¿Qué nuevos conflictos pueden surgir de estas historias si no los confrontan y resuelven?

¿¿Qué oportunidades pueden salir de la negociación en estos conflictos?

¿¿Cuál de estos conflictos creen que les podrá tocar a ustedes?

¿¿Qué sería lo más difícil de confrontarlo?

¿¿Qué pasaría con sus vidas si no lo confrontan?

•¿Cómo harían la negociación?

Pida que completen la hoja de trabajo: "Venciendo Obstáculos II". 


\section{Venciendo obstáculos}

Tengo 14 años y mis padres dicen que mejor ya no voy a estudiar, porque no puedo aprender nada y es un gasto de dinero y tiempo. Yo saco buenas notas y sueño con ir a la universidad para ser enfermera. Ahora que empieza la cosecha del cardamomo me van a obligar a ir a eso y no me gusta por las cosas que pasan allí.

Ahora estoy en la universidad $y$ sufriendo con poco dinero.

Mi novio me llamó estúpida por seguir mi sueño y me dijo que no piensa que voy a salir adelante. Casi no puedo concentrarme por escuchar todo lo que me dice. Talvez tiene razón. ¿Qué hago?
Después de un tiempo todavía estoy estudiando. Sigo sacando buenas notas, y pronto voy a salir de bachiller.

Dije a mi familia que querría estudiar en la universidad, pero ellos me dijeron que no hay manera porque no tienen dinero.

Averigüe sobre

la posibilidad de tener una beca y un trabajo. ¿Que hago?

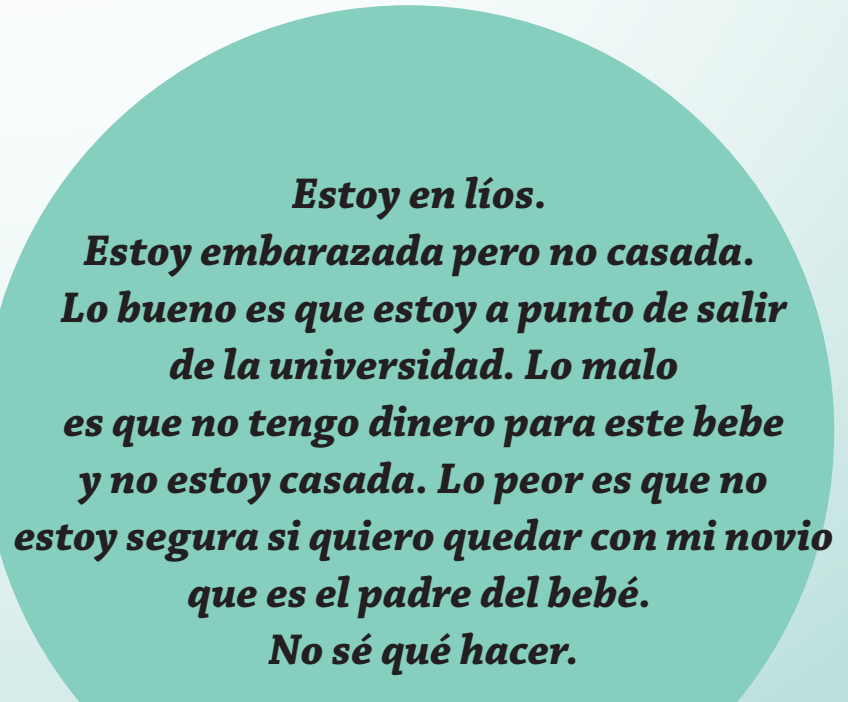




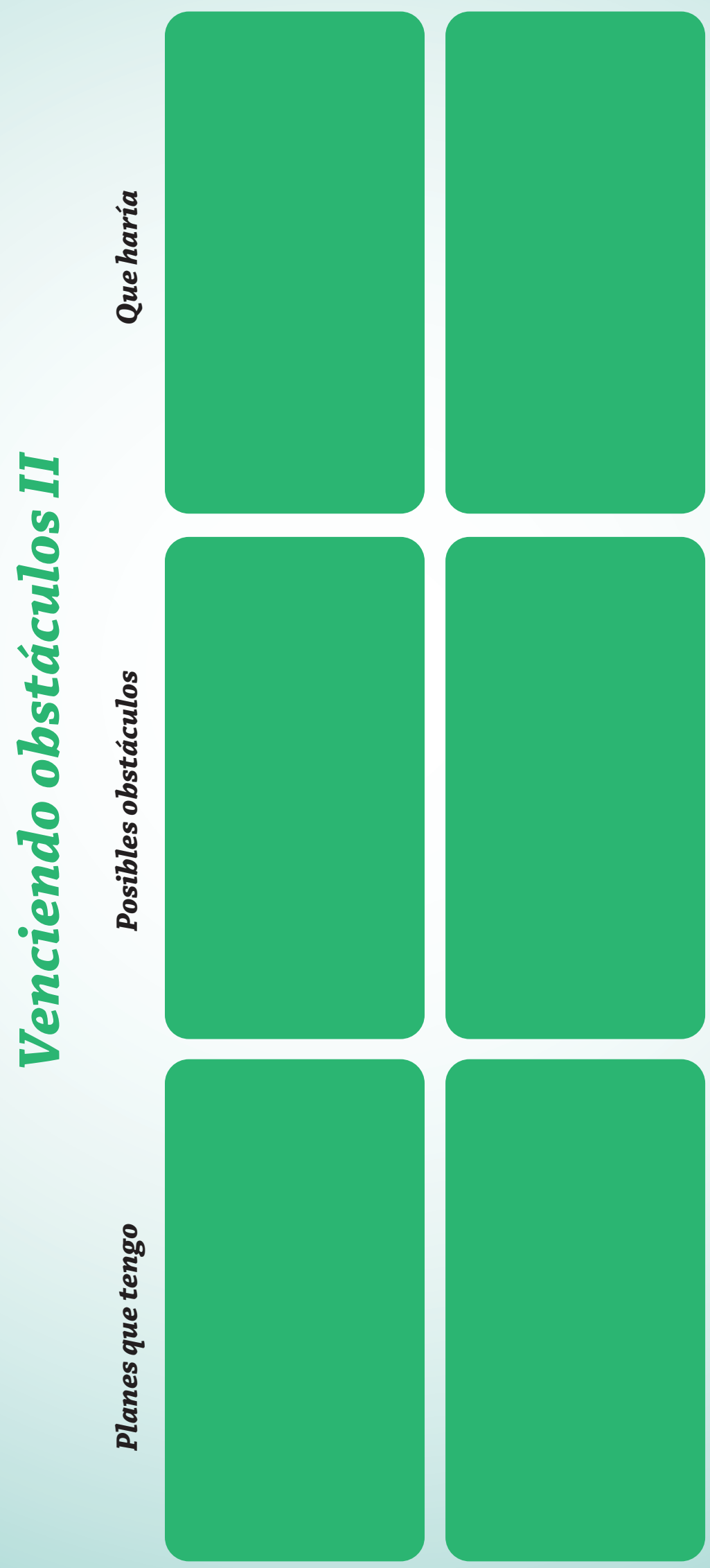




\section{La violencia se combate con valor, con inteligencia y con nuestras amigas}

\section{2 horas}
Al finalizar
la sesión las
participantes
habran...
- Nombrado diferentes formas de violencia.
- Enumerado las personas e instituciones que son responsables de combatir la violencia a las cuales pueden acudir.
- Conocido estrategias y medidas para prevenir y afrontar situaciones de violencia.
- Explicado lo que van a hacer en sus propias vidas como resultado de su participación en el curso.

\section{Conceptos Clave}

\section{Violencia:}

Son aquellas acciones que van en contra de la dignidad de una persona, limita su libertad y posibilidades de crecimiento y desarrollo.

\section{Violencia Intrafamiliar:}

Es la que comete un miembro de la familia en contra de otro, especialmente cuando viven en una misma casa

\section{Tipos de violencia:}

La violencia se puede practicar de diferentes formas como física, psicológica, económica y sexual.

MATERIAL DE APOYO:

Folletos, volantes y trifoliares con información sobre violencia doméstica, intrafamiliar, contra la mujer etc.
Sopa de imágenes Papelógrafo con preguntas Copias de los recursos de apoyo para las participantes

\section{PARA LA PRÓXIMA SESIÓN (5.5) ES NECESARIO PREPARAR INVITACIONES. REVISAR DESDE AHORA Y PLATICARLO CON LA MENTORA MONITORA}

\section{Bienvenida:}

Dé la bienvenida a las participantes, confirmando quiénes están presentes o ausentes. Comparta con ellas que el día de hoy van a trabajar sobre el tema de la violencia, especialmente en contra de la mujer y van a conocer los lugares a donde se puede pedir ayuda.

\section{Introducción del tema:}

Lleve usted hecha una sopa de recortes de mujeres que sufren violencia. Asegúrese de incluir ejemplos de todos los tipos de violencia. Permita que las participantes tengan tiempo para acercarse a ver su sopa de recortes y pídales que se junten en grupos de tres, para discutir sobre las siguientes preguntas. 
Luego de cada pregunta permita que compartan sus respuestas con el resto. Pregunte:

¿Qué acciones violentas están ocurriendo?

¿Qué parte del cuerpo se ve afectada por esta violencia?

¿Cómo, la vida de la mujer, se ve afectada por esta violencia?

¿Hay casos similares de violencia en esta comunidad?

¿Por qué la pobreza y el hambre podrían ser consideradas también formas de violencia?

Al terminar de pasar todos los grupos explique que las acciones violentas se dan de muchas formas y afectan a las víctimas de diferentes maneras. Pida que en el grupo discutan un ejemplo de violencia que conocen y hagan el dibujo en una hoja de papel. Rételas a buscar cosas diferentes, no los ejemplos comunes. En la parte de atrás del dibujo deben escribir las respuestas a tres preguntas que usted lleva en papelógrafo previamente escritas.

¿Quién está haciendo la acción violenta?

¿Quién es la víctima directa?

¿Hay otras víctimas afectadas por la acción violenta?

¿Cómo esta violencia limita el desarrollo y las oportunidades a la persona víctima?

¿Qué hacen otras personas que conocen del caso de violencia?

¿Qué partes de la víctima están siendo golpeadas?

\title{
3. Teorizar y definir:
}

Entregue a cada una el material de apoyo que tenga sobre violencia en el país. Acompañando la lectura puede realizar algunas de las siguientes preguntas:

\author{
¿Qué ven en la portada? \\ ¿Qué sentimientos expresa el dibujo? \\ ¿Qué relación hay entre salud y violencia? \\ ¿Qué conocen de la organización que hizo este material? \\ ¿Cómo afecta la violencia la salud de una mujer, una joven y una niña? \\ ¿En qué se parecen las experiencias de las mujeres de la comunidad con lo que se define \\ como violencia?
}




\section{Comparta las siguientes estadísticas de violencia con las participantes:}

Comparta las siguientes estadísticas haciendo un ejercicio de representación. Ponga en un papelógrafo los datos y luego juegue con ellas. Para realizar el ejercicio pida 10 voluntarias que pasen al frente. Luego de leer cada estadística las voluntarias representarán a las mujeres golpeadas, colocando una mancha en el rostro o en otra parte del cuerpo que simbolice haber sufrido violencia según la estadística de cada país.

\section{ESTADISTICAS EJERCICIO}

1. Alrededor del $40 \%$ de las mujeres en México han sufrido violencia en su casa

2. En Chile el 50\% han sufrido violencia de su pareja.

3. En Nicaragua $50 \%$ de mujeres han recibido golpes por parte de su esposo.

4. El $94 \%$ de las mujeres que sufren violencia física de sus parejas son también humilladas.

5. Casi el $40 \%$ de las que han sido golpeadas por su pareja también son obligadas a tener relaciones sexuales con él.
Para la primera línea pida que den un paso para delante a 4 de las 10 voluntarias y hágales una marca de violencia.

Para la segunda y tercera líneas pida que una más de paso al frente y la marca con señal de violencia.

Para la cuarta línea pida a cuatro compañeras que no están al frente que pasen a insultar a otras cuatro de las cinco que han sufrido violencia y le coloquen un corazón roto en 4 de las 5 que están marcadas.

Para la quinta línea pida que de las cinco voluntarias golpeadas dos se acuesten en el suelo, representando violencia sexual.

Abra el espacio para que comenten sus impresiones acerca de la violencia y puedan empezar a dar algunas ideas sobre lo que han aprendido hasta ahora de la violencia. Apunte sus ideas en un papelógrafo.

Forme tres grupos y entregue a cada grupo una de las siguientes leyes: Constitución Política de la República, Ley protección integral de la niñez, Ley para perevenir, sancionar y erradicar la violencia intrafamiliar, Ley de femidio y otras formas de violencia contra la mujer y ley contra la violencia sexual, explotación y trata de personas. Pida que identifiquen en el grupo qué instituciones y personas son responsables de ayudar a combatir la violencia y las escriban en un papelógrafo. Luego las deben presentar a la plenaria.

\section{Aplicación para la vida:}

Pida que se junten en grupos de cuatro y entregue folletos, volantes, hojas que tienen información sobre lo que puede hacer una persona al sufrir violencia. Pida que en su grupo lean la información que les ha entregado y que escribirán un plan de acción en el que identifiquen:

- Tipos de violencia que pueden sufrir las niñas y jóvenes de su comunidad.

- Lugar donde se presenta y personas que la realizan.

- Instituciones a las que pueden pedirles ayuda para que obliguen a cambiar las acciones violentas.

- Acciones que ellas pueden realizar para prevenir. 
Al finalizar

la sesión las

participantes

habran...
-Enumerado los servicios que existen en la comunidad.

-Conocido la función de cada uno y las personas que allí laboran.

-Visitado para conocer y se dan a conocer en los servicios de su comunidad y municipio.

\section{Conceptos Clave}

Servicio Público: servicio que ofrece el Estado a todos los ciudadanos con la finalidad de contribuir a la garantía de derechos y desarrollo de la población.

Funcionario/a: Persona que trabaja en alguna dependencia del estado.

\section{2 horas}

$$
\text { ( }
$$

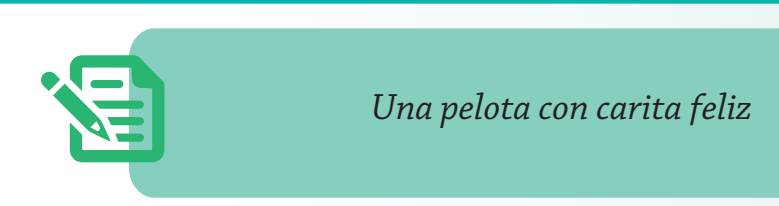

\section{Bienvenida:}

Dé la bienvenida a las participantes, confirmando quiénes están presentes o ausentes. Comparta con ellas que el día de hoy vamos a conocer acerca de las personas que atienden desde el servicio público a la población y son responsables de cuidar algunos de los derechos de los y las ciudadanas.

\section{Introducción al tema:}

Diga a las participantes que recibirán la visitas de personas de la comunidad que sirven en posiciones de liderazgo y su trabajo es como el de la sábana en conjunto apoyan y mejoran la comunidad.

\section{ANTES DE LA LLEGADA DE INVITADOS}

Pida a las participantes que formen una rueda grande y entre todas sostengan la sábana/red. Dígales que la pelota las representa a ellas y que ellas son responsables de que la pelota no se golpee contra el suelo usando la sábana y levantándola llevando la pelota de un punto a otro que será su meta. Tire la pelota al centro de la sábana y anímelas a que jueguen y lleven la pelota a su meta. Si son muchas puede hacer dos grupos y que hagan competencia entre ellas en ver quién lleva la pelota antes a la meta sin botarla. Luego de jugar pregunte a las participantes: 
¿Qué pasó con la pelota?

¿Para qué sirvió la sábana?

¿Qué hubiera pasado con la pelota sin la sábana?

¿Qué pasaría si alguna de las partes de la sábana tuviera hoyos o si alguna del equipo suelta la sábana de su lado?

¿Cómo pueden comparar la sábana con las personas que las ayudan a alcanzar sus metas?

¿En qué momentos sienten que pueden necesitar la ayuda de una organización de la comunidad?

¿Qué instituciones conocen en la comunidad que les puede ayudar?

\section{Técnica de facilitación}

Dos o tres semanas antes de esta sesión la mentora de

grupo debe contactar e invitar a líderes comunitarios a

asistir a la sesión para un encuentro con las

participantes. Solicite una carta formal para hacer la

invitación y entregarla con tiempo.

Algunas personas que podría invitar:

Alcalde/sa auxliar

Comadrona

Director/a de la Escuela

Doctor/a, enfermera/o, técnico rural del Centro de

Salud Monitoras comunitarias

Miembros de:

COCODES

Comité de Jóvenes

Comité de refacción escolar

Comisión de salud

Comité de cultura y deportes

Comité de agua

Comité de padres de familia

Oficina municipal de la mujer

\section{AL MOMENTO DE LLEGADA DE INVITADOS/AS}

Pida que las que acompañen estén listas para recibir a los invitados/as cuando lleguen y llevarlos/as a la silla para cada uno y que coloque el gafete con su nombre. El resto de las participantes deberán estar sentadas en media luna frente a las sillas de invitados. Diga:

\section{En esta comunidad hay varias personas que trabajan para servir a la población y hoy tenemos el gusto de que nos están acompañando. Voy a presentarle a cada persona que nos acompaña dicién- doles su nombre y en qué trabaja.}

Invite a las participantes a formar sus grupos y a las voluntarias acompañantes que lleven a su invitado/a al grupo que corresponde. Estando allí la secretaria de cada grupo debe preguntar al invitado/a:

¿Qué le gusta de servir a la comunidad? ¿Qué fortalezas pone al servicio de los demás? ¿Cómo le hace feliz servir a la comunidad?

Luego ir presentando las preguntas que hicieron las participantes para cada uno. Permita 30 minutos para trabajar en los grupos.

Regrese a todas a su lugar inicial y de la palabra a algunas participantes que quieran compartir algo lindo que aprendieron. Luego agradezca a los invitados por su asistencia y su tiempo. 


\subsection{Las necesidades de mi comunidad}

\section{2 horas}

\section{Al finalizar \\ la sesión las \\ participantes \\ habran... \\ - Conocido los objetivos de desarrollo sostenible y los derechos humanos. \\ - Identificado las necesidades de su comunidad en relación con los objetivos de desarrollo sostenible y los derechos humanos \\ - Priorizado una necesidad sobre la que les gustaría trabajar. \\ - Contactado a una persona de su comunidad que trabaja en la necesidad seleccionada.}

\section{Conceptos Clave}

\section{Objetivos de desarrollo sostenible -ODS-:}

Metas que se han acordado en organismos internacionales que debieran alcanzar todos los países en los próximos 15 años, para poner fin a la pobreza, luchar contra la desigualdad y la injusticia, y hacer frente al cambio climático.

\section{MATERIAL DE APOYO:}

Folletos con información sobre los Objetivos de

Desarrollo Sostenible -ODS-
Papelógrafos con personajes a representar de la comunidad, marcadores,

\section{Bienvenida}

Dé la bienvenida a las participantes, confirmando quiénes están presentes o ausentes. Comparta con ellas que el día de hoy van a empezar a reflexionar en torno a su comunidad y las necesidades que tiene, considerando lo que la humanidad se ha propuesto como condiciones mínimas de vida a las que debiéramos alcanzar todas las personas.

\section{Introducción al tema:}

Juega adivina adivinico. Divida al grupo en 9 subgrupos y entregue a cada uno una hoja con el dibujo de una personas a repsentar de la comunidad (ver cuadro en la página 218). Pídales que discutan cómo vive este grupo de personas en la comunidad. A partir de allí deben escribir un guión en el que se presentará al resto de participantes para que adivinen el sexo y la edad de quien están representando. 


\section{PERSONAS A REPRESENTAR}

\section{Bebé \\ Grupos: \\ Nena 5 años \\ Nene 5 años \\ Joven mujer 12 años \\ Joven hombre 12 años}

Adulta 22 años

Adulto 30 años

Anciano 65 años

Anciana de 70 años

Al pasar todos los grupos, pregunte:

¿Qué necesidades son comunes a todos y todas?

¿Qué derechos se violan en estas necesidades?

¿Qué otros problemas traen estas necesidades a la comunidad?

¿Cómo afecta la vida de ustedes estas necesidades?

\section{Teorizar y definir:}

Explique que, así como el mundo se puso una meta de los derechos a respetar, más recientemente se puso una meta de las condiciones de vida que debieran tener todos en el año 2030 y las van a leer juntas. Lea la definición del concepto clave de esta sesión. Entregue a cada participante un folletito de con información de los Objetivos de Desarrollo Sostenible -ODS-

Pregunte:

¿Cuáles creen que son prioritarias para esta comunidad?

¿Qué esfuerzos ha hecho el gobierno en los últimos años por alcanzar esta meta?

¿Qué esfuerzos han hecho otras personas por alcanzar esta meta?

¿A qué meta les gustaría aportar personalmente?

¿Qué pediremos al COCODE? 


\title{
4. Aplicación para la vida:
}

Cada una va a circular a qué ODS -Ojetivo de Desarrollo Sostenible-quiere aportar y qué necesidades de la comunidad se relacionan con ese objetivo que le interesa.

Deberán acercarse a alguien de la comunidad o fuera de ella que trabaje en ese objetivo o en resolver las necesidades para cumplirlo y leerle cuál es el ODS que se ha puesto y preguntarle:

\author{
¿Cómo lo ve? \\ ¿Qué hace ella/el por alcanzarlo? \\ ¿Por qué es importante su trabajo? \\ ¿Qué características requiere alguien que trabaja en eso? \\ ¿Qué satisfacciones le trae?
}

En la siguiente sesión deben llevar sus trabajos y entregarlos a la mentora de grupo.

Estos se estarán revisando nuevamente en el siguiente trimestre. 


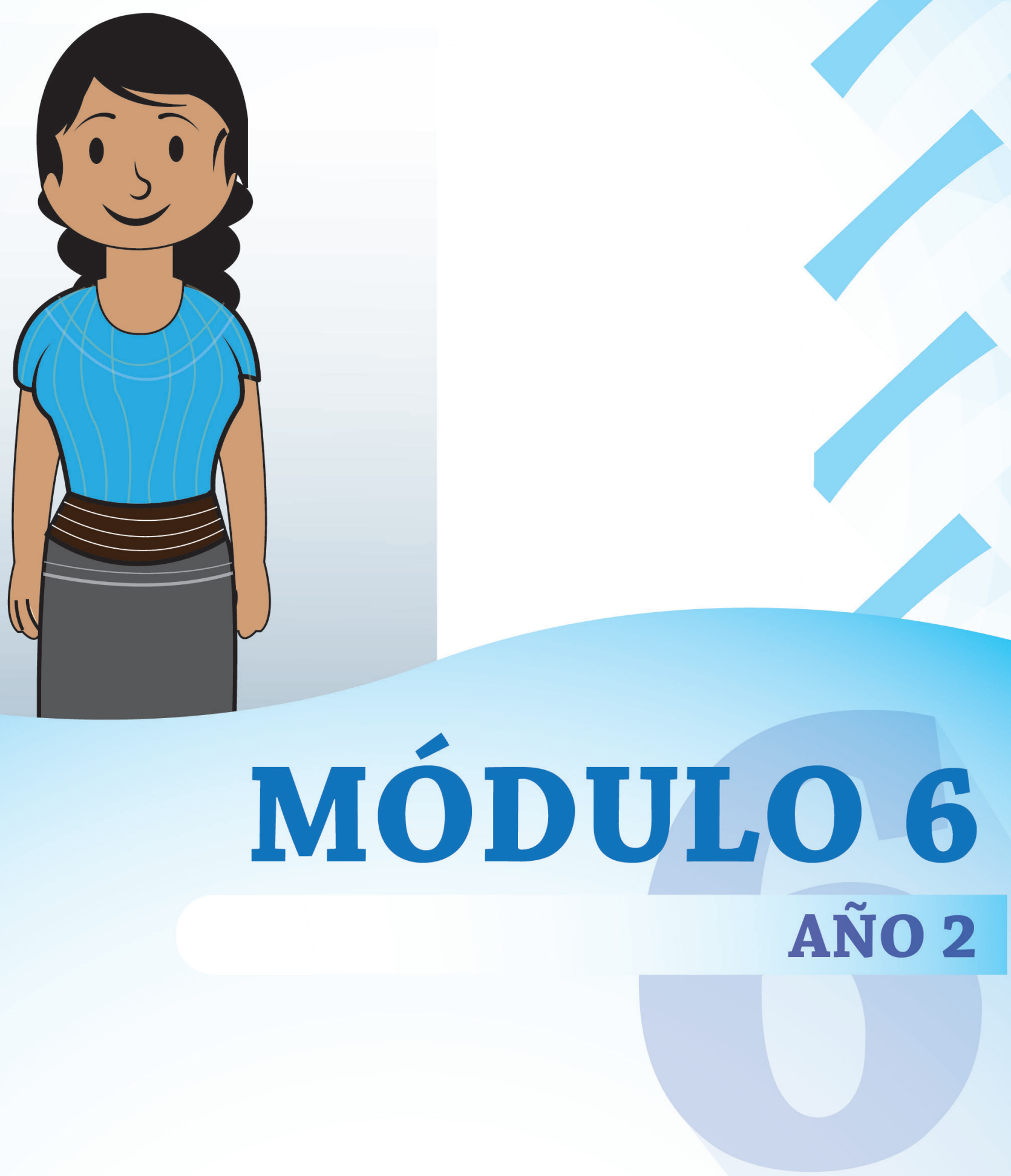

Guía Curricular Integrada 2015 - Population Council 


\section{Créditos}

- Autoras:

María Cecilia Garcés de Marcilla/Especialista en Educación

$\checkmark$ Paola Broll / Oficial del Programa

- Revisión: Alejandra Munguía/ Coordinador de Campo

- Diagramación:Isaí de la Cruz

- Equipo Population Council 2015:

$\checkmark$ Directora de Programas: Alejandra Colom

$\checkmark$ Supervisor de Monitoreo y Evaluación y oficial de Programa: Ángel del Valle

$\checkmark$ Administradora: Ana Lucía Rodríguez

- Mentoras: Elizabeth Vásquez, Claudia Macz, Sonia Chó, Patricia Alva, Maribel Gutiérrez, Fabiola Colop y Rosa Güit 


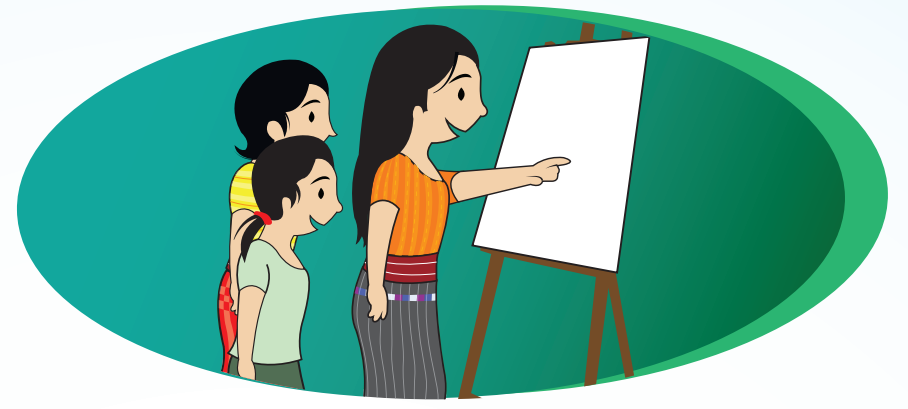

\section{AÑO 2}

\section{Módulo VI}

El período final del programa se centra en las herramientas que permiten a las niñas y jóvenes consolidar su plan de vida. Por medio de la profundización de Salud Sexual y Reproductiva y el fortalecimiento personal pueden ejercer acciones concretas para cuidar su vida; por medio de la proyección comunitaria se les invita a presentar a la comunidad los logros que han tenido y las potencialidades que han desarrollado para aportar a la vida de todos y todas. En este sentido empiezan a ser vistas como jóvenes trabajadoras con planes y capacidad de liderar a otras personas en procesos de desarrollo humano y también procesos productivos.

\section{Grupo de 8 a 12}

6.1 Proyección comunitaria: Derechos de las niñas de mi comunidad

6.2 Fortalecimiento personal: Mujeres adultas que admiro por su trabajo

6.3 Fortalecimiento personal: Las necesidades de mi comunidad

6.4 Proyección comunitaria: Imagino lo que puedo alcanzar en mi vida

6.5 Proyección comunitaria: Mi regalo para la comunidad.

\section{Grupo de 13 a 17}

6.1 Salud sexual: En mis relaciones de noviazgo yo decido

6.2 Salud sexual: Informándome sobre ITS y el VIH/SIDA

6.3 Salud sexual: Planificación familiar

6.4 Proyección comunitaria: Soy un aporte para el desarrollo

6.5 Proyección comunitaria: Mi aporte a la comunidad. 
Grupo de 8 - 12 años niños/Mujeres adultas que admiro por su trabajo

Al finalizar

la sesión las participantes habrán...
- Identificado el grado de acceso que tienen a ellos.

- Nombrado a quién pueden pedir ayuda en la comunidad para cuidar los derechos de las niñas y niños

- Conocido a personas en su comunidad que trabajan en los derechos de la niña y los niños

\section{Conceptos Clave}

Derechos Humanos: garantías que da el estado de condiciones de vida que deben ser respetadas para todas las personas.

Derechos de los niños y niñas: garantías especiales para niños y niñas por ser un grupo en desarrollo y crecimiento que requiere de más protección y cuidado por parte de los adultos.
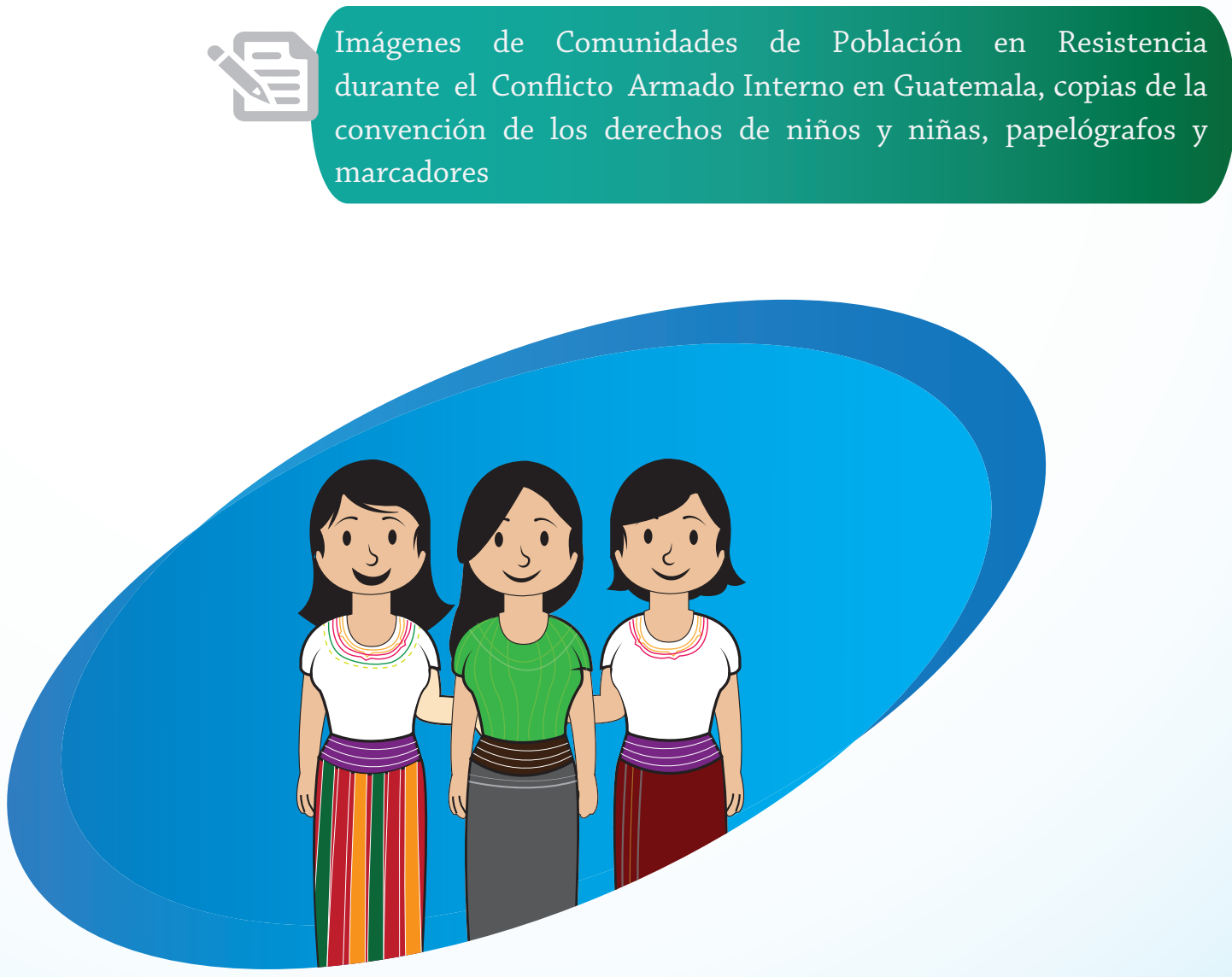


\section{Día 1-6.1}

\section{Bienvenida:}

De la bienvenida a las niñas, confirmando quiénes estan presentes o ausentes. Felicite a todas por estar terminando la última fase de guía del programa y permita que le cuenten qué cosas han aprendido y qué quieren empezar a actuar ya.

Comente que este trimestre van a dedicarse a ver su comunidad y pensar cómo todo lo que han aprendido puede servir para mejorar la vida de la comunidad. Pida que caminen por el salón pensando en una persona de su comunidad que admiran. Se van a chocar y encontrar con sus amigas, al hacerlo deben verse mutualmente e identificar quién es.

\section{Introducción al tema:}

Muestre a las participantes imágenes de comunidades desplazadas por el conflicto armado interno y cuénteles que son imágenes reales de hace unos 30 años en Guatemala. Permita que observen y comenten acerca de las imágenes. Mientras lo hacen diga a las participantes:

Estas son fotos de hace unos treinta años en Guatemala cuando el país vivía un guerra en la que se dio mucha violencia en contra de personas por su religión, su cultura, el lugar donde vivian, por su forma de pensar, y la forma de expresarse. Para sobrevivir muchas comunidades tuvieron que irse de sus aldeas para vivir en la montaña sin recursos ni nada que llevar con ellas. Alli estuvieron escondidas para que no las encontraran.

¿Conocen historias de personas, familias o comunidades que tuvieron que huir del lugar donde vivían? ¿Cómo era la vida para ellos?

Anote las respuestar en un papelógrafo, explique que van a formar grupos de cuatro o cinco particpantes y diga:

Imaginen que ustedes son lideresas de una comunidad que está escondida en la selva y quieren que en esa nueva comunidad todas las personas vivan una buena vida que sean felices y tengan lo que necesitan para vivir y desarrollarse. Deben escribir en su grupo una lista de 10 condiciones minimos que todas las personas de la comunidad deben tener y respetar. Tienen diez minutos para escribir su lista.

¿Conoce los derechos de los niños y niñas?

¿Cómo se cumple en la comunidad el derecho que corresponde al grupo?

¿Cuándo no se cumple?

¿A quiénes se les cumple menos ese derecho? ¿Por qué?

¿Qué hacen los adultos para hacer cumplir ese derecho?

Explique a las participantes que el tema se va terminar la próxima sesión. 


\section{Día 2-6.2}

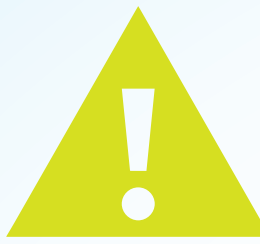

Antes de la sesión invite a líderes y lideresas comunitarias que trabajan en derechos de la niñez en su comunidad para presentarlos al grupo y permitir que dialoguen sobre la situación de los derechos. Explique que les va a pedir que se presenten indicando su nombre, lugar de trabajo y derecho de la niñez que apoya y que digan: ¿Porqué cree que ese derecho es importante?, ¿Quiénes en la comunidad ven más en riesgos sus derechos?, ¿Qué pueden hacer los niños para ayudarles a defender los derechos de la niñez?

\section{ANTES DE LA LLEGADA DE INVITADOS/AS}

Diga a las participantes que recibirán la visitas de personas de la comunidad que sirven en posiciones de liderazgo y su trabajo es como el de la sábana en conjunto apoyan y mejoran la comunidad.

\section{AL MOMENTO DE LLEGADA DE INVITADOS/AS}

Pida que las que acompañen estén listas para recibir a los y las invitada cuando lleguen y llevarlos/as a la silla para cada uno/ a y que coloque el gafete con su nombre. El resto de las participantes deberán estar sentadas en media luna frente a las sillas de invitados. Diga:

En esta comunidad hay varias personas que trabajan por servir a la población y hoy tenemos el gusto de que nos están acompañando. Voy a presentarles a cada persona que nos acompaña diciéndoles su nombre y en qué trabaja y ellos nos van a contar sobre el derecho

Técnica de facilitación

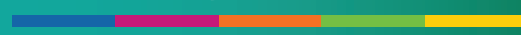

Dos o tres semanas antes de esta sesión la facilitadora debe invitar a tres lideresas comunitarios a asistir a la sesión para un encuentro con las participantes. Solicite una carta formal para hacer la invitación y entregarla con tiempo. Algunas personas que podría invitar:

Alcaldesa auxliar

Comadrona

Directora de la Escuela

Doctora, enfermera

Monitoras comunitarias

Miembras de COCODES

Oficina municipal de la mujer

Fiscal del Ministerio Público en el depto.

Jueza Organismo Judicial en el depto.

Integrante de una Organización Local de Desarrollo de las niñez que apoya, además nos van contar sobre:

¿Porqué cree que ese derecho es importante?,

¿Quiénes en la comunidad ven más en riesgos sus derechos?, ¿Qué pueden hacer los niños para ayudarles a defender los derechos de la niñez?

Ante de darles participación a cada invitado pida a cada niña que en su cuaderno escriban tres cambios en su vida que deben darse para ayudar a que se cumplan los derechos de las niñas y los niños de toda la comunidad.

Luego permita a cada participante contar sobre el trabajo que hace y que las niñas puedan hacer preguntas a lo largo de su presentación para hacer una especie de diálogo.

Luego agradezca a los invitados por su asistencia y su tiempo. 
Al finalizar

la sesión las

participantes

habrán
- Conocido en los objetivos de desarrollo sostenible -ODS- y los derechos humanos. - Identificado las necesidades de su comunidad en relación con los objetivos de desarrollo sostenible y los derechos humanos

- Priorizado una necesidad sobre la que les gustaría trabajar.

- Contactado a una persona de su comunidad que trabaja en la necesidad seleccionada.

\section{Conceptos Clave}

Objetivos de desarrollo sostenible -ODS-:

Metas que se han acordado en organismos internacionales que debieran alcanzar todos los países en los próximos 15 años, para poner fin a la pobreza, luchar contra la desigualdad y la injusticia, y hacer frente al cambio climático.

\section{Bienvenida:}

Dé la bienvenida a las participantes, confirmando quiénes están presentes o ausentes. Comparta con ellas que el día de hoy van a empezar a reflexionar en torno a su comunidad y las necesidades que tiene, conociendo las metas que el mundo se ha propuesto alcanzar para el 2030.

\section{Introducción al tema:}

Juegue con ellas "adivina adivino quien tiene esta necesidad que no es el mico". Pegue un papelógrafo con la lista de las siguientes poblaciones de la comunidad y explique que usted irá diciendo algunas características de lo que cada una de estas poblaciones necesita y ellas deberán adivinar cuál papelógrafo es al que usted hace referencia. Pegue el papelógrafo de cada grupo a la vista de todas.

Bebés:

\section{Necesitan leche, que su familias los cuide todo el tiempo, pañales, chamarras}

Niñas y niños:

Necesitan buena alimentación, empezar a ir a la Escuela a aprender a leer y escribir, tener el cariño y amor de su familia, jugar y divertirse.

Jóvenes:

Necesitan alimentación, conocerse bien a sí mismas y a sus parejas, tomar decisiones sobre la planificación de su familia y cómo prevenir embarazos y enfermedades de transmisión sexual. 
Mujeres adultas embarazadas:

\section{Necesitan buena alimentación, atención a sus bebés antes-durante y después del parto, apoyo para trabajar y alimentar a sus hijos e hijas.}

Al terminar pregunte:

¿Qué necesidades son comunes a todos y todas?

¿Qué derechos se violan cuando no se cumplen estas necesidades?

¿Cómo afecta la vida de ustedes estas necesidades cuando estas no están satisfechas?

¿Qué problemas enfrenta la comunidad para que se satisfagan todas las necesidades?

\section{Teorizar y definir}

Explique que, así como el mundo se puso una meta de los derechos a respetar, más recientemente se puso metas de las condiciones de vida que debieran tener todos en el año 2030 y las van a leer juntas. Lea la definición del concepto clave de esta sesión.

Entregue a cada participante un folletito de información sobre los objetivos de desarrollo sostenible -ODS-. Pregunte:

¿Cuáles creen que son prioritarias para esta comunidad?

¿Qué esfuerzos ha hecho el gobierno en los últimos años por alcanzar esta meta?

¿Qué esfuerzos han hecho otras personas por alcanzar esta meta?

¿A qué meta les gustaría aportar personalmente?

\section{Aplicación para la vida:}

Cada una dibujará a qué Objetivo de Desarrollo Sostenible -ODS-le interesa más aportar en la hoja de trabajo "Metas Compartidas". 


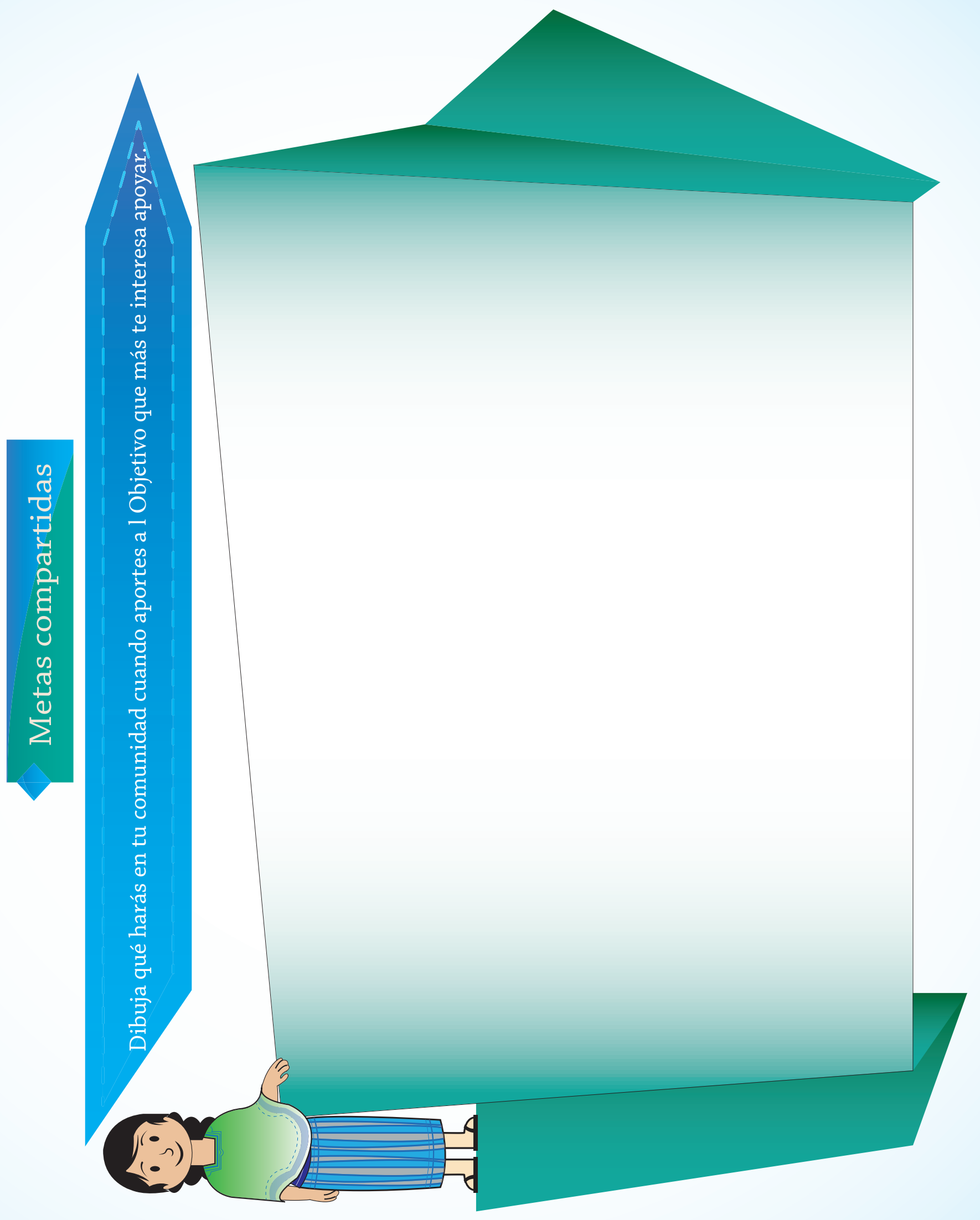


Al finalizar

la sesión las

participantes

habrán...
Comprendido qué es el desarrollo humano y cómo se alcanza.

Escrito su plan de vida considerando sus metas personales y lo que pueden aportar a su comunidad.

Propuesto acciones que pudieran realizarse dentro de su comunidad para mejorar el desarrollo humano.

\section{Conceptos Clave}

Desarrollo humano: considera la calidad de vida de las personas, que siempre debiera ir en constante mejora. Identifica la calidad de vida según el grado educativo, los ingresos y los años que viven las personas en una comunidad, municipio, departamento, país.

Plan de vida: Trazarse el camino para alcanzar lo que uno quiere desarrollar en su vida a corto, mediano y largo plazo.

Hoja de trabajo

\section{Bienvenida:}

Dé la bienvenida a las participantes, confirmando quiénes están presentes o ausentes. Comparta con ellas que el día de hoy van a identificar lo valiosa que puede ser cada una para el desarrollo humano de su comunidad. Empieza por el reconocimiento en todas las cualidades y fortalezas que tienen que puedan aportar al desar-rollo de la comunidad con el juego "Las botella de las cosas Buenas".

Siente a las participantes en un círculo y coloque en el centro una botella. Pida a alguna que empiece por girarla y que cuando la botella se detenga le va a decir a la compañera a la que señale la botella una fortaleza y cómo puede aportar al desarrollo de la comunidad. Luego ella hará el ejercicio, hasta que pasen todas y a todas se les diga una cualidad y cómo puede aportar a la comunidad.

\section{Introducción al tema:}

Presente a las niñas un papelógrafo con algunas frases dichas por las mujeres lideresas que llegaron a la activi-dad en la sesión 6.2 y pida que las lean juntas. Mientras usted dialoga con ellas sobre el significado de la frase, pida que cada niña identifique una frase que la hace sentir que ella es maravillosa, tiene mucho que dar y puede decidir sobre su propia vida. Para motivar al diálogo y reflexión puede preguntar: 


\section{¿Qué aprenden de las frases? \\ ¿Cómo el trabajo de una persona puede cambiar algo en su comunidad? ¿Qué cosas creen que podrían hacer ustedes?}

\section{Teorizar y definir}

Lea la definición de Desarrollo Humano que está en los conceptos clave y recuerden cuáles son los objetivos de desarrollo sostenible que más les habían interesado. Piensen que ellas son ahora responsables de aportar a alcanzar las metas y mejorar el desarrollo en su comunidad pero que van a empezar por su familia, escuela y amigas. Explique:

Desde que una persona nace, tiene la posibilidad y el derecho de tomar decisiones sobre lo quiere ser y hacer para su vida. Muchas veces pasamos la vida, crecemos y nos morimos sin pensar en esto ¿Qué quiero ser y hacer en mi vida? ¿Para qué soy buena? ¿Cómo puedo contribuir? ¿Cómo lo puedo lograr?

\section{Aplicación para la vida}

Eso es precisamente lo que van a pensar el día de hoy y en la próxima sesión. Empecemos por el inicio. Cada una de ustedes tiene fortalezas para apoyar su vida y que mejore la vida de la comunidad, pensando en sus fortalezas y en las metas y necesidades de su comunidad cada una tiene que contestar en silencio a las siguientes preguntes en la hoja de trabajo "Ya estoy aportando".

¿Qué necesidad/meta creo que es importante alcanzar?

¿Qué fortalezas tengo para aportar a mi familia?

¿Cómo puedo ayudar a alcanzar esa meta en mi familia, escuela y con amigas?

De tiempo para que puedan trabajar de forma individual en la hoja de trabajo. Dígales que pueden dibujar o escribir pero lo más importante en este momento es que piensen sobre su vida y el valor que ellas tienen. 


\section{YA ESTOY APORTANDO}

Guía Curricular Integrada 2015 · Population Council 


\subsection{Mi regalo para la comunidad}

(b) 2 horas

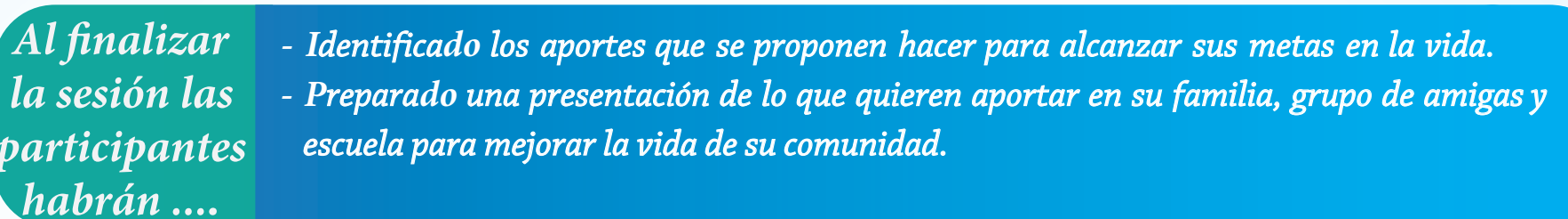

Hojas en blanco, papelógrados Crayones marcadores y materiales para decorar su trabajos

\section{Bienvenida:}

Dé la bienvenida a las participantes, confirmando quiénes están presentes o ausentes. Comparta con ellas que el día de hoy van a identificar lo valiosa que puede ser cada una para el desarrollo humano de su comunidad.

\section{Introducción al tema:}

Hemos aprendido temas importantes para la vida de mujeres y niñas en esta comunidad, cosas sobre derechos humanos, género, salud de la mujer, finanzas etc. Todos los temas son parte de la vida diaria de nosotras y de otras personas. Pregunte ¿Qué temas les llamaron más la atención?, las respuestas anótelas en un papelógrafo

En la sesión pasada ustedes reflexionaron sobre qué necesidades de la comunidad quieren aportar y qué metas tienen para su vida. Vamos a escucharlas a todas ahora para conocer la riqueza que tiene este grupo que regalar a sus familias, escuelas y amigas.

\section{Teorizar y definir}

\section{Diga a las participantes:}

En esta hoja que les estoy dando van a escribir de forma individual qué es lo que quieren ser y hacer en su vida. Escriban suficiente porque esto se va a compartir con sus familias y líderes de la comunidad para que conozcan sus sueños y metas y las puedan apoyar en alcanzarlas. De un tiempo de 20 minutos para que trabajen en esta parte. 


\section{Reflexionando en la Aplicación para la Vida}

Luego de que hayan terminado pida que todas coloquen su nombre en su hoja en un lugar visible y dé las instrucciones de la segunda actividad.

Para alcanzar los sueños de todas, será más fácil si toda la comunidad está mejor y ustedes desde ya están aportando a su familia, amigas y escuela para que la vida de las niñas sea mejor. Esta hoja que reciben la van a dividir en tres columnas. En la primera escribirán Familia, en la segunda Amigas y en la tercera Escuela. En cada columna van a escribir una fortaleza que ustedes tienen que van a usar para apoyar las necesidades de su familia, escuela y amigas. Debajo de su fortaleza dibujen qué cambio harán en cada lugar con su aporte.

De también unos 30 minutos para que trabajen. Asegúrese de que pongan el nombre a sus trabajos y los entreguen.

Diga a las participantes que harán una sesión de clausura en la que presentarán el trabajo que han hecho a sus familias, líderes comunitarios y las personas que les han apoyado durante el programa. Entregue las invitaciones para que ellas den a sus familias (la pueden elaborar juntas en la próxima sesión) y pida que le lleven también <las manualidades que quieren dar a conocer a todos.

Antes de la fecha: Invite y confirme con los líderes y lideresas que puedan llegar a la actividad. Tal vez tenga que cambiar de día y hora para que más personas puedan llegar.

Prepare desde antes el salón con los trabajos y las manualidades de las niñas, pídales que lleguen temprano para que la ayuden a preparar el salón también.

\section{Clausura}

Durante la actividad dé la bienvenida a los/as asistentes, cuente un poco sobre el programa, pida a una niña que comparta qué aprendió durante el programa, entregue diplomas a las niñas e invite a las familias a ver los trabajos hechos por el grupo. 
Al finalizar

la sesión las

participantes

habrán...

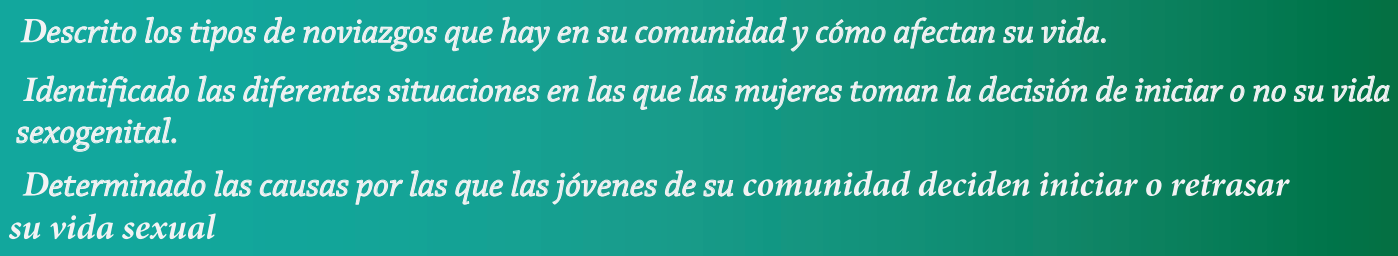

\section{Conceptos Clave}

Autonomía:

Es la capacidad de tomar mis propias decisiones de forma informada y la oportunidad para actuar de acuerdo a lo que he decidido. En una relación la autonomía permite que cada parte se desarrolle de acuerdo a sus deseos, metas, necesidades. Para ejercer autonomía es necesaria tener una autoestima bien cimentada, conocer las metas y deseos propios y contar con información suficiente.

\section{Bienvenida:}

Dé la bienvenida a las participantes y tome asistencia de quiénes están presentes y ausentes. Diga a las participantges que este día van a conversar sobre el noviazgo.

\section{Introducción del tema:}

Juegue "la confianza en mi pareja": En un espacio libre grande haga una pista de obstáculos a manera de hacer dos caminos con cosas que se interpongan. Puede usar basureros, botes de leche, escritorios, sillas, pelotas. Antes de llegar a donde está la pista de obstáculos pida la participación de tres parejas e indique que el resto de las participantes van a ser observadores. Indique a cada pareja que van a pasar juntas por una pista de obstáculos. En una pareja habrá una de ellas con los ojos vendados y la otra no; en la otra pareja ambas tendrán los ojos vendados; en la última ninguna tendrá los ojos vendados. Pasará una por una, empezando por la pareja que tiene los ojos vendados, luego la pareaja donde una sí una tiene los ojos vendados y otra no y al final la pareja que no los tiene vendados. Luego de cada pareja pregunta cómo se sintieron al pasar los obstáculos. Pregunte al grupo:

¿En qué se parece la vida a una pista de obstáculos?

¿Qué relaciones de pareja ayudan a pasar la vida mejor y más fácil? ¿Qué

relaciones de pareja lo hacen más difícil?

¿Cómo son las relaciones de pareja en su comunidad?

¿Qué situaciones les gustan de los noviazgos en la comunidad?

¿Qué no les gusta de los noviazgos?

¿Qué cosas sienten que les dañan?

¿Por qué razones decidimos en esta comunidad tener novio? 


\section{Teorizar y definir:}

Realice la dinámica: Decidiendo cuándo y con quién iniciar la vida sexual.

Solicitar a cinco voluntarias, quienes van a presentar un sociodrama a sus compañeras. El resto del grupo participa en un grupo de discusión sobre cómo son las relaciones y cuándo tienen que decidir sobre su vida sexual.

Luego las voluntarias presentan el sociodrama al grupo y entre todas discuten por qué razones deciden las jóvenes de la comunidad iniciar su vida sexual y por qué razones deciden retrasarla. Escríbalas en dos papelógrafos titulados cada uno: Razones para decir sí /Razones para decir no.

\section{Historia para el Sociodrama:}

María tiene 18 años estudia su segundo año de carrera y le gusta mucho lo que está aprendiendo, quiere dedicarse a trabajar de maestra al graduarse. Desde hace dos años es novia de Elías, que está estudiando mecánica y le faltan dos años para graduarse. Sienten que se aman mucho y Elías le insiste a María que le cumpla con

la prueba de amor. María siente que sí lo quiere pero no está segura de empezar a tener relaciones sexogenitales con él. Algo le da miedo.

\section{Una tarde Elías acompañó a María a su casa después de la sesión en Abriendo Oportunidades ella le compartió que aprendieron sobre los métodos anticonceptivos. Como habían caminado mucho, decidieron sentarse a descansar a la orilla del camino, ellos estaban sol}

\section{Elías empezó a acercarse mucho a María ella se sintió nerviosa pero muy emocionada y le gustó lo que} estaba pasando, no lograba quitarse de la cabeza un sentimiento de duda.

\section{Diez Razones para Retrasar el Sexo}

1. Solamente no tener sexo es $\mathbf{1 0 0 \%}$ efectivo para evitar un embarazo

2. No tener sexo impide contraer una ITS y el VIH

3. Prevención de violencia: una relación sexogenital puede ser forzada a tener sexo.

4. Es importante dejar que crezca la amistad entre ambos antes de tener sexo

5. Podemos ser muy jóvenes y no estar preparados para las consecuencias de tener sexo

6. Esperar a la personas ideal, que de verdad nos ame y el sexo sea una forma para cuidarnos y querernos, en vez de aprovecharse de nosotros por eso

7. Evitar más presiones de la familia y la comunidad sobre nosotros, que al enterarse de que se está teniendo sexo podrían obligar a casarse.

8. Proteger nuestra autoestima, saber que me aman por quienes somos y no por la posibilidad de tener sexo con uno.

9. Establecer una vida familiar con la menor cantidad de presiones posibles. El sexo hace que las cosas a veces se compliquen, es mejor empezar una familia con las menos complicaciones posibles.

10. Estar seguro que es una decisión propia y libre, saber que no hay ninguna presión que nos está llevando a tomar la decisión. 


\section{Diferencia entre sexo deseado, sexo voluntario y sexo forzado:}

Hablar con el grupo sobre la diferencia entre el deseo, la voluntad y la fuerza, usando ejemplos que son comprensibles por ellas y pidiendo que ellas también den sus propios ejemplos. Explicar que también se pueden aplicar estas ideas a la forma en que se inicia la vida sexual. Preguntarles qué piensan ellas que es el sexo deseado, sexo voluntario y sexo forzado.

Reforzar qué es cada uno y la diferencia.

\section{Aplicación a la vida:}

Revisar la lista que dieron de porqué dicen SÍ al inicio de las relaciones sexogenitales e identificar para cada una si es un caso de sexo deseado, voluntario y forzado. Comentar sobre los retos de tomar decisiones libremente en la comunidad.

Completar la hoja de trabajo "Mi cuerpo mis derechos". 


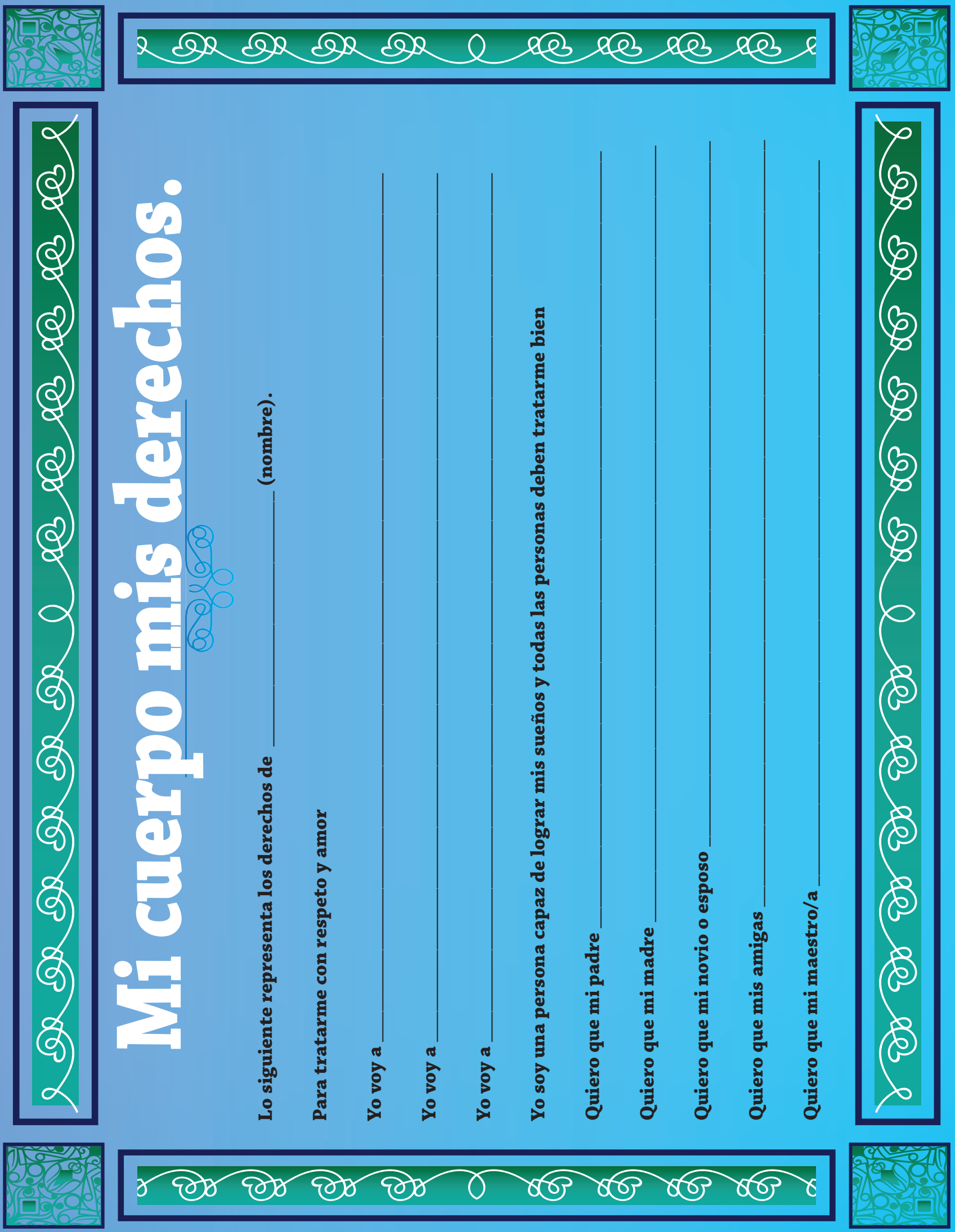


Al finalizar la sesión las participantes habrán...
Experimentado como las ITS y VIH se transmiten en cadena y no es detectable con solo ver a la persona.

Escuchado las señales de infecciones de transmisión sexual.

Conocido los riesgos de tener relaciones sexo-genitales sin usar protección.

- Adquirido información sobre los métodos para evitar la transmisión de virus de la inmunodeficiencia humana (VIH) e infecciones de transmisión sexual (ITS).

Conocido cómo sí y cómo no se transmiten las ITS y el VIH y aclarado la información sobre el VIH.

\section{Conceptos clave}

ITS: Infecciones de transmisión sexual

VIH: Virus de la Inmunodeficiencia humana

\section{Bienvenida:}

Dé la bienvenida a las participantes, confirmando quiénes están presentes oausentes. Comparta con ellas que el día de hoy van a conocer sobre las Infecciones de Transmisión Sexual y el VIH/SIDA

\section{Introducción al tema:}

Pida a las participantes que hagan una lista de consecuencias de tener relaciones sexo-genitales. Apunte las consecuencias en una columna en el papelógrafo. Permita que identifiquen consecuencias de todo tipo tanto negativas como positivas. 


\section{Teorizar y definir:}

¿Qué consecuencias

positvas o negativas

pueden haber de tener

relaciones sexo-genitales?

a. El embarazo

b. Placer

c. Infección

d. VIH/SIDA

e. Cercanía con la pareja

f. Violencia, nos obligan

g. Dolor, tristeza
¿Qué medidas de

prevención se puden

tener?

Juegue con ellas la cacería de firmas. De un pedazo de papel a cada participante y dígales que todas son mujeres famosas que trabajan con éxito y son admiradas por los demás, cada una debe pensar qué hace y porqué es famosa. La meta es relacionarse entre la gente famosa y conseguir por lo menos tres firmas de otras personas famosas que están en el salón. Dé cinco minutos para que todas consigan firmas de otras tres participantes y al terminar pida que se sienten en círculo nuevamente.

Pida que la persona con el papel que tiene la estrella pase adelante y comparta que esta persona tiene una enfermedad. Cuente que la enfermedad es una infección y se transmite en su contacto con las demás personas. Pida entonces que diga quiénes le firmaron su papel y que estas pasen al frente. Pregunte:

¿Si estas tres personas están contagiadas por haber firmado el papel con la estrella, qué otras personas podrán estar infectadas también?

Pida entonces que pasen al frente las personas que firmaron el papel de esas tres y así sucesivamente hasta completar todo el grupo. Regresen al círculo y pregunte:

\section{¿Cuál fue el medio de contagio de la infección?}

¿Cómo es posible que tantas del grupo hayan terminado contagiadas por la infección?

¿Cuántas veces firmó cada una el papel de alguien más? ¿Quiénes corren el mayor riesgo de infección?

¿Cómo puede haberse prevenido la infección?

En las infecciones de transmisión sexual el mecanismo de transmisión es tener relaciones sexo-genitales sin protección ¿Cómo podrían haber evitado infectarse?

Presente un cartel con las letras ITS escritas de forma vertical y cuente que las tres forman el nombre de las enfermedades que se contagian por medio de las relaciones sexo-genitales. Pida que escriban una palabra para cada letra que describa las enfermedades que se contagian. Dé unos minutos para contestar, si no escriben lo que significa cada letra, escriba usted lo correcto, de la siguiente forma:

I nfección de

T1 ransmisión

S exual 
Usando las palabras que conforman cada letra, vaya haciendo pregunta acerca de cada palabra y permita que ellas definan qué es una ITS. Al finalizar, diga:

Estas infecciones se transmiten cuando, una persona que está infectada tienen relaciones sexo-genitales sin usar condón, transfusiones de sangre infectada (explique que cuando una persona va a donar sangre se hacen pruebas para asegurar que la sangre está bien), compartiendo agujas con sangre de personas infectadas (esto puede suceder si no se usa una aguja nueva con cada persona), de una madre infectada a su hijo o hija recién nacida, por la leche materna. Las infecciones provocan cambios en el cuerpo que son una señal de alerta para conocer que la persona está enferma.

Cuando una persona tiene una ITS sufre cambios en su cuerpo, para cada cambio que les comparta, una va a pasar al frente a señalar en estas imágenes de hombre y mujer en dónde se manifiestan los cambios.

Flujo vaginal de cualquier color con o sin mal olor.

Dolor en la parte baja del vientre.

Goteo o salida de líquido por el pene.

Picazón, ardor o molestias en el área genital o anal. Granos, llagas,

ampollas en el pene o vagina Ardor o dolor al orinar

Deficiencias en su sistema de defensas

¿Cuáles de estas señales son tan visibles que podemos identificarlas al conocer a una persona?

¿De qué forma puedo conocer si mi pareja tiene una ITS?

¿Por qué es tan importante conocer bien a mi pareja y durante un buen tiempo?

¿Qué debo hacer para cuidar mi salud, si identifico que mi pareja tiene algunas de estas señales?

Abstenerme de tener relaciones sexuales con él, hasta que se someta a tratamiento.

Recomendarle que vaya al centro de salud.

Preguntar cómo obtuvo la infección.

Ir al centro de salud para que me chequeen a mí.

¿Qué debo hacer para cuidar mi salud, si identifico que yo tengo algunas de estas señales?

Ir al centro de salud, seguir el tratamiento que me den.

Abstenerme de tener relaciones sexuales.

Informarle a mi pareja de la situación.

¿Por qué en una pareja sexualmente activa, si uno de los dos tiene estas señales, el otro debe ir a recibir tratamiento también?

Ponga junto al cartel de ITS uno que diga SIDA (también en sentido vertical) y pida a las participantes que compartan qué conocen sobre el SIDA. Llene con ellas el cartel con el significado de cada letra .

Van a jugar Mito/Verdad sobre el VIH/SIDA. Divida al salón en dos y explique que un lado es de mitos y el otro es de Verdades. Las participantes se deben ubicar en el centro de la habitación. Se leerá una oración de la hoja Mito/Ver-dades y las participantes deben correr a uno u otro lado de la habitación según crea que es lo que se les leyó. Explique la respuesta correcta y de información adicional sobre lo leído. Luego deben regresar todas al centro de la habitación para la siguiente oración. Inicie el juego y diga: 
Puedo saber si alguien está infectado con VIH de solo verlo.

Mito: una persona en el período sin síntomas se puede ver totalmente sana.

Los condones ayudan a prevenir la transmisión del VIH.

Verdadero: La mejor manera de prevenir es no tener relaciones sexo-genitales. Si las vas a tener usar el condón de forma correcta es una forma de prevención porque limita el contacto con la pareja, aunque no es $\mathbf{1 0 0 \%}$ confiable.

La persona que tiene relaciones sexo-genitales con varias parejas corre mayor riesgo de

contraer el VIH.

Verdadero: entre más relaciones sexo-genitales la persona está más expuesta y aumenta su riesgo de contraer el SIDA. Si no usa un condón al tener relaciones sexo-genitales está en riesgo de contraer todas las enfermedades tenidas por todas las personas con las que su pareja ha tenido relaciones antes.

Las personas casadas o con una sola pareja no pueden contraer el VIH.

Mito: una sola pareja no asegura que esa pareja salga con otras personas.

Puede usarse el mismo condón varias veces con seguridad.

Mito: No. Los condones solamente se pueden usar una vez.

No hay cura ni vacuna contra el VIH

Verdadero: aunque hay tratamientos para extender la vida, no hay cura ni vacuna y la persona muere con defensas muy bajas por muchas otras enfermedades.

Diga a las participantes que van a jugar memoria. Forme 4 grupos y entregue a cada uno un juego de memoria. Al recibir las tarjetas deben leer lo que éstas dicen y colocarles en desorden boca abajo sobre el suelo. Van a tomar turnos volteando las tarjetas, de dos en dos, para identificar las parejas que aparecen. Cuando una participante logra hacer una pareja debe leer al resto de su grupo qué información tienen las tarjetas y tomarlas. Luego de completar todas las parejas pida a cada grupo que haga un cartel en el que dé a conocer información sobre una de los cuatro temas siguientes. (asigne el tema a cada grupo para que todos sean cubiertos)

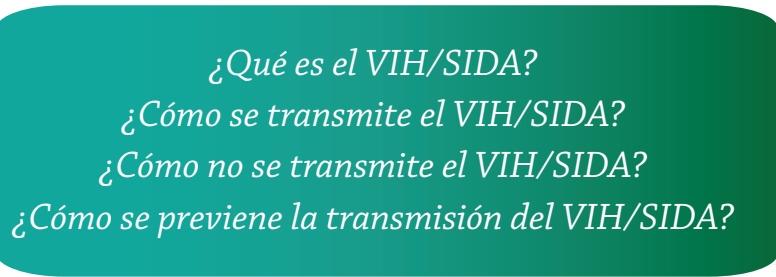

\section{Aplicación a la vida:}

Regrese al cartel con las consecuencias de las relaciones sexo-genitales y complete la columna de medidas de prevención, solicitando a cada participante que comparta una forma de prevenir alguna de las consecuencias allí identificada.

Entregue a las participantes la hoja de trabajo "Pensando en tener relaciones sexo-genitales" e invite a escribir algunas de las consecuencias de tener estas relaciones y algunos de los métodos para evitar problemas, completando al terminar la página con los pensamientos. Realizar también las hojas de trabajo “Cómo puede evitar el VIH Sida y las ITS? 

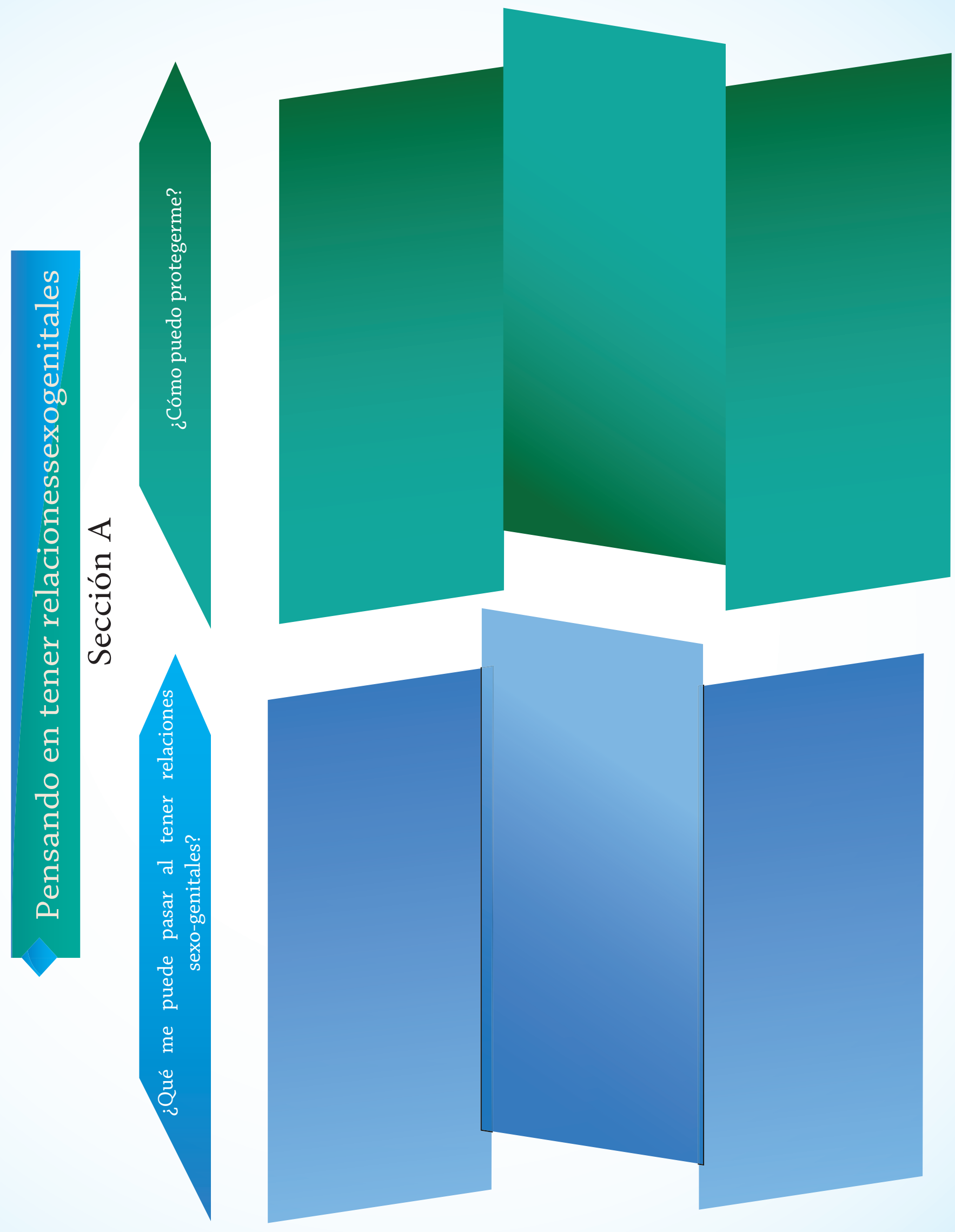


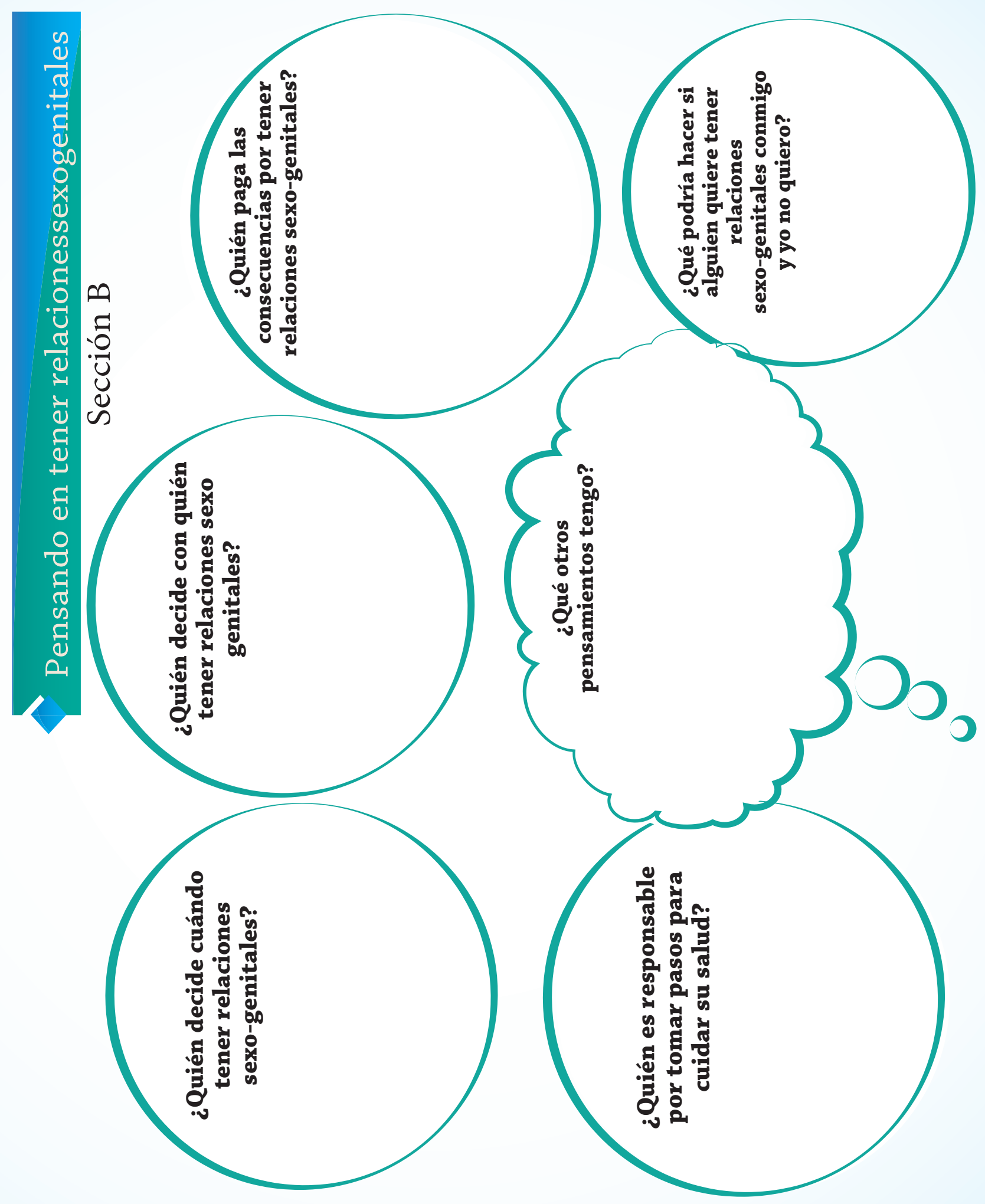



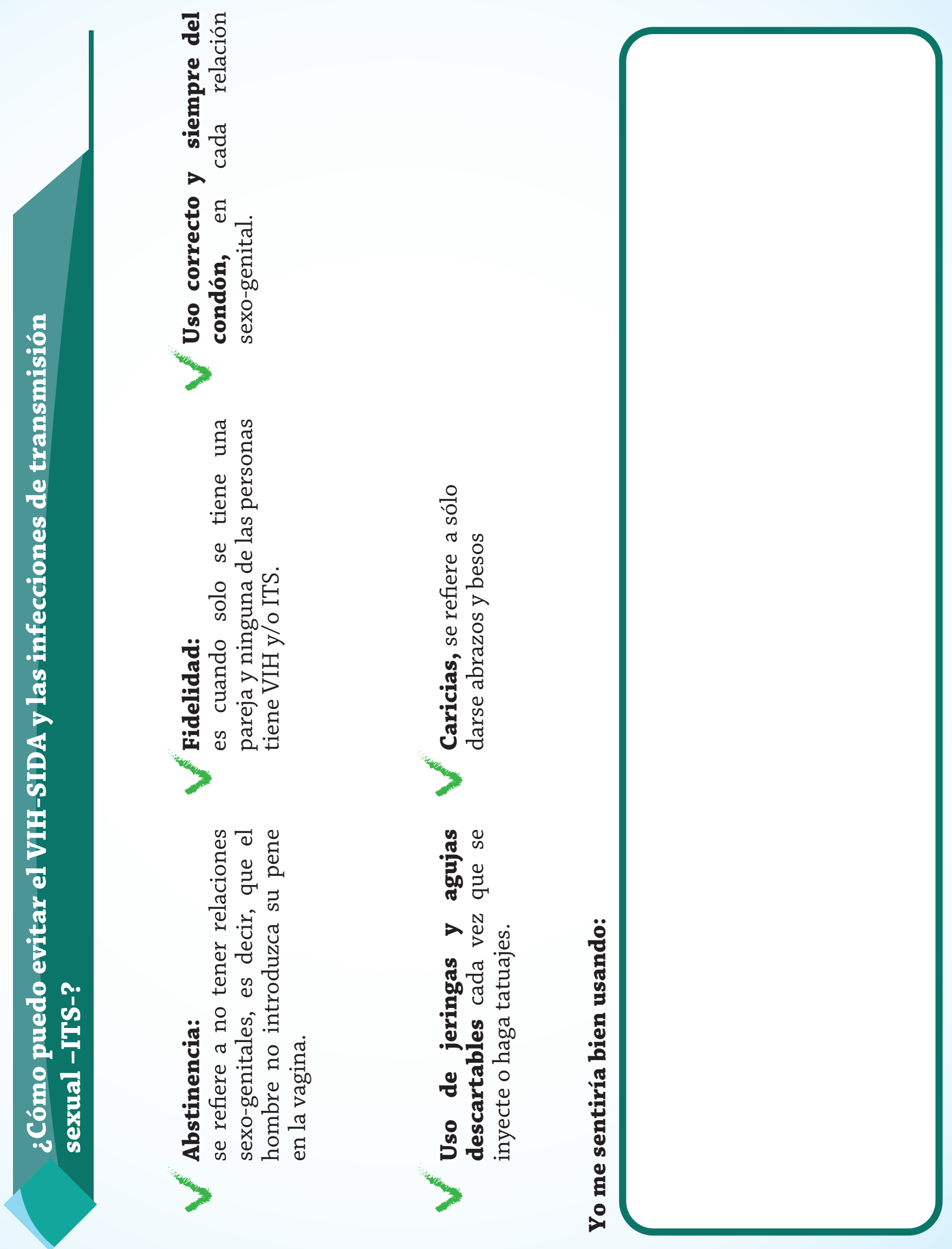


\subsection{Planificación familiar}

Al finalizar la sesión las

participantes

habrán...
- Conocido diversos los métodos e Planificación Familiar.

- Entendido las ventajas y desventajas de los diferentes métodos.

-Decidido si quieren compartir experiencias y lecciones de este tema en las comunidades

\section{Conceptos Clave}

\section{Planificación familiar:}

Cada pareja puede decidir qué tan grande quiere que sea su familia. Para ello puede usar diferentes métodos para prevenir embarazos, aumentar el tiempo entre un hijo y otro y también proteger la salud de la madre. La planificación la pueden usar mujeres y hombres que están casados, unidos o son novios. Todas las mujeres y hombres tienen el derecho de hacer la planificación familiar y que los servicios de salud les provean la información necesaria para hacerlo.

\section{Bienvenida:}

Dé la bienvenida a las participantes, confirmando quiénes están presentes o ausentes. Comparta con ellas que el día de hoy van a conocer qué es la planificación familiar y cómo se puede hacer.

\section{Introducción del tema:}

Empiece por hacer con las participantes una lluvia de ideas, escribiendo sus respuestas en un papelógrafo. Pregúnteles:

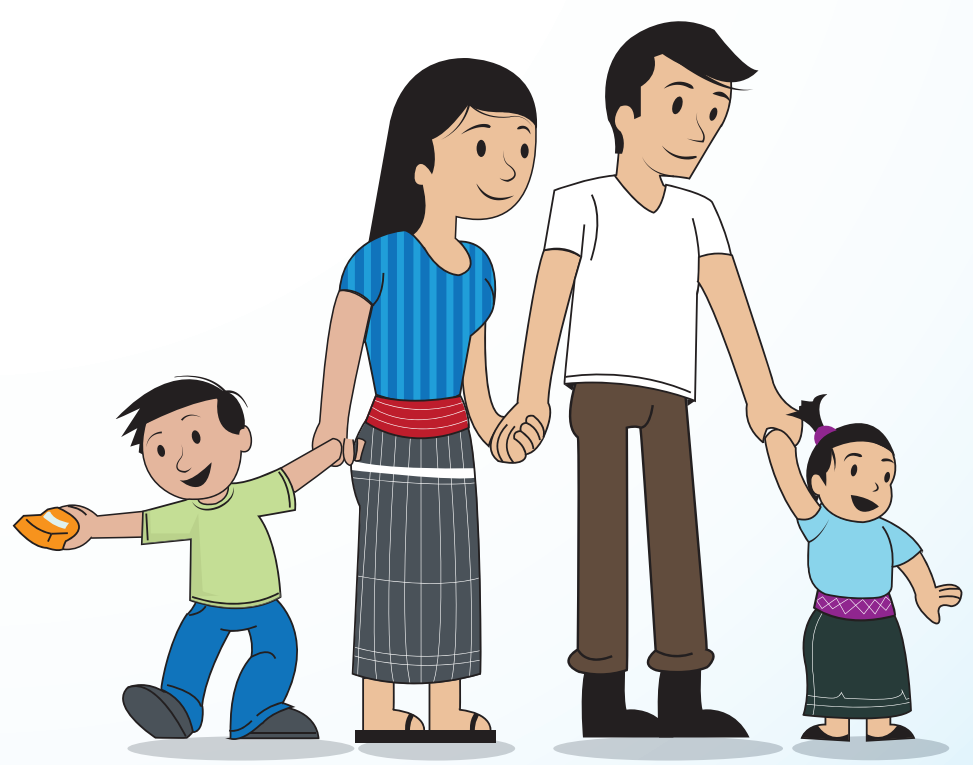




\section{¿Qué es Planificación Familiar? \\ ¿Qué métodos de Planificación Familiar -PF- han escuchado? \\ ¿Por qué es difícil platicar de la PF en las comunidades?}

\section{Teorizar y definir:}

Divida a las participantes en grupos. Cada grupo va tener un método de planificación familiar y va a hacer una dramatización interpretando una pareja buscando un método anticonceptivo en un centro de salud. Dos personas pueden ser la pareja y el resto trabajadores del centro de salud. El grupo tiene que incluir información de su método, si es natural o no y las ventajas y desventajas de su uso.

Permita que hagan las dramatizaciones y luego de cada una, la mentora de grupo retoma lo más importante sobre el método que se conoció.

Al terminar lean el folleto de UNFPA "Planificar para lograr la equidad" y la hoja de contenido de métodos de planificación familiar.

Demostrar paso a paso cómo se coloca y retira un condón.

\section{Aplicación para la vida:}

Platique con las participantes que a veces por una u otra razón las jóvenes de la comunidad se casan a temprana edad y quedan embarazadas. Las dos cosas juntas afectan mucho sus posibilidades de alcanzar sus planes. Por lo menos si se casan pueden buscar la forma de prevenir un embarazo con los métodos anticonceptivos. Entregue la hoja de trabajo “Tener un hijo/a antes de los 20" y pídales escribir tres formas de prevenir que esto suceda. Pueden luego leer la Hoja de Contenido: Métodos anticonceptivos y usar la información para completar el ejercicio "Métodos" escribiendo en cada espacio el que más les llama la atención y marcando su accesibilidad pintando las estrellas de la siguiente forma.

1 estrella $=$ No es accesible porque es caro, no sé dónde puedo ir para encontrarlo, no me gusta este método

2 estrellas = El método no es malo, pero tampoco es bueno para mí.

3 estrellas $=$ Este método me parece fácil de usar, conseguir y lo usaría.

Al terminar de marcar los métodos con las estrellas, pregunte ¿A qué metodos anticonceptivosles para les dieron dos o tres estrellas? y anótelos en una papelógrafo y pregunte ¿dónde podrían conseguirlos? y ¿dónde pueden obtener información sobre ellos? -pida que la información la anoten en su hoja de trabajo- 


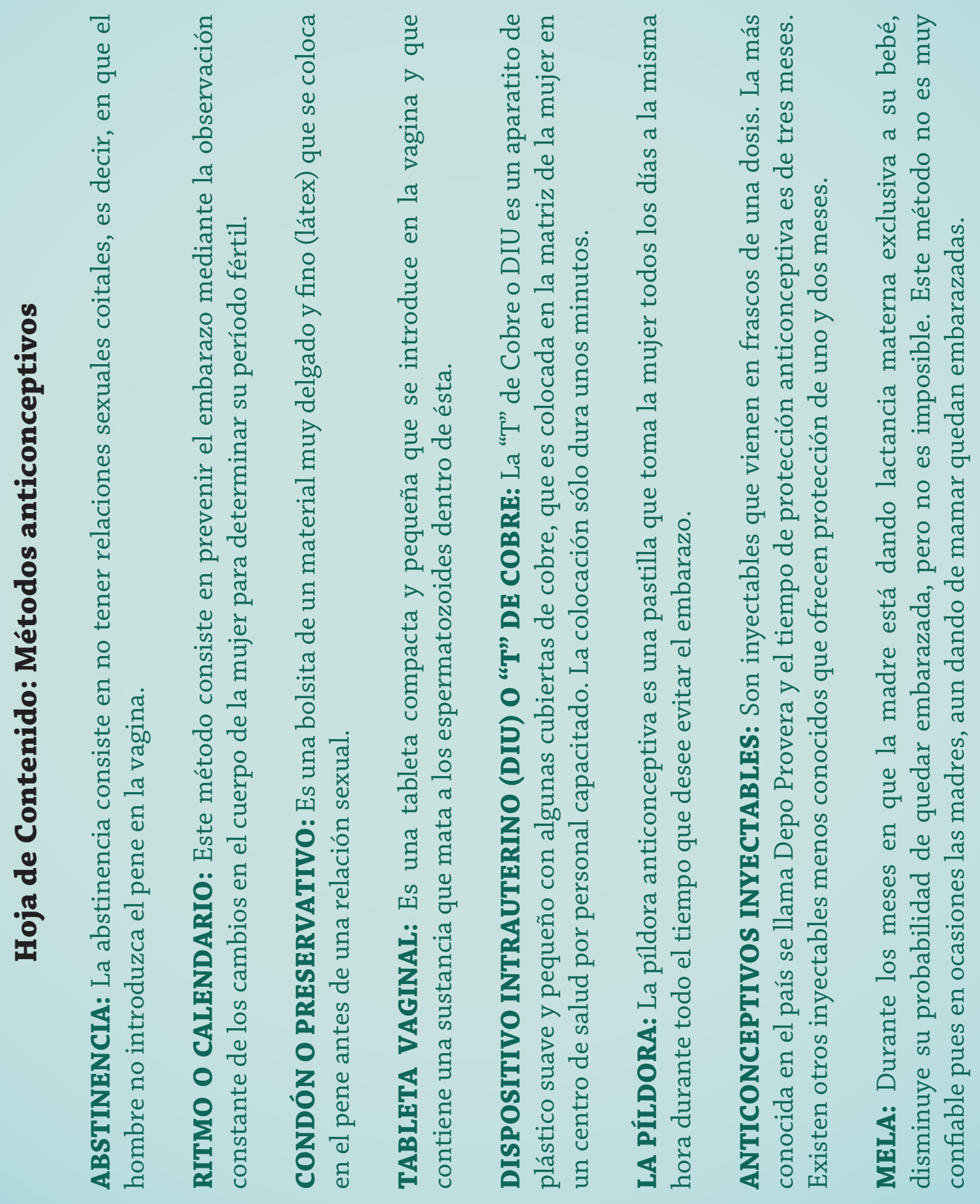




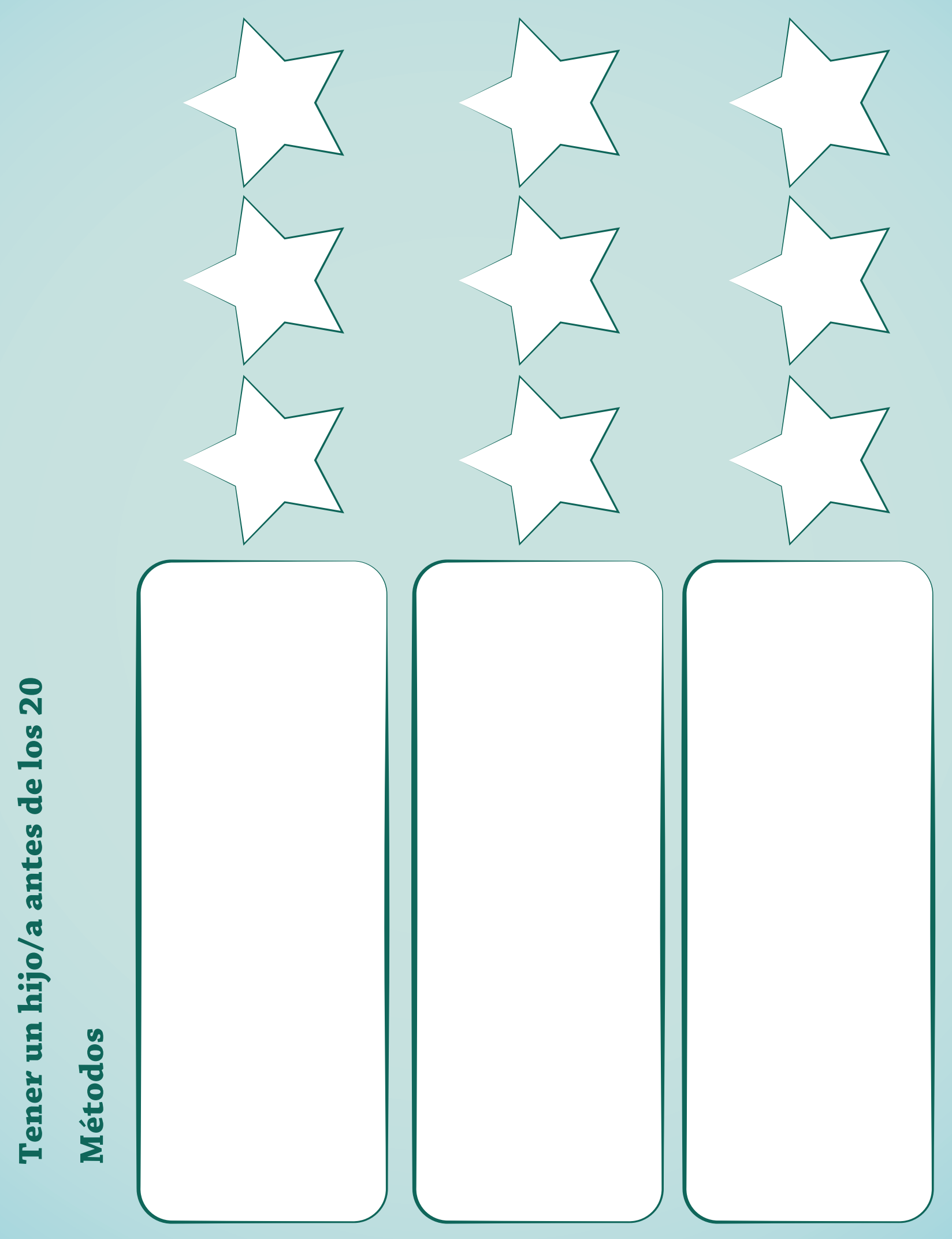




\subsection{Soy un aporte para el desarrollo}

\section{2 horas}

Al finalizar

la sesión las

participantes

habrán...
Comprendido qué es el desarrollo humano y cómo se alcanza.

Hecho su plan de vida considerando sus metas personales y lo que pueden aportar a su comunidad.

Sugerido acciones que pudieran realizarse dentro de su comunidad para mejorar el desarrollo humano.

\section{Concepto Clave}

\section{Desarrollo humano:}

Considera la calidad de vida de las personas, que siempre debiera ir en constante mejora.

Identifica la calidad de vida según el grado educativo, los ingresos y los años que viven las personas en una comunidad, municipio, departamento, país.

Tarea de a sesión 5.6 entregada por las participantes en el trimestre anteriol

\section{Recursos de apoyo:}

It's All One Curriculum Actividad 53 Frases inspiradoras jpara el cambio!

Salud y empoderamiento Actividad 7 y Actividad 9

\section{Bienvenida:}

Dé la bienvenida a las participantes, confirmando quiénes están presentes o ausentes. Comparta con ellas que el día de hoy van a identificar lo valiosa que puede ser cada una para el desarrollo humano de su comunidad.

Empieza por el reconocimiento ęodas de las cualidades y fortalezas que tienen que puedan aportar al desarrollo de la comunidad con el juego "Las botella de las cosas Buenas". Siente a las participantes en un círculo y coloque en el centro una botella. Pida a alguna que empiece por girarla y que cuando la botella se detenga le va a decir a la compañera a la que señale la botella una cualidad/fortaleza y cómo puede aportar al desarrollo de la comunidad. Luego ella hará el ejercicio, hasta que pasen todas y a todas se les diga una cualidad/fortaleza. 


\section{Introducción del tema:}

Devuelva los trabajos de la sesión 5.6 a cada una y pida que de forma individual los lean y subrayen una cosa que les motiva mucho a trabajar por la comunidad, de lo que la persona entrevistada les haya dicho.

Se juntarán en grupos de cuatro y cada una contará las respuestas de las preguntas que hizo y contará sobre la persona a la cual se acercó. Mientras comparte, todas deberán escucharla con atención e identificar frases o palabras que les llamaron la atención. Al finalizar cada grupo deberá escoger y escribir una frase que les inspira a trabajar por su comunidad y escribirla en un papelógrafo. Estas pueden ser creadas entre ellas a partir de los escuchado o copiadas literalmente de las respuestas compartidas.

Todos los grupos presentarán sus frases y explicarán porqué escogieron esa frase. Motive a la conversación sobre el compromiso con la comunidad y cómo al aportar a la comunidad se abren oportunidades para una también, pregunte:

¿Qué han aprendidode las personas que entrevistaron y las frases?

¿Cómo ha cambiado la comunidad gracias al trabajo de estas personas?

¿Qué cosas creen que podrían hacer ustedes?

¿Qué sentimientos expresaron estas personas que tienen sobre su vida?

¿Qué cosas pueden hacer estas personas hoy que no hubieran podido hacer antes de empezar a trabajar por la comunidad.

\section{Teorizar y definir:}

Lean la definición de Desarrollo Humano que está en los conceptos clave y recuerden cuáles son las metas del milenio que más les habían interesado. Piensen que ellas son ahora responsables de aportar a alcanzar las metas y mejorar el desarrollo en su comunidad.

Haga con las participantes una lista de todas las cosas que han aprendido desde que están en Abriendo Oportunidades que pueden servirles para alcanzar el desarrollo humano, apunte sus respuestas en un papelógrafo y úselas para la siguiente actividad, pregunte: 
¿Qué cosas han aprendido en Abriendo Oportunidades?

\section{Trabajar en el campo}

Cuidar a los niños de su familia

Ayudar en las tareas de la casa

Negociar para que las dos partes ganen

Reconocen sus derechos humanos

Saben cuidar la autoestima en otras mujeres

Se pueden comunicar asertivamente para defenderse

Contactan y se comunican con líderes de la comunidad

Como ayudar a una mujer embarazada a identificar signos de riesgo

Prevenir el VIH/SIDA

Forma de tomar decisiones

Pueden cambiar de conflictos en habilidades

Trabajar en equipo con otras mujeres

Cuidarme y a otras mujeres en la comunidad

\section{Aplicación para la vida}

Pida a cada participante que de forma individual escoja una de las cuatro frases que le inspiran a trabajar para el desarrollo de la comunidad y en una hoja de papel haga un dibujo, canción, poema...de cómo sería su vida si aplica esa frase a todo lo que hace. Recuérdeles que incluyan en su vida la meta a la que quieren colaborar en la comunidad. Pida que en la parte de atrás del dibujo escriban:

- Pasos a seguir para lograr esa vida

- Cosas a fortalecer en mi vida

- Mi aporte a la comunidad

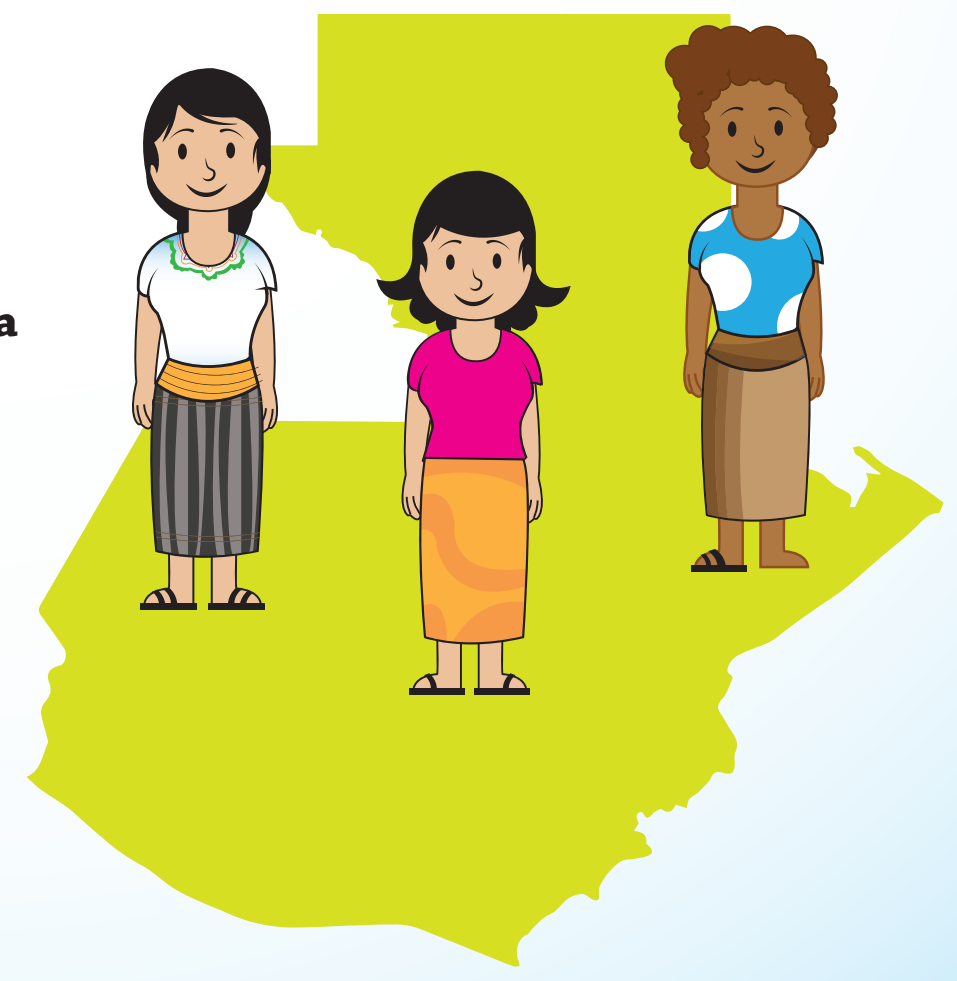


Al finalizar

la sesión las

participantes

habrán...
Identificado las ventajas y retos de la decisión que tiene que tomar en su vida para aportar a la comunidad y desarrollarse.

Preparado una presentación de su trabajo a la comunidad que les ha apoyado.

\section{Bienvenida}

Recuerde con las participantes todos los temas que han estudiado y aprendido en las sesiones. Diga: Hemos aprendido temas importantes para la vida de mujeres y niñas en esta comunidad, cosas sobre derechos humanos, género, salud de la mujer, finanzas etc. Todos los temas son parte de la vida diaria de nosotras y de otras personas, pregunte:

Lista con temas de impacto social Hojas para escribir

\section{¿Qué temas les llamaron más la atención?}

Anote las respuesta en un papelógrafo, revisela y relaciona con el papelógrafo que tiene la lista de temas de impacto social que hemos trabajado en las sesiones, después diga: van a tomarse un momento para escoger tres temas de la lista que les interese mucho, les importe y los van a anotar en la hoja que les acabo de entregar.

\section{Temas en la lista...usted puede ampliar o cambiar según la situación de su comunidad:}

\section{Presión social por casarse a temprana edad}

- Falta de oportunidades de educación a partir de básicos

Autoestima baja en mujeres y niñas de la comunidad

- Violencia y rivalidad entre mujeres

- Violencia en contra de las mujeres

- Riesgos de infecciones de transmisión sexual

- Incumplimiento a derechos sexuales de las mujeres

- Acceso de métodos anticonceptivos

- Conflictos históricos de la comunidad que necesitan ser solucionados

- Lugares peligrosos no seguros para mujeres en la comunidad

- La discriminación a mujeres, indígenas, jóvenes

- Derecho a la alimentación en las familias de la comunidad

- Trabajos riesgosos para las mujeres y jóvenes

- Las responsabilidades que imponen a las mujeres y no pueden desarrollarse 


\section{Introducción al tema:}

Pida que se reúnan en parejas y con su pareja compartan cuáles son los temas que les importan más, por qué les interesa ese tema, alguna historia personal que se relaciona con el tema.

Regrese a plenaria y permita que algunas compartan los temas que les importan con todo el grupo. Introduzca el tema de trabajar para el cambio social, mediante acciones concretas. Empiece por explorar campañas que se han hecho a nivel mundial y nacional y luego pase a platicar de acciones hechas a nivel local dentro de la comunidad. Diga:

Algunas personas se involucran en grandes campañas para provocar cambio social, pregunte:

\section{¿Pueden mencionar algún caso?}

¿Conocen acciones que trabajan en el tema de salud sexual y reproductiva, género y equidad?

¿Qué cambios habrán provocado estas acciones?

\section{A veces las acciones pequeñas también logran generar cambios, acciones que se hacen en tu} propia vida y la vida de tu familia y comunidad.

¿Qué acciones podrán desarrollar en su comunidad, familia y vida para provocar cambio en esos temas que te importan?

¿Qué riesgos puede correr una persona al trabajar por el cambio social en estos temas que has escogido?

Escribir una pequeña redacción para presentar a familia y miembros de la comunidad de su experiencia, dando respuesta a las preguntas:

¿Qué tema te interesa?

¿Cómo afecta este tema tu vida y la de la comunidad?

¿Qué puedes hacer para el cambio social en este tema?

\section{Teorizar y definir:}

Díga a las participantes que harán una sesión de clausura en la que presentarán el trabajo que han hecho y sus planes de vida a sus familias, líderes comunitarios y las personas que les han apoyado durante el curso. Calendarize la fecha de la sesión con ellas. Tome un par de semanas para preparase, invitar a familia y líderes a la actividad.

Empiece por hacer con las participantes listas de lo siguiente:

1. Personas que quieren invitar a la actividad.

2. Cosas que les quieren presentar.

3. Ideas y metas que quieren compartir 
Presente una posible agenda de la reunión, hágala con ellas y decidan juntas quiénes quisieran encargarse de la preparación y presentación de los diferentes puntos. Asegúrese que todas las participantes tengan algo importante que hacer en la sesión, ya sea hablar en la bienvenida, confirmar la asistencia de los invitados, presentar alguno de los puntos de la agenda, preparar los materiales, manualidades $y$ trabajos que van a exponer. Algunos puntos pueden ser

$\checkmark$ Bienvenida a los /las invitados

$\checkmark$ Presentación de qué es Abriendo Oportunidades

$\checkmark$ ¿Cómo Abriendo oportunidades cambió mi vida?

$\checkmark$ Queremos contribuir a la comunidad con lo que hemos aprendido en abriendo oportunidades

$\checkmark$ Lo que producimos en abriendo oportunidades

Queda de tarea para cada una prepararse, escribir sus palabras, encontrar sus manualidades, hablar con las personas que les toca invitar etc. En la siguiente sesión aproveche para hacer ensayo con ellas y que preparen todo lo que necesitan para la reunión de cierre.

Al llegar la fecha, realice lo que ha acordado con las participantes. Al finalizar el acto puede entregar un diploma a las participantes por su participación. Permita que los invitados pasen a ver la exposición de manualidades y trabajos hechos por las participantes.
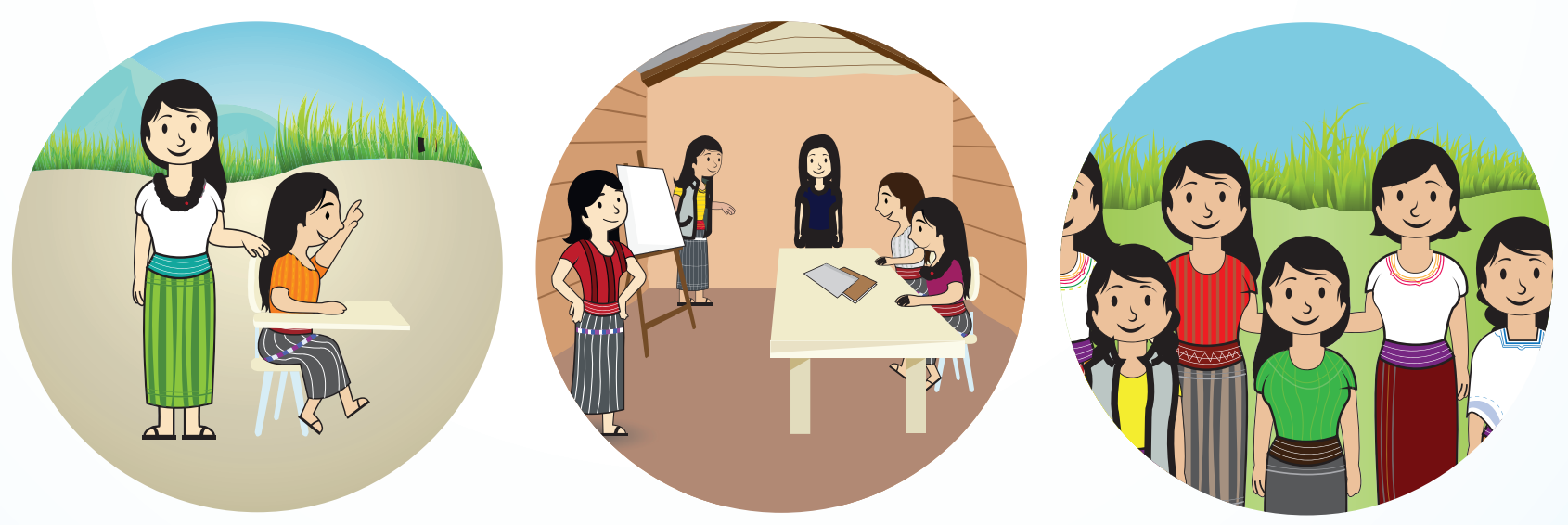


\section{Bibliografía}

Asantení. (2006). Financial Literacy Education. Kibera: Financial Education From Poverty to Prosperity.

Asociación Guatemalteca de Mujeres Médicas. Rompamos el Silencio. Guatemala.

AVON. No estás sola existe una salida queremos ayudarte. Guatemala: AVON.

CICAM. (2005). Política de salud para la adolescencia y la juventud. Guatemala: CICAM.

CICAM. Vamos a darle vuelta al mundo. Guatemala.

COEPSIDA. (1998). Salvar una vida, la tuya Vida o Sida. Guatemala.

Congreso de la República de Guatemala. (2000). Decreto Número 27-2000 Ley General para el combate del VIH y del SIDA y de la promoción, protección y defensa de los derechos humanos ante el VIH/SIDA. Guatemala: MSPAS.

CONJUVE, UNFPA. La Violencia Mata al Amor Detenla. Guatemala: Fundación Sobrevivientes.

Cuerpo de Paz Guatemala. (2009). Taller Acerca del VIH/SIDA Guía para facilitadores. Santa Lucía Milpas Altas.

Fundación Sobrevivientes. Medidas de seguridad ciudadana para mujeres. Guatemala: Fundación Sobrevivientes.

Fundación Sobrevivientes. Abordaje en Violencia Sexual. Guatemala: Fundación Sobrevivientes.

Instituto Mexicano de Investigación de Familia y Población. La Violencia Doméstica. México D.F.: IMIFAP.

International Sexuality and HIV Curriculum Working Group. (2009). It's All One Curriculum: Guidelines and Activities for a Unified Approach to Sexuality, Gender, HIV and Human Rights Education. Nueva York: Population Council.

Ministerio de Salud Pública y Asistencia Social. La Ovulación. Guatemala: MSPAS.

Ministerio de Salud Pública y Asistencia Social. Memoria Juego Educativo para la prevención del VIH/SIDA . Guatemala: MSPAS, OPS, ASDI.

Ministerio de Salud Pública y Asistencia Social. (2010). Plan de acción para la reducción de la mortalidad materna neonatal y mejoramiento de la salud reproductiva. Guatemala: MSPAS.

ODHAG. Guía sobre la transformación de conflictos. Guatemala, Guatemala: ODHAG. 
Organización de las Naciones Unidas. (1998). Declaración Universal de los Derechos Humanos. Guatemala: UNESCO.

Population Council. Rotafolio Métodos para el espaciamiento de embarazos. Guatemala: Population Council Información Educación y Comunicación.

Procurador de los Derechos Humanos. Guía de Orientación para víctimas de violencia intrafamiliar. Guatemala: PDH.

Programa de Desarrollo Integral Comunitario. (2003). Alimentación y Empoderamiento (Manual de Ejercicios y Rotafolio). México: IMIFAP-Educación, Salud y Vida.

Programa de Desarrollo Integral comunitario. (2003). Salud y empoderamiento (manual de ejercicios). México D.F.: IMIFAP-Educación, salud y vida.

Una Voz Contra el Cáncer. Tómatelo a pecho cuídate. Guatemala: American Cancer Society.

UNFPA. (2007). Planificar para lograr la equidad. Guatemala: UNFPA. 
